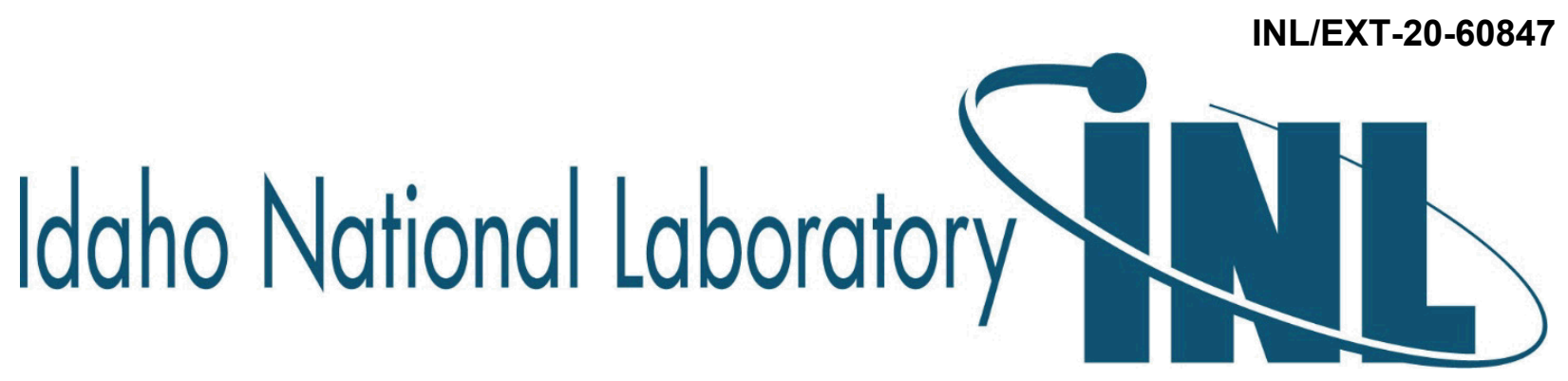

\title{
Permanent Closure of the TAN-680 Diesel Underground Storage Tank 98TAN00650 (DEQ Facility ID\# 6-120618)
}

December 2020

Idaho National Laboratory Idaho Falls, Idaho 83415

http://www.inl.gov

Prepared for the

U.S. Department of Energy

Office of Nuclear Energy

Under DOE Idaho Operations Office

Contract DE-AC07-05ID14517 


\section{DISCLAIMER}

This information was prepared as an account of work sponsored by an agency of the U.S. Government. Neither the U.S. Government nor any agency thereof, nor any of their employees, makes any warranty, expressed or implied, or assumes any legal liability or responsibility for the accuracy, completeness, or usefulness, of any information, apparatus, product, or process disclosed, or represents that its use would not infringe privately owned rights. References herein to any specific commercial product, process, or service by trade name, trade mark, manufacturer, or otherwise, does not necessarily constitute or imply its endorsement, recommendation, or favoring by the U.S. Government or any agency thereof. The views and opinions of authors expressed herein do not necessarily state or reflect those of the U.S. Government or any agency theref. 


\section{CONTENTS}

1. PURPOSE

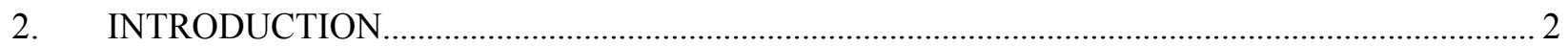

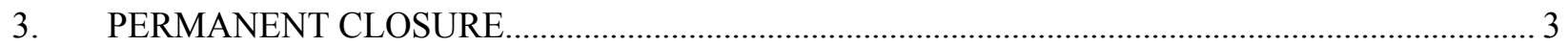

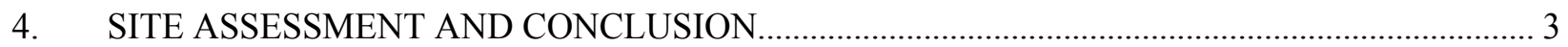

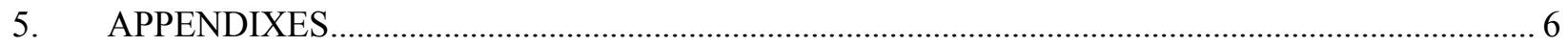

Appendix A, CCN: 243516 Temporary Closure - 30 Day Notification for Underground Storage Tank Systems - Test Area North (DEQ Facility ID\# 6-120618) ........................

Appendix B, CCN: 247669 - Permanent Closure - 30 Day Notification for Underground Storage Tank Systems - Test Area North (DEQ Facility ID\# 6-120618)......................13

Appendix C, - TAN UST Removal TOS-302 Sampling Logbook ........................19

Appendix D - UST Removal TOS-302 Sampling Event Narrative Test Area North

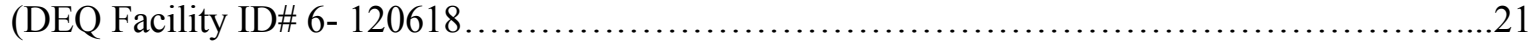

Appendix E - Sample Analytical Report TOS-302 Gel Laboratories Data Package... .............32

\section{FIGURES}

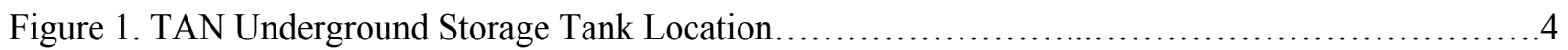

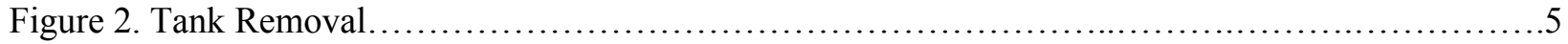

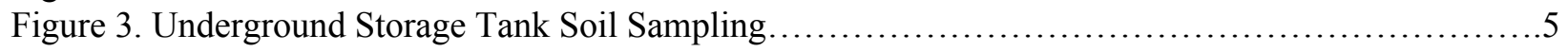

TABLES

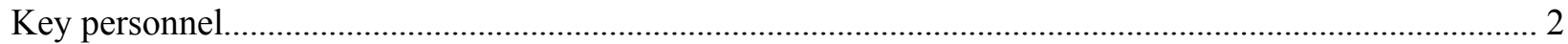




\section{PURPOSE}

This closure package documents the site assessment and petitions for permanent closure of the Idaho National Laboratory (INL) Test Area North (TAN) diesel underground storage tank 98TAN00650 (DEQ Facility ID\# 6120618), in accordance with the regulatory requirements established in 40 CFR 280.71, "Permanent Closure and Changes-In-Service".

\section{INTRODUCTION}

The TAN diesel underground storage tank 98TAN00650 is a 15,000-gallon; double-walled, fiberglass reinforced plastic tank located at the Idaho National Laboratory's (INL) Test Area North, TAN-680. This tank is identified under the Idaho Department of Environmental Quality (DEQ) Tank Management Plan facility identification number 6-120618.

The tank was installed in 1991 to supply diesel fuel for bus and vehicle operations. The tank was manufactured by Xerxes Corporation and the dimensions of the tank are 10' 4" diameter by 29' 5" in length. The tank was monitored by a Gilbarco Veeder-Root TLS-350 Automatic Tank Gauge (ATG). The tank monitoring included Continuous Statistical Leak Detection (CSLD), an interstitial sensor, and a transition sump sensor. The piping from tank to the transition sump is fiberglass reinforced pipe. Piping from the transition sump to the dispenser is above ground carbon steel. The piping run is safe-suction.

Key personnel that were involved in this closure activity are listed in Table 1.

Table 1. Key personnel.

\begin{tabular}{lll}
\multicolumn{1}{c}{ Organization/Title } & \multicolumn{1}{c}{ Name } & \multicolumn{1}{c}{ Responsibilities } \\
\hline BEA Project Manager & Herbert A. Pollard III & Project execution and completion \\
\hline BEA Project Supervisor & Eric Walker & Project execution and completion \\
CFA Facility Manager & Bryan Crofts & Manage/approve facility activities \\
BEA Environmental Compliance & $\begin{array}{l}\text { Bradley Griffith/Brian } \\
\text { Donovan/Kerry Nisson }\end{array}$ & Coordinate UST closure activity \\
Sampling Personnel & Joanna Taylor/Tylor & Environmental Sampling \\
& Johnson/Jonah Davis &
\end{tabular}




\section{PERMANENT CLOSURE}

In accordance with 40 CFR 280.71(a), a 30-day closure notification was e-mailed on September 9, 2020, (Appendix B, CCN 247669) notifying DEQ of INL's intent to permanently close the 98TAN00650 diesel underground storage tank (DEQ ID\# 6-120618). Michael Summers (DEQ) was contacted regarding a sampling and analysis plan. Michael stated that a sampling and analysis plan would not be required.

On November 18, 2020, a conference call was placed to Michael Summers at the DEQ Idaho Falls Office, informing him of INL's intent to remove the UST and to identify if DEQ wanted to be present during any part of the removal process. Michael stated that he wanted to be present during the tank removal and sampling process. It was stated that INL would contact him when an exact date was confirmed or $\square$ to any delays. Michael also emailed three documents for use in sampling process:

1. Fact Sheet: "How DEQ Evaluates Sample Collection and Data Analysis for UST Closures and Release Investigations"

2. Table 1 "Chemicals of Interest for Various Petroleum Products" and Table 2 "Residential Use Screening Levels" from IDAPA 58.01.24 - Application of Risk Based Department of Environmental Quality Corrective Action at Petroleum Release Sites

3. Table 2. "Screening Level Concentrations for Soil, Groundwater, and Soil Vapor" from Risk Evaluation Manual for Petroleum Releases-August 2018

The tank was placed in temporary closure status in October 2108 after the tank was drained to less than oneinch of product (including piping), the vent lines remained open and functioning, all lines were capped and secured, and the fill pipe was padlocked shut.

On October 2, 2018, the INL notified the DEQ that this tank met the temporary closure requirements and sent a "Notification for Underground Storage Tank Systems" form to place the tank in temporary closure status (Appendix A - CCN: 243516, Temporary Closure of UST at Test Area North).

On November 23, 2020, the UST at TAN-680 was removed with Michael Summers (DEQ) in attendance. INL's Environmental Monitoring personnel collected three soil samples from under the tank (one at each end of tank and one in the middle) and one sample from under the transition sump (end of piping run). Soil samples were sent to GEL Laboratories LLC in Charleston, South Carolina for analysis. Laboratory analysis was requested for Chemicals of Interest for Various Petroleum Products (diesel) as identified in IDAPA $\square$ 58.01.24.800.01 $\square$ table 1, with laboratory detection limits for the Residential Use Screening Levels identified in IDAPA 58.01.24.800.02 table 2. The sampling collection and handling process adhered to the "Waste Management and Remediation Division Statewide Generic Quality Assurance Plan".

On December 12, 2020, Joanna Taylor from INL Environmental Monitoring e-mailed the sampling data package received from GEL Laboratories LLC. The preliminary sampling data showed that the screening levels for the Chemicals of Interest for Various Petroleum Products (diesel) as identified in IDAPA $\square$ 58.01.24.800.01 $\square$ table 1, were below the Residential Use Screening Levels as identified in IDAPA 58.01.24.800.02 table 2 and below the Screening Level Concentrations for soil in Table 2 of the "Risk Evaluation Manual for Petroleum Releases".

\section{SITE ASSESSMENT AND CONCLUSION}

This site assessment was performed in accordance with IDAPA 58.01.24.200, "Risk Evaluation Process." A screening evaluation was performed according to the chemicals of interest for diesel fuel found in the Idaho Risk Evaluation Manual for Petroleum Releases, Table 2 - Screening Level Concentrations for Soil, Groundwater, and Soil Vapor and sample results were below the Screening Level Concentrations for soil from Table 2 of the "Risk Evaluation Manual for Petroleum Releases". 
Per 40 CFR 280.71 "Permanent Closure and Changes-In-Service" all liquids and accumulated sludge were removed from the UST. Sample results were received on December 12, 2020 and were compared to the "Idaho Risk Evaluation Manual for Petroleum Releases", Table 2 - Screening Level Concentrations for Soil, Groundwater, and Soil Vapor maximum media-specific (soil) petroleum contaminant concentrations. The concentrations for the chemicals of interest are below the DEQ identified screening levels for these analytes.

According to IDAPA 58.01.24.200.01.c., "if the maximum media-specific petroleum contaminant concentrations at the site do not exceed the screening levels, the owner and/or operator may petition for site closure, subject to other Department regulatory obligations". This site assessment meets the requirements of IDAPA 58.01.24.200. The INL is petitioning the DEQ for site closure of the TAN-680 diesel tank 98TAN00650 (DEQ ID\# 6-120618).

Figure 1. TAN Underground Storage Tank Location

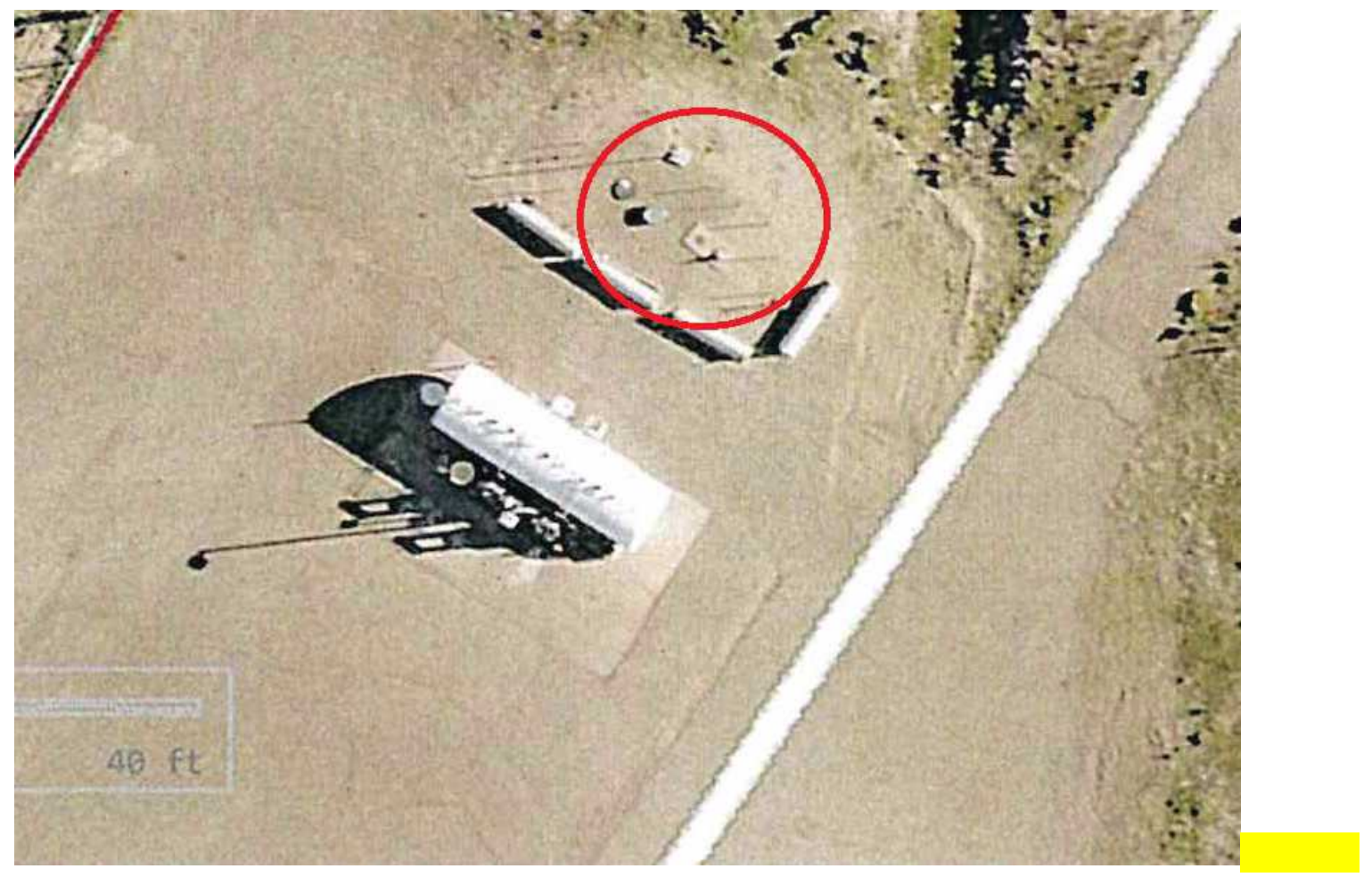


Figure 2. Tank Removal

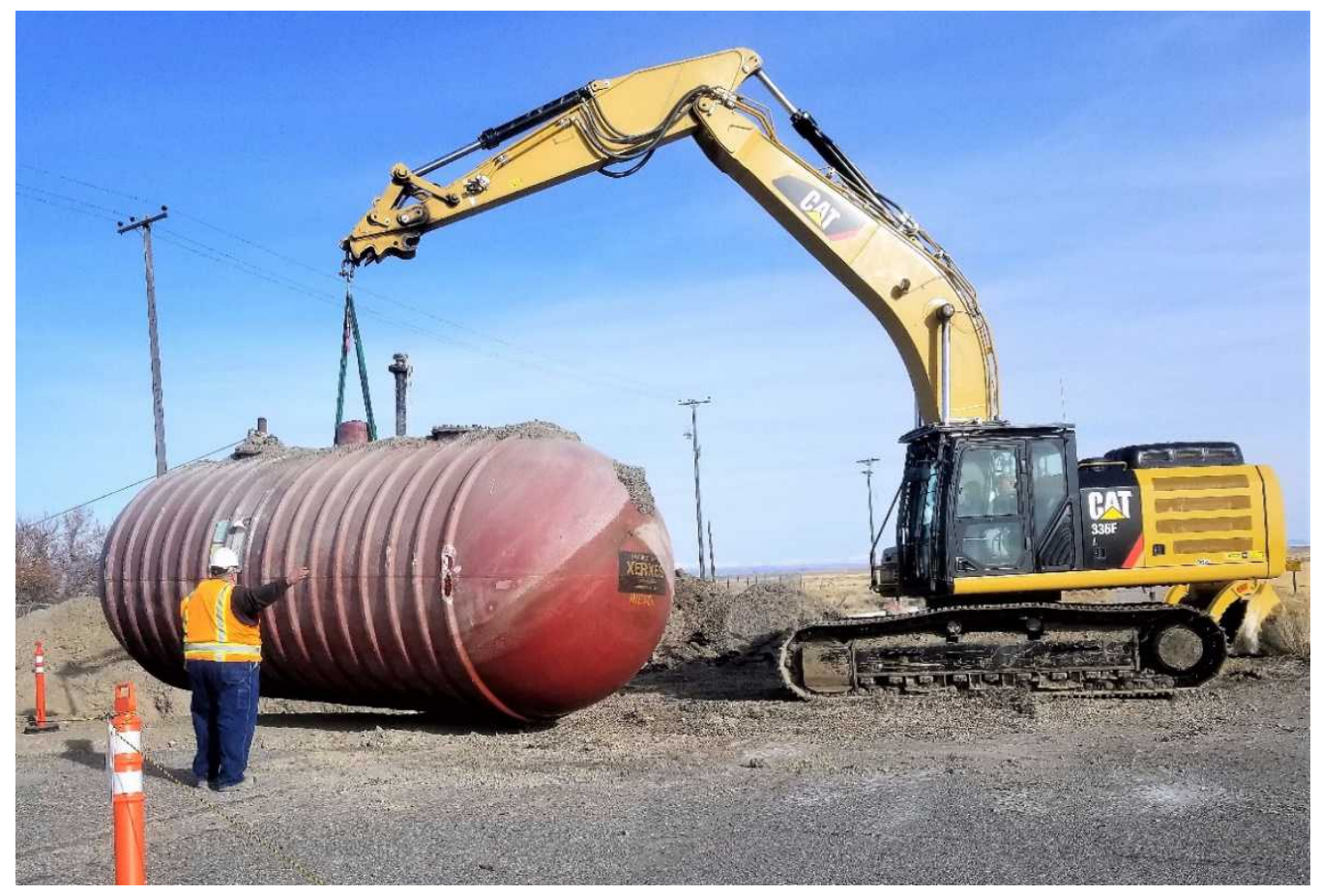

Figure 3. Underground Storage Tank Soil Sampling

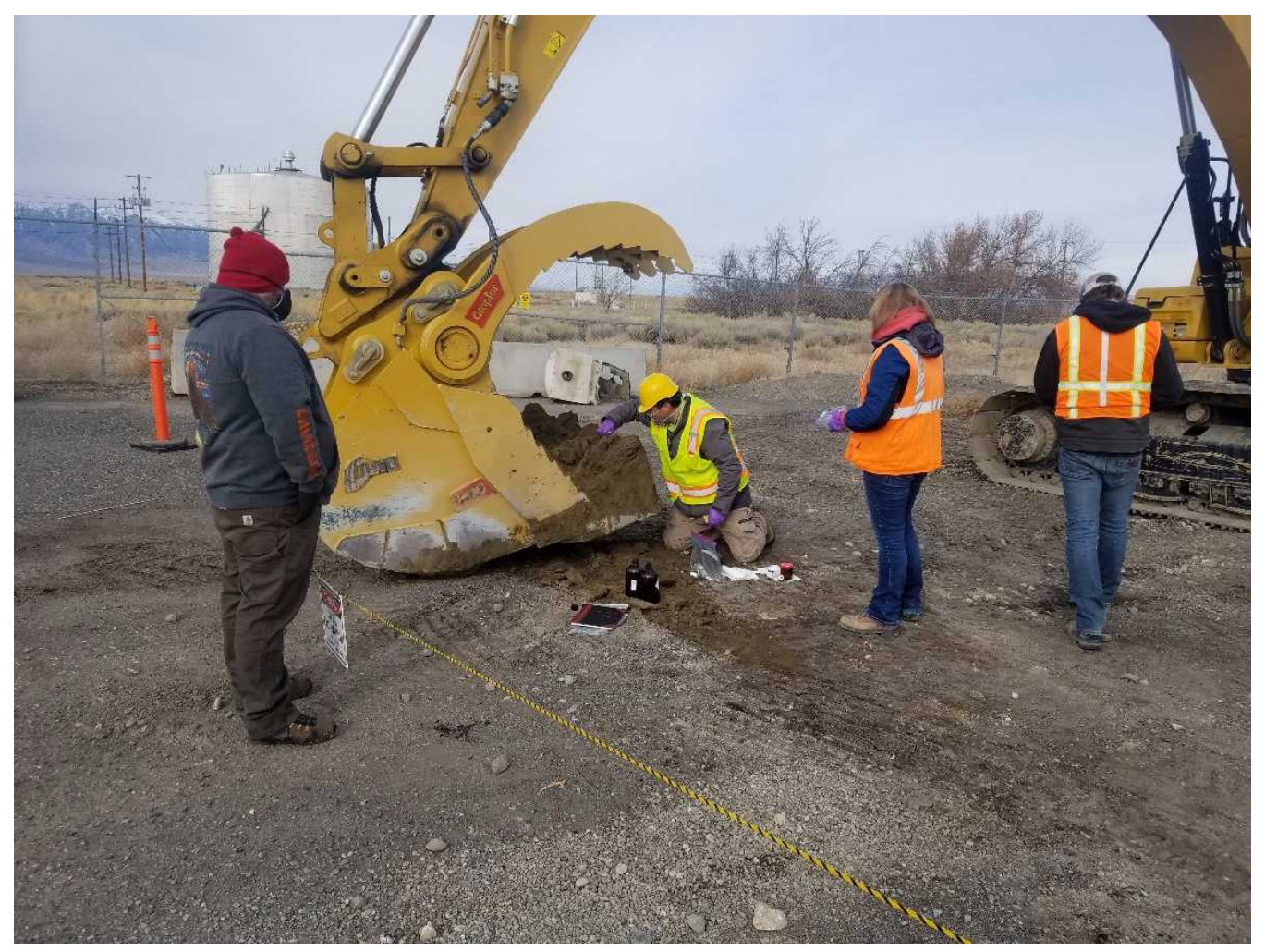




\section{APPENDIXES}

Appendix A, CCN: 243516 Temporary Closure - 30 Day Notification for Underground Storage Tank Systems Test Area North (DEQ Facility ID\# 6-120618)

Appendix B, CCN: 247669 - Permanent Closure - 30 Day Notification for Underground Storage Tank Systems - Test Area North (DEQ Facility ID\# 6-120618)

Appendix C, - TAN UST Removal TOS-302 Sampling Logbook

Appendix D - UST Removal TOS-302 Sampling Event Narrative Test Area North (DEQ Facility ID\# 6120618

Appendix E - Sample Analytical Report TOS-302 Gel Laboratories Data Package 


\title{
Appendix A, CCN: 243516 Temporary Closure - 30 Day Notification for Underground Storage Tank Systems - Test Area North (DEQ Facility ID\# 6-120618)
}

Mail - lauralee.gourley@inl.gov

Page 1 of 1

\section{CCN: 243516 Temporary Closure of UST at Test Area North}

\author{
Kerry L. Nisson \\ Tue 10/2/2018 2:27 PM \\ Tomichael.summers@deq.idaho.gov <michael.summers@deq.idaho.gov>; \\ Cc:Nicole K. Hernandez <hernannk@id.doe.gov>; Bradley K. Griffith < bradley.griffith@inl.gov>; Kent L. Miller \\ <kent.miller@inl.gov>; Bryan P. Crofts <bryan.crofts@inl.gov>; George J. Krauszer II <george.krauszerii@inl.gov>; James \\ F. Graham<james.graham@inl.gov>; Timothy A. Miller<timothy.miller@inl.gov>; Carlo D. Melbihess \\ $<$ Carlo.Melbihess@inl.gov >; Dwight S. Stevenson < dwight.stevenson@inl.gov >; BEA CORRESPONDENCE CONTROL \\ $<$ beacc@inl.gov>; ENVIRONMENTAL CORRESPONDENCE <envaff@inl.gov>; LauraLee Gourley \\ $<$ lauralee.gourley@inl.gov>; Rob L. Pope <rob.pope@inl.gov>; \\ 1 attachments (599 KB) \\ TAN ust-notification-form.pdf;
}

Michael

Attached is the signed Notification for Underground Storage Tank Systems form for the temporary closure of the underground storage tank (UST) at the Idaho National Laboratory (INL), Test Area North (TAN). The tank is identified on the Idaho Underground Storage Tank Management Plan as tank number 98TAN00650, DEQ facility Identification number 6-120618.

The remaining diesel fuel from the UST was pumped into an available above ground compartment storage tank near the existing UST.

The tank meets the Code of Federal Regulation (CFR) - 40 CFR 280.70 - Temporary closure. The fuel in the tank has been removed using commonly employed practices so that no more than 2.5 centimeters (one inch) of residue remain in the tank. The vent line to the tank remains open and functioning, and the lines, pumps, manways, and ancillary equipment have been secured and capped. The UST's meets the performance standards in $\S 280.20$ for new UST systems.

Meeting the temporary closure requirements above, release detection for this tank is no longer required.

If you have any questions or concerns, please contact me.

Kerry L. Nisson

Nuclear Operations Environmental Support - UST TPOC

Office (208) 533-7102

Cell (208) 569-4721

email: kerry.nisson@inl.gov

Materials and Fuels Complex - Mail Stop 6134

https://outlook.office365.com/owa/?realm=inl.gov\&path=/mail/inbox/rp

$10 / 4 / 2018$ 
NOTIFICATION FOR UNDERGROUND STORAgE TANK SYSTEMS

Idaho Department of Environmental Quality, 1410 N Hilton, Boise ID 83706

TYPE OF NOTIFICATION
New Facility Change of Owner
Facility ID

$6-120618$

\section{INSTRUCTIONS - See additional instructions on page 6}

Please type or use ink. This form must be completed for each location containing underground storage tanks. If more than five (5) tanks are owned at this location, photocopy the following sheets, and attach continuation sheets to the form (pages 3,4 , \& 5)

\section{GENERAL INFORMATION}

Notification is required by law for all underground storage tanks (USTs)

storing regulated substances that are brought into use after May 8,1986 , or

USTs in the ground as of May 8, 1986, that have stored regulated substances at any time since January 1,1974 . The information requested is required by Section 9002 of the Resource Conservation and Recovery Act (RCRA), as amended.

The primary purpose of this notification form is to provide information about the installation, existence, changes to, and closure of USTs that store or have stored petroleum or hazardous substances. The information you provide will be based on reasonably available records, or in the absence of such records, your knowledge or recollection.

Who must notify? Unless exempted, owners of USTs that store or will store regulated substances must notify DEQ.

1. Owner means

a) in the case of an UST in use on November 8,1984 , or brought into use after that date, any person who owns an underground storage tank used for the storage, use, or dispensing of regulated substances

b) in the case of an UST in use before November 8,1984 , but no longer in use on that date, any person who owned such tank immediately before the discontinuation of its use

c) in the case of a new installation on or after April 2, 2008, any person who will install an underground storage tank system

d) in the case of an underground storage tank closure, any person who will remove or close in place such tank

e) in the case of changes or updates, any person who will make a change to an UST system

What tanks are included? Underground storage tank is defined as any one or combination of tanks that is used to contain an accumulation of "regulated substances," and whose volume (including connected underground piping) is $10 \%$ or more beneath the ground.

\section{What tanks are excluded?}

1.Tanks with a capacity of 110 gallons or less

2. Farm or residential tanks of 1,100 gallons or less capacity used for storing motor fuel for noncommercial purposes

3. Tanks used for storing heating oil for consumptive use on the premises where stored

4. Septic tanks

5. Certain pipeline facilities regulated under chapters 601 and 603 of Title 49

6. Surface impoundments, pits, ponds, or lagoons

7. Stormwater or wastewater collection systems

8. Flow-through process tanks

$$
\text { 1. OWNERSHIP OF USTS }
$$

Name U.S. Department of Energy, Idaho Operations Office (DOE-ID)

Mailing Address 1955 Fremont Avenue

City Idaho Falls

State Idaho

ZIP Code 83401

County Bonneville

Phone Number (With Area Code) (208) 526-2493

Email sturmir@id.doe.gov
. Liquid traps or associated gathering lines directly related to oil or

gas production and gathering operations

10. Tanks on or above the floor of underground areas, such as basements or tunnels

11. Wastewater treatment tanks

12. UST systems containing radioactive material that are regulated under the Atomic Energy Act of 1954

13. UST systems that are part of an emergency generator system at nuclear power generation facilities regulated by the Nuclear

Regulatory Commission under $10 \mathrm{CFR}$ Part 50

What substances are covered? The notification requirements apply to USTs containing petroleum or certain hazardous substances. Petroleum includes gasoline, used oil, diesel fuel, crude oil, or any fraction thereof which is liquid at standard conditions of temperature and pressure (60 degrees Fahrenheit and 14.7 pounds per square inch absolute). Hazardous substances are those found in section 101 (14) of the Comprehensive Environmental Response, Compensation and Liability Act of 1980 , with the exception of those substances regulated as hazardous waste under Subtitle $\mathrm{C}$ of the Resource Conservation and Recovery Act.

Where to notify? Send completed forms to:

UST Coordinator

Idaho Department of Environmental Quality 1410 N. Hilton

Boise, ID 83706 Telephone: (208) 373-0502

When to notify? Owners of underground storage tank systems that are still in the ground must notify immediately. Owners who bring USTs into use atter May 8, 1986, must notify within 30 days of bringing the tanks into use. Owners who will install an UST system must notify 30 days prior to the installation. Owners who will repiace $50 \%$ of piping connected to a single underground storage tank must notify 24 hours prior to the replacement. Owners who will close an UST must notify 30 days prior to the closure. Owners who have closed an UST must notify and indicate the date of closure. New owners must notify within 30 days of ownership.

Penalties: Any owner who knowingly fails to notify or submits false information shall be subject to a civil penalty.

\section{LOCATION OF USTS}

(If same as Section I, mark box here $\square$ ) Name U.S. Department of Energy. Idaho Operations Office (DOE-ID) Street Address (no PO Box) Central Facilities Area

City Scoville

State Idaho

ZIP Code 83415

County Butte 


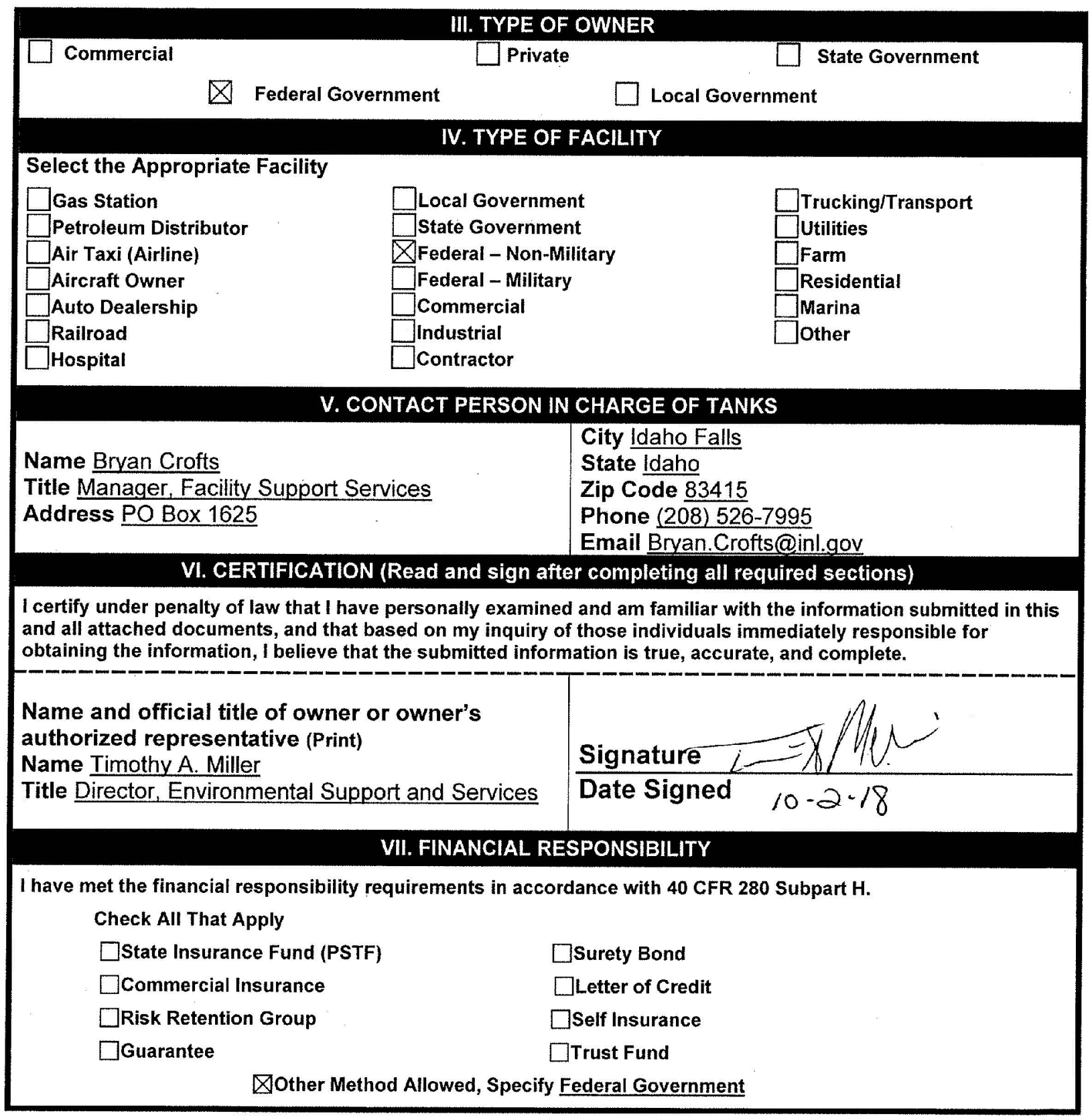




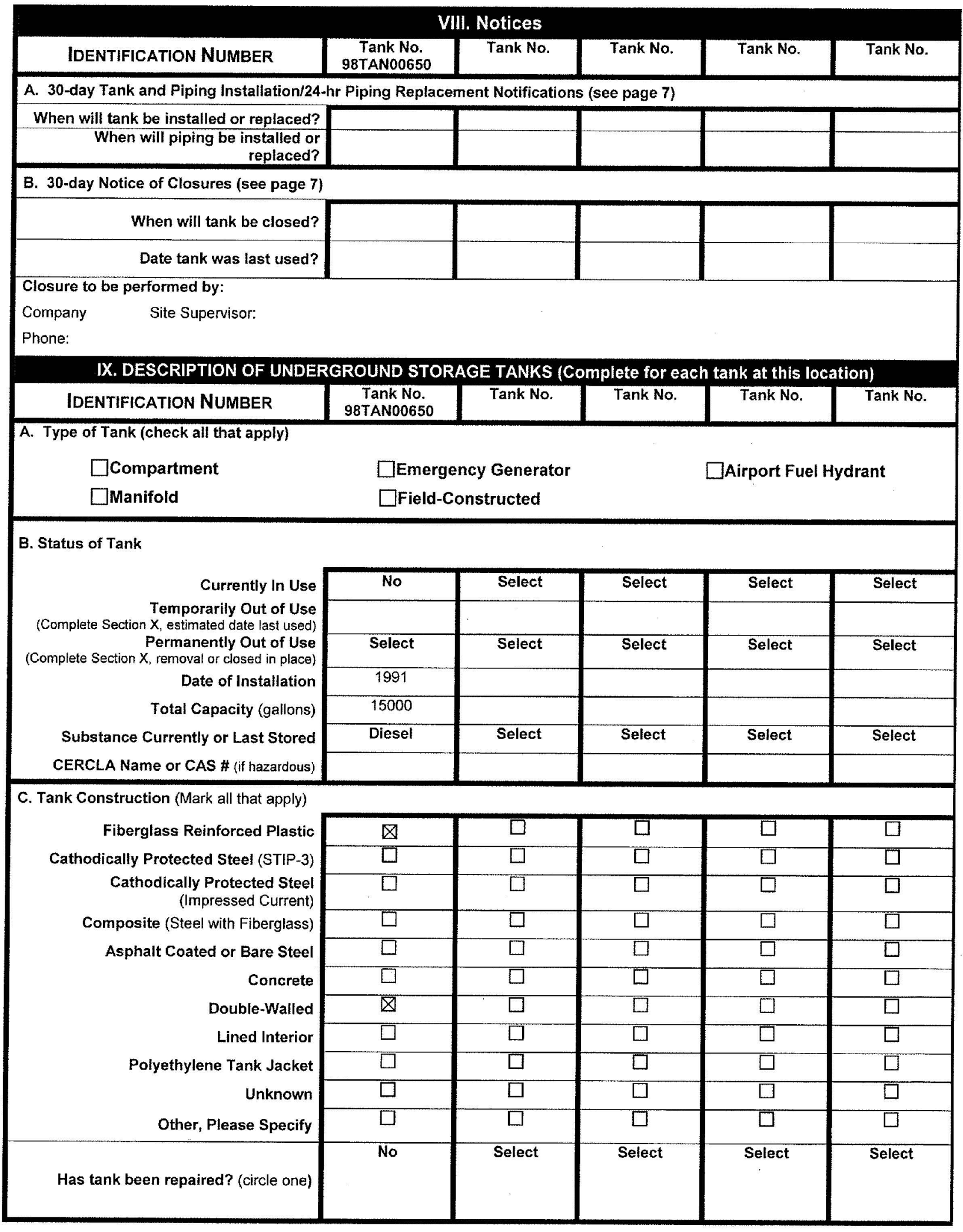

Page 3 
D. Spill and Overfill Protection

\begin{tabular}{|c|c|c|c|c|c|c|c|c|c|c|}
\hline $\begin{array}{r}\text { Overfill Device Installed? } \\
\text { (Alarm, Flapper) }\end{array}$ & \multicolumn{2}{|c|}{ Alarm } & \multicolumn{2}{|c|}{ Select } & \multicolumn{2}{|c|}{ Select } & \multicolumn{2}{|c|}{ Select } & \multicolumn{2}{|c|}{ Select } \\
\hline $\begin{array}{l}\text { Spill Bucket Installed? } \\
\text { (Single Wall or Double Wall) }\end{array}$ & \multicolumn{2}{|c|}{ Single-Walled } & \multicolumn{2}{|c|}{ Select } & \multicolumn{2}{|c|}{ Select } & \multicolumn{2}{|c|}{ Select } & \multicolumn{2}{|c|}{ Select } \\
\hline \multicolumn{11}{|l|}{ E. Piping Construction (Mark all that apply) } \\
\hline Plastic/Flexible & \multicolumn{2}{|c|}{$\square$} & \multicolumn{2}{|c|}{$\square$} & \multicolumn{2}{|c|}{$\square$} & \multicolumn{2}{|c|}{$\square$} & \multicolumn{2}{|c|}{$\square$} \\
\hline Fiberglass Reinforced Plastic & \multicolumn{2}{|c|}{$\bigotimes$} & \multicolumn{2}{|c|}{$\square$} & \multicolumn{2}{|c|}{$\square$} & \multicolumn{2}{|c|}{$\square$} & \multicolumn{2}{|c|}{$\square$} \\
\hline Bare Steel & \multicolumn{2}{|c|}{$\square$} & \multicolumn{2}{|c|}{ [ } & \multicolumn{2}{|c|}{$\square$} & \multicolumn{2}{|c|}{$\square$} & \multicolumn{2}{|c|}{$\square$} \\
\hline $\begin{array}{r}\text { Catholically Protected Steel } \\
\text { (Impressed Current) }\end{array}$ & \multicolumn{2}{|c|}{$\square$} & \multicolumn{2}{|c|}{$\square$} & & & & & & ] \\
\hline Cathodically Protected Steel (Galvanic) & & & & & & & & & & ] \\
\hline Corrosion Protection (Soil Isolation) & & & & & & & & & & ] \\
\hline Double-Walled & & & & & & & & & & ] \\
\hline Unknown & & & & & & & & & & ] \\
\hline Other, Please Specify & & & & & & & & & & ] \\
\hline F. Piping Type (Mark all that Apply) & & & & & & & & & & \\
\hline Pressure & & & & & & & & & & \\
\hline Safe Suction (check valve at dispenser) & & & & & & & & & & \\
\hline U.S. Suction (check valve at tank) & & & & & & & & & & \\
\hline Gravity Feed & & & & & & & & & & \\
\hline Has piping been repaired or replaced? & & & & & & & & & & ect \\
\hline Date of the repair or replacement & & 012 & & & & & & & & \\
\hline G. Release Detection (Mark all that Apply) & Tank & Piping & Tank & Piping & Tank & Piping & Tank & Piping & Tank & Piping \\
\hline Automatic Tank Gauging & $\bigotimes$ & & $\square$ & & $\square$ & & $\square$ & & $\square$ & \\
\hline $\begin{array}{r}\text { Continuous Interstitial Double-Wall } \\
\text { Monitoring (sensors) }\end{array}$ & $凶$ & $\square$ & $\square$ & $\square$ & $\square$ & $\square$ & $\square$ & $\square$ & $\square$ & $\square$ \\
\hline Manual Interstitial Double-Wall & $\square$ & $\square$ & $\square$ & $\square$ & $\square$ & $\square$ & $\square$ & $\square$ & $\square$ & $\square$ \\
\hline & $\square$ & $\square$ & $\square$ & $\square$ & $\square$ & $\square$ & $\square$ & $\square$ & $\square$ & $\square$ \\
\hline Manual Tank Gauging ( 1,000 gallons or less) & $\square$ & & $\square$ & & $\square$ & & $\square$ & & $\square$ & \\
\hline Vapor Monitoring & $\square$ & $\square$ & $\square$ & $\square$ & $\square$ & $\square$ & $\square$ & $\square$ & $\square$ & $\square$ \\
\hline Mechanical Line Leak Detector & & $\square$ & & $\square$ & & $\square$ & & $\square$ & & $\square$ \\
\hline Electronic Line Leak Detector & & $\square$ & & $\square$ & & $\square$ & & $\square$ & & $\square$ \\
\hline Annual Line Tightness Test & & $\square$ & & $\square$ & & $\square$ & & $\square$ & & $\square$ \\
\hline $\begin{array}{r}\text { 3-Year Line Tightness Test } \\
\text { (US Suction Only) }\end{array}$ & & & & & & & & & & \\
\hline $\begin{array}{r}\text { Not Required } \\
\text { (safe suction piping, empty tank) }\end{array}$ & $\triangle$ & $\square$ & $\square$ & $\square$ & $\square$ & $\square$ & $\square$ & $\square$ & $\square$ & $\square$ \\
\hline
\end{tabular}

Page 4 
G. Under-Dispenser Spill Containment (required for new installations, piping replacement and dispenser replacement*)

Is there under-dispenser spill

containment for each new dispenser

Select

island?

$X$. TANKS OUT OF USE OR CHANGE IN SERVICE

\begin{tabular}{|c|c|c|c|c|c|}
\hline TANK IDENTIFICATION NUMBER & $\begin{array}{l}\text { Tank No. } \\
\text { 98TAN00650 }\end{array}$ & Tank No & Tank No & Tank No. & Tank No. \\
\hline \multicolumn{6}{|l|}{ Closing of Tank } \\
\hline \multicolumn{6}{|l|}{ Tank Was Removed From Ground } \\
\hline \multicolumn{6}{|l|}{ Tank Was Closed In Ground } \\
\hline Estimated Date Last Used & $\begin{array}{c}\text { September } 28 \text {, } \\
2018\end{array}$ & & & & \\
\hline \multicolumn{6}{|l|}{ Date Tank Closed } \\
\hline \multicolumn{6}{|l|}{$\begin{array}{l}\text { Tank Filled With Inert Material } \\
\text { (indicate material - sand, concrete) }\end{array}$} \\
\hline \multicolumn{6}{|l|}{$\begin{array}{r}\text { Change in Service } \\
\text { (No longer holds a regulated substance) }\end{array}$} \\
\hline $\begin{array}{r}\text { Site Assessment Completed } \\
\text { (samples taken) }\end{array}$ & Select & Select & Select & Select & Select \\
\hline Evidence of a Release Detected? & Select & Select & Select & Select & Select \\
\hline Release Reported to DEQ? & Select & Select & Select & Select & Select \\
\hline Date Release Reported to DEQ & & & & & \\
\hline
\end{tabular}

\section{CERTIFICATION OF COMPLIANCE}

(Complete for installation of all new tanks and/or piping or for upgrading existing tanks and/or piping)

\begin{tabular}{|l|l|l|l|l|}
\hline TANK IDENTIFICATION NUMBER & Tank No. & Tank No. & Tank No. Nank No. \\
\hline
\end{tabular}

A. Installation (Mark all that apply)

Installer certified by tank and piping manufacturers

Installer certified or licensed by a State

Installation is inspected by a registered engineer

Installation inspected by $D E Q$

Manufacturer's installation checklists have been completed

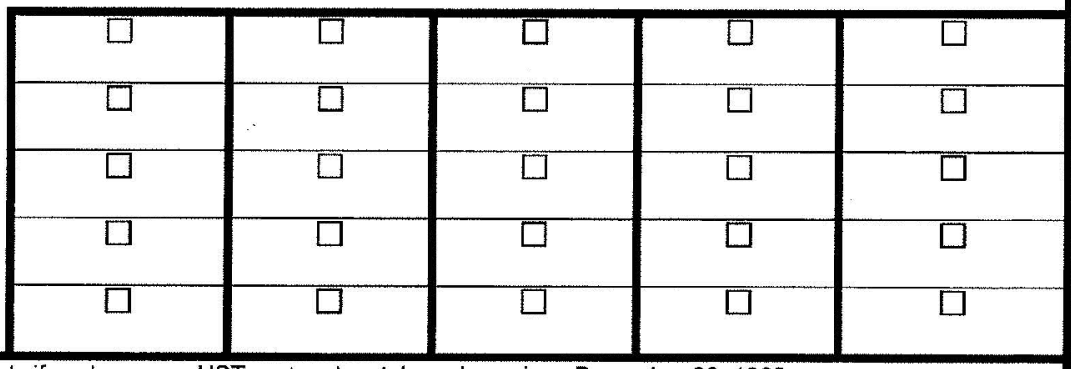

Note: The installer must complete this section only if work on your UST system has taken place since December 22, 1988.

OATH: 1 certify the information concerning installation is true to the best of my belief and knowledge.

Installation Company

Address:

Installer Name

Phone

Signature

Date

*When a dispenser is replaced and any equipment necessary to connect the dispenser to the underground storage tank system under the dispenser is installed; under dispenser containment is required. 
Appendix B, CCN: 247669 - Permanent Closure - 30 Day Notification for Underground Storage Tank Systems - Test Area North (DEQ Facility ID\# 6-120618)

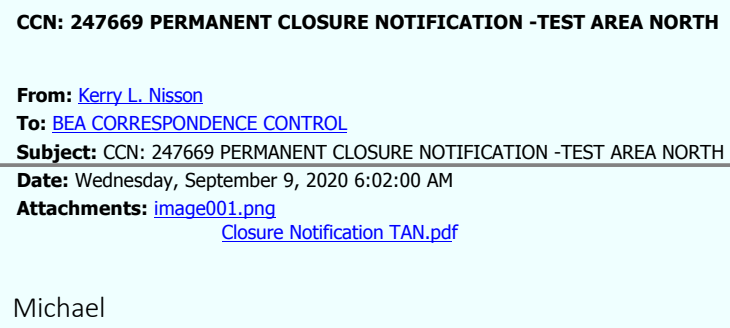

Kerry Nisson

Idaho National Laboratory | P.O. Box 1625 | Idaho Falls, ID

83415

Environment Support and Services/ UST TPOC

Phone: 208-533-7102 | Cell: 208-569-4721

Kerry.Nisson@INL.gov 


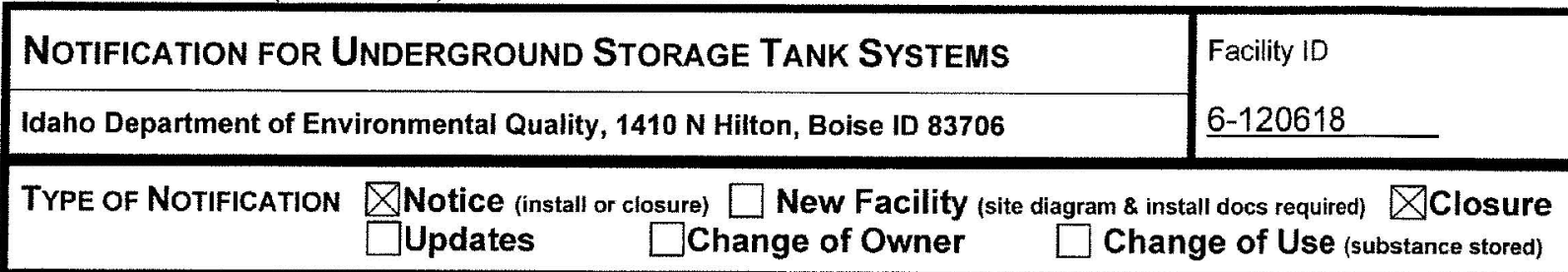

\section{INSTRUCTIONS - See additional instructions on page 6}

Please type or use ink. This form must be completed for each location containing underground storage tanks. If more than five (5) tanks are owned at this location, photocopy the following sheets, and attach continuation sheets to the form (pages 3,4 , \& 5)

\section{GENERAL INFORMATION}

Notification is required by law for all underground storage tanks (USTs) storing regulated substances that are brought into use after May 8,1986 , or USTs in the ground as of May 8, 1986, that have stored regulated substances at any time since January 1,1974 . The information requested is required by Section 9002 of the Resource Conservation and Recovery Act (RCRA), as amended.

The primary purpose of this notification form is to provide information about the installation, existence, changes to, and closure of USTs that store or have stored petroleum or hazardous substances. The information you provide will be based on reasonably available records, or in the absence of such records, your knowledge or recollection.

Who must notify? Unless exempted, owners of USTs that store or will store regulated substances must notify $D E O$.

1. Owner means

a) in the case of an UST in use on November 8,1984 , or brought into use after that date, any person who owns an underground storage tank used for the storage, use, or dispensing of regulated substances

b) in the case of an UST in use before November 8.1984, but no longer in use on that date, any person who owned such tank immediately before the discontinuation of its use

c) in the case of a new installation on or after April 2, 2008, any person who will install an underground storage tank system

d) in the case of an underground storage tank closure, any person who will remove or close in place such tank

e) in the case of changes or updates, any person who will make a change to an UST system

What tanks are included? Underground storage tank is defined as any one or combination of tanks that is used to contain an accumulation of "regulated substances," and whose volume (including connected underground piping) is $10 \%$ or more beneath the ground.

\section{What tanks are excluded?}

1.Tanks with a capacity of 110 gallons or less

2. Farm or residential tanks of 1,100 gallons or less capacity used for storing

motor fuel for noncommercial purposes

3. Tanks used for storing heating oil for consumptive use on the premises

where stored

4. Septic tanks

5. Certain pipeline facilities regulated under chapters 601 and 603 of Title 49

6. Surface impoundments, pits, ponds, or lagoons

7. Stormwater or wastewater collection systems

8. Flow-through process tanks

9. Liquid traps or associated gathering lines directly related to oll ar

gas production and gathering operations

10. Tanks on or above the floor of underground areas, such as basements or tunnels

11. Wastewater treatment tanks

12. UST systems containing radioactive material that are regulated under the Atomic Energy Act of 1954

13. UST systems that are part of an emergency generator system at nuclear power generation facilities regulated by the Nuclear

Regulatory Commission under 10 CFR Part 50

What substances are covered? The notification requirements apply to USTs containing petroleum or certain hazardous substances. Petroleum includes gasoline, used oil, diesel fuel, crude oil, or any fraction there of which is liquid at standard conditions of temperalure and pressure $(60$ degrees Fahrenheit and 14.7 pounds per square inch absolute). Hazardous substances are those found in section 101 (14) of the Comprehensive Environmental Response, Compensation and Liability Act of 1980, with the exception of those substances regulated as hazardous waste under Subtitle $C$ of the Resource Conservation and Recovery Act.

Where to notify? Send completed forms to:

UST Coordinator

Idaho Department of Environmental Quality $1410 \mathrm{~N}$. Hilton

Boise, ID 83706 Telephone: (208) 373-0502

When to notify? Owners of underground storage tank systems that are still in the ground must notify immediately. Owners who bring USTs into use after May 8, 1986, must notify within 30 days of bringing the tanks into use. Owners who will install an UST system must notify 30 days prior to the installation. Owners who will replace $100 \%$ of piping connected to a single underground storage tank must notify 24 hours prior to the replacement. Owners who will close an UST must notify 30 days prior to the closure. Owners who have closed an UST must notify and indicate the date of closure. New owners must notify within 30 days of ownership.

Penalties: Any owner who knowingly fails to notify or submits false information shall be subject to a civil penalty.

\section{OWNERSHIP OF USTS}

\section{LOCATION OF USTS}

Name U.S. Department of Energy, Idaho Operations Office (DOE-ID)

Mailing Address 1955 Fremont Avenue

City Idaho Falls

State Idaho

ZIP Code 83401

County 83401

Phone Number (With Area Code) (208) 526-4612

Email ljungbe@id.idaho.gov

(If same as Section I, mark box here $\square$ ) Business Name U.S. Department of Energy, Idaho Operations Office (DOE-ID) Street Address (no PO Box) Teat Area North City Scoville

State Idaho ZIP Code 83415 County Butte 


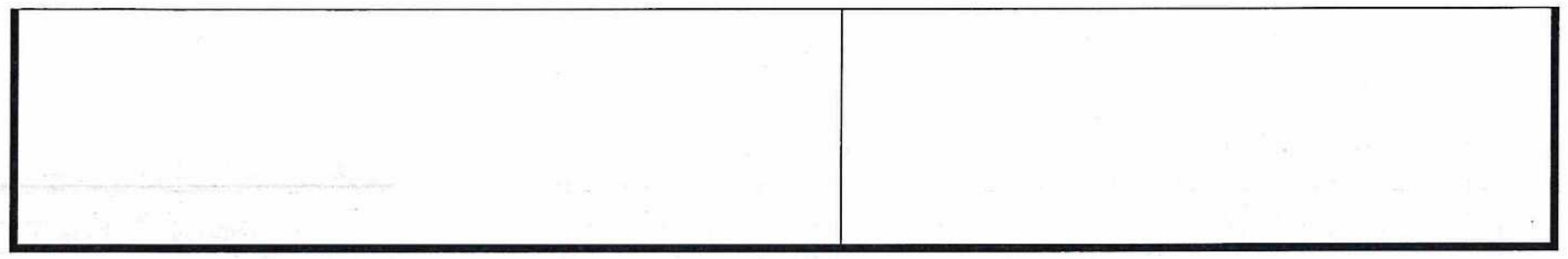

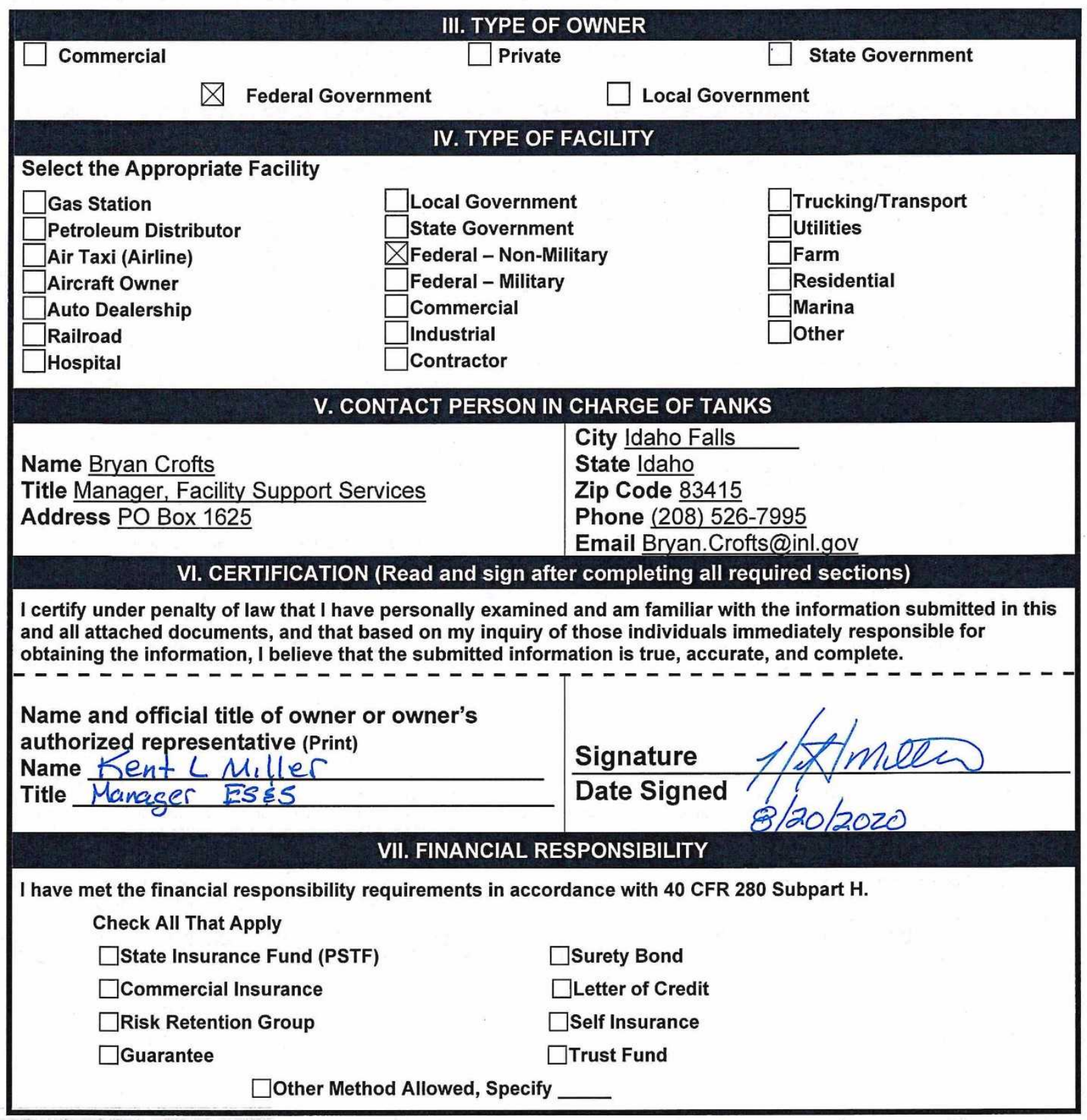


VIII. Notices \begin{tabular}{l|c|c} 
IDENTIFICATION NUMBER & $\begin{array}{c}\text { Tank No. } \\
\text { 98TAN00650 }\end{array}$ & Tank No. \\
\hline
\end{tabular}

Tank No.

Tank No.

Tank No.

A. 30-day Tank and Piping Installation/24-hr Piping Replacement Notifications (see page 7)

Date tank will be installed or replaced?

Date piping will be installed or

replaced?

B. 30-day Natice of Closures (see page 7)

\begin{tabular}{|c|c}
\hline Date tank will be closed? & $\begin{array}{c}\text { Temp closed } \\
10 / 2 / 18\end{array}$ \\
\hline Date tank was last used? & $9 / 2018$
\end{tabular}

Closure to be performed by:

Company Idaho National Laboratory Site Supervisor: Steven Christensen

Phone: $(208) 526-4743$

IX. DESCRIPTION OF UNDERGROUND STORAGE TANKS (Complete for each tank at this location)

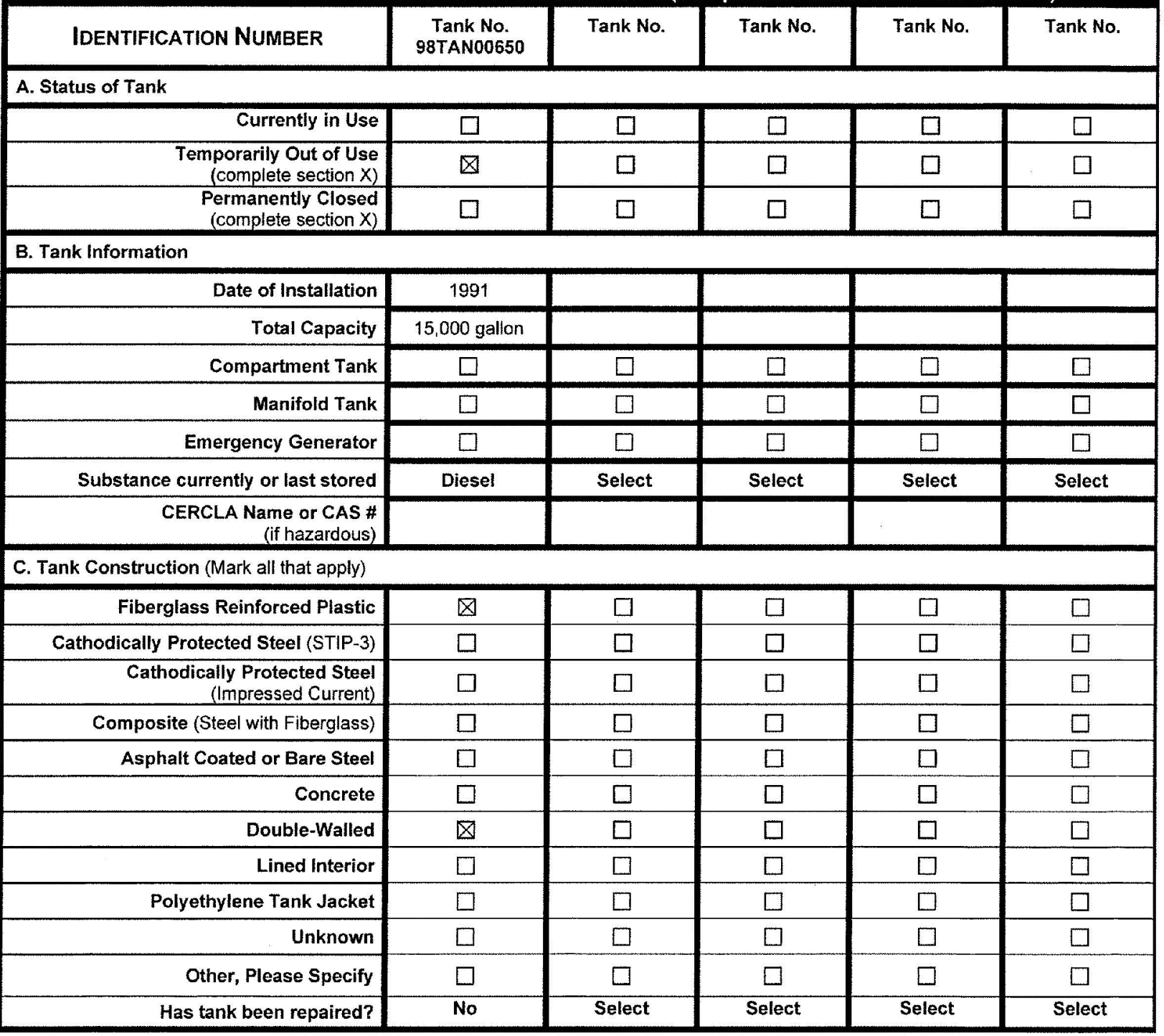

Page 3 
D. Spill and Overfill Protection

\begin{tabular}{|r|c|c|c|c|c|}
\hline $\begin{array}{r}\text { Overfill Device Installed? } \\
\text { (Alarm, Flapper, Ball Float) }\end{array}$ & Alarm & Select & Select & Select & Select \\
\hline $\begin{array}{r}\text { Spill Bucket Installed? } \\
\text { (Single Wall or Double Wall) }\end{array}$ & Single-Walled & Select & Select & Select & Select \\
\hline
\end{tabular}

E. Piping Construction (Mark all that apply)

\begin{tabular}{|c|c|c|c|c|c|}
\hline $\begin{array}{r}\text { Plastic/Flexible } \\
\end{array}$ & $\square$ & $\square$ & $\square$ & $\square$ & $\square$ \\
\hline Fiberglass Reinforced Plastic & 冈 & $\square$ & $\square$ & $\square$ & $\square$ \\
\hline Bare Steel & $\square$ & $\square$ & $\square$ & $\square$ & $\square$ \\
\hline $\begin{array}{r}\text { Cathodically Protected Steel } \\
\text { (Impressed Current) }\end{array}$ & $\square$ & $\square$ & $\square$ & $\square$ & $\square$ \\
\hline $\begin{array}{r}\text { Cathodically Protected Steel } \\
\text { (Galvanic) }\end{array}$ & $\square$ & $\square$ & $\square$ & $\square$ & $\square$ \\
\hline Corrosion Protection (Soil Isolation) & $\square$ & $\square$ & $\square$ & $\square$ & $\square$ \\
\hline Double-Walled & $\square$ & $\square$ & $\square$ & $\square$ & $\square$ \\
\hline Unknown & $\square$ & $\square$ & $\square$ & $\square$ & $\square$ \\
\hline Other, Please Specify & $\square$ & $\square$ & $\square$ & $\square$ & $\square$ \\
\hline
\end{tabular}

F. Piping Type (Mark all that Apply)

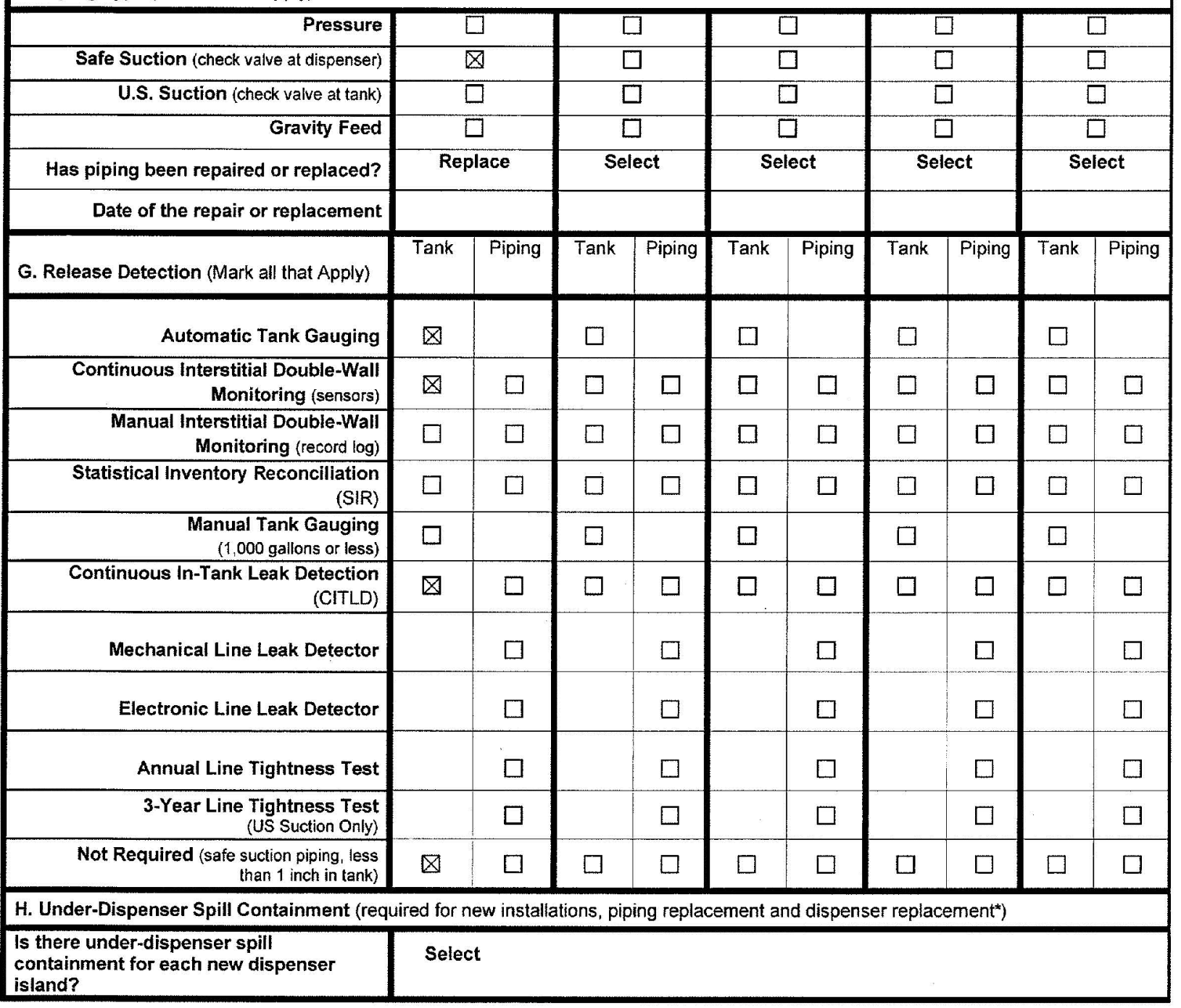

Page 4 


\begin{tabular}{|c|c|c|c|c|c|}
\hline TANK IDENTIFICATION NUMBER & Tank No. & Tank No. & Tank No. & Tank No. & Tank No. \\
\hline \multicolumn{6}{|l|}{ Closing of Tank } \\
\hline \multicolumn{6}{|l|}{ Estimated Date Last Used } \\
\hline $\begin{array}{r}\text { Date Tank Was Removed From } \\
\text { Ground }\end{array}$ & $\square$ & $\square$ & $\square$ & $\square$ & $\square$ \\
\hline Date Tank Was Closed In Ground & $\square$ & $\square$ & $\square$ & $\square$ & $\square$ \\
\hline \multicolumn{6}{|l|}{$\begin{array}{l}\text { Tank Filled With Inert Material } \\
\text { (indicate material - sand, concrete) }\end{array}$} \\
\hline $\begin{array}{r}\text { Change in Service } \\
\text { (No longer holds a regulated substance) } \\
\end{array}$ & $\square$ & $\square$ & $\square$ & $\square$ & $\square$ \\
\hline $\begin{array}{r}\text { Site Assessment Completed } \\
\text { (samples taken) }\end{array}$ & Select & Select & Select & Select & Select \\
\hline Evidence of a Release Detected? & Select & Select & Select & Select & Select \\
\hline Release Reported to DEQ? & Select & Select & Select & Select & Select \\
\hline Date Release Reported to DEQ & & & & & \\
\hline
\end{tabular}

\begin{tabular}{|c|c|c|c|c|c|}
\hline \multicolumn{6}{|c|}{$\begin{array}{l}\text { XI. CERTIFICATION OF COMPLIANCE } \\
\text { (Complete for installation of all new tanks and/or piping or for upgrading existing tanks and/or piping) }\end{array}$} \\
\hline TANK IDENTIFICATION NUMBER & Tank No. & Tank No. & Tank No. & Tank No. & Tank No. \\
\hline \multicolumn{6}{|l|}{ A. Installation (Mark all that apply) } \\
\hline $\begin{array}{r}\text { Installer certified by tank and piping } \\
\text { manufacturers }\end{array}$ & $\square$ & $\square$ & $\square$ & $\square$ & $\square$ \\
\hline $\begin{array}{r}\text { Installer certified or licensed by a } \\
\text { State }\end{array}$ & $\square$ & $\square$ & $\square$ & $\square$ & $\square$ \\
\hline $\begin{array}{r}\text { Installation is inspected by a } \\
\text { registered engineer } \\
\end{array}$ & $\square$ & $\square$ & $\square$ & $\square$ & $\square$ \\
\hline Installation inspected by DEQ & $\square$ & $\square$ & $\square$ & $\square$ & $\square$ \\
\hline $\begin{array}{r}\text { Manufacturer's installation checklists } \\
\text { have been completed }\end{array}$ & $\square$ & $\square$ & $\square$ & $\square$ & $\square$ \\
\hline $\begin{array}{l}\text { Note: The installer must complete this section on } \\
\text { OATH: I certify the information concerning } \\
\text { Installation Company } \\
\text { Address: } \\
\text { Installer Name } \\
\text { Phone } \\
\text { Signature } \\
\text { Date }\end{array}$ & $\begin{array}{l}\text { work on your } \\
\text { allation is }\end{array}$ & $\begin{array}{l}\text { ystem has } \\
\text { the best } 0\end{array}$ & $\begin{array}{l}\text { ice since } \mathrm{D} \\
\text { lief and } \mathrm{kr}\end{array}$ & 22, 1988. & \\
\hline
\end{tabular}




\section{Appendix C - UST Removal TOS-302 Sampling Logbook Test Area North (DEQ Facility ID\# 6-}

120618)

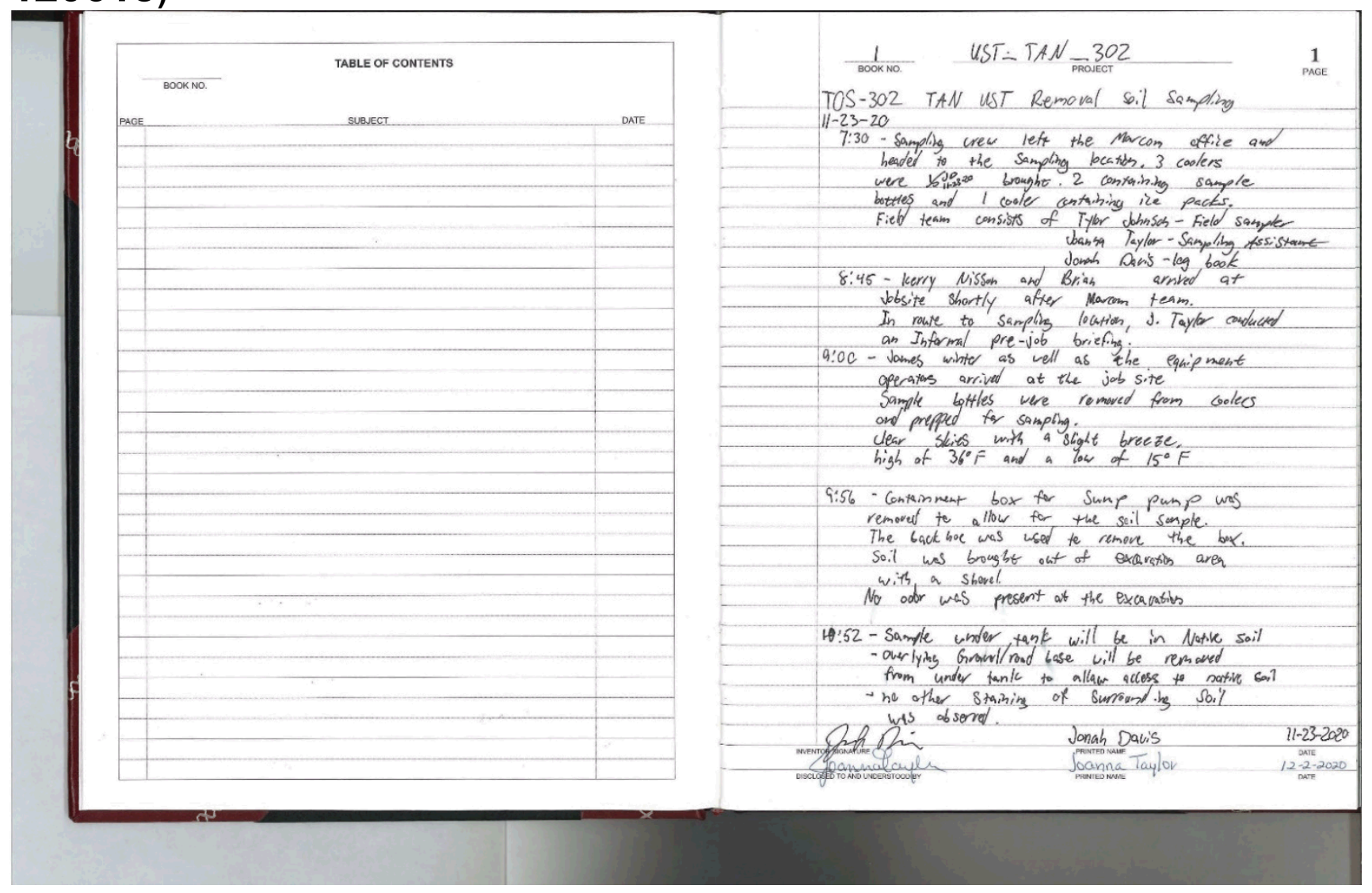




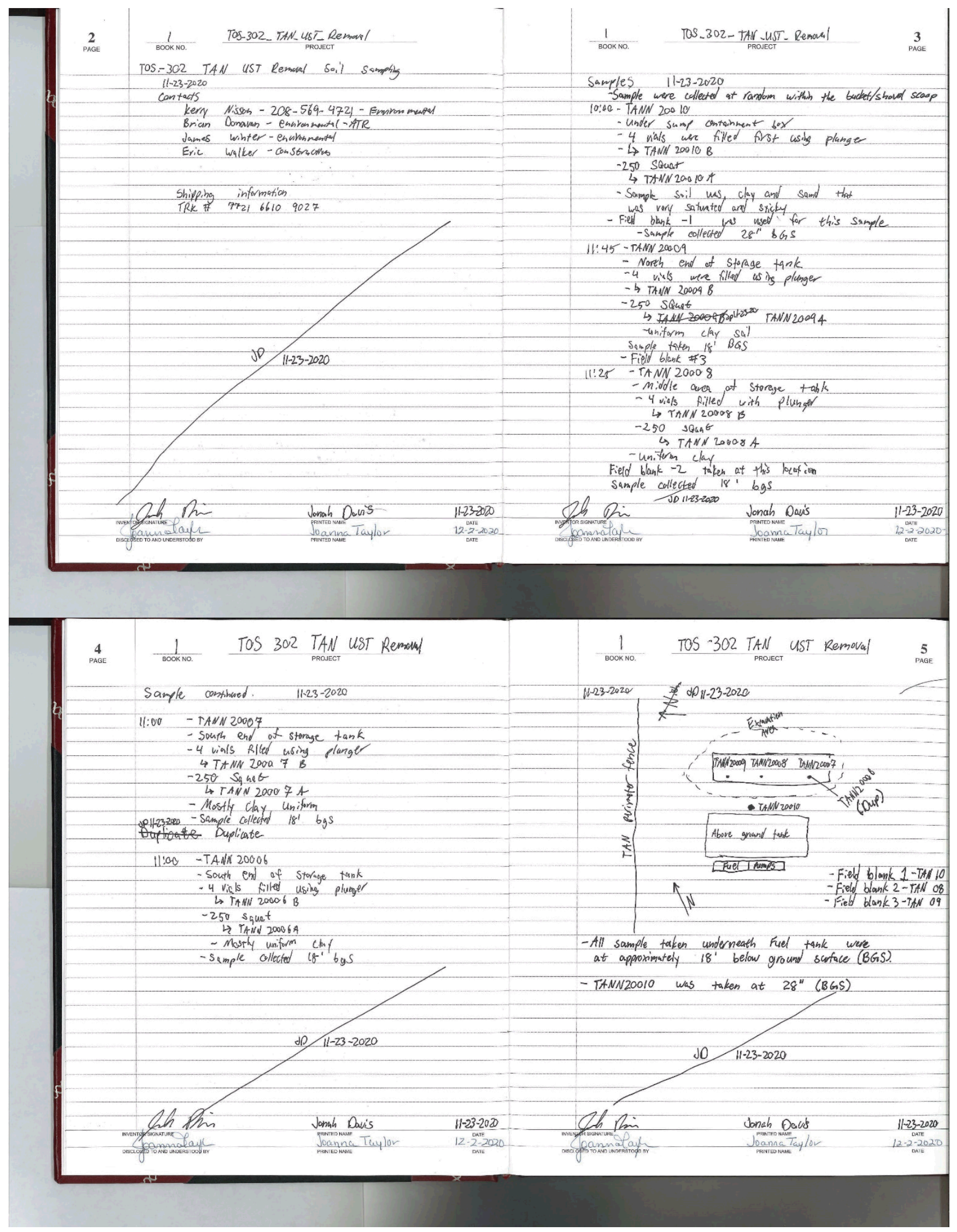


Appendix D - UST Removal TOS-302 Sampling Event Narrative Test Area North (DEQ Facility ID\# 6-

120618 


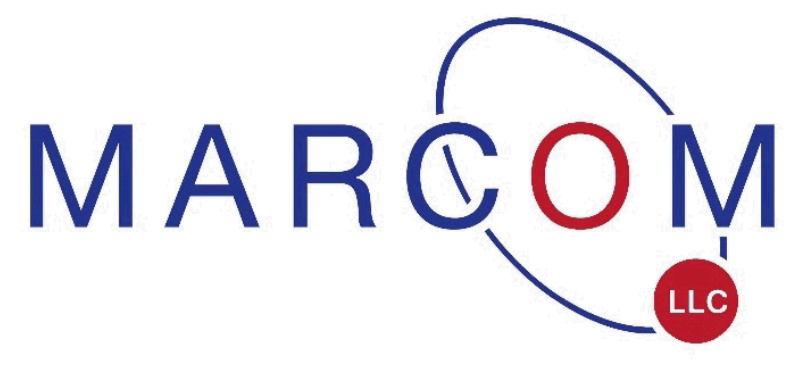

\section{Sampling Event Narrative}

\begin{tabular}{|l|l|}
\hline Date: & $11 / 23 / 2020$ \\
\hline Organization: & BEA \\
\hline TPOC: & Kerry Nisson \\
\hline Project Name: & $\begin{array}{l}302 \_ \text {Removal of Underground } \\
\text { Fuel Storage Tank TAN }\end{array}$ \\
\hline Sampling Event\#: & TOS-302 \\
\hline TOS\#: & 302 \\
\hline Laboratory: & GEL \\
\hline WO/SDG: & 528429 \\
\hline
\end{tabular}




\section{MARCOM}

\begin{tabular}{l|ll|}
$\begin{array}{l}\text { 302_REMOVAL OF UNDERGROUND FUEL STORAGE } \\
\text { TANKS_TAN }\end{array}$ & $\begin{array}{l}\text { Sample Event: } \\
\text { Page: }\end{array}$ & $\begin{array}{l}\text { SE-302 } \\
1 \text { of } 10\end{array}$ \\
\hline
\end{tabular}

\section{Table of Contents}

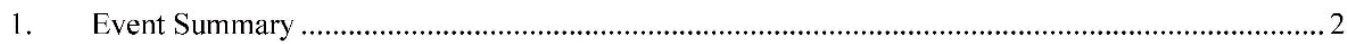

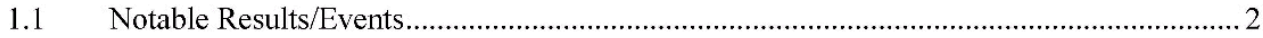

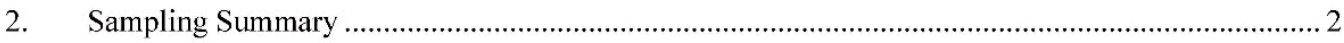

2.1 Ship Screens .............................................................................................. 2

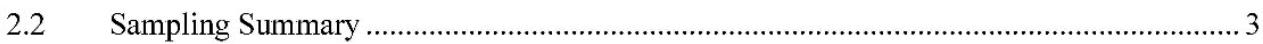

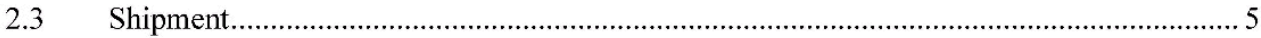

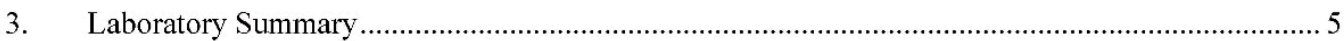

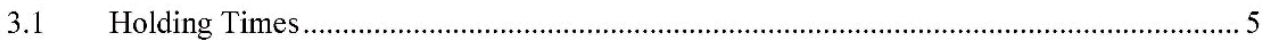

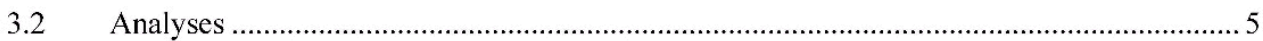

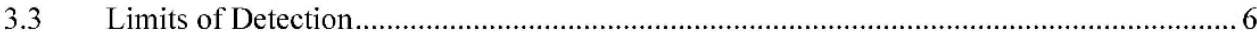

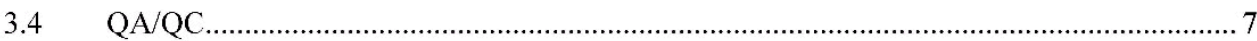

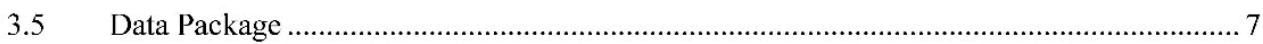

3.6 Sample Analysis Identification...................................................................................... 7

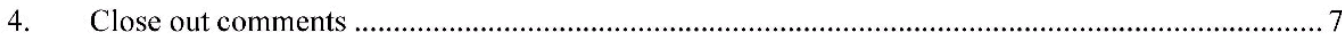

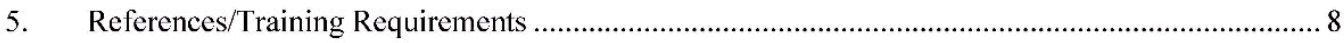

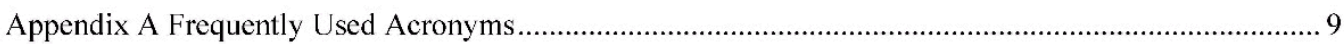




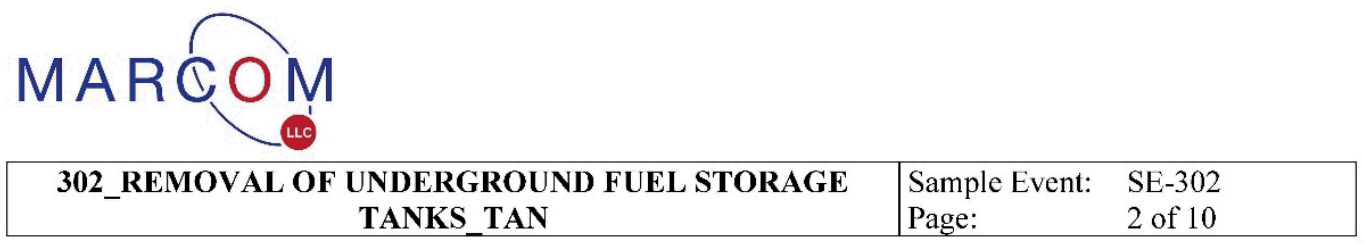

\section{EVENT SUMMARY}

The sampling activity will support Battelle Energy Alliance (BEA) in a permanent closure of the underground storage tank (UST) at Test Area North (TAN). Per conversation from BEA, Idaho Department of Environmental Quality (IDEQ) requires three samples to be taken under the UST (one at each end of the tank and one in the middle), another sample will be taken under the transition sump. IDEQ may also require a sample from under the diesel dispenser that was formerly used for the UST, depending on any soil staining. If a sample is required under the dispenser, the INL would have to auger into the soil below the dispenser to sample.

There is a piping transition sump $\sim 23$-feet from the UST adjacent to the concrete pad for the above ground fuel storage tank. A sample would be required under the sump and not to remove soil from underneath the transition sump until a sample could be taken. IDEQ also stated that they would like to see the transition sump at the time of sampling.

IDEQ stated as the concrete is removed from around the spill bucket, any staining of the soil should be noted, and pictures should be taken of the staining. Stained soil should be properly contained and detailed in notes.

IDEQ requested that the laboratory and sampling described in the "Fact Sheet: How DEQ Evaluates Sample Collection and Data Analysis for UST Closures and Release Investigations" is followed. MarCom will need to ensure the laboratory selected for analysis could meet the screening detection criteria required and would provide QA/QC controls.

Data collected from the samples will be compared to the petroleum chemical of interest (COI) in the sample to the screening levels, obtained from Table 2 in the Risk Evaluation Manual for Petroleum Releases-August 2018.

\subsection{Notable Results/Events}

N/A

\section{SAMPLING SUMMARY}

\subsection{Ship Screens}

Shipment screening was not necessary, for this sampling event, because the samples were collected outside of a INL regulated perimeter or radiological area. 


\section{MARCOM}

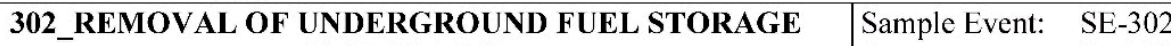

TANKS_TAN

Page: $\quad 3$ of 10

\subsection{Sampling Summary}

On November 23, 2020 Samples were collected from the excavated area near the TAN facility. The excavated area, containing the underground storage tank, is located approximately 100 feet southeast of the TAN perimeter fence (See Figure 1). The Sampling crew was unable to enter the excavated area due to the safety concerns driven by the instability of the excavation. Because of this, the sampling crew was not allowed to enter the excavation area while the digging equipment was active and required to stay at least 6 feet away from the edge of the hole.

Samples were collected at multiple locations from within the bucket/shovel scoop. The samples were collected to exclude rocks and other debris. The 4 vial soil kits were collected by using the provided plunger that was only used for its unique sample. The $250 \mathrm{~mL}$ soil samples were collected using a stainless-steel spoon that was also unique to its respective sample. Throughout the sampling event, crew members noted there was no organic smells associated with the excavation. Also, there was no stained soil observed within the excavated area.

Construction workers removed the sump pump's containment box which revealed the underlying soil. TANN20010 was collected from under the containment box. The sample material was brought to the sampling crew, by construction workers, on a shovel. TANN0009, TANN0008, TANN0007, and TANN0006 (Duplicate) were collected from native soil underneath the storage tank (See Figure 1). Operators removed the overlying gravel from the excavation to reveal the native soil underneath. Once the native soil was exposed, the excavator would collect a bucket full of soil and set the bucket on the ground to allow the sampling crew access to the material. Pertinent information of the sample was noted in the logbook, and the sample bottles were labeled immediately following their collection. Once complete, the samples containers were placed on ice in coolers.

Table 1. Sample Collection Information obtained from the Sampler

\begin{tabular}{|l|l|l|}
$\begin{array}{c}\text { Date/Time } \\
\text { Sample } \\
\text { Collection }\end{array}$ & MarCom ID\# & \multicolumn{1}{c|}{ Description } \\
\hline $\begin{array}{l}11 / 23 / 2020- \\
11: 00\end{array}$ & TANN20006 & $\begin{array}{l}\text { Duplicate sample of TANN20007. Uniform clay soil collected } \\
18 \text { feet Below Ground Surface (BGS). }\end{array}$ \\
\hline $\begin{array}{l}11 / 23 / 2020- \\
11: 00\end{array}$ & TANN20007 & Uniform clay soil collected from 18 feet BGS. \\
\hline $\begin{array}{l}11 / 23 / 2020- \\
11: 25\end{array}$ & TANN20008 & $\begin{array}{l}\text { Uniform clay soil collected from 18 feet BGS. Field blank } 2 \\
\text { was present at this location. }\end{array}$ \\
\hline $\begin{array}{l}11 / 23 / 2020- \\
11: 45\end{array}$ & TANN20009 & $\begin{array}{l}\text { Uniform clay soil collected from 18 feet BGS. Field blank } 3 \\
\text { was present at this location. }\end{array}$ \\
\hline
\end{tabular}

TEM-0800 (10/01//2019 Rev. 0) 


\section{MARCOM}

\begin{tabular}{|c|ll|}
\hline 302_REMOVAL OF UNDERGROUND FUEL STORAGE & Sample Event: & SE-302 \\
TANKS_TAN & Page: & 4 of 10 \\
\hline
\end{tabular}

\begin{tabular}{|l|l|l|}
\hline $\begin{array}{l}\text { 11/23/2020 - } \\
10: 00\end{array}$ & TANN20010 & $\begin{array}{l}\text { Soil was clay with sand that was saturated/sticky and difficult } \\
\text { to sample. Field Blank 1 was present at this location. Sample } \\
\text { was collected from 28 inches BGS. }\end{array}$ \\
\hline $\begin{array}{l}11 / 23 / 2020- \\
10: 00\end{array}$ & Field Blank 1 & $\begin{array}{l}\text { Field blank bottle was opened and kept near sampling site of } \\
\text { TANN20010. }\end{array}$ \\
\hline $\begin{array}{l}11 / 23 / 2020- \\
11: 25\end{array}$ & Field Blank 2 & $\begin{array}{l}\text { Field blank bottle was opened and kept near sampling site of } \\
\text { TANN20008 }\end{array}$ \\
\hline $\begin{array}{l}11 / 23 / 2020- \\
11: 45\end{array}$ & Field Blank 3 & $\begin{array}{l}\text { Field blank bottle was opened and kept near sampling site of } \\
\text { TANN20009 }\end{array}$ \\
\hline $11 / 23 / 2020-$ N/A & Trip Blank & $\begin{array}{l}\text { Trip blank was left in sample coolers throughout entire } \\
\text { sampling event. }\end{array}$ \\
\hline
\end{tabular}

Figure 1. Soil sample locations

Note: Due to safety concerns, GPS points could not be collected. All sample locations are approximate.

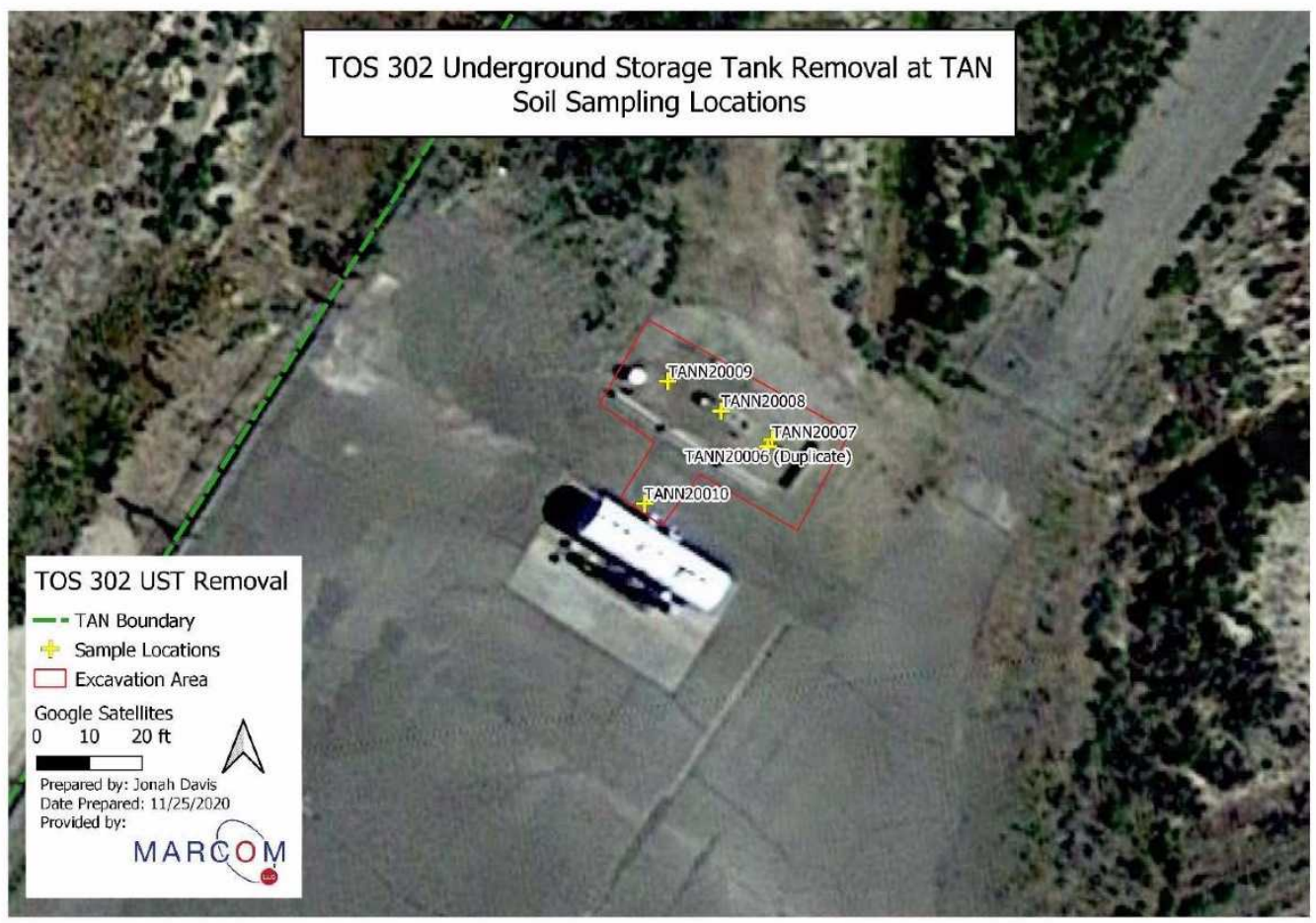

TEM-0800 (10/01//2019 Rev. 0) 


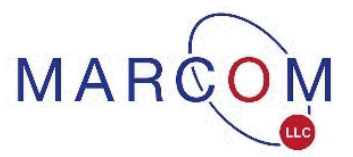

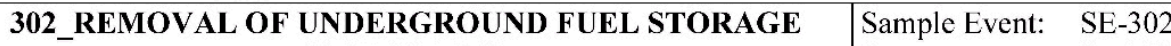

TANKS_TAN $\quad$ Page: $\quad 5$ of 10

\subsection{Shipment}

On November 23,2020, each of the 9 samples were placed into a cooler until completion of packaging at MarCom and subsequent shipment by FedEx Express. All chain of custody documentation was completed with a copy sent in the cooler with the samples. Samples were mailed on November 23, 2020 with sample receipt occurring on November 24, 2020.

\section{LABORATORY SUMMARY}

\subsection{Holding Times}

Samples were received at the laboratory on November 24, 2020 and the data report was received on December 2, 2020. All samples met the holding requirements as see in Table 2 below.

Table 2. Sample specific requirements from GEL laboratory

\begin{tabular}{|c|c|c|c|c|}
\hline Analysis & \multicolumn{1}{|c|}{ Sample Bottle (type/size) } & $\begin{array}{c}\text { Minimum Sample } \\
\text { Amount }\end{array}$ & Preservative & $\begin{array}{c}\text { Maximum Holding } \\
\text { Time }\end{array}$ \\
\hline $\begin{array}{c}\text { BTEX, EDB, EDC, } \\
\text { MTBE }\end{array}$ & O2Si Kit 5035 soil kit (4 vial kit) & NA & $0<6{ }^{\circ} \mathrm{C}$, & $\begin{array}{c}48 \text { hours for } \\
\text { preservation } 14 \text { days for } \\
\text { analysis }\end{array}$ \\
\hline PAH & $\begin{array}{l}250 \mathrm{~mL} \text { Amber glass, Teflon- } \\
\text { lined cap }\end{array}$ & $200 \mathrm{~g}$ & $0<6^{\circ} \mathrm{C}$, & $\begin{array}{c}14 \text { days for extraction. } \\
40 \\
\text { days after extraction }\end{array}$ \\
\hline
\end{tabular}

\subsection{Analyses}

IVOA-A-018 BTEX, EDB, EDC, METBE has no direct line item with GEL so the custom list of VOAA-007 for water and VOA-A-008 for solid. ISVO-A-014 PAHs is SVO-A-008 for liquid and SVO-A-009 for solids. These are shown in Table 3 below.

Table 3. Sample Analysis Identification

\begin{tabular}{|l|l|l|l|l|}
\hline Laboratory ID & MarCom ID & Matrix & Line-Item Code & Method \\
\hline 528429001 & Field Blank & Water & SVO-A-008 & SW-846 8270 SIM \\
\hline 528429002 & TANN20006 & Soil & SVO-A-009 & SW-846 8270 SIM \\
\hline 528429002 & TANN20006 & Soil & VOA-A-003 & SW-846 5035B \\
\hline 528429002 & TANN20006 & Soil & VOA-A-008 & SW-846 8260 \\
\hline 528429003 & TANN20007 & Soil & SVO-A-009 & SW-846 8270 SIM \\
\hline 528429003 & TANN20007 & Soil & VOA-A-003 & SW-846 5035B \\
\hline 528429003 & TANN20007 & Soil & VOA-A-008 & SW-846 8260 \\
\hline 528429004 & TANN20008 & Soil & SVO-A-009 & SW-846 8270 SIM \\
\hline 528429004 & TANN20008 & Soil & VOA-A-003 & SW-846 5035B \\
\hline 528429004 & TANN20008 & Soil & VOA-A-008 & SW-846 8260 \\
\hline
\end{tabular}




\section{MARCOM}

\begin{tabular}{|c|c|}
\hline $\begin{array}{l}\text { 302_REMOVAL OF UNDERGROUND FUEL STORAGE } \\
\text { TANKS_TAN }\end{array}$ & $\begin{array}{ll}\text { Sample Event: } & \text { SE-302 } \\
\text { Page: } & 6 \text { of } 10\end{array}$ \\
\hline
\end{tabular}

\begin{tabular}{|l|l|l|l|l|}
\hline 528429005 & TANN20009 & Soil & SVO-A-009 & SW-846 8270 SIM \\
\hline 528429005 & TANN20009 & Soil & VOA-A-003 & SW-846 5035B \\
\hline 528429005 & TANN20009 & Soil & VOA-A-008 & SW-846 8260 \\
\hline 528429006 & TANN20010 & Soil & SVO-A-009 & SW-846 8270 SIM \\
\hline 528429006 & TANN20010 & Soil & VOA-A-003 & SW-846 5035B \\
\hline 528429006 & TANN20010 & Soil & VOA-A-008 & SW-846 8260 \\
\hline 528429008 & Trip Blank & Water & VOA-A-007 & SW-486 8260 \\
\hline
\end{tabular}

\subsection{Limits of Detection}

Limits of detection are as stated in the TOS and in Table 4 below.

Table 4. Screening levels concentrations for Groundwater Protection for Diesel/Fuel Oil No. 2/Kerosene unrestricted use.

\begin{tabular}{|l|c|}
\hline \multicolumn{1}{|c|}{ Chemical } & $\begin{array}{c}\text { Screening Level } \\
{[\mathbf{m g} / \mathbf{k g}]}\end{array}$ \\
\hline Benzene & $\mathbf{0 . 0 2 5}$ \\
\hline Toluene & $\mathbf{6 . 6}$ \\
\hline Ethyl benzene & 7.4 \\
\hline Xylenes (mixed) & 93 \\
\hline Ethylene Dibromide (EDB) & $\mathbf{0 . 0 0 0 1 4}$ \\
\hline 1,2 Dichloroethane (EDC) & $\mathbf{0 . 0 1 3}$ \\
\hline $\begin{array}{l}\text { Methyl Tert-Butyl Ether } \\
\text { (MTBE) }\end{array}$ & $\mathbf{0 . 0 8}$ \\
\hline Acenaphthene & $\mathbf{2 0 0}$ \\
\hline Anthracene & $\mathbf{3 2 0 0}$ \\
\hline Benzo(a)pyrene & 2.1 \\
\hline Benzo(b)fluoranthene & 2.29 \\
\hline Benzo(k)fluoranthene & 22.5 \\
\hline Benz(a)anthracene & $\mathbf{0 . 6 8}$ \\
\hline Chrysene & $\mathbf{6 9}$ \\
\hline Fluorene & $\mathbf{2 4 0}$ \\
\hline Fluoranthene & $\mathbf{1 4 0 0}$ \\
\hline Naphthalene & 21 \\
\hline Pyrene & $\mathbf{1 0 0 0}$ \\
\hline
\end{tabular}

Values in bold are current screening level values. 


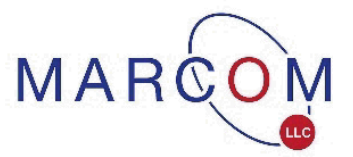

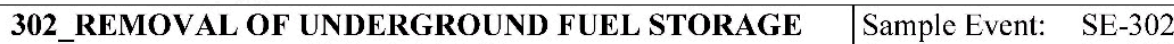

\begin{tabular}{l|l} 
TANKS_TAN & Page: $\quad 7$ of 10
\end{tabular}

\section{$3.4 \quad Q A / Q C$}

The sample receipt checklist shown that the methanol tubes for the soil kits were not added to the samples in the field. The lab Matrix Spike and Matrix Spike Duplicate test were done on an outside sample instead of on one of the samples from this project.

\subsection{Data Package}

A full data package was provided which included case narratives, chain of custody documentation, data and quality control summary.

\subsection{Sample Analysis Identification}

Table 5. Sample Analysis Identification.

\begin{tabular}{|l|l|l|l|l|}
\hline Laboratory ID & MarCom ID & Matrix & Line-Item Code & Method \\
\hline 528429001 & Field Blank & Water & SVO-A-008 & SW-846 8270 SIM \\
\hline 528429002 & TANN20006 & Soil & SVO-A-009 & SW-846 8270 SIM \\
\hline 528429002 & TANN20006 & Soil & VOA-A-003 & SW-846 5035B \\
\hline 528429002 & TANN20006 & Soil & VOA-A-008 & SW-846 8260 \\
\hline 528429003 & TANN20007 & Soil & SVO-A-009 & SW-846 8270 SIM \\
\hline 528429003 & TANN20007 & Soil & VOA-A-003 & SW-846 5035B \\
\hline 528429003 & TANN20007 & Soil & VOA-A-008 & SW-846 8260 \\
\hline 528429004 & TANN20008 & Soil & SVO-A-009 & SW-846 8270 SIM \\
\hline 528429004 & TANN20008 & Soil & VOA-A-003 & SW-846 5035B \\
\hline 528429004 & TANN20008 & Soil & VOA-A-008 & SW-846 8260 \\
\hline 528429005 & TANN20009 & Soil & SVO-A-009 & SW-846 8270 SIM \\
\hline 528429005 & TANN20009 & Soil & VOA-A-003 & SW-846 5035B \\
\hline 528429005 & TANN20009 & Soil & VOA-A-008 & SW-846 8260 \\
\hline 528429006 & TANN20010 & Soil & SVO-A-009 & SW-846 8270 SIM \\
\hline 528429006 & TANN20010 & Soil & VOA-A-003 & SW-846 5035B \\
\hline 528429006 & TANN20010 & Soil & VOA-A-008 & SW-846 8260 \\
\hline 528429008 & Trip Blank & Water & VOA-A-007 & SW-486 8260 \\
\hline
\end{tabular}

\section{CLOSE OUT COMMENTS}




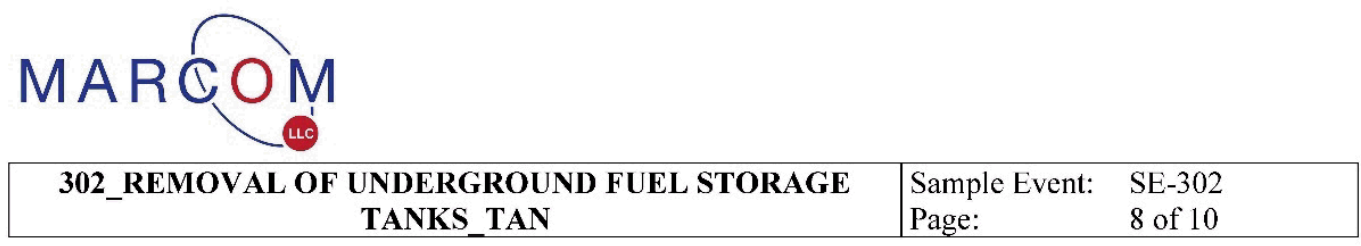

\section{REFERENCES/TRAINING REQUIREMENTS}

IDEQ, 2018. Idaho Risk Evaluation Manual for Petroleum Releases, Boise Idaho.

IDEQ, Fact Sheet: How DEQ Evaluates Sample Collection and Data Analysis for UST Closures and Release Investigations. Retrieved on 12-4-2020 from https://www.deq.idaho.gov/media/60180049/howdeq-evaluates-sample-collection-data-analysis-used-oil-ust-closures-releases.pdf 


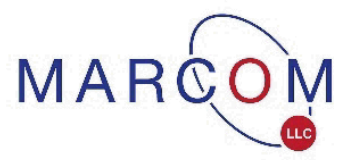

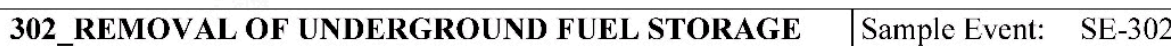

TANKS_TAN $\quad$ Page: 9 of 10

\title{
APPENDIX A FREQUENTLY USED ACRONYMS
}

\author{
Since acronyms are commonly used in lab documents, acronyms will not be defined throughout the \\ document itself. This list is provided as a reference for frequently used acronyms in sampling event \\ narratives. Not all acronyms will be used. This list may not be all inclusive. If an acronym is used that is \\ not included on this list, every effort will be made to define it within the narrative.

$\begin{array}{ll}\text { Ag } & \text { Silver } \\ \text { AL } & \text { Analytical Laboratory } \\ \text { As } & \text { Arsenic } \\ \text { ATR } & \text { Advanced Test Reactor } \\ \text { Ba } & \text { Barium } \\ \text { Be } & \text { Beryllium } \\ \text { BEA } & \text { Battelle Energy Alliance } \\ \text { Cd } & \text { Cadmium } \\ \text { CERCLA } & \text { Comprehensive Environmental Response, Compensation, and Liability Act } \\ \text { CFR } & \text { Code Federal Regulations } \\ \text { Cr } & \text { Chromium } \\ \text { CSU } & \text { Combined Standard Uncertainty } \\ \text { Dup } & \text { Duplicate } \\ \text { EPA } & \text { Environmental Protection Agency } \\ \text { G\&A } & \text { General and Administrative Expense } \\ \text { GEL } & \text { GEL Laboratories, LLC } \\ \text { HDPE } & \text { High Density Polyethylene } \\ \text { HFEF } & \text { Hot Fuel Examination Facility } \\ \text { Hg } & \text { Mercury } \\ \text { IDAPA } & \text { Idaho Administrative Procedure Act } \\ \text { INL } & \text { Idaho National Laboratory } \\ \text { LCS } & \text { Laboratory Control Sample } \\ \text { MDC } & \text { Minimum Detectable Concentration } \\ \text { MFC } & \text { Material Fuels Complex } \\ \text { MS } & \text { Matrix Spike } \\ \text { MSD } & \text { Matrix Spike Duplicates } \\ \text { NA } & \text { Not Available } \\ \text { NEPA } & \text { National Environmental Policy Act } \\ \text { Ni } & \text { Nickel } \\ \text { P\&T } & \text { Packing \& Transportation } \\ & \end{array}$




\begin{tabular}{|c|c|}
\hline \multicolumn{2}{|c|}{$\begin{array}{l}\text { 302_REMOVAL OF UNDERGROUND FUEL STORAC } \\
\text { TANKS_TAN }\end{array}$} \\
\hline $\mathrm{Pb}$ & Lead \\
\hline PCBs & Polychlorinated biphenyls \\
\hline PCDDs & Polychlorinated dibenzo-dioxins \\
\hline PCDFs & Polychlorinated dibenzo Furans \\
\hline ppb & Parts per Billion \\
\hline ppm & Parts per Million \\
\hline $\mathrm{QA} / \mathrm{QC}$ & Quality Assurance/Quality Control \\
\hline RadCon & Radiological Controls \\
\hline RCRA & Resource Conservation and Recovery Act \\
\hline RML & Radiation Measurements Laboratory \\
\hline RSD & Relative Standard Deviation \\
\hline $\mathrm{Sb}$ & Antimony \\
\hline SE & Sampling Event \\
\hline $\mathrm{Se}$ & Selenium \\
\hline SVOAs & Semi-Volatile Organic Analysis \\
\hline TCLP & Toxicity Characteristic Leaching Procedure \\
\hline $\mathrm{Tl}$ & Thallium \\
\hline TOS & Task-Order Statement of Work \\
\hline TREAT & Transient Reactor Test \\
\hline UTS & Universal Treatment Standards \\
\hline V & Vanadium \\
\hline VOAs & Volatile Organic Analysis \\
\hline WO & Work Order \\
\hline $\mathrm{Zn}$ & Zinc \\
\hline
\end{tabular}

\section{Appendix E - Sample Analytical Report TOS-302 Gel Laboratories Data}




\section{Package}

GEL Laboratories LLC

a member of The GEL Group INC
PO Box 30712 Charleston, SC 29417 2040 Savage Road Charleston, SC 29407

P 843.556 .8171

F 843.766 .1178

gel.com

November 25, 2020

Ms. Kim Archibald

MarCom, LLC

$506 \mathrm{~S}$. Woodruff

Idaho Falls, Idaho 83401

Re: Analytical for

Work Order: 528429

Dear Ms. Archibald:

GEL Laboratories, LLC (GEL) appreciates the opportunity to provide the enclosed analytical results for the sample(s) we received on November 24, 2020. This original report has been prepared and reviewed in accordance with GEL's standard operating procedures.

Test results for NELAP or ISO 17025 accredited tests are verified to meet the requirements of those standards, with any exceptions noted. The results reported relate only to the items tested and to the sample as received by the laboratory. These results may not be reproduced except as full reports without approval by the laboratory. Copies of GEL's accreditations and certifications can be found on our website at www.gel.com.

Our policy is to provide high quality, personalized analytical services to enable you to meet your analytical needs on time every time. We trust that you will find everything in order and to your satisfaction. If you have any questions, please do not hesitate to call me at (843) 556-8171, ext. 4487.

Sincerely,

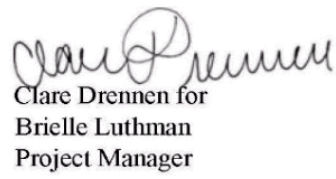

Purchase Order: 23270002P01TOS302

Chain of Custody: 259

Enclosures 


\section{Table of Contents}

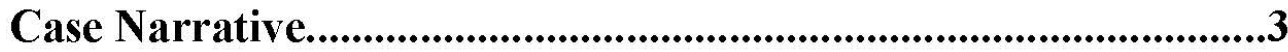

Chain of Custody and Supporting Documentation...........................6

Data Review Qualifier Definitions..................................................10

Laboratory Certifications.................................................................13

Volatile Analysis...................................................................................15

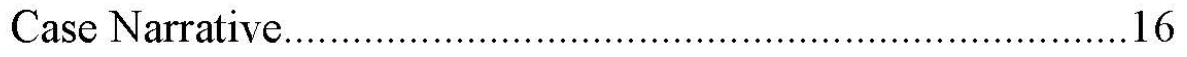

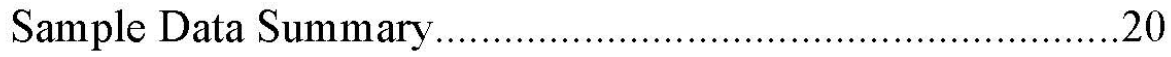

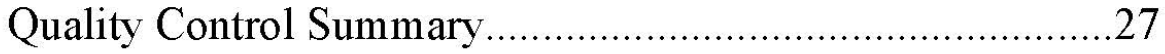

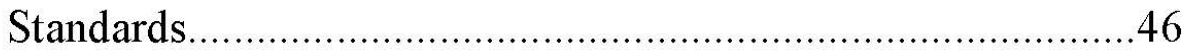

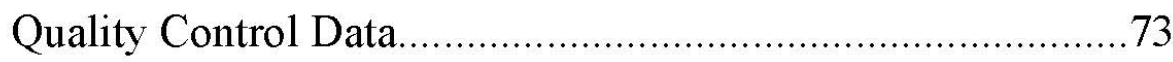

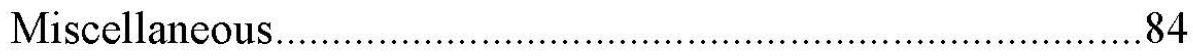

Semi-Volatile Analysis........................................................................92

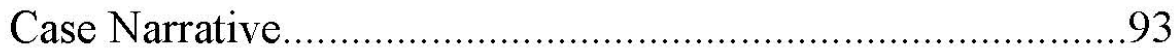

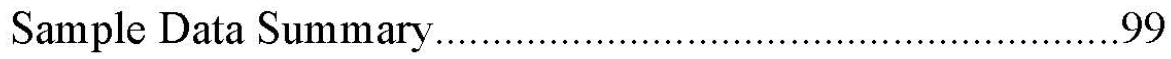

Quality Control Summary ..................................................106

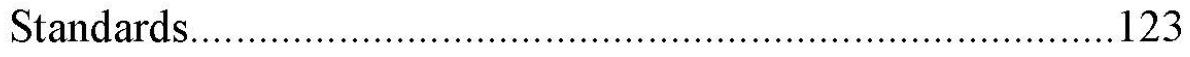

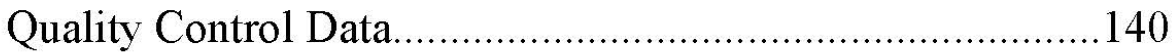

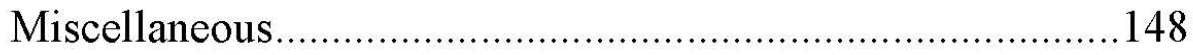




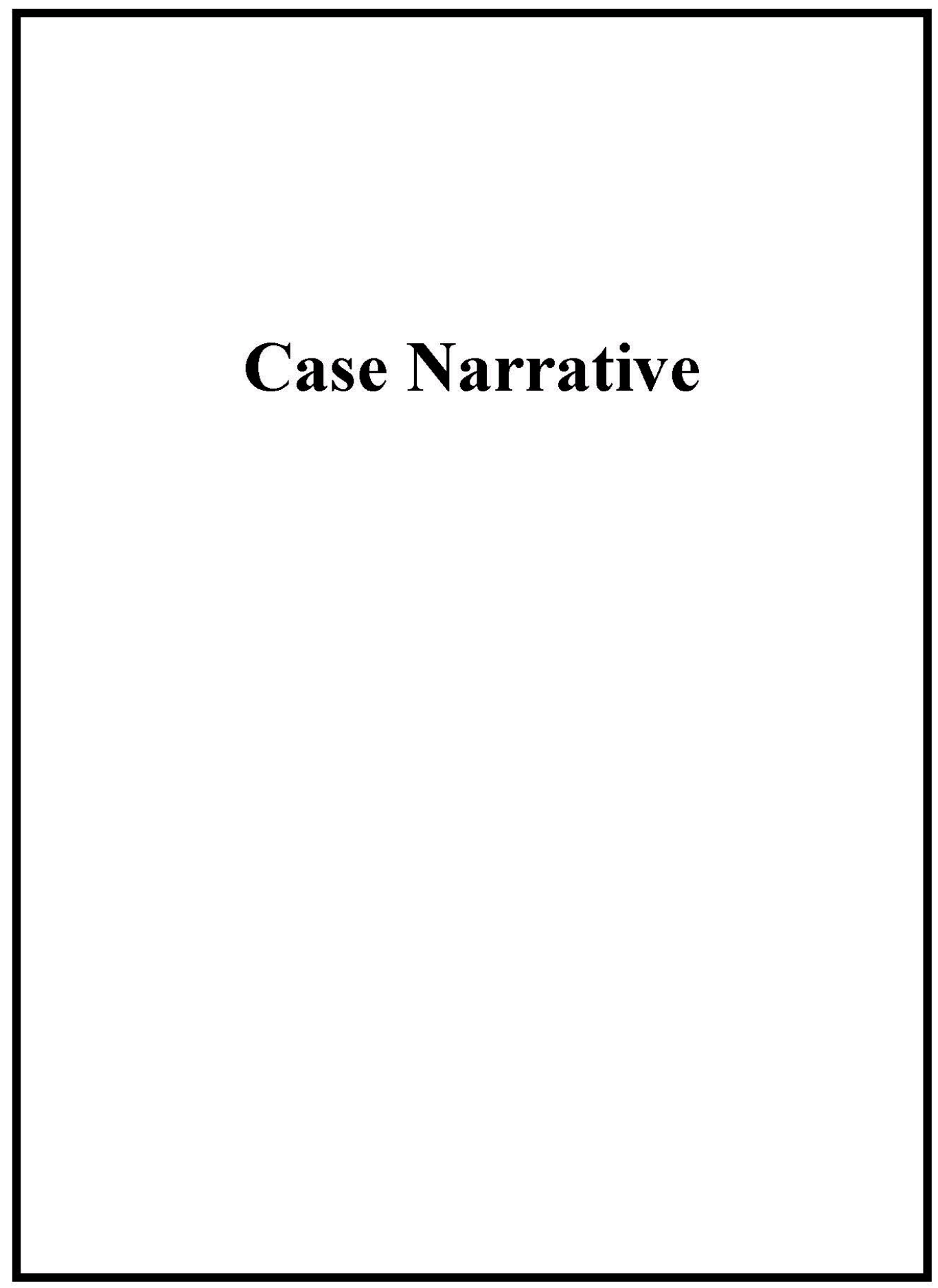

Page 1 of 151 SDG: 528429 


\section{Case Narrative \\ for \\ Marcom LLC \\ SDG: $\mathbf{5 2 8 4 2 9}$}

November 25, 2020

Laboratory Identification:

GEL Laboratories LLC

2040 Savage Road

Charleston, South Carolina 29407

(843) $556-8171$

TOS

Analytical for

\section{Project Title}

302_COC

Summary:

Sample Receipt The samples arrived at GEL Laboratories LLC, Charleston, South Carolina on November 24, 2020 for analysis. The samples were delivered with proper chain of custody documentation and signatures. All sample containers arrived without any visible signs of tampering or breakage. Shipping container temperatures were checked, documented, and within specifications. There are no additional comments concerning sample receipt.

Items of Note There are no additional items of note concerning this SDG.

Sample Identification The laboratory received the following sample(s):

$\begin{array}{llll}\text { Laboratory ID } & \text { Client ID } & \text { Matrix } & \text { LIC } \\ 528429001 & \text { FIELD BLANK } & \text { Water } & \text { SVO-A-008 } \\ 528429002 & \text { TANN20006 } & \text { Soil } & \text { SVO-A-009 } \\ 528429002 & \text { TANN20006 } & \text { Soil } & \text { VOA-A-003 } \\ 528429002 & \text { TANN20006 } & \text { Soil } & \text { VOA-A-008 } \\ 528429003 & \text { TANN20007 } & \text { Soil } & \text { SVO-A-009 } \\ 528429003 & \text { TANN20007 } & \text { Soil } & \text { VOA-A-003 } \\ 528429003 & \text { TANN20007 } & \text { Soil } & \text { VOA-A-008 } \\ 528429004 & \text { TANN20008 } & \text { Soil } & \text { SVO-A-009 } \\ 528429004 & \text { TANN20008 } & \text { Soil } & \text { VOA-A-003 } \\ 528429004 & \text { TANN20008 } & \text { Soil } & \text { VOA-A-008 } \\ 528429005 & \text { TANN20009 } & \text { Soil } & \text { SVO-A-009 }\end{array}$




$\begin{array}{llll}528429005 & \text { TANN20009 } & \text { Soil } & \text { VOA-A-003 } \\ 528429005 & \text { TANN20009 } & \text { Soil } & \text { VOA-A-008 } \\ 528429006 & \text { TANN20010 } & \text { Soil } & \text { SVO-A-009 } \\ 528429006 & \text { TANN20010 } & \text { Soil } & \text { VOA-A-003 } \\ 528429006 & \text { TANN20010 } & \text { Soil } & \text { VOA-A-008 } \\ 528429007 & \text { TRIP BLANK } & \text { Water } & \text { VOA-A-007 }\end{array}$

\section{Case Narrative}

Sample analyses were conducted using methodology as outlined in GEL Laboratories, LLC (GEL) Standard Operating Procedures. Any technical or administrative problems during analysis, data review, and reduction are contained in the analytical case narratives in the enclosed data package.

\section{Prep Methods and Prep Dates}

\section{Method $\quad$ Run Date ID}

SW8463510C

SW846 3541

SW846 5035A

\section{Analysis Methods and Analysis Dates}

\section{Method Run Date ID}

\section{Certification Statement}

I certify that this data package is in compliance with the terms and conditions of SOW-0062 and any applicable TOSs for this project, both technically and for completeness, for other than the conditions detailed in this case narrative. Release of the data contained in this data package and also in any associated computer-readable data submitted has been authorized by the laboratory manager or manager's designee.

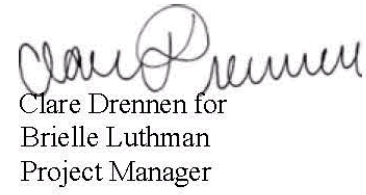




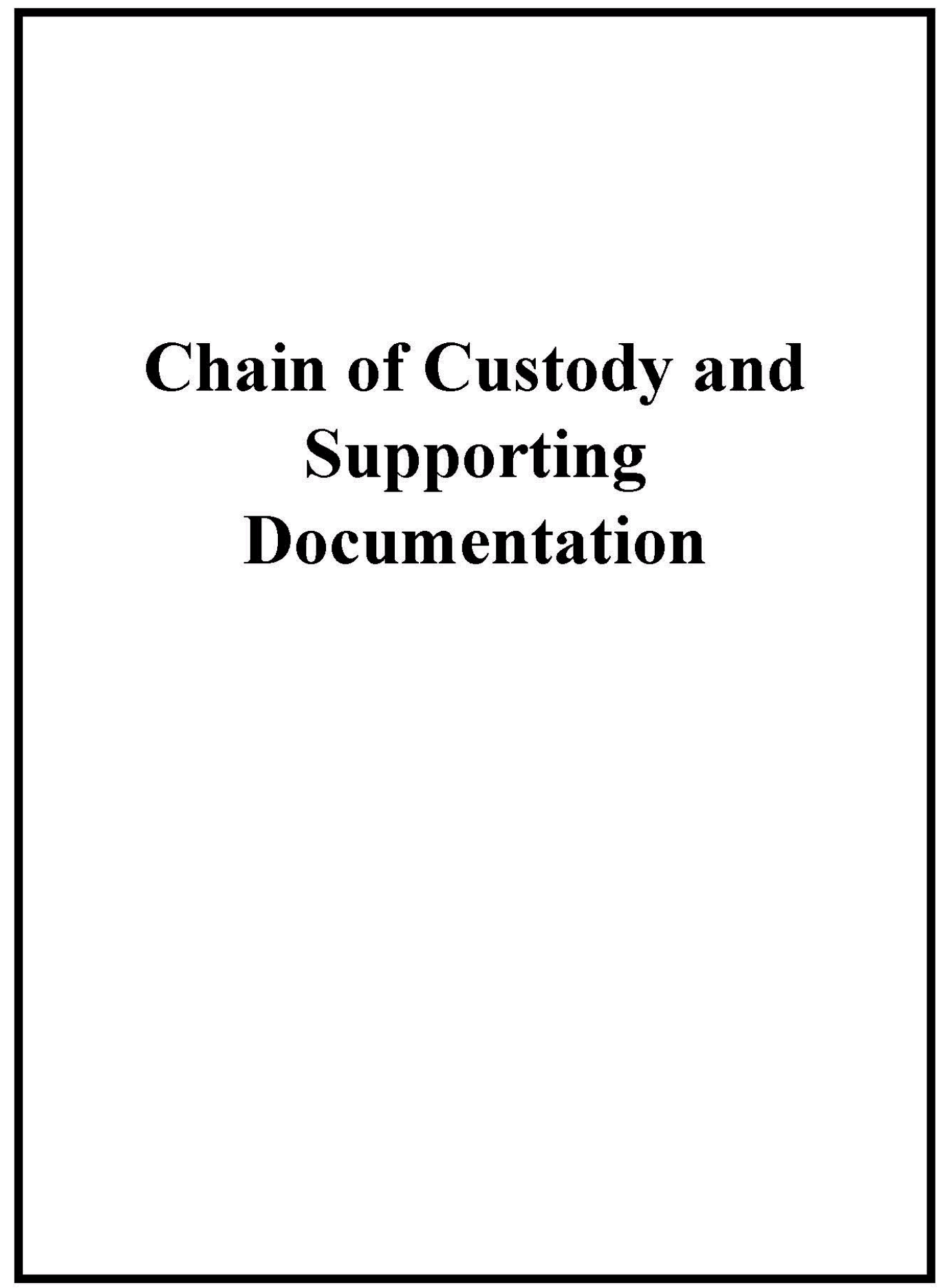

Page 4 of 151 SDG: 528429 


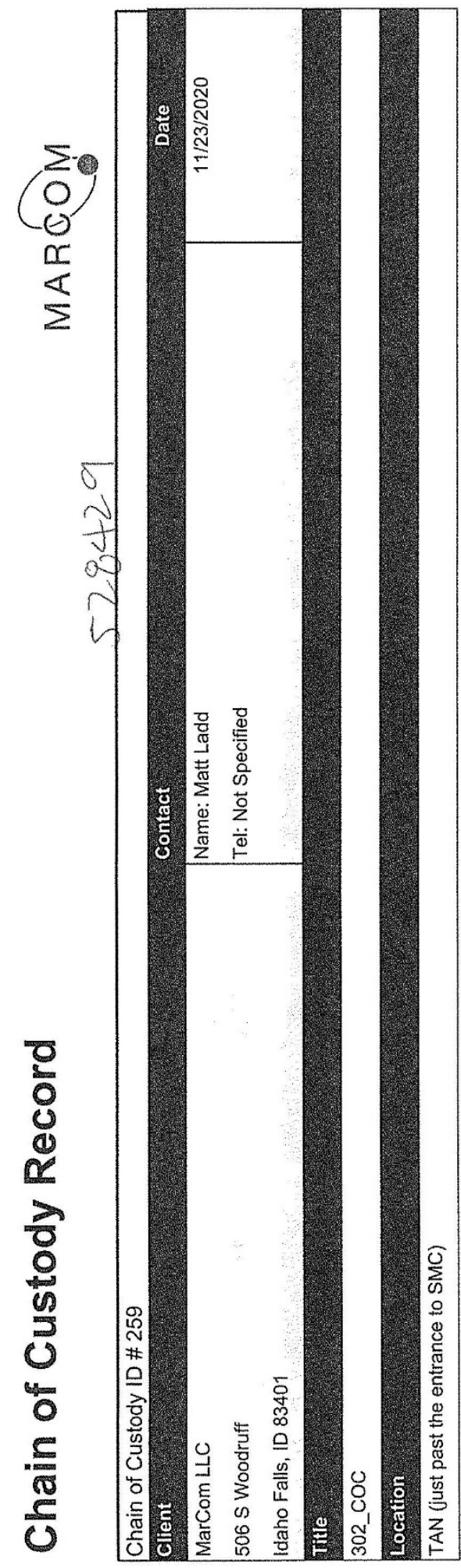

Page 5 of 151 SDG: 528429
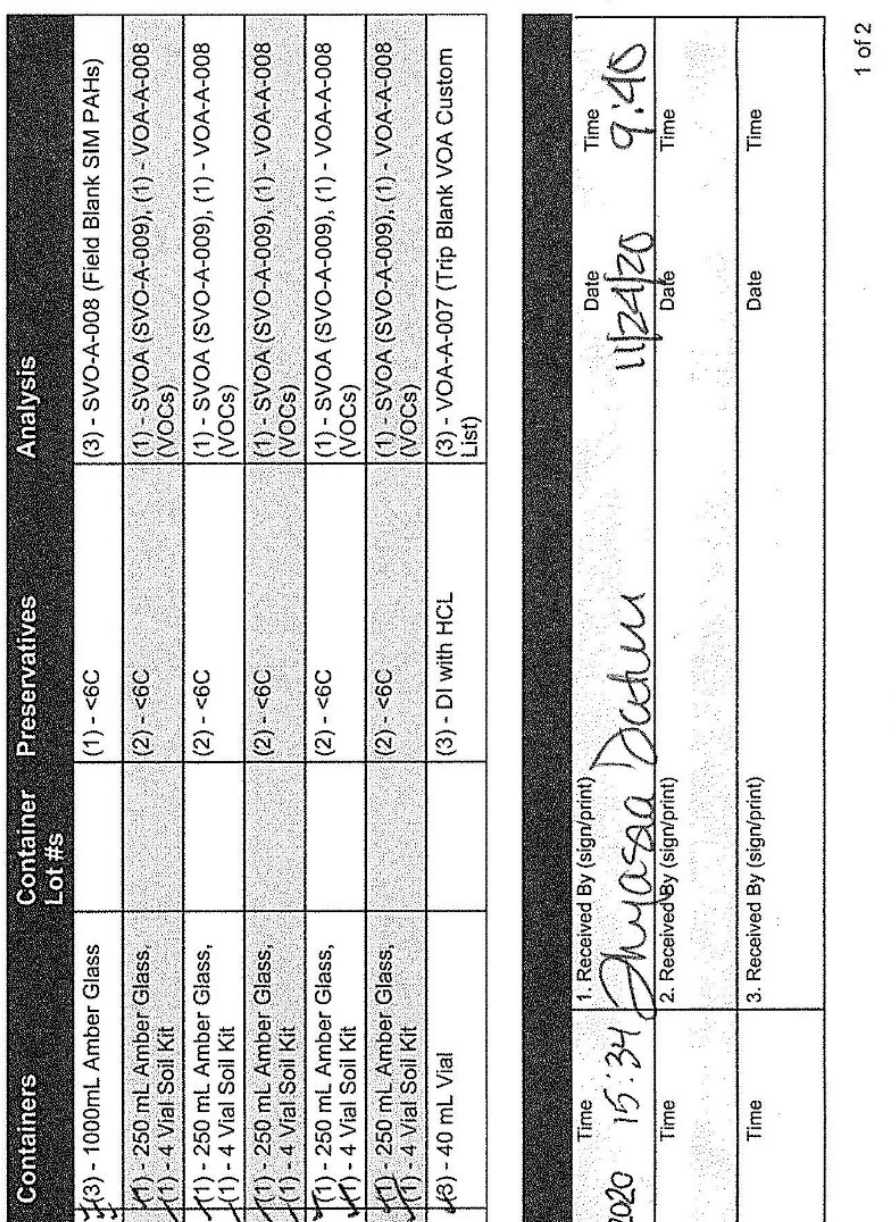

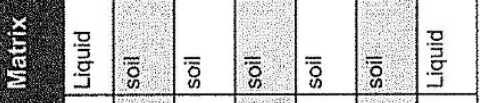

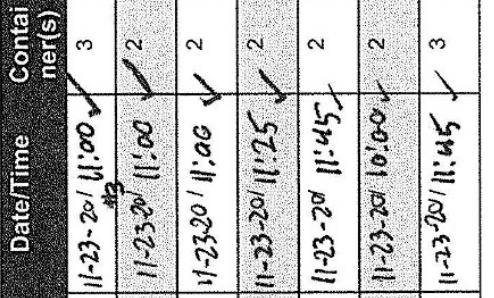

*

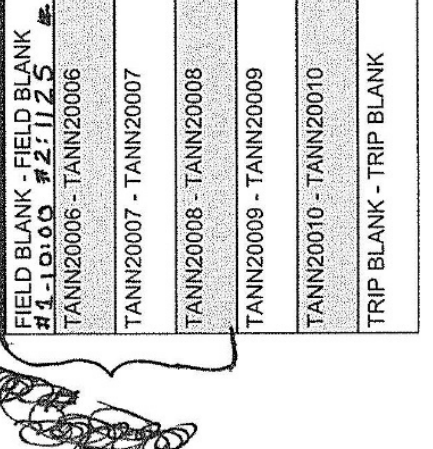

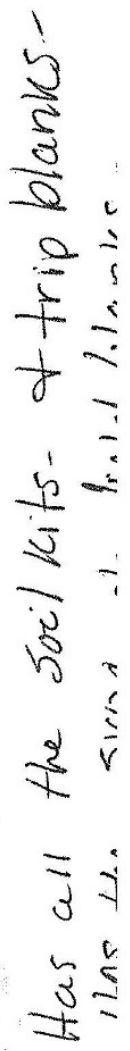

Ho

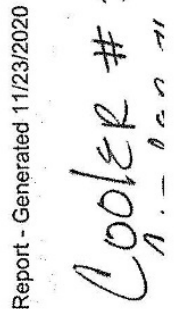



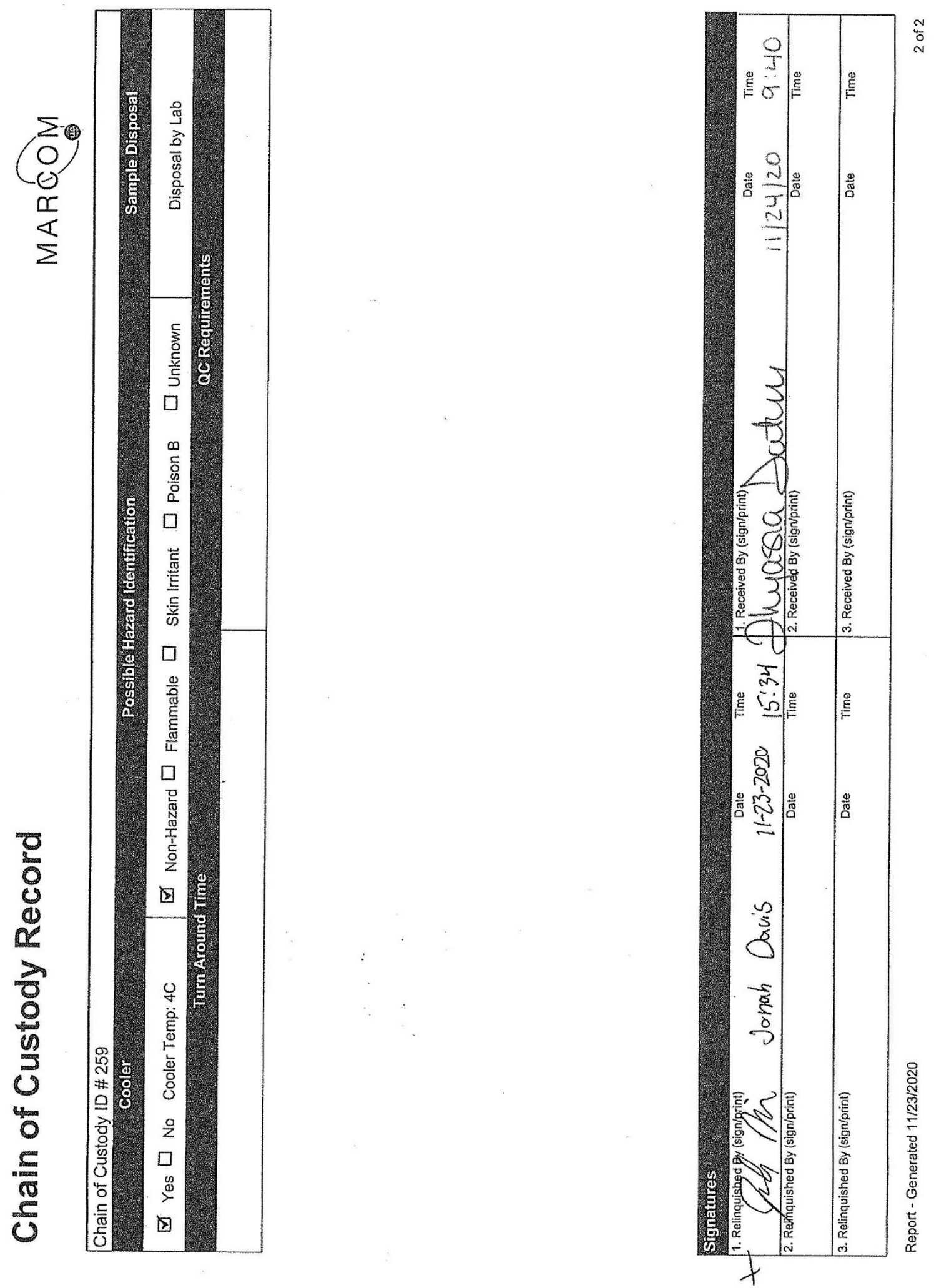

Page 6 of 151 SDG: 528429 


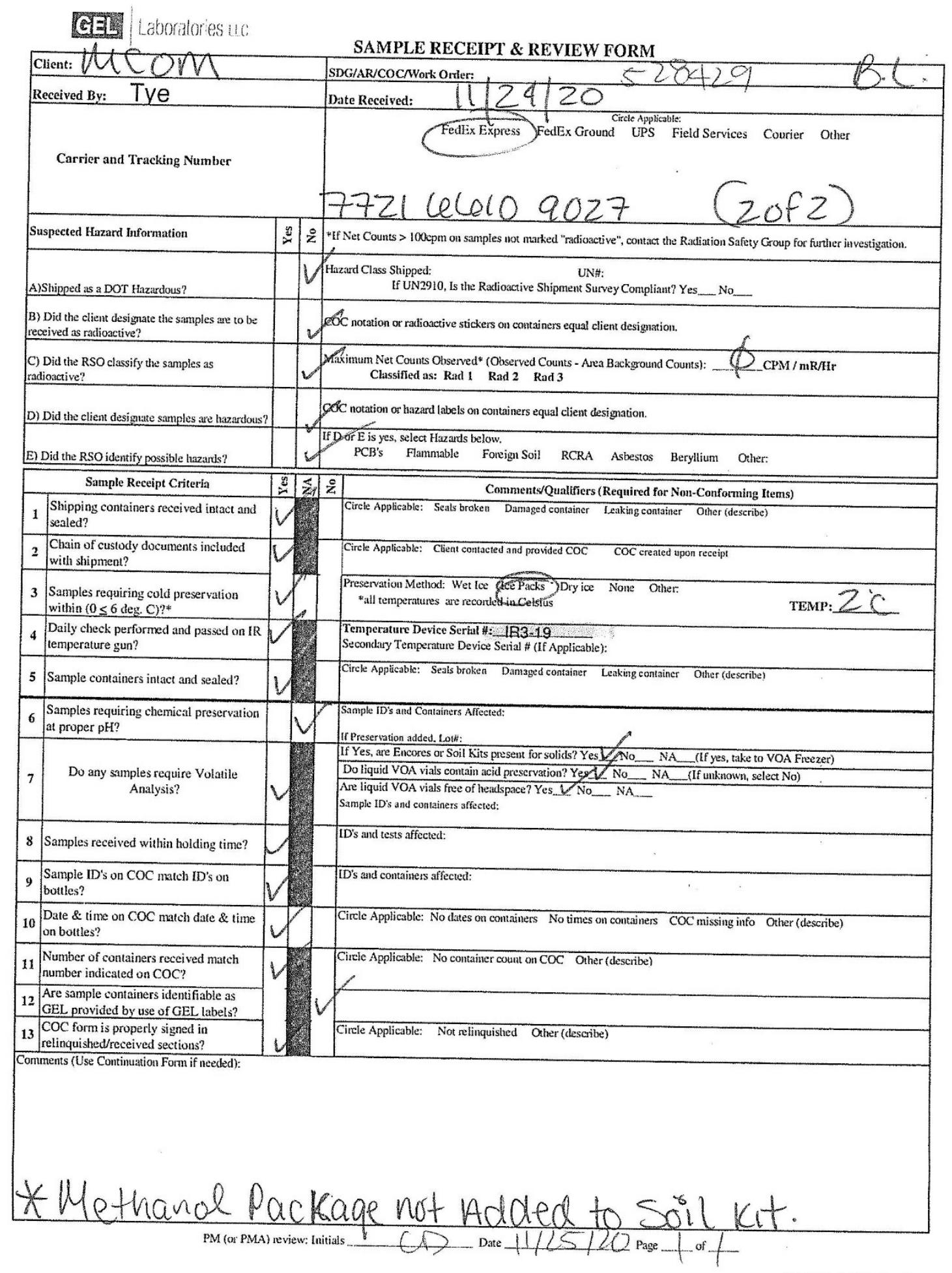

GL-CHL-SR-001 Rev 7

Page 7 of 151 SDG: 528429 


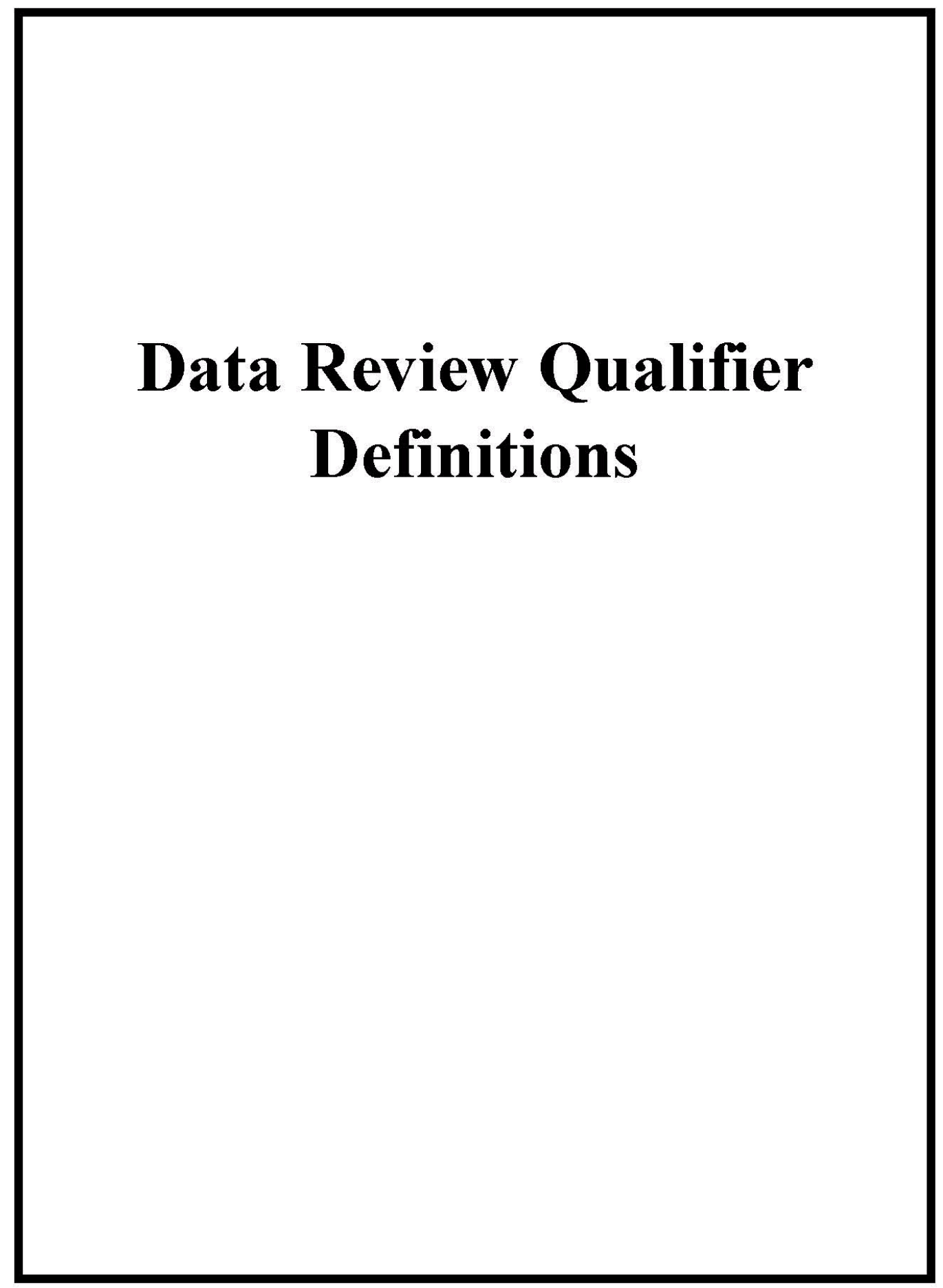

Page 8 of 151 SDG: 528429 


\section{Data Review Qualifier Definitions}

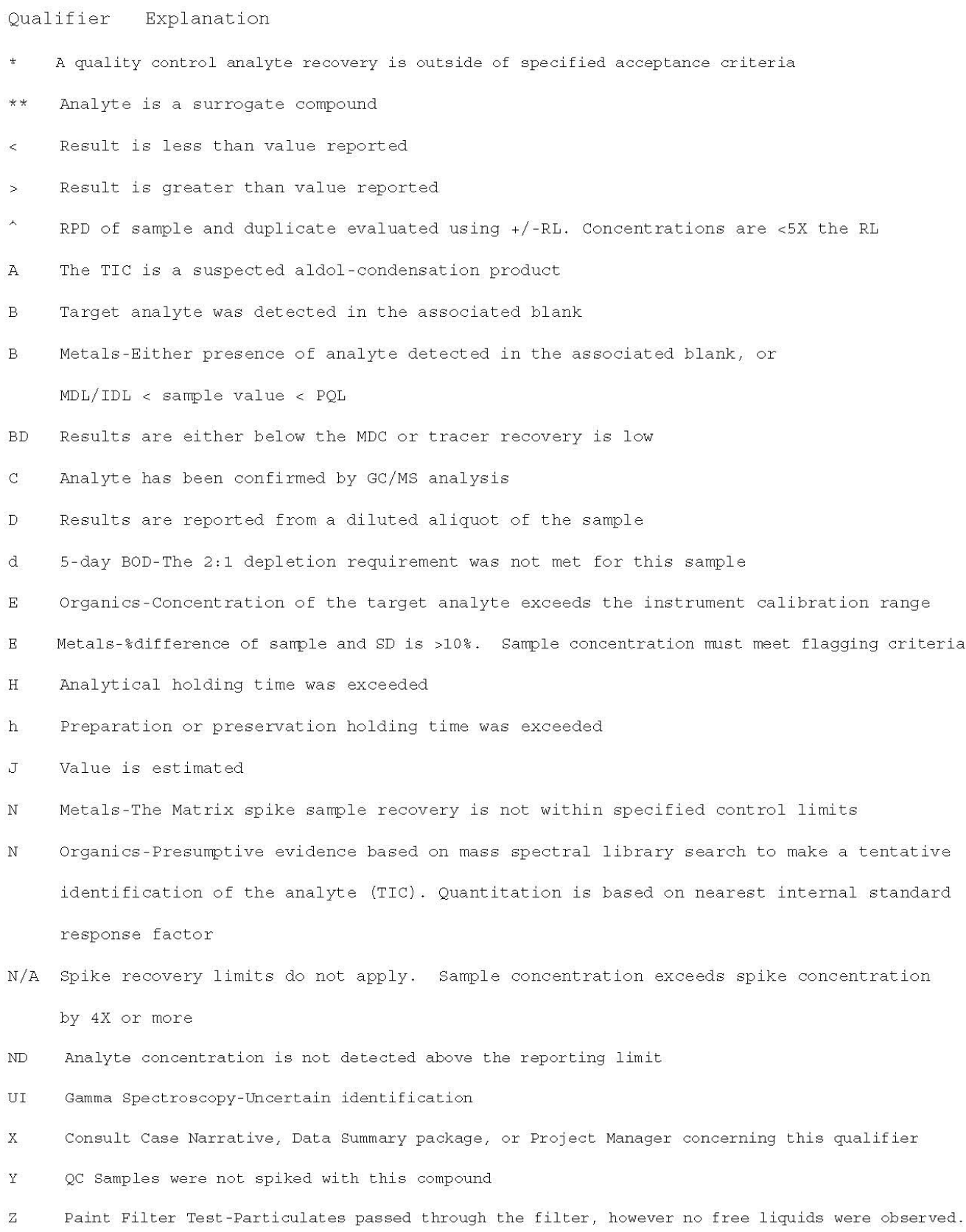

Page 9 of 151 SDG: 528429 
Organics-The concentrations between the primary and confirmation columns/detectors is $>40 \%$ difference.

For HPLC, the difference is $>70 \%$.

U Analyte was analyzed for, but not detected above the MDL, MDA, or LOD.

Page 10 of 151 SDG: 528429 


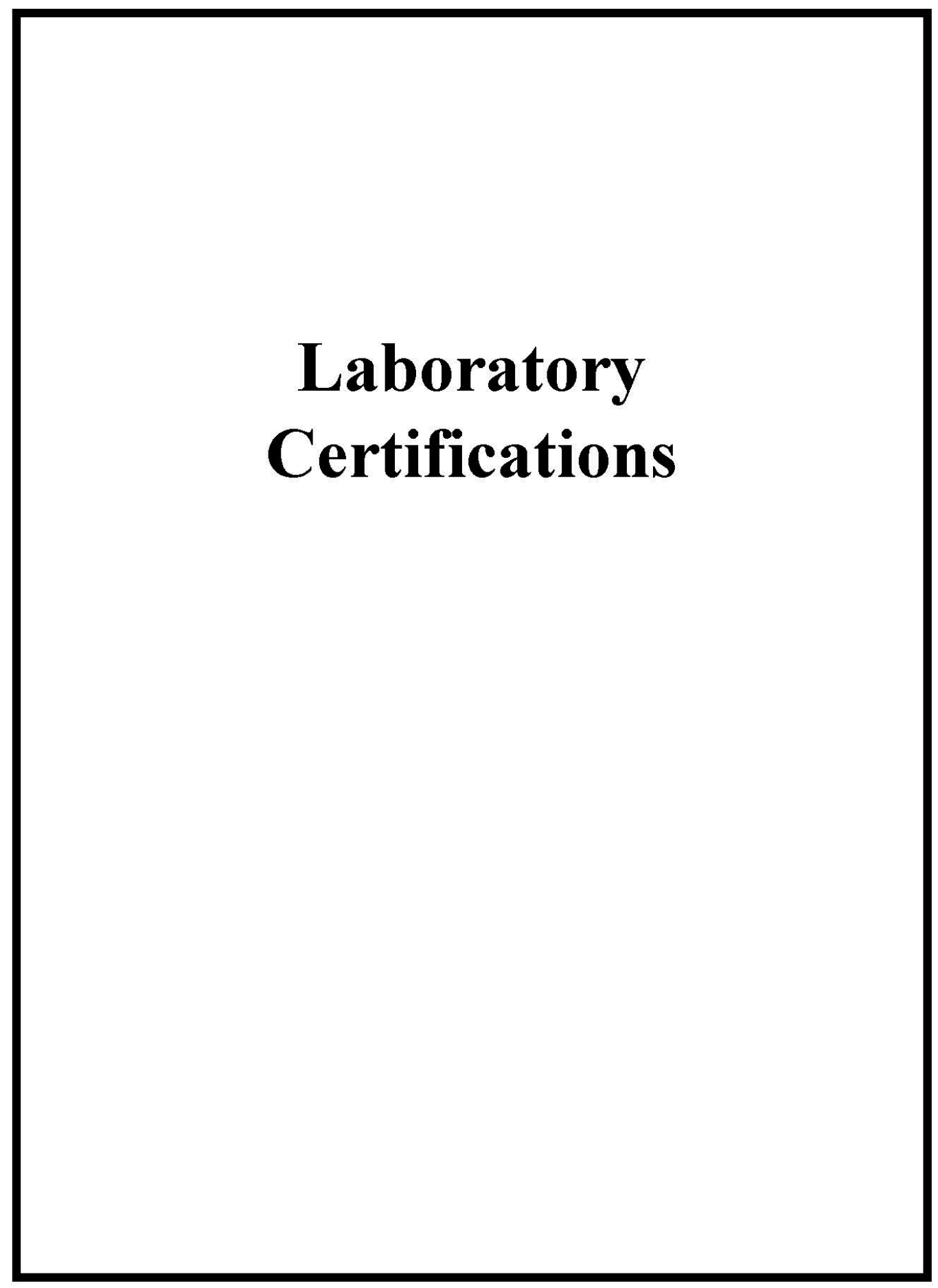

Page 11 of 151 SDG: 528429 
List of current GEL Certifications as of 25 November 2020

\begin{tabular}{|c|c|}
\hline State & Certification \\
\hline Alabama & 42200 \\
\hline Alaska & $17-018$ \\
\hline Alaska Drinking Water & SC00012 \\
\hline Arkansas & $88-0651$ \\
\hline CLIA & 42D0904046 \\
\hline California & 2940 \\
\hline Colorado & $\mathrm{SC} 00012$ \\
\hline Connecticut & PH-0169 \\
\hline DoD ELAP/ ISO17025 A2LA & 2567.01 \\
\hline Florida NELAP & $\mathrm{E} 87156$ \\
\hline Foreign Soils Permit & P330-15-00283, P330-15-00253 \\
\hline Georgia & SC00012 \\
\hline Georgia SDWA & 967 \\
\hline Hawaii & SC00012 \\
\hline Idaho & SC00012 \\
\hline Illinois NELAP & 200029 \\
\hline Indiana & $\mathrm{C}-\mathrm{SC}-01$ \\
\hline Kansas NELAP & $E-10332$ \\
\hline Kentucky SDWA & 90129 \\
\hline Kentucky Wastewater & 90129 \\
\hline Louisiana Drinking Water & LA024 \\
\hline Louisiana NELAP & 03046 (AI33904) \\
\hline Maine & 2019020 \\
\hline Maryland & 270 \\
\hline Massachusetts & $\mathrm{M}-\mathrm{SC} 012$ \\
\hline Massachusetts PFAS Approv & Letter \\
\hline Michigan & 9976 \\
\hline Mississippi & SC00012 \\
\hline Nebraska & NE-OS-26-13 \\
\hline Nevada & SC000122021-1 \\
\hline New Hampshire NELAP & 2054 \\
\hline New Jersey NELAP & $\mathrm{SC002}$ \\
\hline New Mexico & SC00012 \\
\hline New York NELAP & 11501 \\
\hline North Carolina & 233 \\
\hline North Carolina SDWA & 45709 \\
\hline North Dakota & $\mathrm{R}-158$ \\
\hline Oklahoma & $2019-165$ \\
\hline Pennsylvania NELAP & $68-00485$ \\
\hline Puerto Rico & SC00012 \\
\hline S. Carolina Radiochem & 10120002 \\
\hline Sanitation Districts of L & 9255651 \\
\hline South Carolina Chemistry & 10120001 \\
\hline Tennessee & TN 02934 \\
\hline Texas NELAP & T104704235-20-17 \\
\hline Utah NELAP & SC000122020-33 \\
\hline Vermont & VT87156 \\
\hline Virginia NELAP & 460202 \\
\hline Washington & $\mathrm{C} 780$ \\
\hline
\end{tabular}

Page 12 of 151 SDG: 528429 


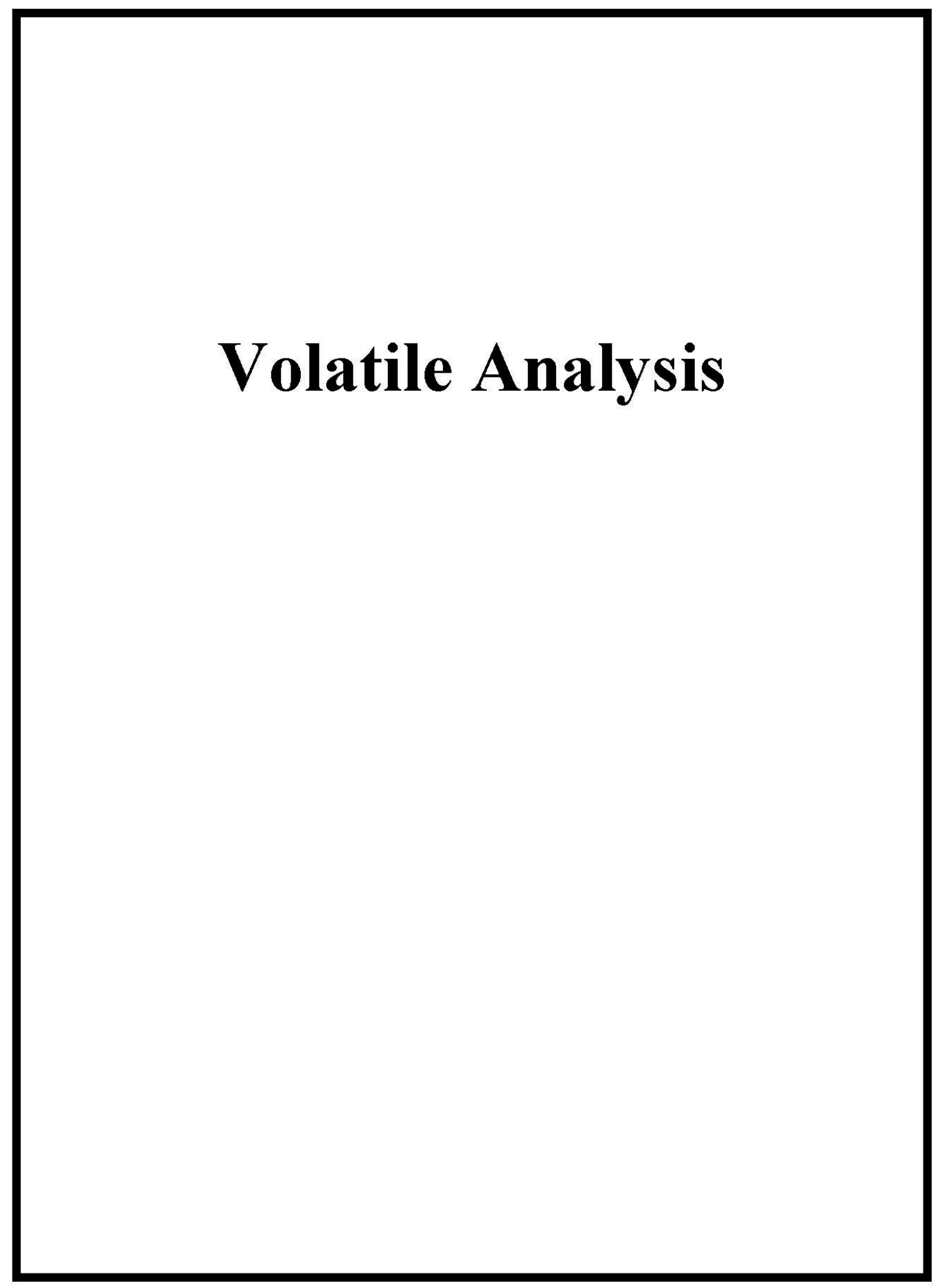

Page 13 of 151 SDG: 528429 


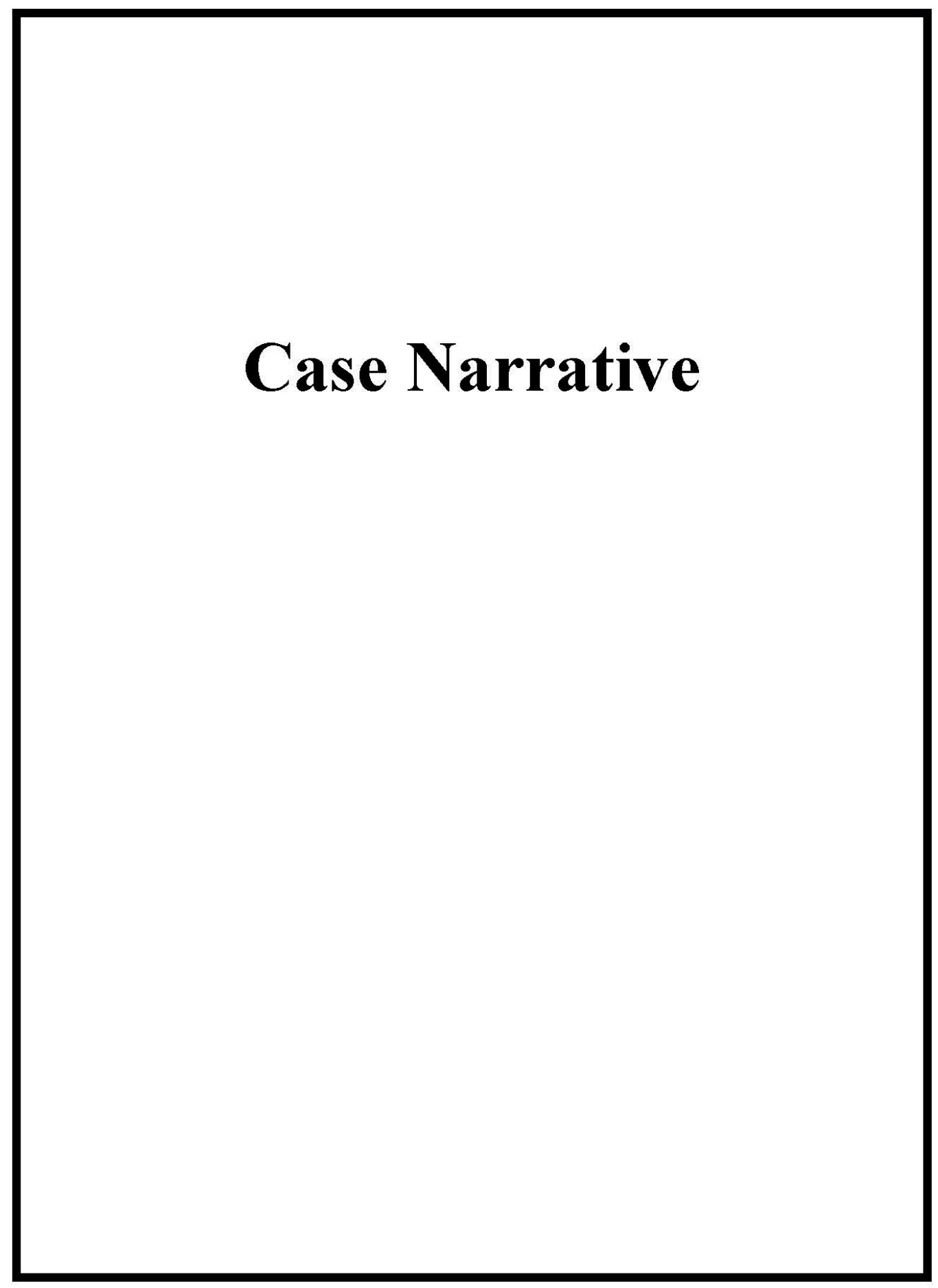

Page 14 of 151 SDG: 528429 


\title{
GC/MS Volatile \\ Technical Case Narrative \\ Marcom LLC \\ SDG \#: $\mathbf{5 2 8 4 2 9}$
}

\author{
Product: Volatile Organic Compounds (VOC) by Gas Chromatograph/Mass Spectrometer \\ Analytical Method: SW846 8260D \\ Analytical Procedure: GL-OA-E-038 REV\# 28 \\ Analytical Batches: 2067534 and 2067535 \\ Preparation Method: SW846 5035A \\ Preparation Procedure: GL-OA-E-039 REV\# 13 \\ Preparation Batch: 2067533
}

The following samples were analyzed using the above methods and analytical procedure(s).

\begin{tabular}{|c|c|}
\hline GEL Sample ID\# & Client Sample Identification \\
\hline 528429002 & TANN20006 \\
\hline 528429003 & TANN20007 \\
\hline 528429004 & TANN20008 \\
\hline 528429005 & TANN20009 \\
\hline 528429006 & TANN20010 \\
\hline 528429007 & TRIP BLANK \\
\hline 1204704445 & Method Blank (MB) \\
\hline 1204704446 & Method Blank (MB) \\
\hline 1204704448 & Laboratory Control Sample (LCS) \\
\hline 1204704449 & Laboratory Control Sample (LCS) \\
\hline 1204704450 & 528414001(NonSDG) Post Spike (PS) \\
\hline 1204704451 & 528414001(NonSDG) Post Spike Duplicate (PSD) \\
\hline 1204704452 & Method Blank (MB) \\
\hline 1204704454 & Laboratory Control Sample (LCS) \\
\hline 1204704456 & 527604007 (NonSDG) Post Spike (PS) \\
\hline 1204704457 & 527604007(NonSDG) Post Spike Duplicate (PSD) \\
\hline
\end{tabular}

Samples 528429002, 003, 004, 005 and 006 in this SDG were analyzed on a "dry weight corrected" basis. Sample 528429007 in this SDG was analyzed on an "as received" basis.

Data Summary:

All sample data provided in this report met the acceptance criteria specified in the analytical methods and procedures for initial calibration, continuing calibration, instrument controls and process controls where applicable, with the following exceptions.

\section{Calibration Information}

Continuing Calibration Verification Requirements

All Calibration Verification Standards (CCV) did not meet the acceptance criteria as outlined in Method 8260D for samples and the associated QC. However, the method allows for a designated number of outliers dependent on the requested analyte list. This SDG satisfied the $8260 \mathrm{D}$ outlier acceptance criteria. The results are reported.

\section{Certification Statement}

Page 15 of $151 \quad$ SDG: 528429 
Where the analytical method has been performed under NELAP certification, the analysis has met all of the requirements of the NELAC standard unless otherwise noted in the analytical case narrative.

Page 16 of 151 SDG: 528429 


\title{
GEL LABORA TORIES LLC
}

2040 Savage Road Charleston SC 29407 - (843)556-8171 - ww w gel com

\author{
Qualifier Definition Report \\ for
}

MCOM001 Marcom LLC

Client SDG: 528429 GEL Work Order: 528429

\section{The Qualifiers inthis report are defined as follows:}

*. A qualify control analyte recovery is outside of specified acceptance $a$ iteria

wak Arislyte is a surrogate compound

E Concertration of the target amalyte exceeds the instrmment calibration range

$U$ Analyte was amalyzed for, but not detected ab ove the MDL, MD A, MDC or L OD.

DL Indic ates that sample is dihted.

RA. Indic ates that sample is re-analyzed withoutre-extraction.

$\mathrm{RE}$ Indicates that sampl is re-extracted.

\section{Review/Vabiation}

GEL requires all analytical data to be verified by a qualif ied data reviewer. In addition, all CLP-like de liverables receive a thind level review of the fractional data package.

The following data walidator verified the information pre serted in this data report:

Signaure:




\section{Sample Data Summary}

Page 18 of 151 SDG: 528429 


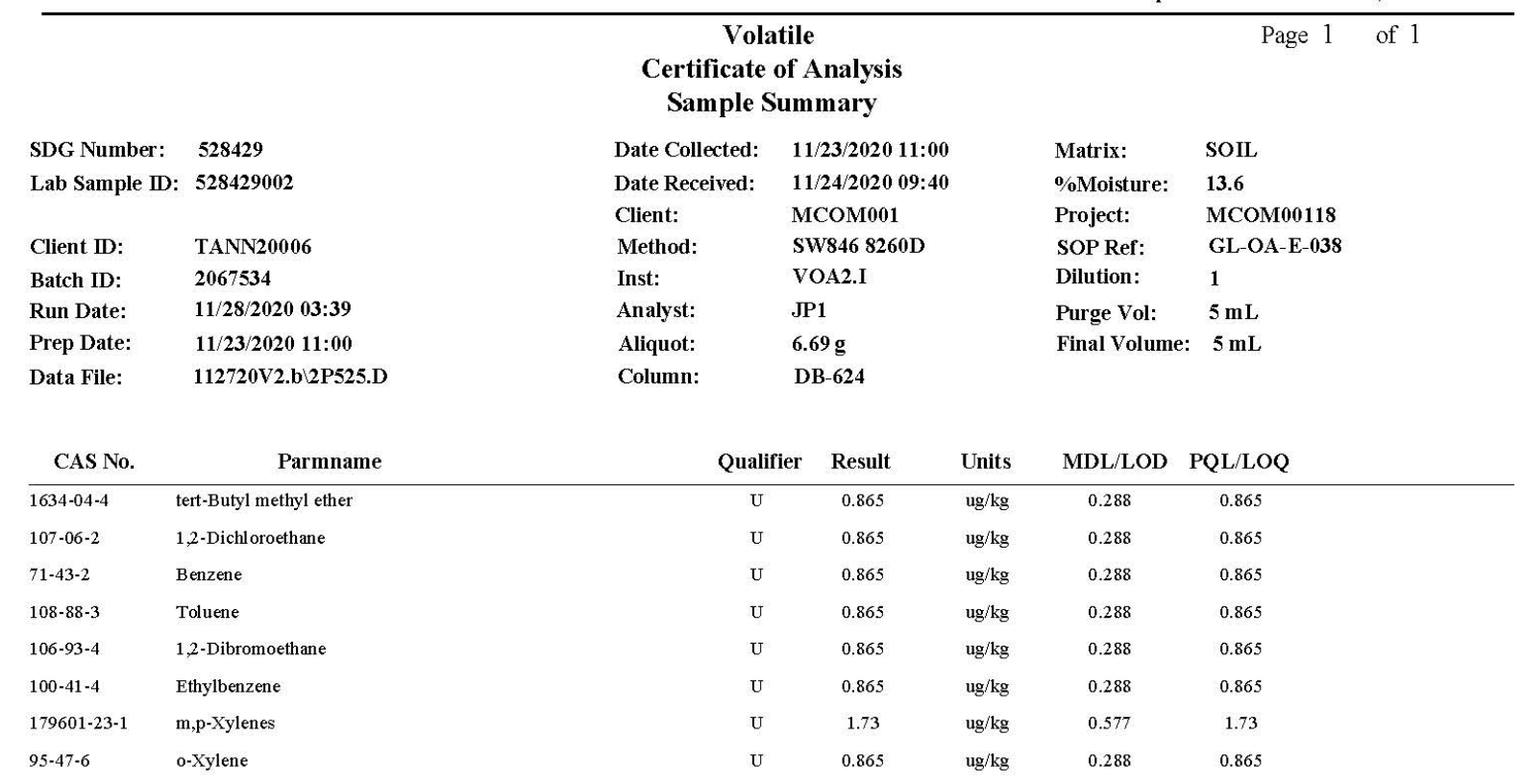

Page 19 of 151 SDG: 528429 


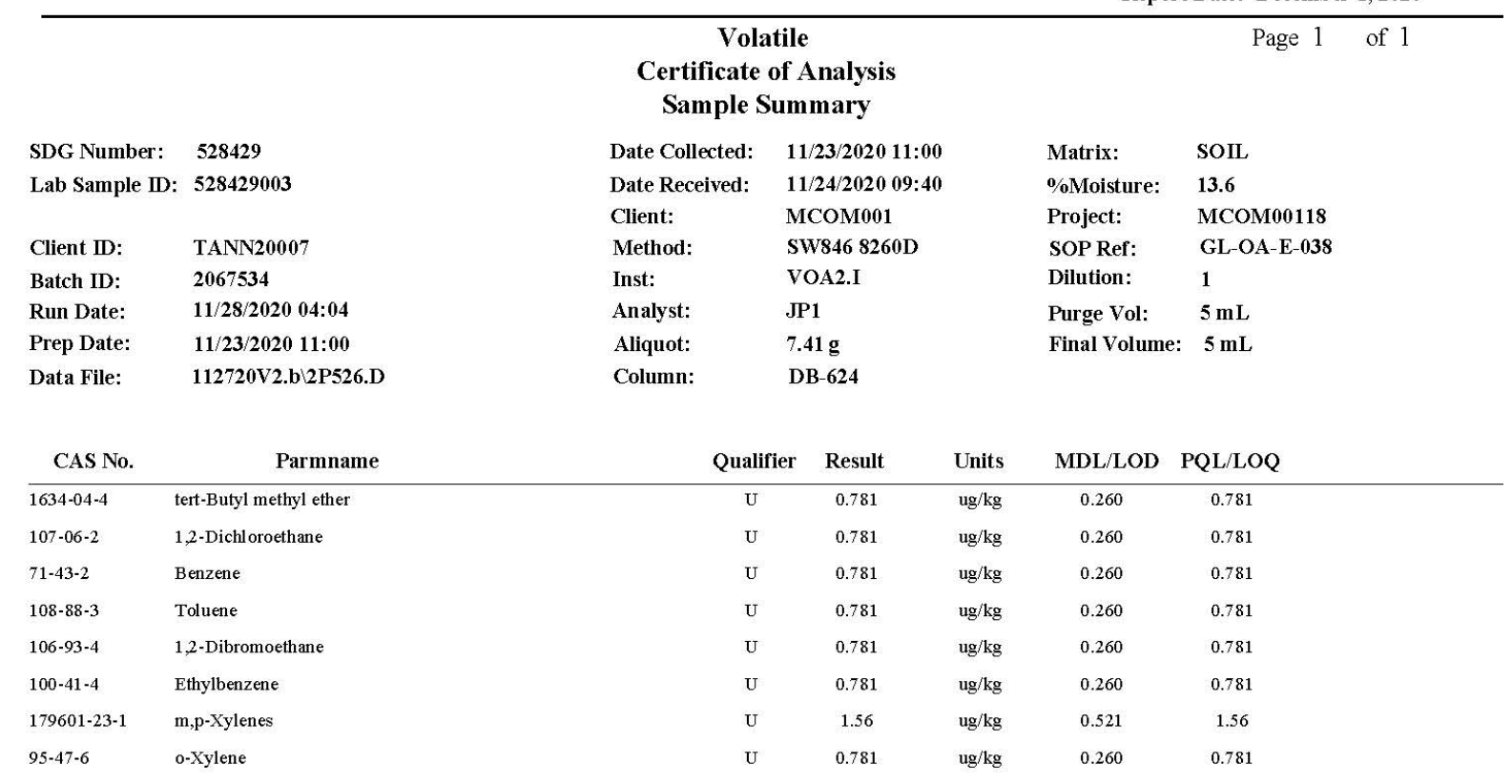

Page 20 of 151 SDG: 528429 


\begin{tabular}{|c|c|c|c|c|c|c|c|}
\hline \multicolumn{6}{|c|}{$\begin{array}{c}\text { Volatile } \\
\text { Certificate of Analysis } \\
\text { Sample Summary }\end{array}$} & \multicolumn{2}{|r|}{ Page 1 of 1} \\
\hline SDG Number: & \multirow{3}{*}{$\begin{array}{l}528429 \\
528429004\end{array}$} & Date Collected: & \multicolumn{3}{|c|}{$11 / 23 / 202011: 25$} & Matrix: & SOIL \\
\hline \multirow[t]{2}{*}{ Lab Sample ID: } & & Date Received: & \multicolumn{3}{|c|}{$11 / 24 / 202009: 40$} & \%Moisture: & 13.6 \\
\hline & & Client: & \multicolumn{3}{|c|}{ MCOM001 } & Project: & MCOM00118 \\
\hline Client ID: & TANN20008 & Method: & \multicolumn{3}{|c|}{ SW846 8260D } & SOP Ref: & GL-OA-E-038 \\
\hline Batch ID: & 2067534 & Inst: & \multicolumn{3}{|c|}{ VOA2.I } & Dilution: & 1 \\
\hline Run Date: & $11 / 28 / 202004: 31$ & Analyst: & \multicolumn{3}{|c|}{ JP1 } & \multirow{2}{*}{\multicolumn{2}{|c|}{$\begin{array}{ll}\text { Purge Vol: } & 5 \mathrm{~mL} \\
\text { Fin } & \end{array}$}} \\
\hline Prep Date: & $11 / 23 / 202011: 25$ & Aliquot: & \multicolumn{3}{|c|}{$5.87 \mathrm{~g}$} & & Final Volume: $5 \mathrm{~mL}$ \\
\hline Data File: & $112720 \mathrm{~V} 2 . \mathrm{b} \backslash 2 \mathrm{P} 527 . \mathrm{D}$ & Column: & \multicolumn{3}{|c|}{ DB-624 } & & \\
\hline CAS No. & Parmname & Quali & & Result & Units & $\mathrm{MDL} / \mathrm{LOD}$ & PQL/LOQ \\
\hline 1634-04-4 & tert-Butyl methyl ether & $\mathrm{U}$ & & 0.985 & $\mathrm{ug} / \mathrm{kg}$ & 0.328 & 0.985 \\
\hline $107-06-2$ & 1,2-Dichloroethane & $\mathrm{U}$ & & 0.985 & $\mathrm{ug} / \mathrm{kg}$ & 0.328 & 0.985 \\
\hline $71-43-2$ & Benzene & $\mathrm{U}$ & & 0.985 & $\mathrm{ug} / \mathrm{kg}$ & 0.328 & 0.985 \\
\hline $108-88-3$ & Toluene & $\mathrm{U}$ & & 0.985 & $\mathrm{ug} / \mathrm{kg}$ & 0.328 & 0.985 \\
\hline $106-93-4$ & 1,2-Dibromoethane & $\mathrm{U}$ & & 0.985 & $\mathrm{ug} / \mathrm{kg}$ & 0.328 & 0.985 \\
\hline $100-41-4$ & Ethylbenzene & $\mathrm{U}$ & & 0.985 & $\mathrm{ug} / \mathrm{kg}$ & 0.328 & 0.985 \\
\hline $179601-23-1$ & $\mathrm{~m}, \mathrm{p}$-Xylenes & $\mathrm{U}$ & & 1.97 & $\mathrm{ug} / \mathrm{kg}$ & 0.657 & 1.97 \\
\hline $95-47-6$ & o-Xylene & $\mathrm{U}$ & & 0.985 & $\mathrm{ug} / \mathrm{kg}$ & 0.328 & 0.985 \\
\hline
\end{tabular}

Page 21 of 151 SDG: 528429 


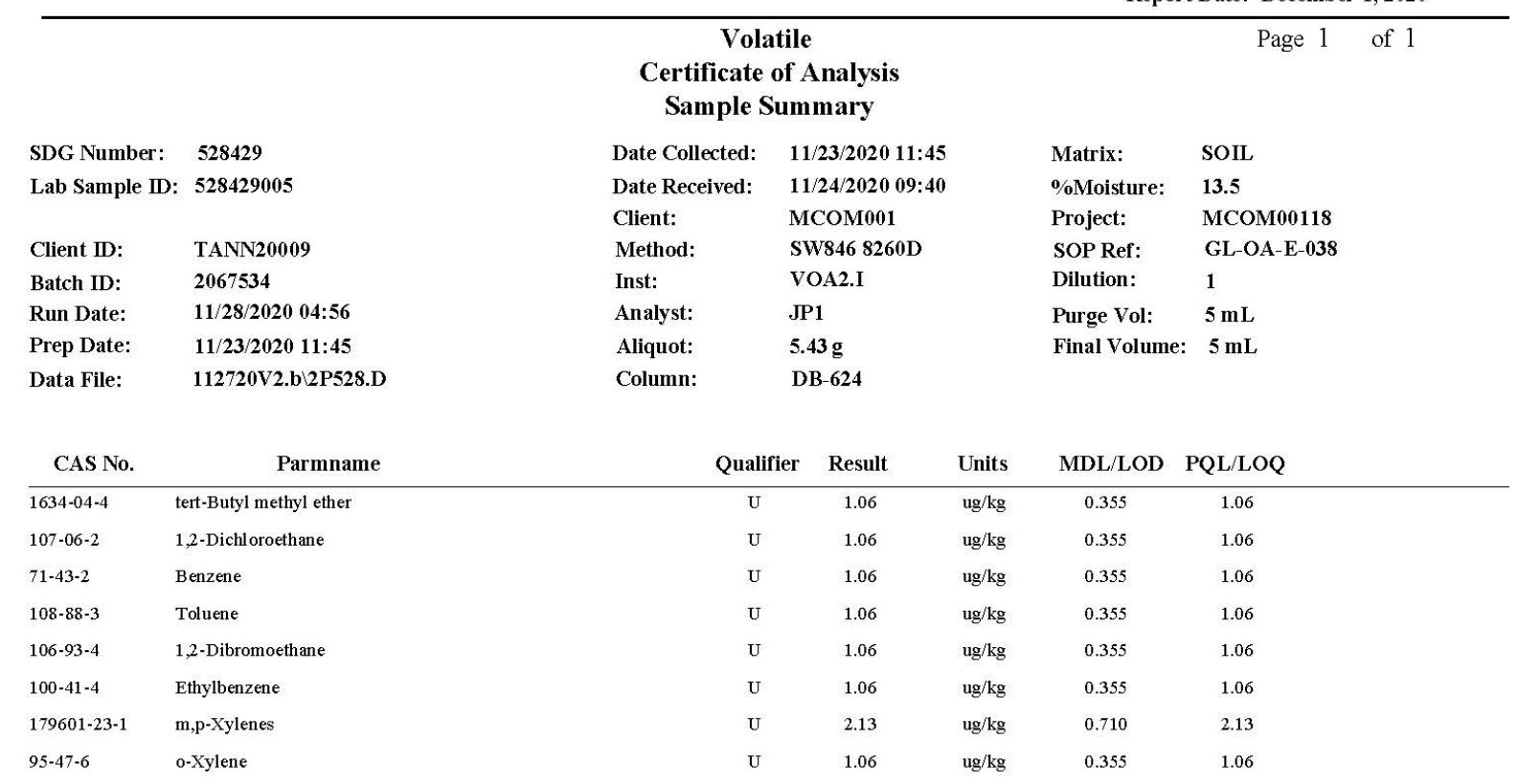

Page 22 of 151 SDG: 528429 


\begin{tabular}{|c|c|c|c|c|c|c|c|}
\hline \multicolumn{6}{|c|}{$\begin{array}{c}\text { Volatile } \\
\text { Certificate of Analysis } \\
\text { Sample Summary }\end{array}$} & \multicolumn{2}{|r|}{ Page 1 of 1} \\
\hline \multirow{3}{*}{$\begin{array}{l}\text { SDG Number: } \\
\text { Lab Sample ID: }\end{array}$} & \multirow{3}{*}{$\begin{array}{l}\mathbf{5 2 8 4 2 9} \\
\mathbf{5 2 8 4 2 9 0 0 6}\end{array}$} & Date Collected: & & Matrix: & SOIL \\
\hline & & Date Received: & \multicolumn{3}{|c|}{$11 / 24 / 202009: 40$} & \%Moisture: & 17.5 \\
\hline & & Client: & \multicolumn{3}{|c|}{ MCOM001 } & Project: & MCOM00118 \\
\hline Client ID: & TANN20010 & Method: & \multicolumn{3}{|c|}{ SW846 8260D } & SOP Ref: & GL-OA-E-038 \\
\hline Batch ID: & 2067534 & Inst: & \multicolumn{3}{|c|}{ VOA2.I } & Dilution: & 1 \\
\hline Run Date: & $11 / 28 / 202005: 22$ & Analyst: & \multicolumn{3}{|c|}{ JP1 } & \multirow{2}{*}{\multicolumn{2}{|c|}{ Purge Vol: $\quad 5 \mathrm{~mL}$}} \\
\hline Prep Date: & $11 / 23 / 202010: 00$ & Aliquot: & \multicolumn{3}{|c|}{$6.5 \mathrm{~g}$} & \multirow{2}{*}{\multicolumn{2}{|c|}{ Final Volume: $5 \mathrm{~mL}$}} \\
\hline Data File: & $112720 \mathrm{~V} 2 . \mathrm{b} \backslash 2 \mathrm{P} 529 . \mathrm{D}$ & Column: & \multicolumn{3}{|c|}{ DB-624 } & & \\
\hline CAS No. & Parmname & Qualif & & Result & Units & $\mathrm{MDL} / \mathrm{LOD}$ & PQL/LOQ \\
\hline $1634-04-4$ & tert-Butyl methyl ether & $\mathrm{U}$ & & 0.932 & $\mathrm{ug} / \mathrm{kg}$ & 0.310 & 0.932 \\
\hline $107-06-2$ & 1,2-Dichloroethane & U & & 0.932 & $\mathrm{ug} / \mathrm{kg}$ & 0.310 & 0.932 \\
\hline $71-43-2$ & Benzene & $\mathrm{U}$ & & 0.932 & $\mathrm{ug} / \mathrm{kg}$ & 0.310 & 0.932 \\
\hline 108-88-3 & Toluene & $\mathrm{U}$ & & 0.932 & $\mathrm{ug} / \mathrm{kg}$ & 0.310 & 0.932 \\
\hline $106-93-4$ & 1,2-Dibromoethane & $\mathrm{U}$ & & 0.932 & $\mathrm{ug} / \mathrm{kg}$ & 0.310 & 0.932 \\
\hline $100-41-4$ & Ethylbenzene & $\mathrm{U}$ & & 0.932 & $\mathrm{ug} / \mathrm{kg}$ & 0.310 & 0.932 \\
\hline 179601-23-1 & $\mathrm{m}, \mathrm{p}$-Xylenes & $\mathrm{U}$ & & 1.86 & $\mathrm{ug} / \mathrm{kg}$ & 0.622 & 1.86 \\
\hline $95-47-6$ & o-Xylene & $\mathrm{U}$ & & 0.932 & $\mathrm{ug} / \mathrm{kg}$ & 0.310 & 0.932 \\
\hline
\end{tabular}

Page 23 of 151 SDG: 528429 


\begin{tabular}{|c|c|c|c|c|c|c|c|}
\hline \multicolumn{6}{|c|}{$\begin{array}{c}\text { Volatile } \\
\text { Certificate of Analysis } \\
\text { Sample Summary }\end{array}$} & \multirow{3}{*}{ Matrix: } & Page 1 of 1 \\
\hline \multirow{3}{*}{$\begin{array}{l}\text { SDG Number: } \\
\text { Lab Sample ID: }\end{array}$} & \multirow{3}{*}{$\begin{array}{l}\mathbf{5 2 8 4 2 9} \\
\mathbf{5 2 8 4 2 9 0 0 7}\end{array}$} & Date Collected: & \multicolumn{3}{|c|}{$11 / 23 / 202011: 45$} & & WATER \\
\hline & & Date Received: & \multicolumn{3}{|c|}{$11 / 24 / 202009: 40$} & & \\
\hline & & Client: & \multicolumn{3}{|c|}{ MCOM001 } & Project: & MCOM00118 \\
\hline Client ID: & TRIP BLANK & Method: & \multicolumn{3}{|c|}{ SW846 8260D } & SOP Ref: & GL-OA-E-038 \\
\hline Batch ID: & 2067535 & Inst: & \multicolumn{3}{|c|}{ VOA3.I } & Dilution: & 1 \\
\hline Run Date: & $11 / 28 / 202004: 32$ & Analyst: & \multicolumn{3}{|c|}{ JP1 } & Purge Vol: & $5 \mathrm{~mL}$ \\
\hline Prep Date: & $11 / 28 / 202004: 32$ & & & & & & \\
\hline Data File: & $112720 \mathrm{~V} 3 \backslash 3 \mathrm{X} 525 . \mathrm{D}$ & Column: & \multicolumn{3}{|c|}{ DB-624 } & & \\
\hline CAS No. & Parmname & Quali & & Result & Units & $\mathrm{MDL} / \mathrm{LOD}$ & PQL/LOQ \\
\hline $1634-04-4$ & tert-Butyl methyl ether & $\mathrm{U}$ & & 1.00 & $\mathrm{ug} / \mathrm{L}$ & 0.333 & 1.00 \\
\hline $107-06-2$ & 1,2-Dichloroethane & U & & 1.00 & $\mathrm{ug} / \mathrm{L}$ & 0.333 & 1.00 \\
\hline $71-43-2$ & Benzene & U & & 1.00 & $\mathrm{ug} / \mathrm{L}$ & 0.333 & 1.00 \\
\hline 108-88-3 & Toluene & $\mathrm{U}$ & & 1.00 & $\mathrm{ug} / \mathrm{L}$ & 0.333 & 1.00 \\
\hline $106-93-4$ & 1,2-Dibromoethane & $\mathrm{U}$ & & 1.00 & $\mathrm{ug} / \mathrm{L}$ & 0.333 & 1.00 \\
\hline $100-41-4$ & Ethylbenzene & $\mathrm{U}$ & & 1.00 & $\mathrm{ug} / \mathrm{L}$ & 0.333 & 1.00 \\
\hline 179601-23-1 & $\mathrm{m}, \mathrm{p}$-Xylenes & U & & 2.00 & $\mathrm{ug} / \mathrm{L}$ & 0.667 & 2.00 \\
\hline $95-47-6$ & o-Xylene & U & & 1.00 & $\mathrm{ug} / \mathrm{L}$ & 0.333 & 1.00 \\
\hline
\end{tabular}

Page 24 of 151 SDG: 528429 


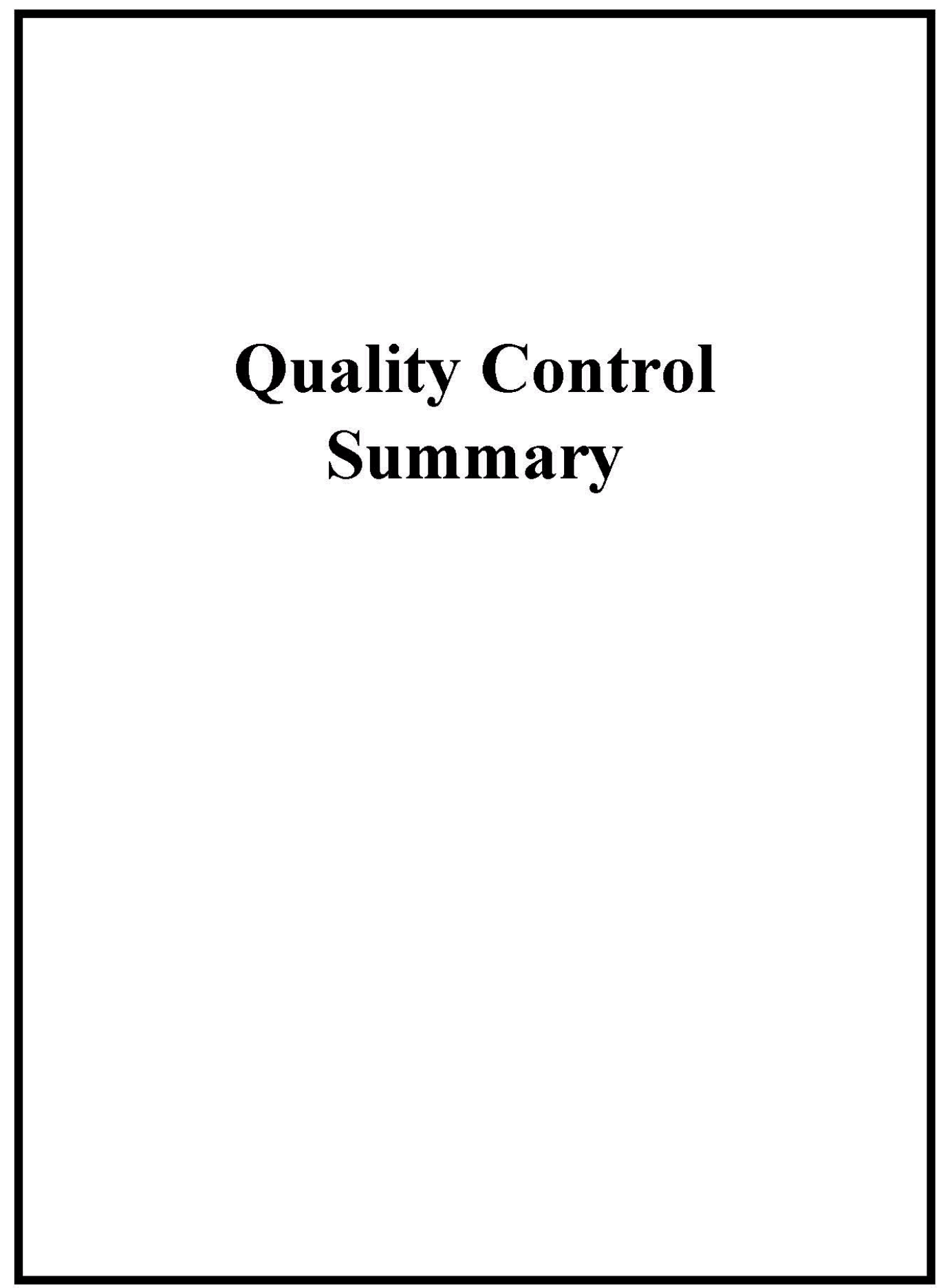

Page 25 of 151 SDG: 528429 


\section{Volatile \\ Surrogate Recovery Report}

Page 1

SDG Number: $\mathbf{5 2 8 4 2 9}$

Matrix Type: LIQUID

\begin{tabular}{llccc}
\hline Sample ID & Client ID & $\begin{array}{l}\text { DCED4 } \\
\text { \%REC }\end{array}$ & $\begin{array}{l}\text { TOL } \\
\text { \%REC }\end{array}$ & $\begin{array}{l}\text { BFB } \\
\text { \%REC }\end{array}$ \\
\hline 1204704454 & LCS for batch 2067535 & 102 & 101 & 99 \\
1204704452 & MB for batch 2067535 & 102 & 100 & 99 \\
528429007 & TRIP BLANK & 102 & 101 & 101 \\
1204704456 & B3XLX9PS & 99 & 99 & 96 \\
1204704457 & B3XLX9PSD & 100 & 100 & 98 \\
Surrogate & $\quad$ Parmname & & & Acceptance Limits \\
DCED4 & $=1$,2-Dichloroethane-d4 & & & $(71 \%-134 \%)$ \\
TOL & $=$ Toluene-d8 & & & $(74 \%-124 \%)$ \\
BFB & $=$ Bromofluorobenzene & & & $(70 \%-131 \%)$ \\
* Recovery outside Acceptance Limits & & & \\
\# Column to be used to flag recovery values & & &
\end{tabular}

Page 26 of 151 SDG: 528429 


\section{Surrogate Recovery Report}

Page 2 of 2

SDG Number: $\mathbf{5 2 8 4 2 9}$

Matrix Type: SOLID

\begin{tabular}{llccc}
\hline Sample ID & Client ID & $\begin{array}{c}\text { DCED4 } \\
\text { \%REC }\end{array}$ & $\begin{array}{l}\text { TOL } \\
\text { \%REC }\end{array}$ & $\begin{array}{l}\text { BFB } \\
\text { \%REC }\end{array}$ \\
\hline 1204704448 & LCS for batch 2067534 & 98 & 94 & 95 \\
1204704445 & MB for batch 2067534 & 93 & 93 & 93 \\
528429002 & TANN20006 & 89 & 94 & 93 \\
528429003 & TANN20007 & 95 & 92 & 93 \\
528429004 & TANN20008 & 94 & 91 & 93 \\
528429005 & TANN20009 & 90 & 94 & 94 \\
528429006 & TANN20010 & 89 & 94 & 97 \\
1204704449 & LCS for batch 2067534 & 100 & 99 & 96 \\
1204704446 & MB for batch 2067534 & 96 & 98 & 91 \\
1204704450 & IS NO.1PS & 98 & 100 & 97 \\
1204704451 & IS NO.1PSD & 99 & 98 & 95 \\
Surrogate & $\quad$ Parmname & & & Acceptance Limits \\
DCED4 & $=$ 1,2-Dichloroethane-d4 & & & $(81 \%-124 \%)$ \\
TOL & $=$ Toluene-d8 & & & $(81 \%-120 \%)$ \\
BFB & = Bromofluorobenzene & & & $(70 \%-130 \%)$ \\
$*$ Recovery outside Acceptance Limits & & & \\
\# Column to be used to flag recovery values & & & \\
D Sample Diluted & & & &
\end{tabular}




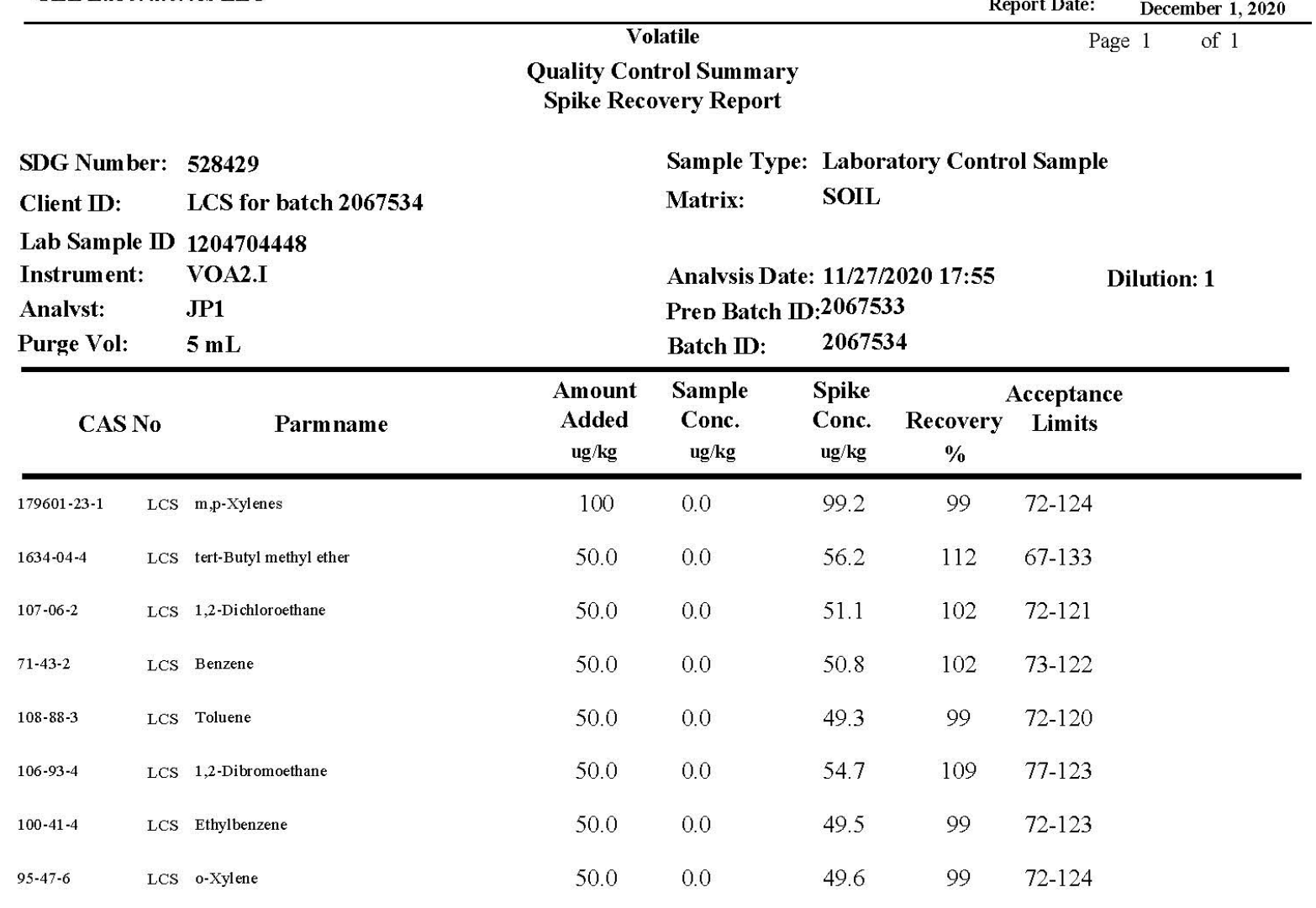




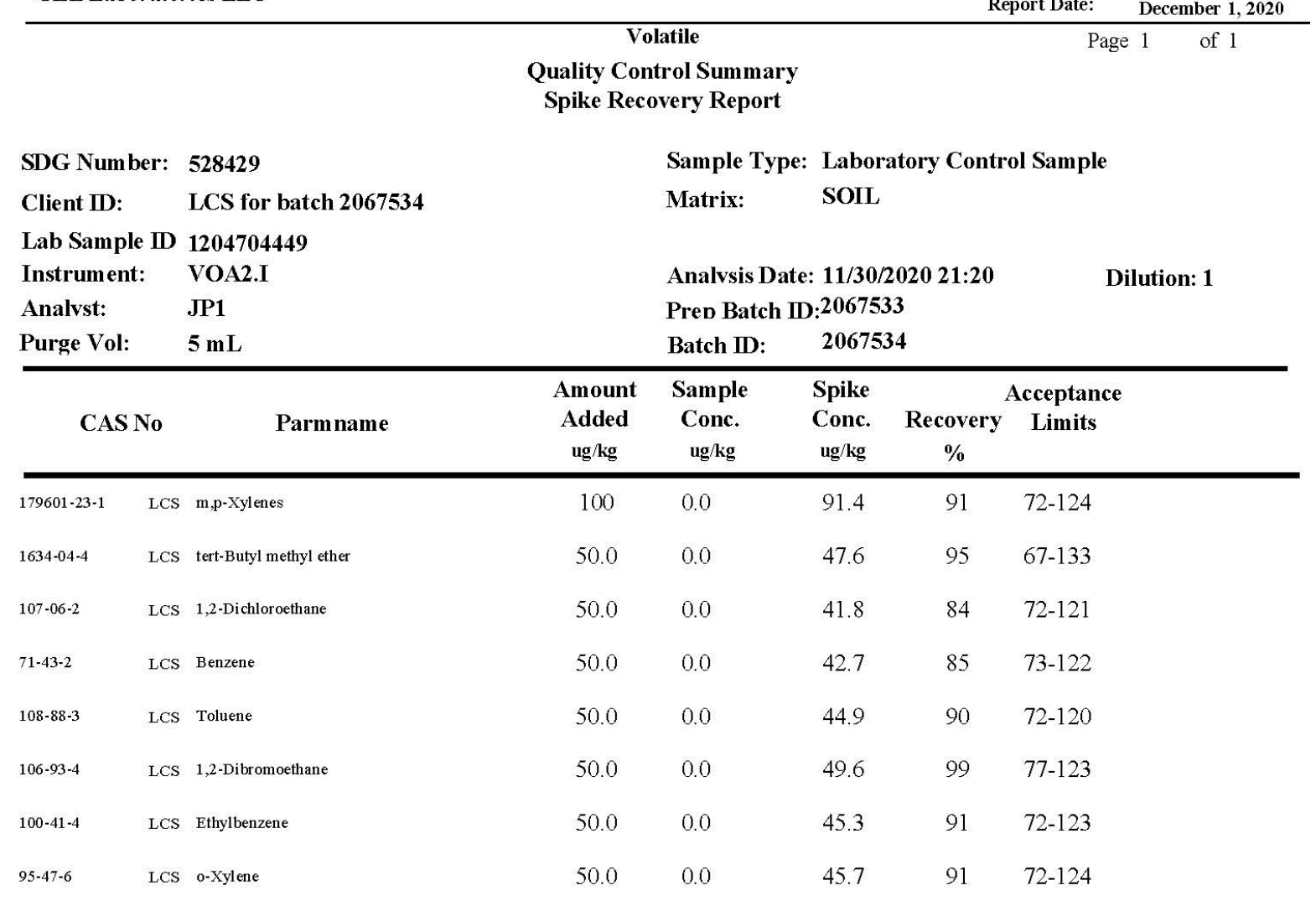




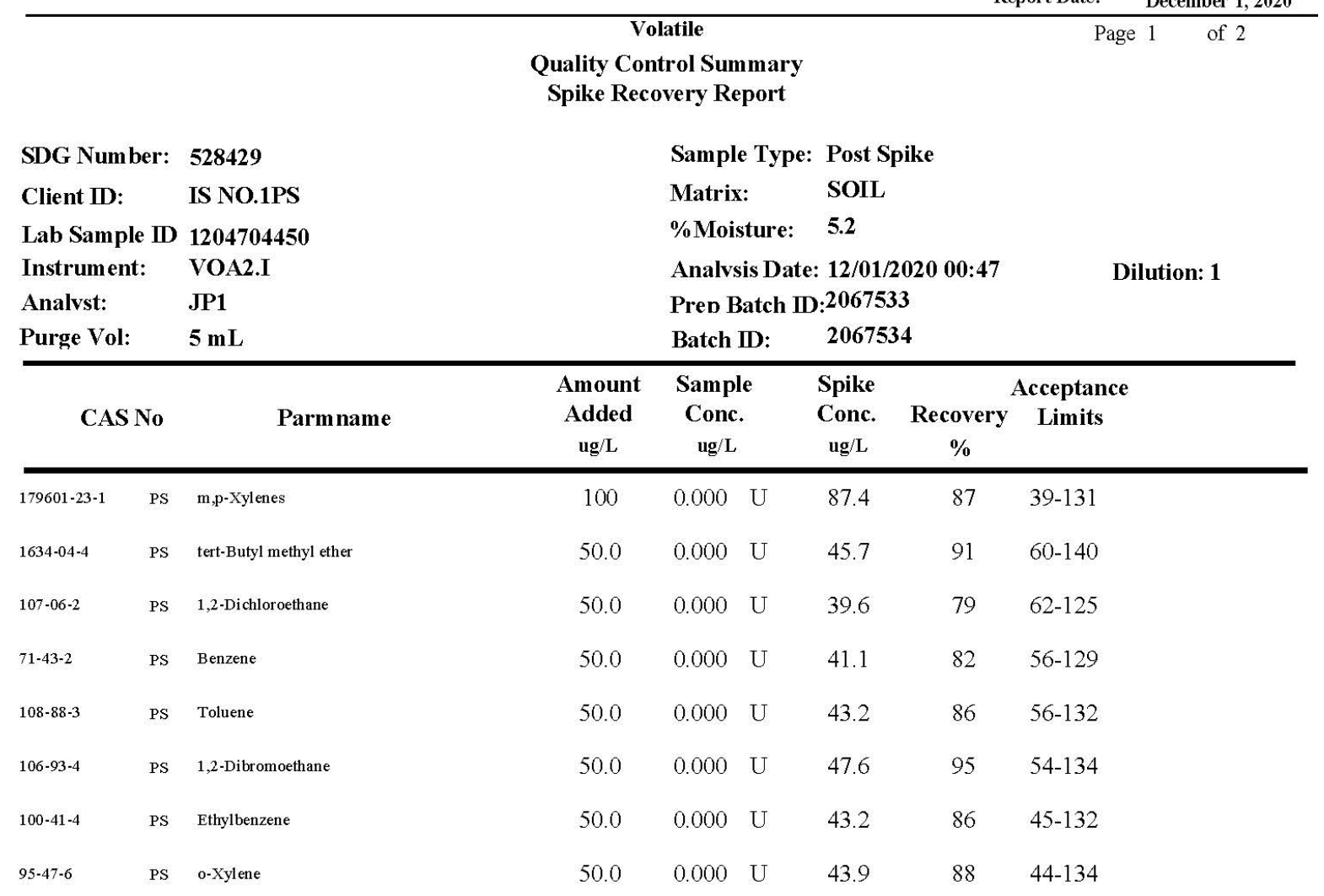




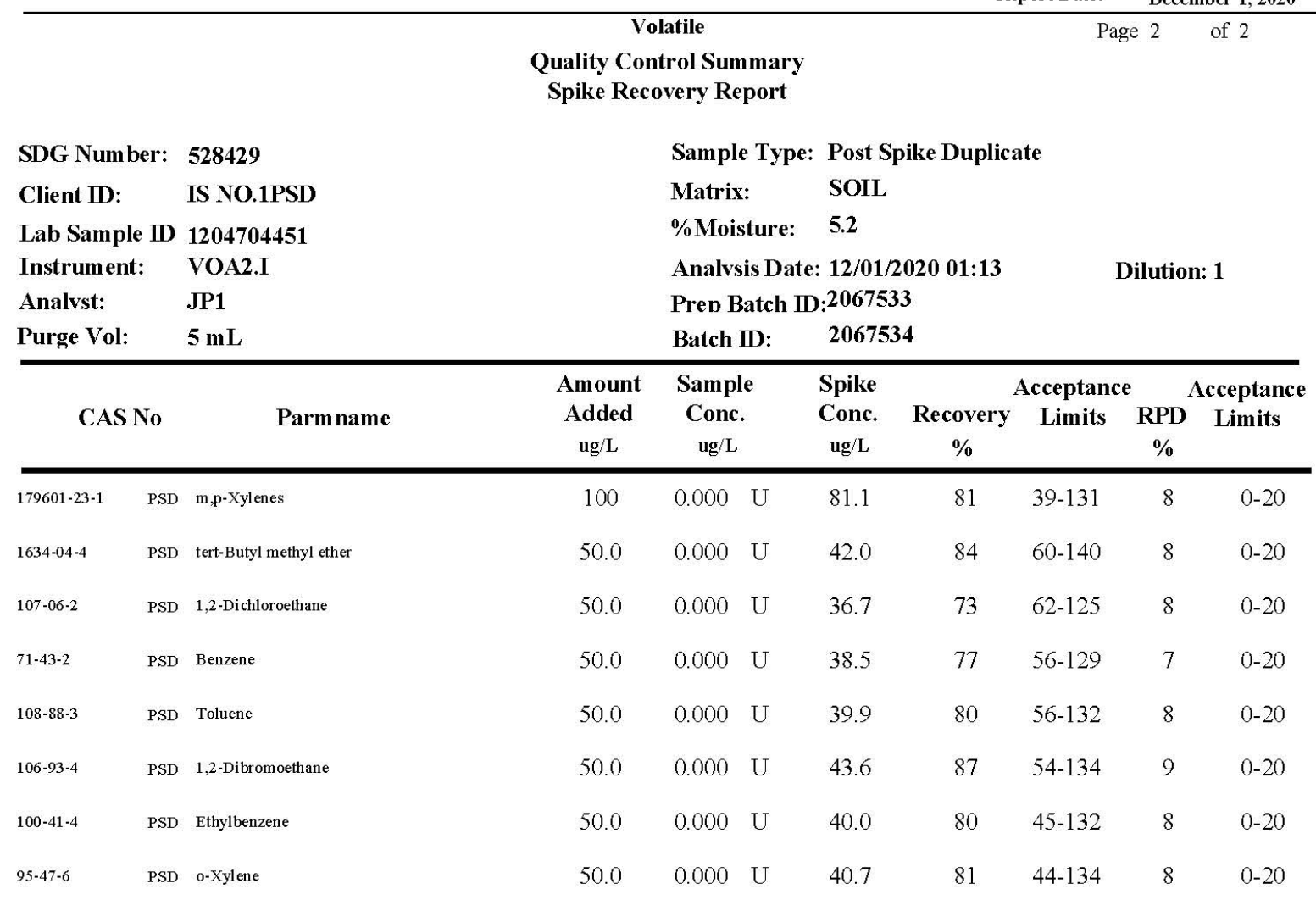




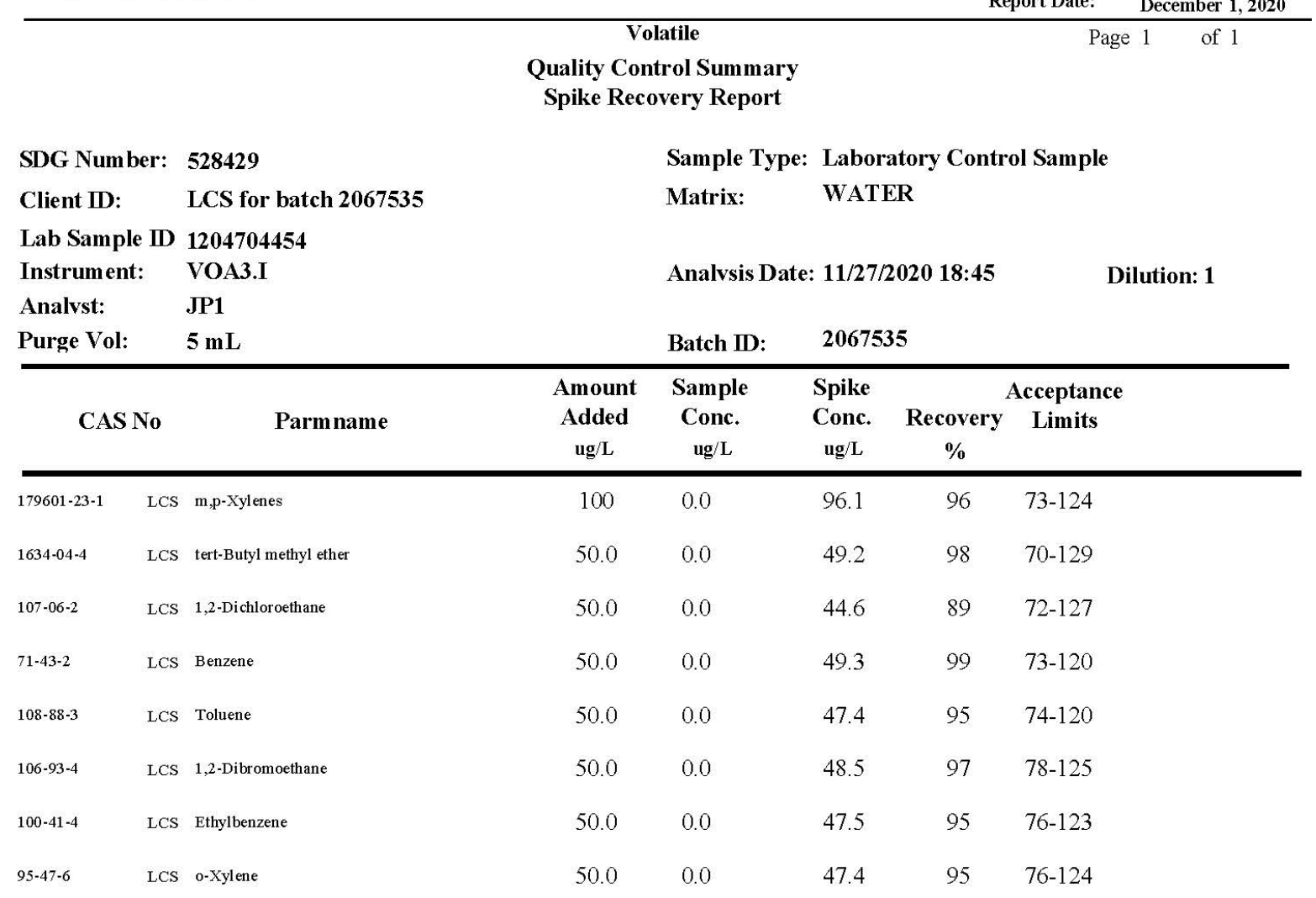




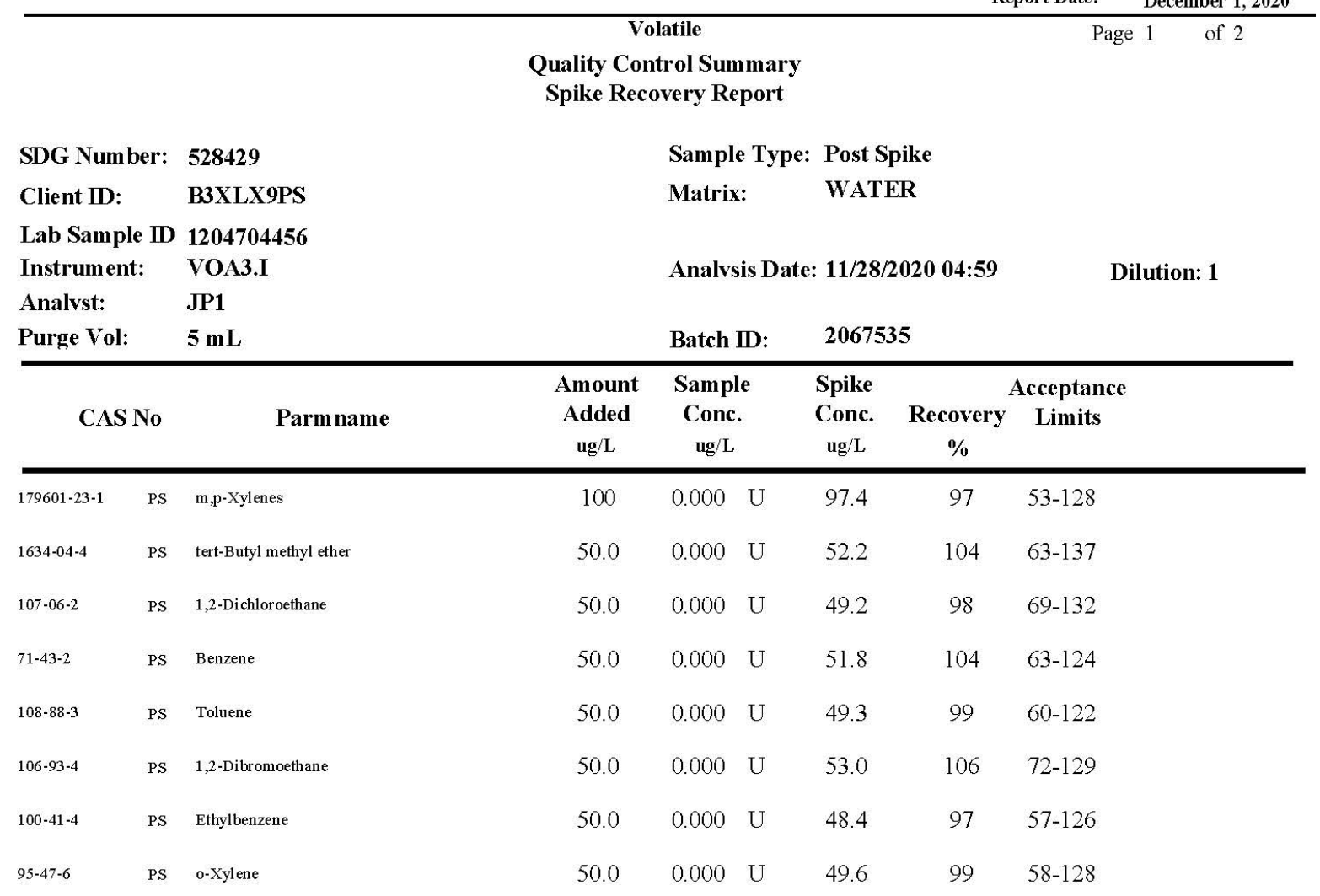




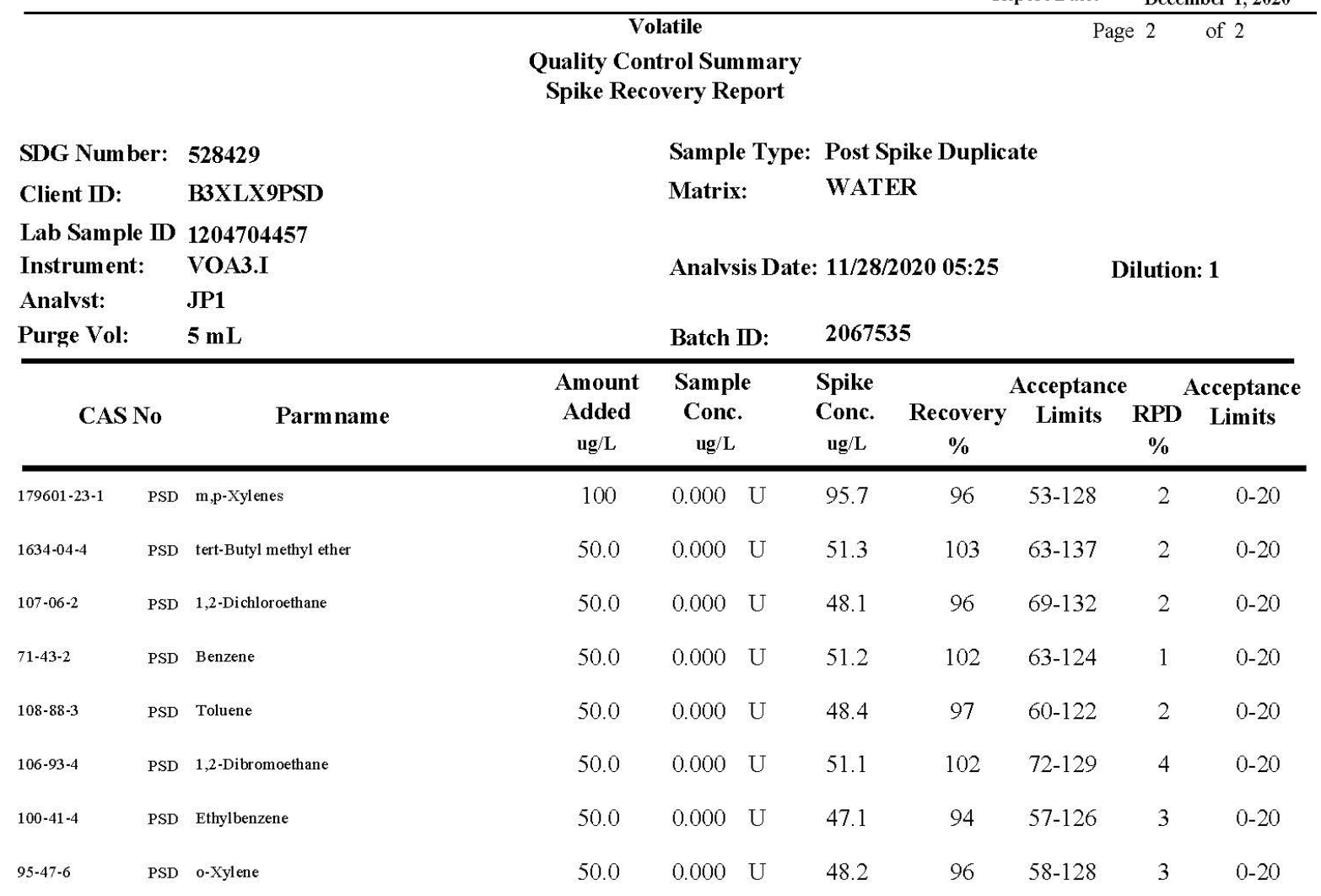


Method Blank Summary

$\begin{array}{ll}\text { SDG Number: } & 528429 \\ \text { Client ID: } & \text { MB for batch } 2067534 \\ \text { Lab Sample ID: } & 1204704445 \\ \text { Column: } & \text { DB-624 }\end{array}$

This method blank applies to the following samples and quality control samples:

Client Sample ID
$01 \quad$ LCS for batch 2067534
02 TANN20006
03 TANN20007
04 TANN20008
05 TANN20009
06 TANN20010

$\begin{array}{ll}\text { Client: } & \text { MCOM001 } \\ \text { Instrument ID: } & \text { VOA2.I } \\ \text { Prep Date: } & \text { 11/27/2020 16:30 }\end{array}$

Lab Sample ID
$\mathbf{1 2 0 4 7 0 4 4 4}$
$\mathbf{5 2 8 4 2 9 0 0 2}$
$\mathbf{5 2 8 4 2 9 0 0 3}$
$\mathbf{5 2 8 4 2 9 0 0 4}$
$\mathbf{5 2 8 4 2 9 0 0 5}$
$\mathbf{5 2 8 4 2 9 0 0 6}$

File ID
$112720 \mathrm{~V} 2 . \mathrm{b} \backslash 2 \mathrm{P} 503 \mathrm{~L} 34 . \mathrm{D}$
$112720 \mathrm{~V} 2 . \mathrm{b} \backslash 2 \mathrm{P} 525 . \mathrm{D}$
$112720 \mathrm{~V} 2 . \mathrm{b} \backslash 2 \mathrm{P} 526 . \mathrm{D}$
$112720 \mathrm{~V} 2 . \mathrm{b} \backslash 2 \mathrm{P} 527 . \mathrm{D}$
$112720 \mathrm{~V} 2 . \mathrm{b} \backslash 2 \mathrm{P} 528 . \mathrm{D}$
$112720 \mathrm{~V} 2 . \mathrm{b} \backslash 2 \mathrm{P} 529 . \mathrm{D}$

Matrix: SOIL Data File: $112720 \mathrm{~V} 2 . \mathrm{b} \backslash 2 \mathrm{P507B34.D}$ Analyzed: $\quad 11 / 27 / 2019: 38$

$\begin{array}{cc}\text { Date Analyzed } & \text { Time Analyzed } \\ 11 / 27 / 20 & 1755 \\ 11 / 28 / 20 & 0339 \\ 11 / 28 / 20 & 0404 \\ 11 / 28 / 20 & 0431 \\ 11 / 28 / 20 & 0456 \\ 11 / 28 / 20 & 0522\end{array}$

Page 35 of 151 SDG: 528429 
Method Blank Summary

$\begin{array}{ll}\text { SDG Number: } & \mathbf{5 2 8 4 2 9} \\ \text { Client ID: } & \text { MB for batch } 2067534 \\ \text { Lab Sample ID: } & 1204704446 \\ \text { Column: } & \text { DB-624 }\end{array}$

This method blank applies to the following samples and quality control samples:

Client Sample ID

08 LCS for batch 2067534

09 IS NO.1PS

10 IS NO.1PSD
Lab Sample ID

1204704449

1204704450

1204704451
File ID

$113020 \mathrm{~V} 2 . \mathrm{b} \backslash 2 \mathrm{Q} 107 \mathrm{~L} 34 . \mathrm{D}$

$113020 \mathrm{~V} 2 . \mathrm{b} \backslash 2 \mathrm{Q} 115 . \mathrm{D}$

$113020 \mathrm{~V} 2 . \mathrm{b} \backslash 2 \mathrm{Q} 116 . \mathrm{D}$
Page 1 of 1

Matrix: SOIL

Data File: $113020 V 2 . b \cup 2 Q 110 B 34 . D$

Analyzed: $\quad 11 / 30 / 2022: 38$
Date Analyzed Time Analyzed

$11 / 30 / 2$

2120

$12 / 01 / 20$

0047

$12 / 01 / 20$

0113 
Method Blank Summary

$\begin{array}{ll}\text { SDG Number: } & \mathbf{5 2 8 4 2 9} \\ \text { Client ID: } & \text { MB for batch } 2067535 \\ \text { Lab Sample ID: } & \mathbf{1 2 0 4 7 0 4 4 5 2} \\ \text { Column: } & \text { DB-624 }\end{array}$

This method blank applies to the following samples and quality control samples:

Client Sample ID
$01 \quad$ LCS for batch 2067535
02 TRIP BLANK
03 B3XLX9PS
04 B3XLX9PSD

$\begin{array}{ll}\text { Client: } & \text { MCOM001 } \\ \text { Instrument ID: } & \text { VOA3.I } \\ \text { Prep Date: } & \mathbf{1 1 / 2 7 / 2 0 2 0 ~ 2 0 : 0 5}\end{array}$

$\begin{array}{rc}\text { Lab Sample ID } & \text { File ID } \\ 1204704454 & 112720 \text { V3 } \backslash 3 \times 503 \text { L35.D } \\ 528429007 & 112720 \text { V3 } \backslash 3 \times 525 . D \\ 1204704456 & 112720 \text { V3 } \backslash 3 \times 526 . D \\ 1204704457 & 112720 \text { V3 } \backslash 3 \times 527 . D\end{array}$

Matrix: WATER

Data File: $112720 \mathrm{V3} \backslash 3 \times 506 \mathrm{~B} 35 . \mathrm{D}$

Analyzed: $\quad 11 / 27 / 2020: 05$

$\begin{array}{cc}\text { Date Analyzed } & \text { Time Analyzed } \\ 11 / 27 / 20 & 1845 \\ 11 / 28 / 20 & 0432 \\ 11 / 28 / 20 & 0459 \\ 11 / 28 / 20 & 0525\end{array}$

Page 37 of 151 SDG: 528429 
Instrument Performance Check

BROMOFLUOROBENZENE

Lab Name GEL Laboratories LLC

Instrument ID: VOA2.I

Column Description: Description: DB-624
Client SDG: 528429

Injection Date/Time: 13-OCT-20 20:39

\begin{tabular}{|c|c|c|}
\hline $\mathbf{m} / \mathbf{e}$ & Ion Abundance Criteria & \% Relative Abundance \\
\hline 50 & $15.0-40.0 \%$ of mass 95 & 23.2 \\
\hline 75 & $30.0-60.0 \%$ of mass 95 & 48.6 \\
\hline 95 & $50-200 \%$ of mass 174 & 124 \\
\hline 96 & $5.0-9.0 \%$ of mass 95 & 7.1 \\
\hline 173 & Less than $2.0 \%$ of mass 174 & 0.6 \\
\hline 174 & $50-200 \%$ of mass 95 & 80.6 \\
\hline 175 & $5.0-9.0 \%$ of mass 174 & 7.3 \\
\hline 176 & $95.0-105.0 \%$ of mass 174 & 97.6 \\
\hline 177 & $5.0-10.0 \%$ of mass 176 & 6.6 \\
\hline
\end{tabular}

THIS CHECK APPLIES TO THE FOLLOWING SAMPLES, MS, MSD, LCS, LCSD,BLANKS AND STANDARDS

\begin{tabular}{|c|c|c|c|}
\hline $\begin{array}{c}\text { Client } \\
\text { Sample ID }\end{array}$ & $\begin{array}{c}\text { Lab } \\
\text { Sample ID }\end{array}$ & $\begin{array}{c}\text { Lab } \\
\text { File ID }\end{array}$ & $\begin{array}{c}\text { Time } \\
\text { Analyzed }\end{array}$ \\
\hline ICALMIX[A] & W2VM201013-02 & 101320V2.b\2J203.D & 13-OCT-20 21:31 \\
\hline ICALMIX[A] & W2VM201013-03 & 101320V2.b\2J204.D & 13-OCT-20 21:57 \\
\hline ICALMIX[A] & W2VM201013-04 & 101320V2.b\2J205.D & 13-OCT-20 22:23 \\
\hline ICALMIX[A] & W2VM201013-05 & 101320V2.b\2J206.D & 13-OCT-20 22:49 \\
\hline ICALMIX[A] & W2VM201013-06 & 101320V2.b\2J207.D & 13-OCT-20 23:15 \\
\hline ICALMIX[A] & W2VM201013-07 & 101320V2.b\2J208.D & 13-OCT-20 23:40 \\
\hline ICALMIX[A] & W2VM201013-08 & 101320V2.b\2J209.D & 14-OCT-20 00:06 \\
\hline ICALMIX[A] & W2VM201013-09 & 101320V2.b\2J210.D & 14-OCT-20 00:32 \\
\hline ICALMIX[A] & W2VM201013-10 & 101320V2.b\2J211.D & 14-OCT-20 00:58 \\
\hline
\end{tabular}

Page 38 of 151 SDG: 528429 
Instrument Performance Check

BROMOFLUOROBENZENE

Lab Name GEL Laboratories LLC

Instrument ID: VOA2.I

Column Description: Description: DB-624
Client SDG: 528429

Injection Date/Time: 14-OCT-20 17:44

\begin{tabular}{|c|c|c|}
\hline $\mathbf{m} / \mathbf{e}$ & Ion Abundance Criteria & \% Relative Abundance \\
\hline 50 & $15.0-40.0 \%$ of mass 95 & 22.2 \\
\hline 75 & $30.0-60.0 \%$ of mass 95 & 49 \\
\hline 95 & $50-200 \%$ of mass 174 & 123 \\
\hline 96 & $5.0-9.0 \%$ of mass 95 & 6.9 \\
\hline 173 & Less than $2.0 \%$ of mass 174 & 0.6 \\
\hline 174 & $50-200 \%$ of mass 95 & 81.3 \\
\hline 175 & $5.0-9.0 \%$ of mass 174 & 7.2 \\
\hline 176 & $95.0-105.0 \%$ of mass 174 & 97 \\
\hline 177 & $5.0-10.0 \%$ of mass 176 & 6.8 \\
\hline
\end{tabular}

THIS CHECK APPLIES TO THE FOLLOWING SAMPLES, MS, MSD, LCS, LCSD,BLANKS AND STANDARDS

\begin{tabular}{|c|c|c|c|}
\hline $\begin{array}{c}\text { Client } \\
\text { Sample ID }\end{array}$ & $\begin{array}{c}\text { Lab } \\
\text { Sample ID }\end{array}$ & $\begin{array}{c}\text { Lab } \\
\text { File ID }\end{array}$ & $\begin{array}{c}\text { Time } \\
\text { Analyzed }\end{array}$ \\
\hline ICVMIX[A]01 & W2VM201014-01 & 101420V2.b\2J302.D & 14-OCT-20 18:09 \\
\hline CCVMIX[A] 01 & W2VM201127-01 & 112720V2.b\2P502.D & 27-NOV-20 17:29 \\
\hline BLK01LCS & 1204704448 & 112720V2.b\2P503L34.D & 27-NOV-20 17:55 \\
\hline BLK01 & 1204704445 & 112720V2.b\2P507B34.D & 27-NOV-20 19:38 \\
\hline TANN20006 & 528429002 & 112720V2.b\2P525.D & 28-NOV-20 03:39 \\
\hline TANN20007 & 528429003 & 112720V2.b\2P526.D & 28-NOV-20 04:04 \\
\hline TANN20008 & 528429004 & 112720V2.b\2P527.D & 28-NOV-20 04:31 \\
\hline TANN20009 & 528429005 & $112720 \mathrm{~V} 2 . \mathrm{b} \backslash 2 \mathrm{P} 528 . \mathrm{D}$ & 28-NOV-20 04:56 \\
\hline TANN20010 & 528429006 & 112720V2.b\2P529.D & 28-NOV-20 05:22 \\
\hline CCVMIX[A]02 & W2VM201130-05 & 113020V2.b\2Q106.D & 30-NOV-20 20:54 \\
\hline BLK03LCS & 1204704449 & 113020V2.b\2Q107L34.D & 30-NOV-20 21:20 \\
\hline BLK03 & 1204704446 & 113020V2.b\2Q110B34.D & 30-NOV-20 22:38 \\
\hline IS NO.1MS & 1204704450 & 113020V2.b\2Q115.D & 01-DEC-20 00:47 \\
\hline IS NO.1MSD & 1204704451 & 113020V2.b\2Q116.D & 01-DEC-20 01:13 \\
\hline
\end{tabular}

Page 39 of $151 \quad$ SDG: 528429 


\section{Instrument Performance Check}

BROMOFLUOROBENZENE

Lab Name GEL Laboratories LLC

Instrument ID: VOA3.I

Column Description: $\quad$ DB-624
Client SDG: 528429

Injection Date/Time: 25-NOV-20 16:55

\begin{tabular}{|c|c|c|}
\hline $\mathbf{m} / \mathbf{e}$ & Ion Abundance Criteria & \% Relative Abundance \\
\hline 50 & $15.0-40.0 \%$ of mass 95 & 21.6 \\
\hline 75 & $30.0-60.0 \%$ of mass 95 & 51.6 \\
\hline 95 & $50-200 \%$ of mass 174 & 112.9 \\
\hline 96 & $5.0-9.0 \%$ of mass 95 & 6.8 \\
\hline 173 & Less than $2.0 \%$ of mass 174 & 0.7 \\
\hline 174 & $50-200 \%$ of mass 95 & 88.5 \\
\hline 175 & $5.0-9.0 \%$ of mass 174 & 6.4 \\
\hline 176 & $95.0-105.0 \%$ of mass 174 & 99.7 \\
\hline 177 & $5.0-10.0 \%$ of mass 176 & 6.5 \\
\hline
\end{tabular}

THIS CHECK APPLIES TO THE FOLLOWING SAMPLES, MS, MSD, LCS, LCSD,BLANKS AND STANDARDS

\begin{tabular}{|c|c|c|c|}
\hline \begin{tabular}{c|c|} 
Client \\
Sample ID
\end{tabular} & $\begin{array}{c}\text { Lab } \\
\text { Sample ID }\end{array}$ & $\begin{array}{c}\text { Lab } \\
\text { File ID }\end{array}$ & $\begin{array}{c}\text { Time } \\
\text { Analyzed }\end{array}$ \\
\hline ICALMIX[A] & W3VM201125-01 & $112520 \mathrm{~V} 3 \backslash 3 \mathrm{X} 302 . \mathrm{D}$ & $25-N O V-20 \quad 17: 22$ \\
\hline ICALMIX[A] & W3VM201125-02 & 112520V3\3X303.D & 25-NOV-20 17:48 \\
\hline ICALMIX[A] & W3VM201125-03 & 112520V3 33X304.D & 25-NOV-20 18:15 \\
\hline ICALMIX[A] & W3VM201125-04 & 112520V3\3X305.D & 25-NOV-20 18:42 \\
\hline ICALMIX[A] & W3VM201125-05 & $112520 \mathrm{~V} 3 \backslash 3 \times 306 . \mathrm{D}$ & 25-NOV-20 19:09 \\
\hline ICALMIX[A] & W3VM201125-06 & 112520V3\3X307.D & 25-NOV-20 19:36 \\
\hline ICALMIX[A] & W3VM201125-07 & 112520V3\3X308.D & 25-NOV-20 20:03 \\
\hline ICALMIX[A] & W3VM201125-08 & 112520V3\3X309.D & $25-N O V-20 \quad 20: 30$ \\
\hline ICALMIX[A] & W3VM201125-09 & $112520 \mathrm{~V} 3 \backslash 3 \mathrm{X} 310 . \mathrm{D}$ & 25-NOV-20 20:56 \\
\hline ICVMIX[A]01 & W3VM201125-10 & $112520 \mathrm{~V} 3 \backslash 3 \mathrm{X} 312 . \mathrm{D}$ & 25-NOV-20 21:50 \\
\hline CCVMIX[A]01 & W3VM201127-02 & $112720 \mathrm{~V} 3 \backslash 3 \mathrm{X} 503 . \mathrm{D}$ & 27-NOV-20 18:45 \\
\hline BLK02LCS & 1204704454 & $112720 \mathrm{~V} 3 \backslash 3 \mathrm{X} 503 \mathrm{~L} 35 . \mathrm{D}$ & 27-NOV-20 18:45 \\
\hline BLK02 & 1204704452 & $112720 \mathrm{~V} 3 \backslash 3 \mathrm{X} 506 \mathrm{~B} 35 . \mathrm{D}$ & 27-NOV-20 20:05 \\
\hline TRIP BLANK & 528429007 & $112720 \mathrm{~V} 3 \backslash 3 \mathrm{X} 525 . \mathrm{D}$ & 28-NOV-20 04:32 \\
\hline B3XLX9MS & 1204704456 & $112720 \mathrm{~V} 3 \backslash 3 \times 526 . \mathrm{D}$ & 28-NOV-20 04:59 \\
\hline B3XLX9MSD & 1204704457 & 112720V3\3X527.D & 28-NOV-20 $05: 25$ \\
\hline
\end{tabular}

Page 40 of 151 SDG: 528429 


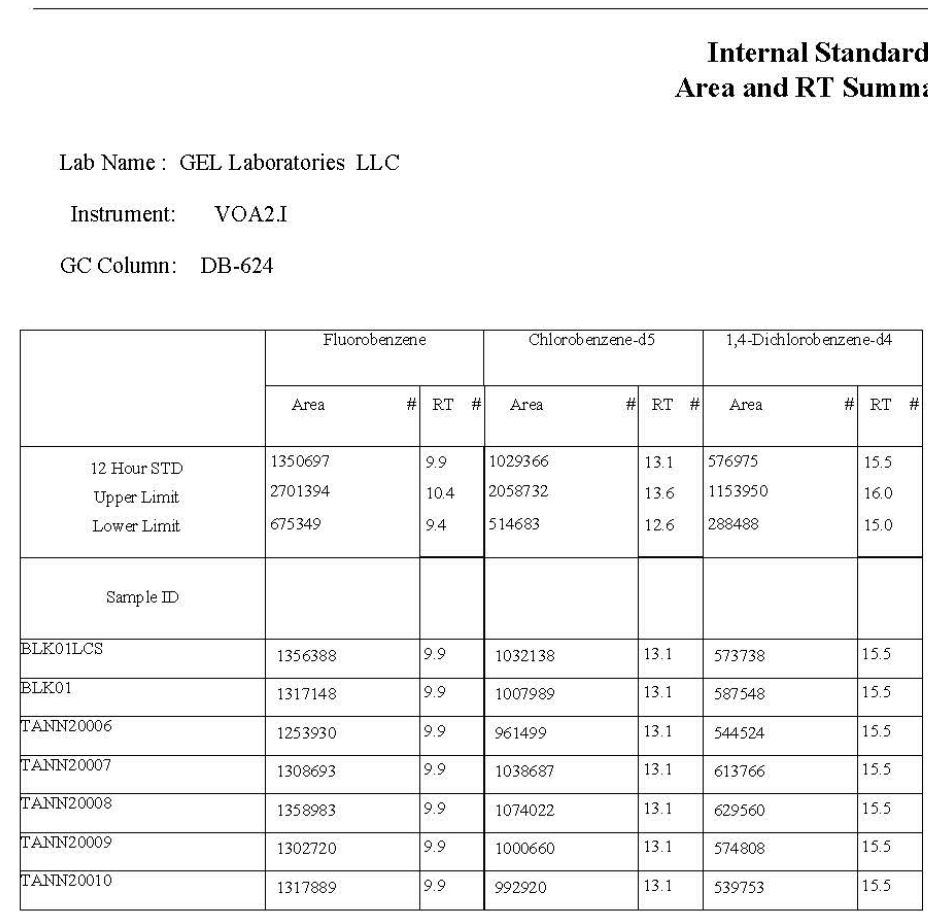

Page 1 of 1

\section{Area and RT Summary}

Client SDG: 528429

STD Analysis Time: $\quad$ 27-NOV-20 17:29

Data File: $\quad 112720$ V2.b\2P502.D

Area Upper Limit $=+100 \%$ of internal standard area

Area Lower Limit $=-50 \%$ of internal standard area

RT Upper Limit $=+0.50$ minutes of internal standard RT

RT Lower Limit $=-0.50$ minutes of internal standard RT

\# Column used to flag values outside QC limits with an asterisk

* Value outside of QC Limits

Page 41 of 151 SDG: 528429 


\begin{tabular}{|c|c|c|c|c|c|c|c|c|c|}
\hline & & & & & & \multicolumn{4}{|c|}{$\begin{array}{l}\text { Internal Standard } \\
\text { Area and RT Summa }\end{array}$} \\
\hline \multicolumn{10}{|c|}{ Lab Name: GEL Laboratories LLC } \\
\hline Instrument: & VOA2.I & & & & & & & & \\
\hline \multicolumn{10}{|c|}{ GC Column: DB-624 } \\
\hline & \multicolumn{3}{|c|}{ Fluorobenzene } & \multicolumn{3}{|c|}{ Chlorobenzene-d5 } & \multicolumn{3}{|c|}{ 1,4-Dichlorobenzene-d4 } \\
\hline & Area & $\#$ & RT \# & Area & \# & RT \# & Area & \# & RT \# \\
\hline 12 Hour STD & 1598820 & & 9.9 & 1153905 & & 13.1 & 625299 & & 15.5 \\
\hline Upper Limit & 3197640 & & 10.4 & 2307810 & & 13.6 & 1250598 & & 16.0 \\
\hline Lower Limit & 799410 & & 9.4 & 576953 & & 12.6 & 312650 & & 15.0 \\
\hline \multicolumn{10}{|l|}{ Sample ID } \\
\hline BLK03LCS & 1591735 & & 9.9 & 1143334 & & 13.1 & 622265 & & 15.5 \\
\hline BLK03 & 1562368 & & 9.9 & 1131832 & & 13.1 & 654376 & & 15.5 \\
\hline IS NO.1MS & 1663638 & & 9.9 & 1186414 & & 13.1 & 636257 & & 15.5 \\
\hline IS NO.1MSD & 1685277 & & 9.9 & 1220984 & & 13.1 & 661665 & & 15.5 \\
\hline
\end{tabular}

Page 1 of 1

\title{
Area and RT Summary
}

Client SDG: 528429

STD Analysis Time: $\quad 30$-NOV-20 20:54

Data File: $\quad 113020 \mathrm{~V} 2 . \mathrm{b} \backslash 2 \mathrm{Q} 106 . \mathrm{D}$

\begin{abstract}
Area Upper Limit $=+100 \%$ of internal standard area
Area Lower Limit $=-50 \%$ of internal standard area

RT Upper Limit $=+0.50$ minutes of internal standard RT

RT Lower Limit $=-0.50$ minutes of internal standard RT

\# Column used to flag values outside QC limits with an asterisk

* Value outside of QC Limits
\end{abstract}

Page 42 of 151 SDG: 528429 


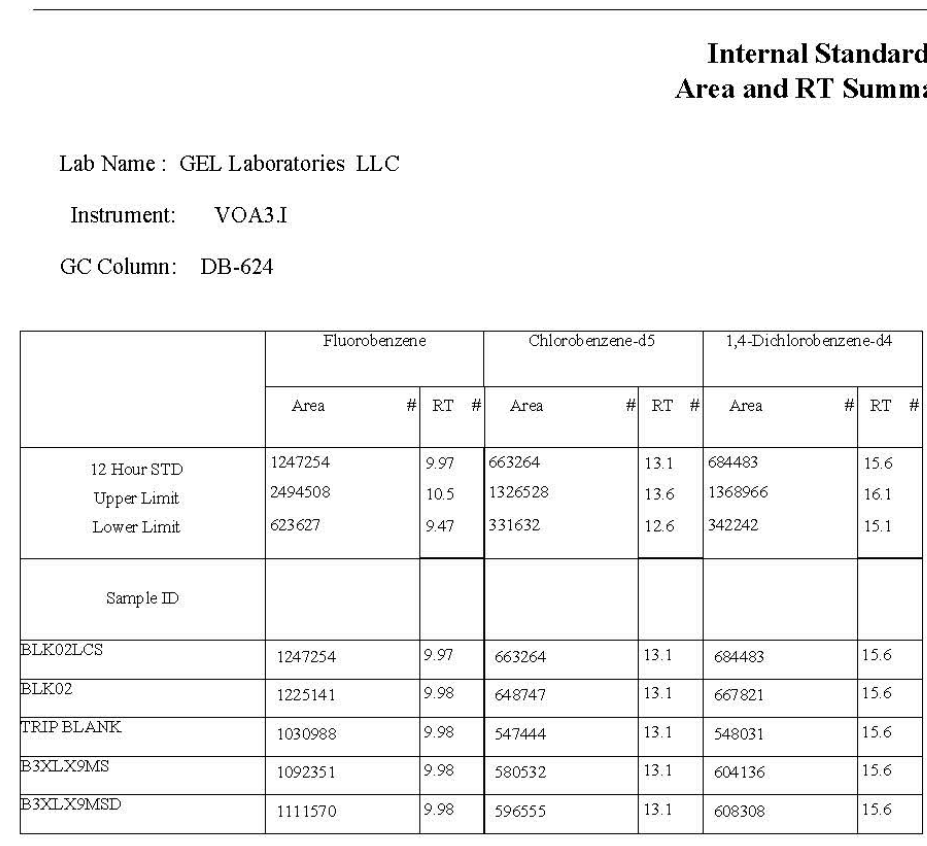

Page 1 of 1

\section{Area and RT Summary}

Client SDG: 528429

STD Analysis Time: $\quad$ 27-NOV-20 18:45

Data File: $\quad 112720 \mathrm{~V} 3 \backslash 3 \mathrm{X} 503 . \mathrm{D}$

Area Upper Limit $=+100 \%$ of internal standard area

Area Lower Limit $=-50 \%$ of internal standard area

RT Upper Limit $=+0.50$ minutes of internal standard RT

RT Lower Limit $=-0.50$ minutes of internal standard RT

\# Column used to flag values outside QC limits with an asterisk

* Value outside of QC Limits

Page 43 of 151 SDG: 528429 


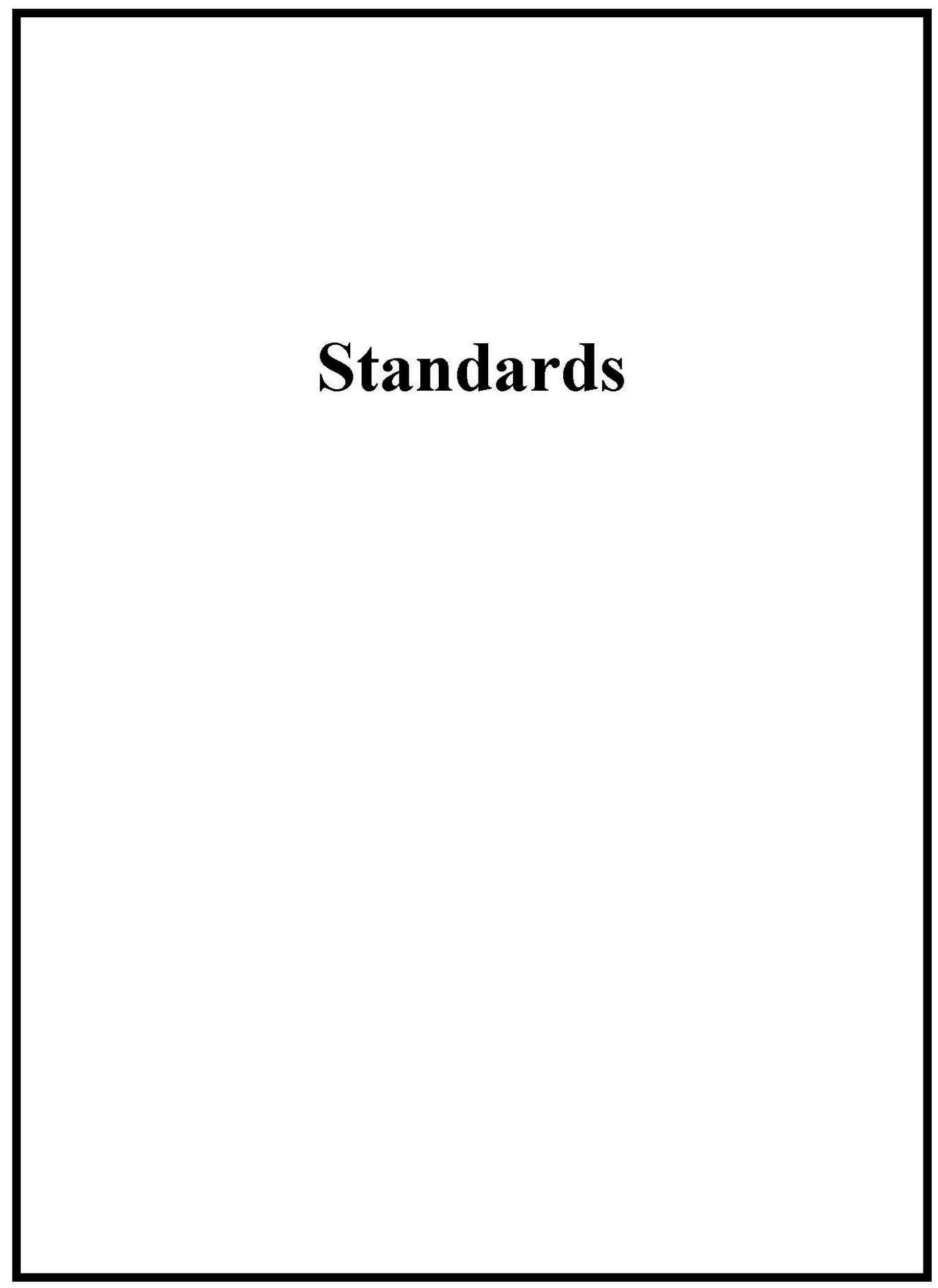

Page 44 of 151 SDG: 528429 


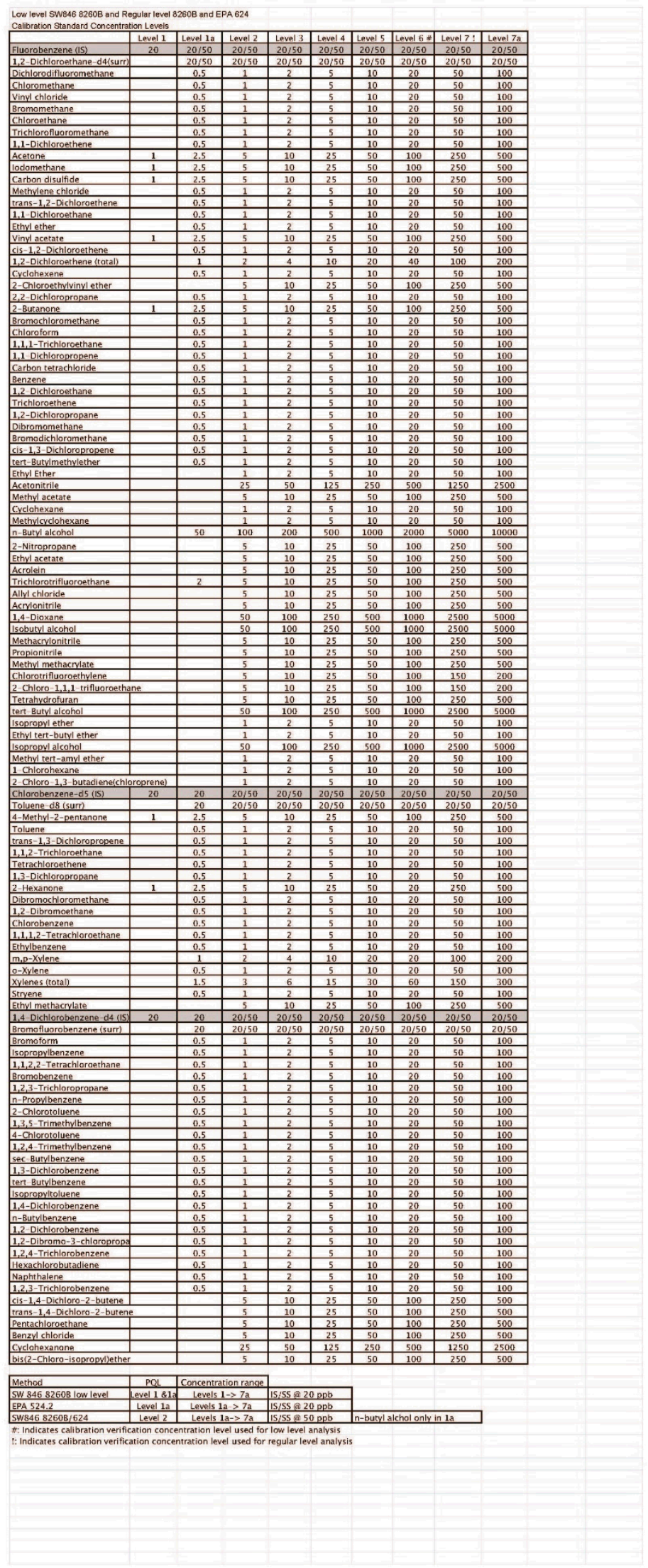

Page 45 of 151 SDG: 528429 


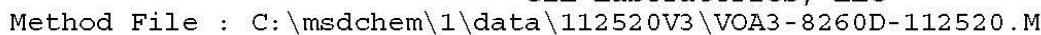

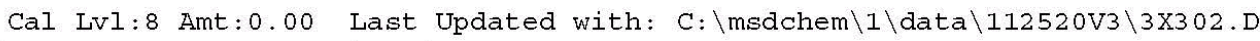

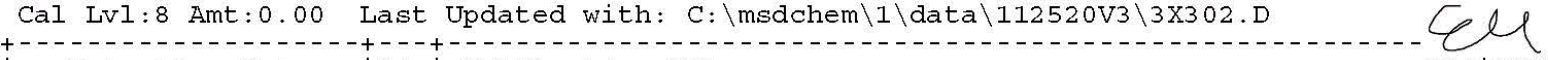

| Injection Date |Mix| Calibration File $11 / 30 / 2020$

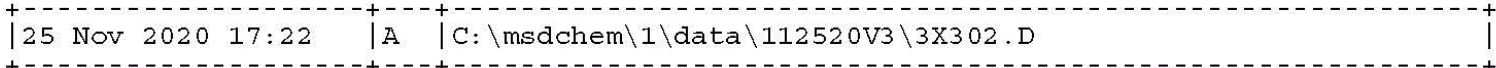

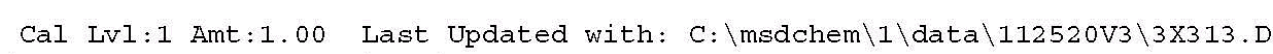

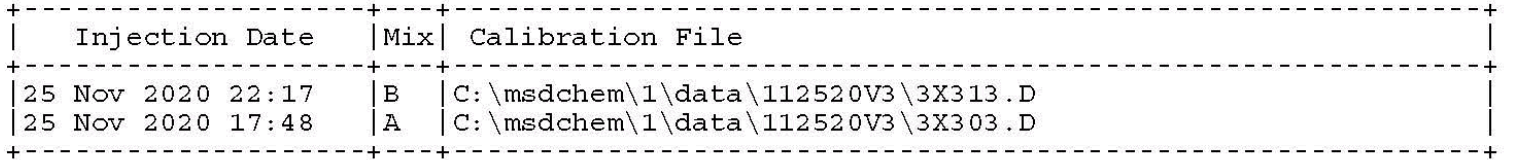

A $\mid$ C: $\backslash$ msdchem $\backslash 1 \backslash$ data $\backslash 112520$ V3 $\backslash 3 \times 303 . D$

Cal Lvl:2 Amt:2.00 Last Updated with: C: \msdchem $\backslash 1 \backslash$ data $\backslash 112520 \mathrm{~V} 3 \backslash 3 \times 314 . \mathrm{D}$

Injection Date |Mix| Calibration File

$+---$

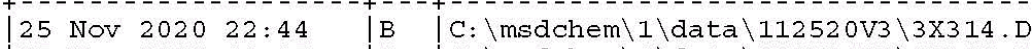

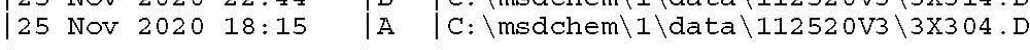

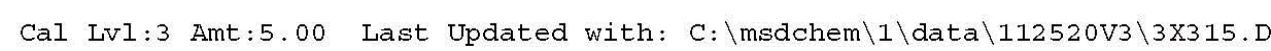

Injection Date |Mix| Calibration File

(- Injection Date

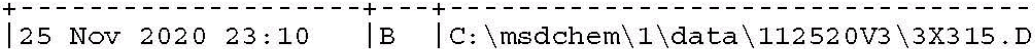

25 Nov $202018: 42 \quad \mid$ A $\mid$ C: $\backslash$ msdchem $\backslash 1 \backslash$ data $\backslash 112520$ V3 $\backslash 3 \times 305 . D$

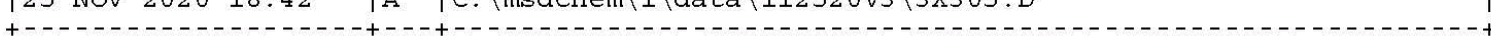

Cal Lvl:4 Amt:10.00 Last Updated with: C: \msdchem \1 \data \112520V3\3X316.D

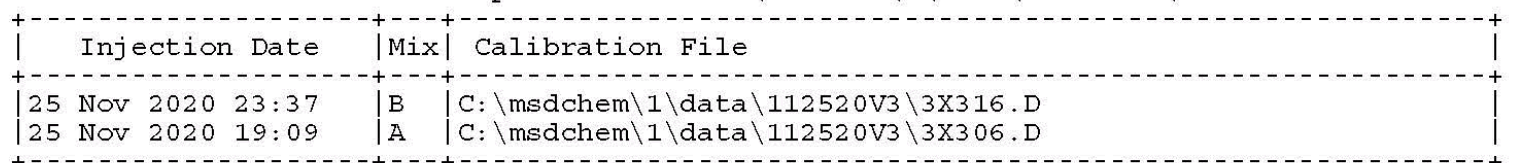

Cal Lvl:5 Amt:20.00 Last Updated with: C: \msdchem \1 \data \112520V3\3X317.D

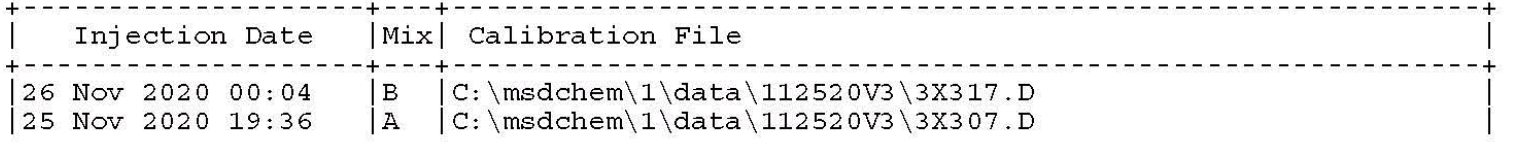

25 Nov 2020 19:36 |A $\mid$ C: $\backslash$ msdchem $\backslash 1 \backslash$ data $\backslash 112520 \mathrm{~V} \backslash 33 \times 307 . D$

Cal Lvl:6 Amt:50.00 Last Updated with: C: \msdchem \1 \data \112520V3\3X318.D

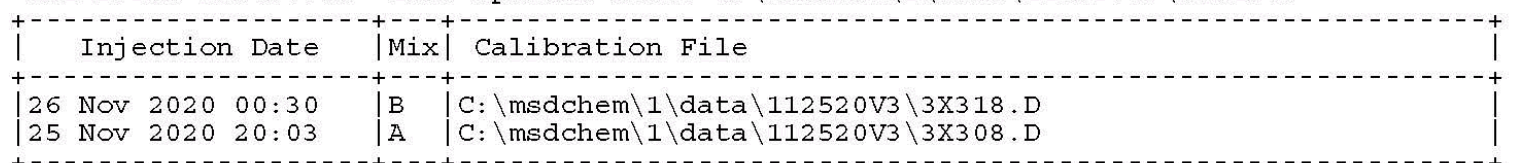

Cal Lvl:7 Amt:100.00 Last Updated with: C: \msdchem $\backslash 1 \backslash$ data $\backslash 112520 \mathrm{~V} 3 \backslash 3 \times 320 . \mathrm{D}$

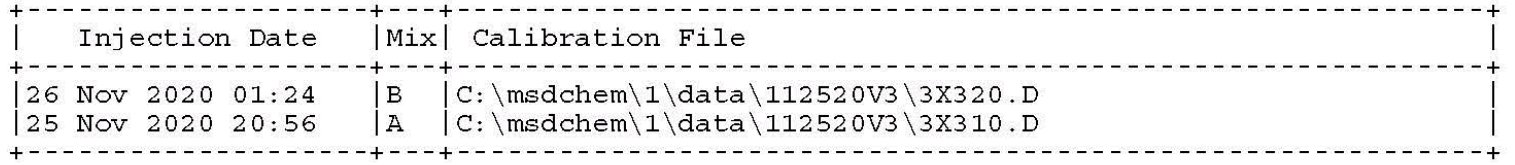

Cal Lvl:9 Amt:80.00 Last Updated with: C: \msdchem \1 \data \112520V3\3X319.D

Injection Date |Mix| Calibration File
$\mid 26$ Nov 2020 00:58 |B |C: $\backslash$ msdchem $\backslash 1 \backslash$ data $\backslash 112520 \mathrm{~V} 3 \backslash 3 \times 319 . \mathrm{D}$

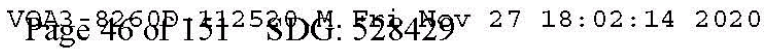




$$
\begin{aligned}
& \text { Calibration History Report VOA3 } \\
& \text { GEL Laboratories, LLC }
\end{aligned}
$$

Method File : C: \msdchem \1\data \112520V3 \VOA3-8260D-112520.M

Last Update : Fri Nov 27 17:58:59 2020

Integrator : (RTE Integrator)

Response via : Initial Calibration

| 25 Nov $202020: 30 \quad$ |A |C: \msdchem \1 \data \112520V3 \3X309.D

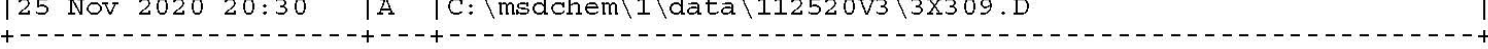

VOA3-8260D-112520.M Fri NOV $27 \quad 18: 02: 172020$ 

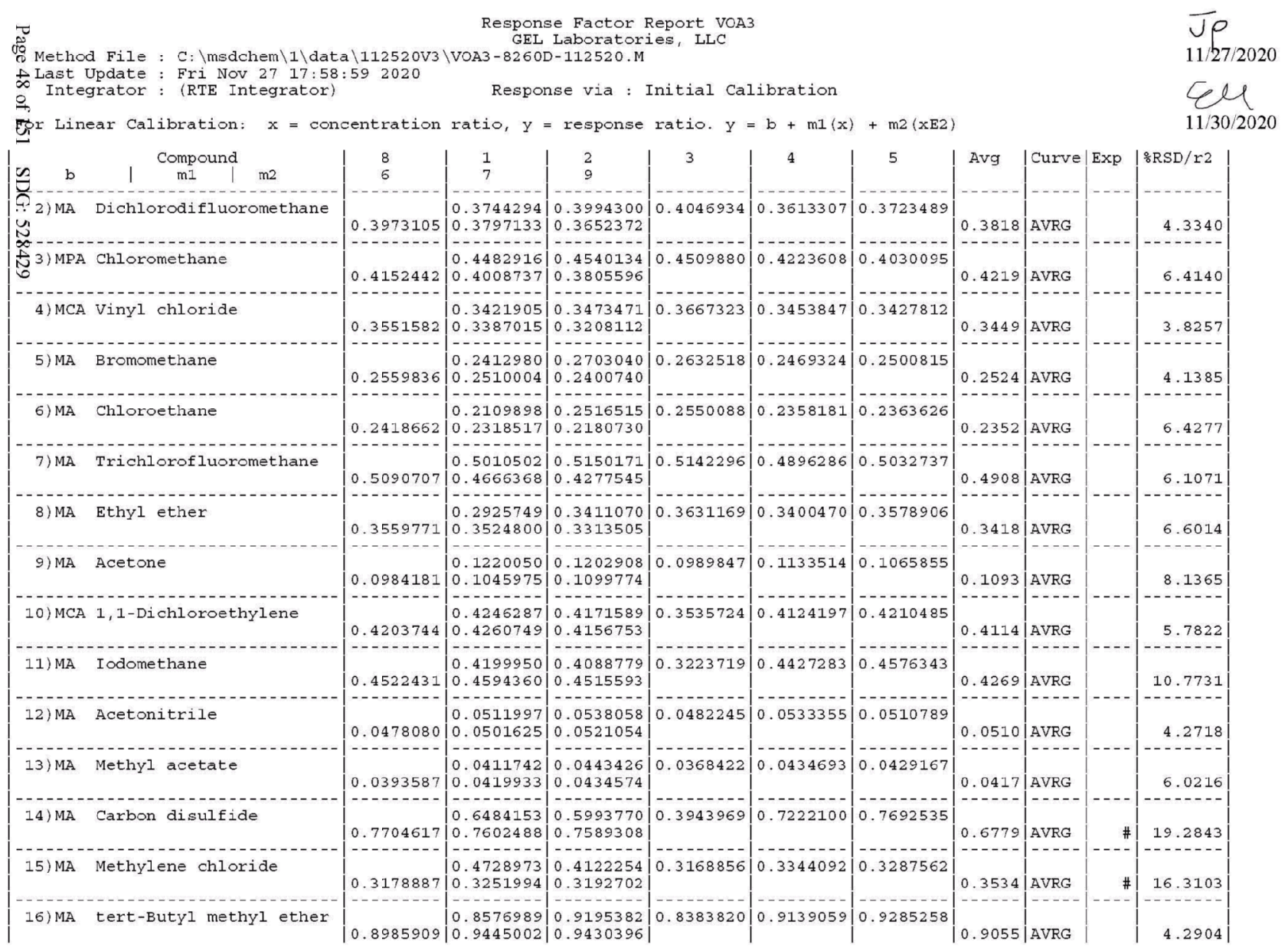

VOA3-8260D-112520.M Fri Nov 27 18:02:14 2020

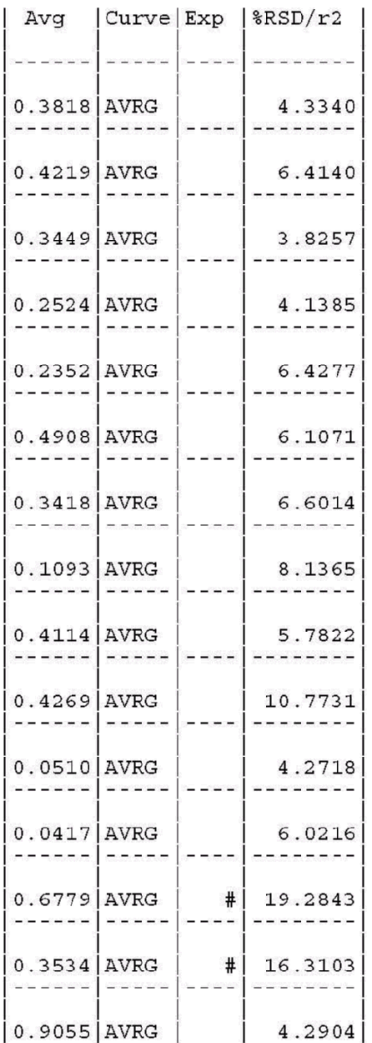

Page: 1 


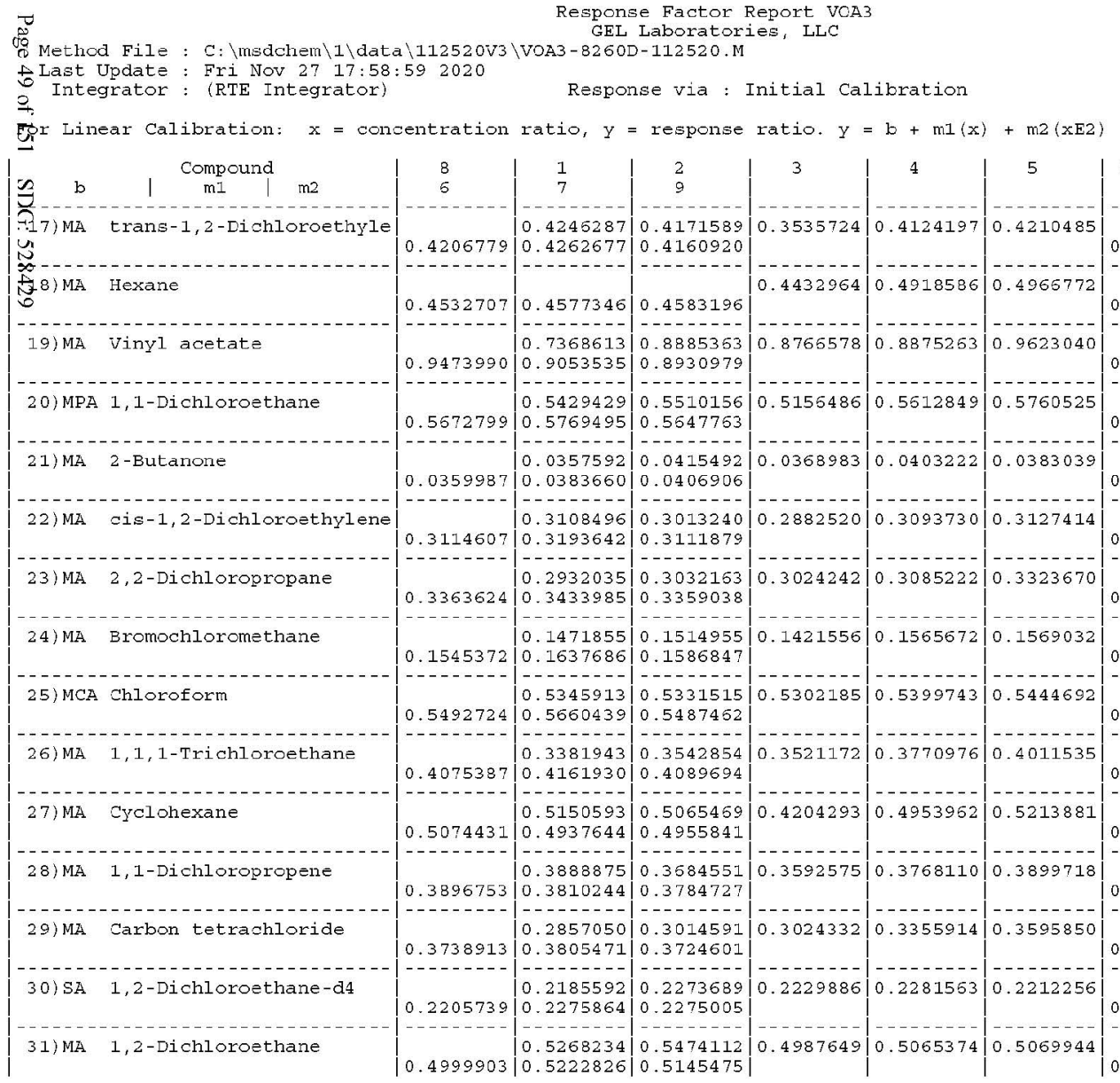

VOA3-8260D-112520.M Fri Nov 27 18:02:14 2020

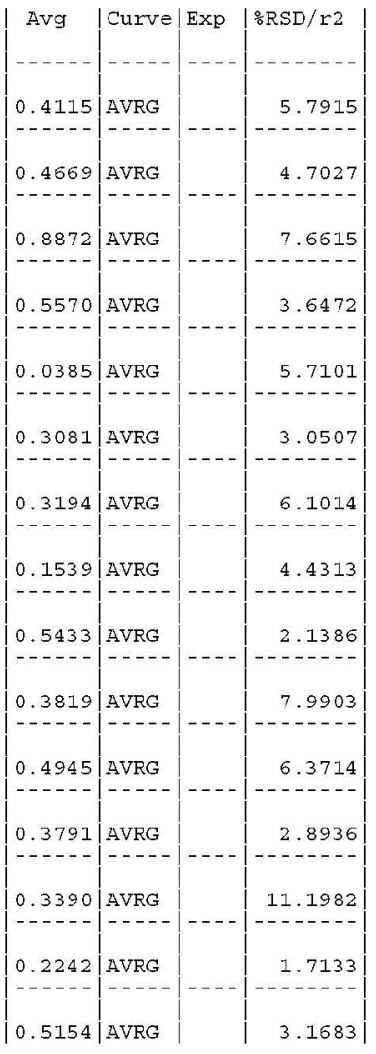

Fage: 2 


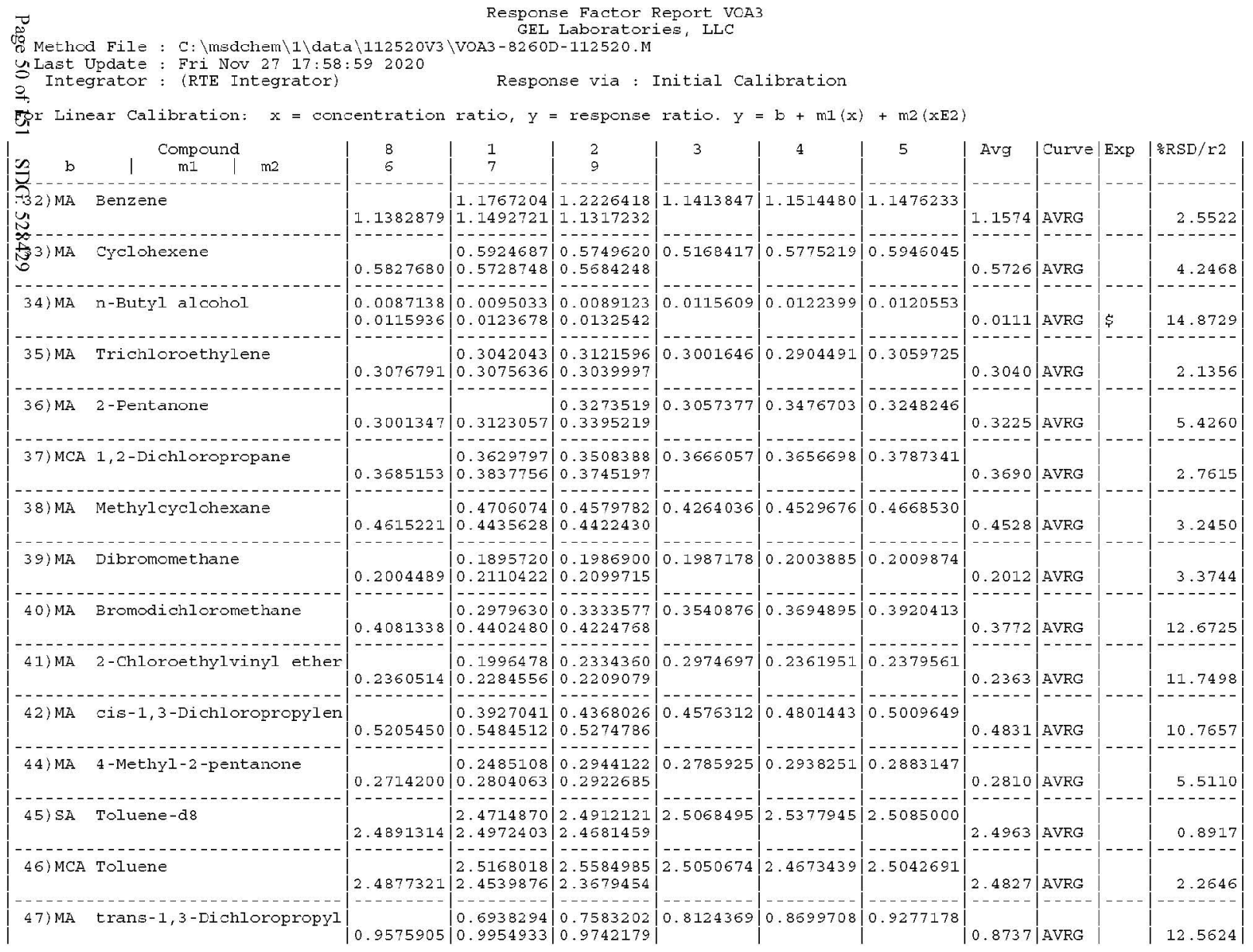

VOA3-8260D-112520.M Fri Nov 27 18:02:14 2020

Fage: 3 

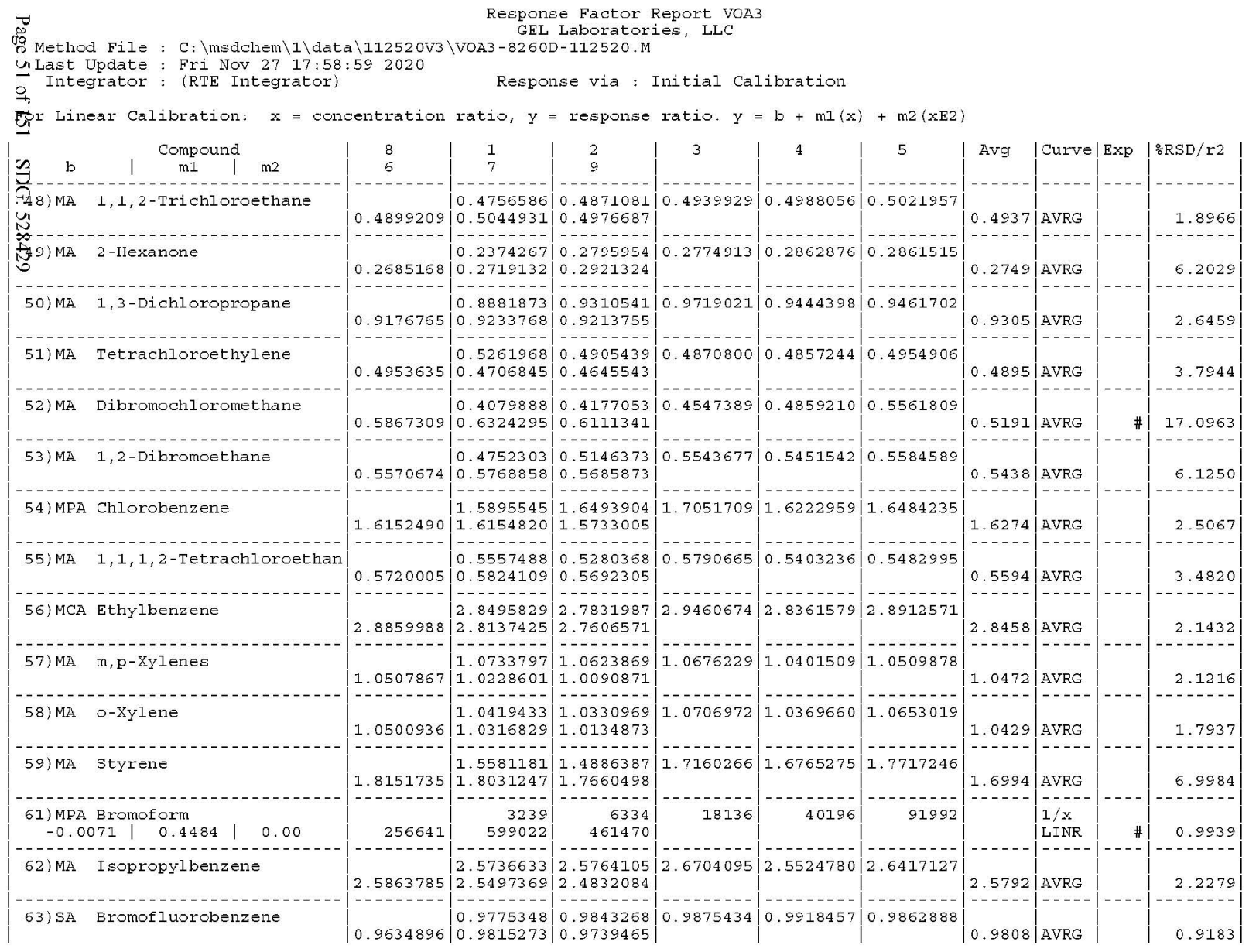

VOA3-8260D-112520.M Fri Nov 27 18:02:14 2020

Fage: 4 
7 Response Factor Report VOA3

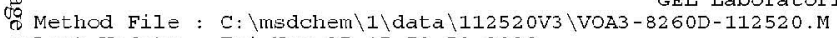

U Last Update : Fri Nov 27 17:58:59 2020

Integrator : (RTE Integrator)

Response via : Initial Calibration

Eir Linear Calibration: $x=$ concentration ratio, $y=$ response ratio $y=b+m 1(x)+m 2(x E 2)$

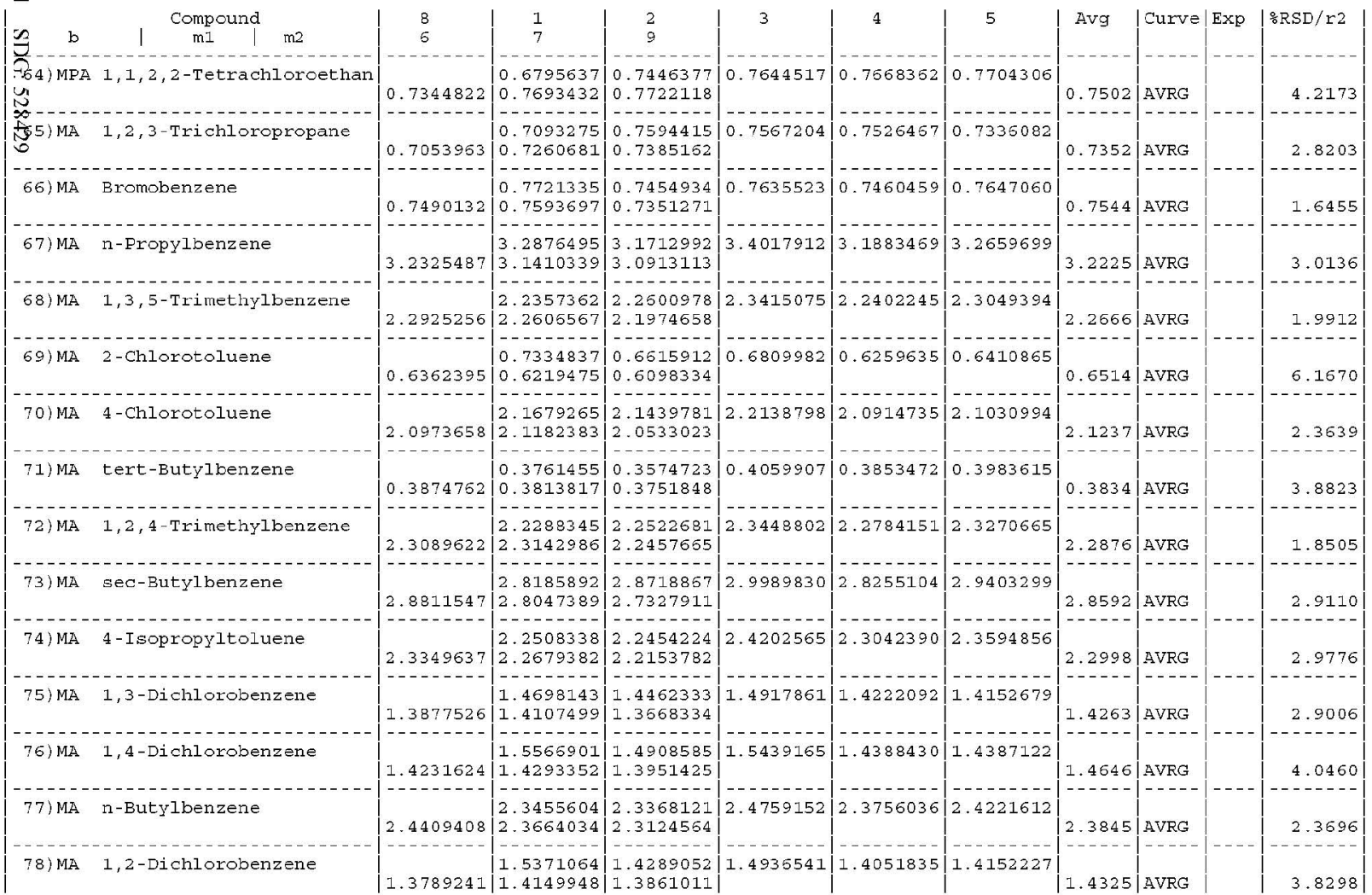

VOA3-8260D-112520.M Fri Nov 27 18:02:14 2020

Fage: 5 


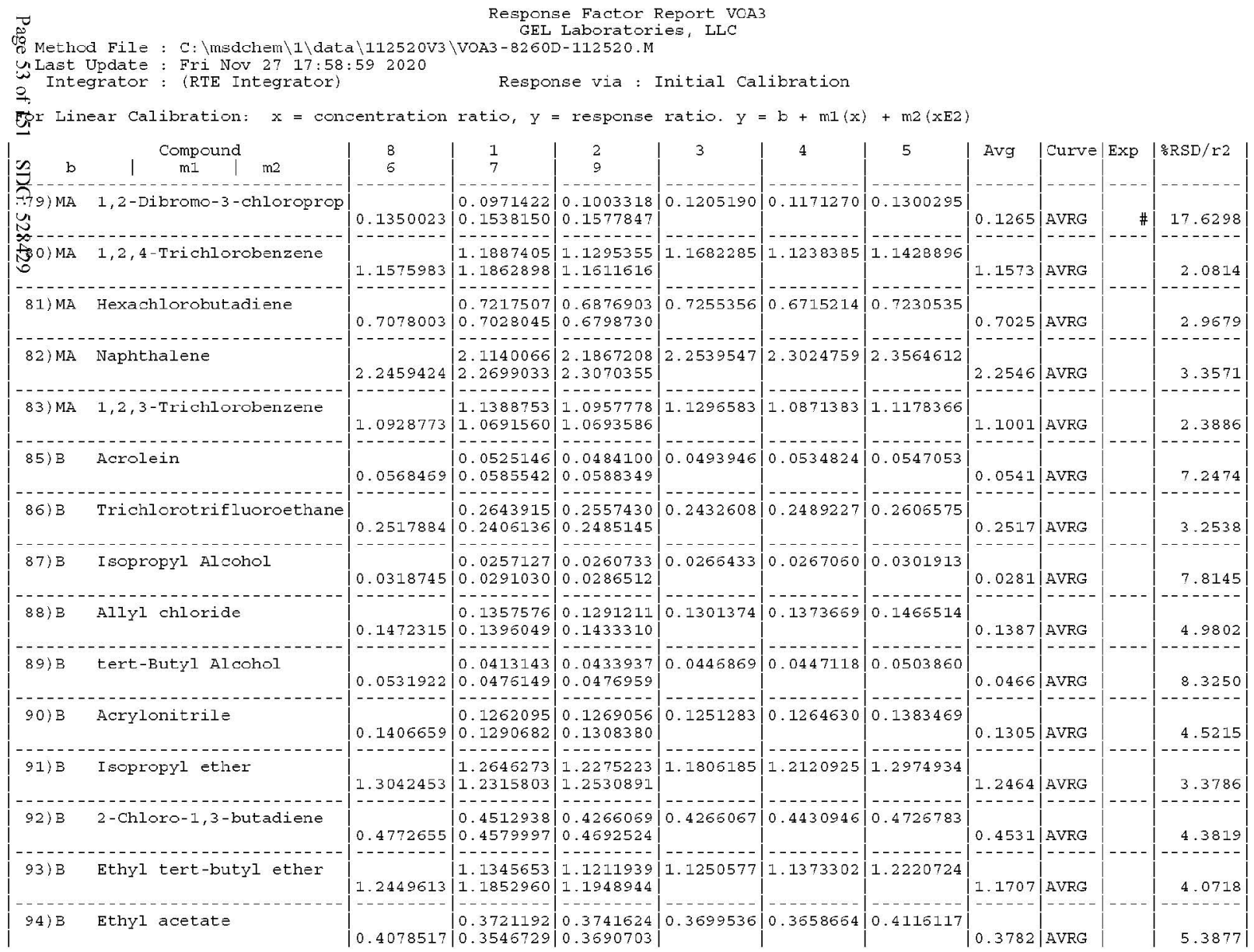

VOA3-8260D-112520.M Fri NOv 27 18:02:14 2020

Fage: 5 


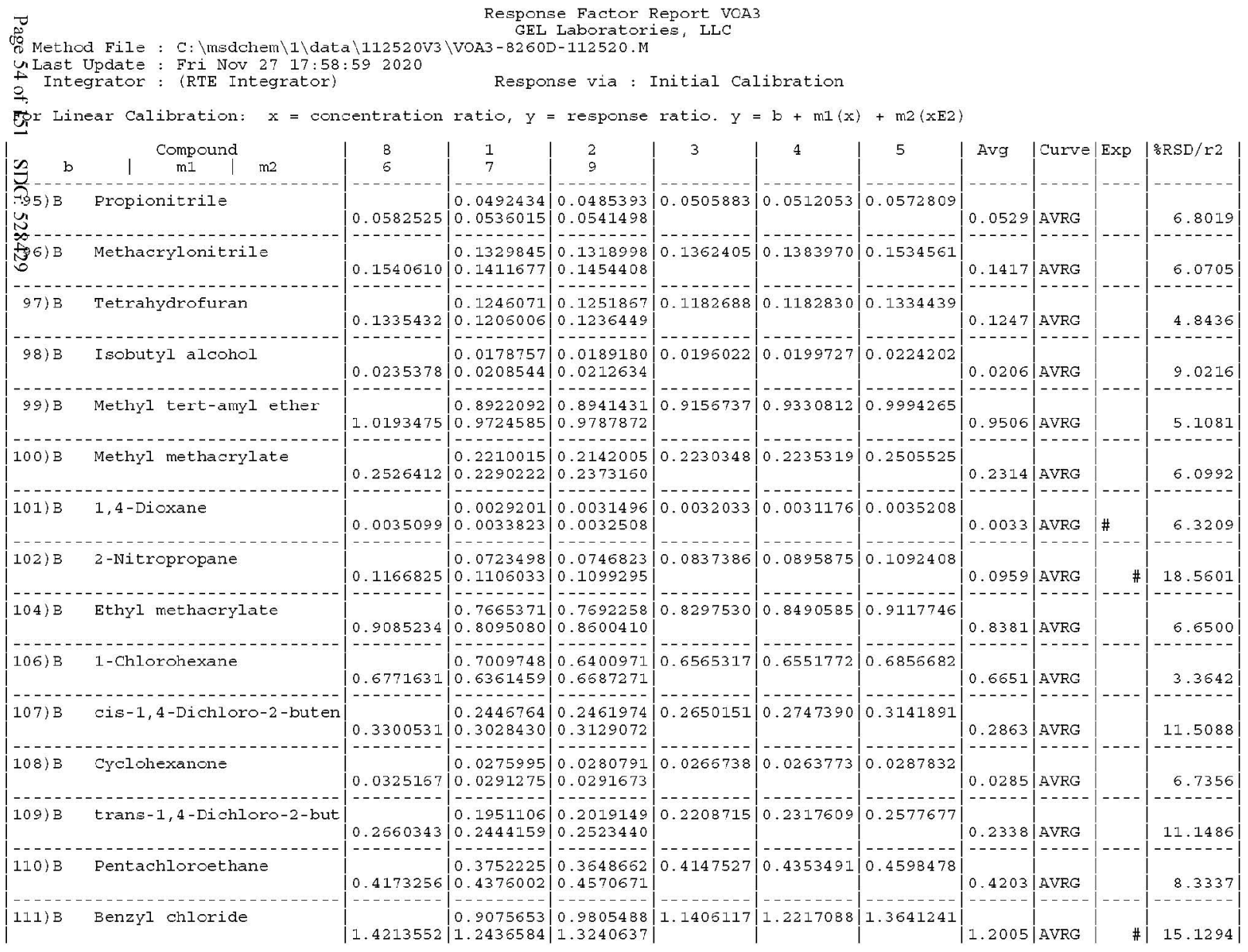

VOA3-8260D-112520.M Fri NOv 27 18:02:14 2020

Fage: 7 
7) Response Factor Report VOA3

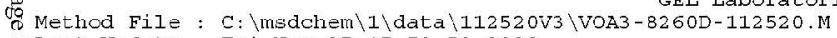

U Last Update : Fri Nov 27 17:58:59 2020

Integrator : (RTE Integrator)

Response via : Initial Calibration

Eir Linear Calibration: $x=$ concentration ratio, $y=$ response ratio. $y=b+m 1(x)+m 2(x E 2)$

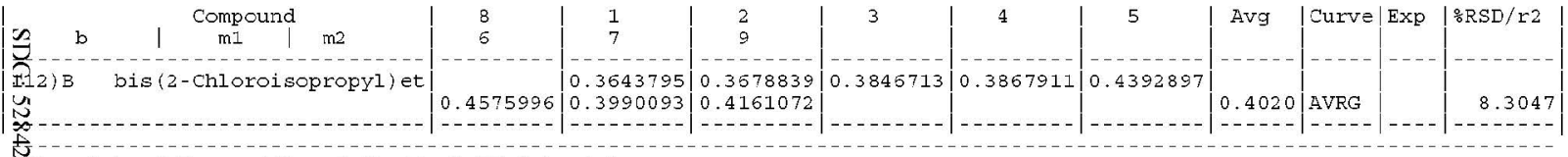

(a) = Out of Range $(\$)=$ Individual $R F$ out of Range

AVRG $=$ Average, LINR $=$ Linear Regression, $1 / x=$ the inverse of concentration, $1 / x^{\wedge} 2=$ the inverse square of concentration 
Calibration History Report VOA2

GEL Laboratories, LLC

Method File : D: \MSDCHEM \1\Data\101320V2.b\VOA2-8260D-101320.M

$\checkmark p$

Last Update : Thu Oct 15 16:56:20 2020

Response via : Initial Calibration

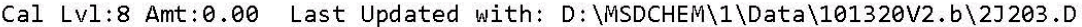

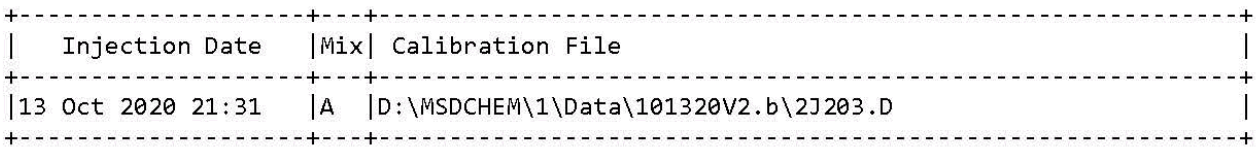

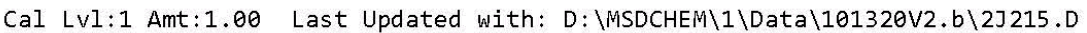

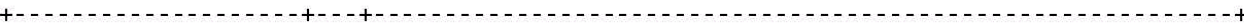

| Injection Date $\mid$ Mix| Calibration File |

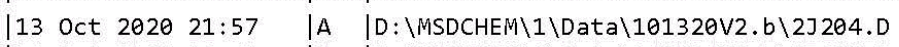

|14 Oct $2020 \quad 02: 40 \quad|B \quad| D: \backslash M S D C H E M \backslash 1 \backslash D a t a \backslash 101320 V 2 . b \backslash 2 J 215 . D$

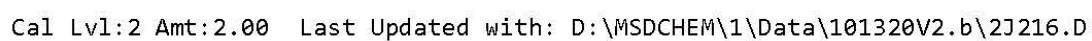

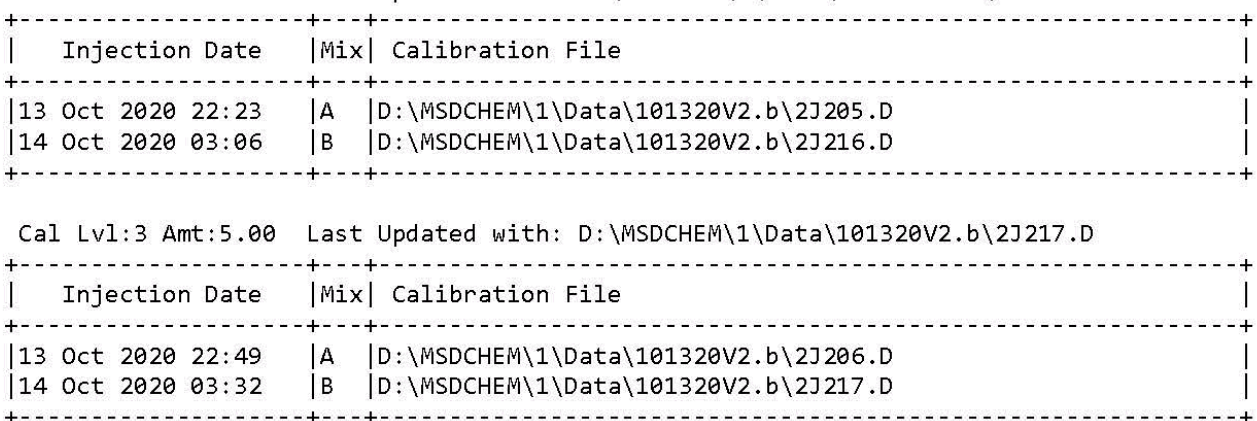

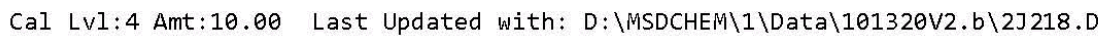

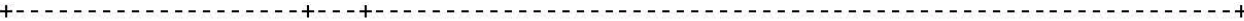
Injection Date $\mid$ Mix| Calibration File

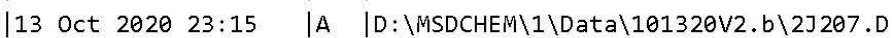

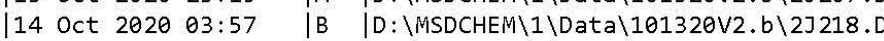

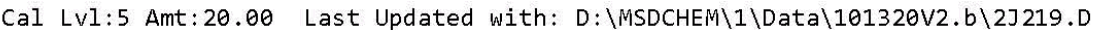

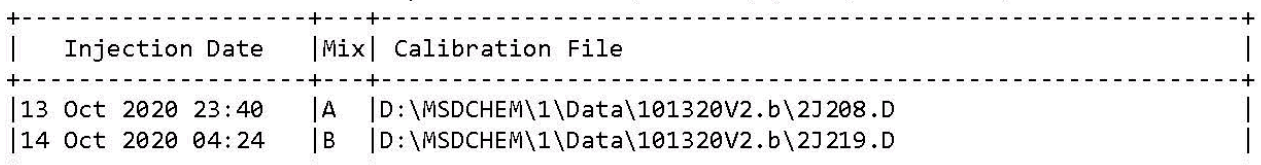

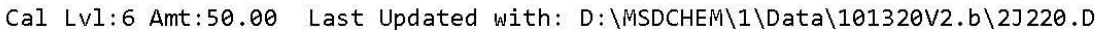

+

| Injection Date $\mid$ Mix| Calibration File

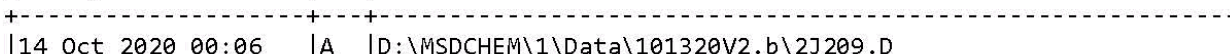

14 oct $202004: 49 \quad|B \quad| D: \backslash M S D C H E M \backslash 1 \backslash D a t a \backslash 101320 \vee 2 . b \backslash 2 J 220 . D$

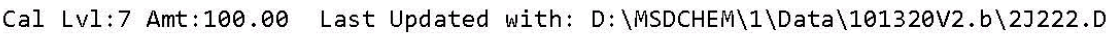

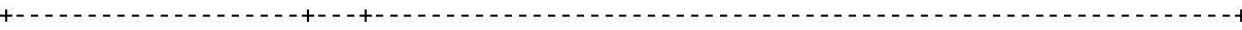

| Injection Date $\mid$ Mix| Calibration File

+14-1-10

|14 Oct $202 \theta \theta 0: 58 \quad|A \quad| D: \backslash M S D C H E M \backslash 1 \backslash D a t a \backslash 10132 \theta V 2 . b \backslash 2 J 211 . D$

|14 Oct $2020 \quad 05: 41 \quad|B \quad| D: \backslash M S D C H E M \backslash 1 \backslash D a t a \backslash 101320 V 2 . b \backslash 2 J 222 . D$

Page 56 of 151 SDG: 528429 
Calibration History Report VOA2

GEL Laboratories, LLC

Method File : D: \MSDCHEM\1\Data\101320V2.b\VOA2-8260D-101320.M

Last Update : Thu Oct 15 16:56:20 2020

Integrator : (RTE Integrator)

Response via : Initial Calibration

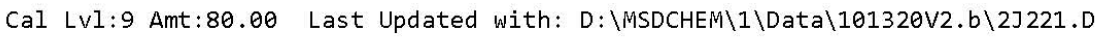

+

| Injection Date $\mid$ Mix| Calibration File |

114 Oct 2020

$\mid 14$ Oct $202000: 32 \quad|A \quad| D: \backslash M S D C H E M \backslash 1 \backslash D a t a \backslash 101320 V 2 . b \backslash 2 J 210$.D

|14 Oct $2020 \quad 05: 15 \quad|B \quad| D: \backslash M S D C H E M \backslash 1 \backslash D a t a \backslash 101320 \vee 2 . b \backslash 2 J 221 . D$

+-1.

VOA2-8260D-101320.M Thu Oct 15 16:59:54 2020

VOA2-8260D-101320.M Thu Oct 15 16:59:51 2020

Page 57 of 151 SDG: 528429 


\begin{tabular}{|c|c|c|}
\hline $\begin{array}{l}70 \\
\text { ¿ी. Method File }\end{array}$ & 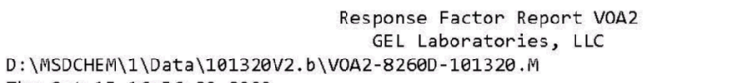 & $\begin{array}{l}\overline{J P}_{10 / 15 / 2020} \\
\end{array}$ \\
\hline $\begin{array}{l}\mathbb{S}_{\text {Last Update }} \\
0 \text { Integrator }\end{array}$ & $\begin{array}{l}\text { Thu Oct } 15 \text { 16:56:28 } 2028 \\
\text { (RTE Integrator) } \quad \text { Response via : Initial Calibration }\end{array}$ & EM \\
\hline
\end{tabular}

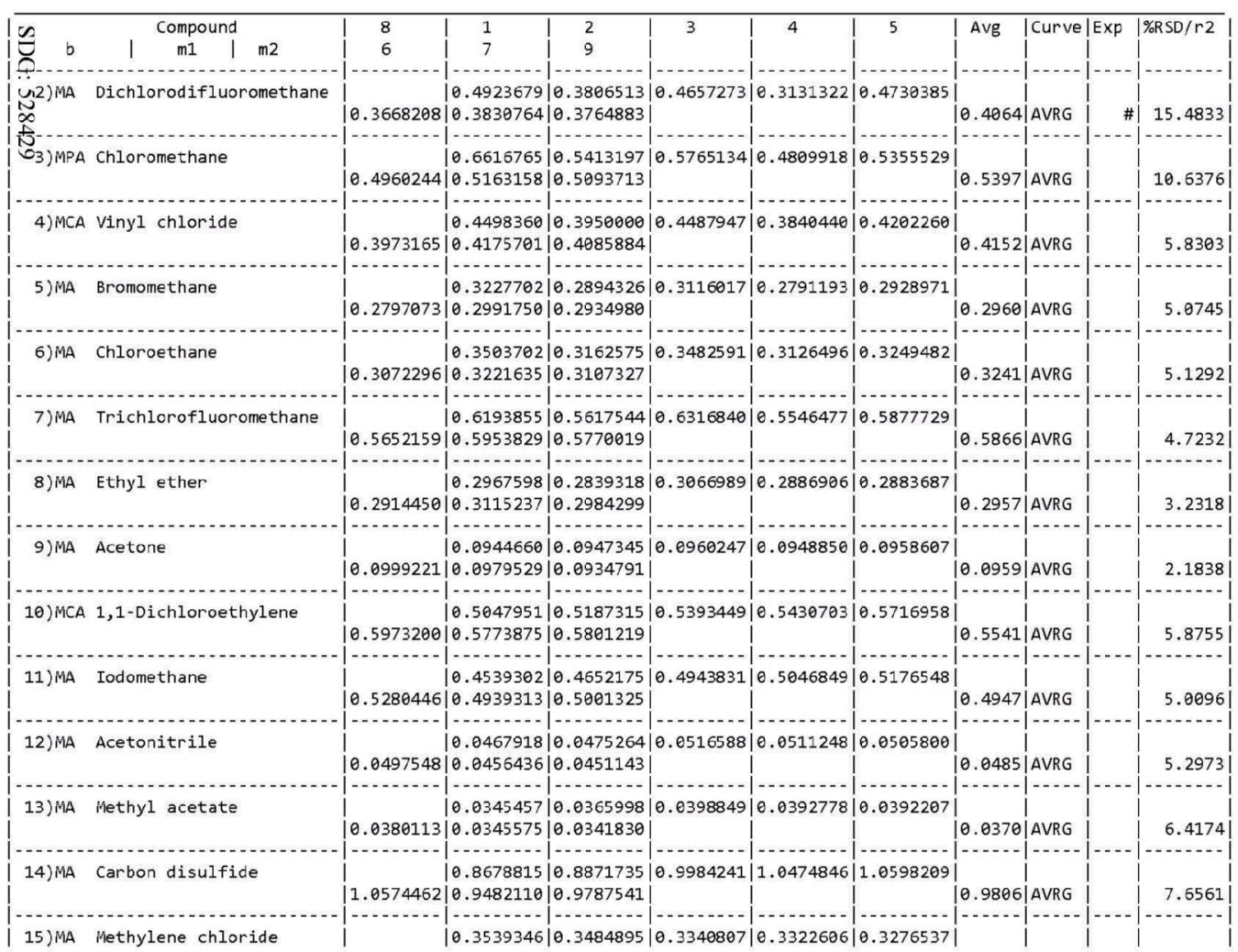




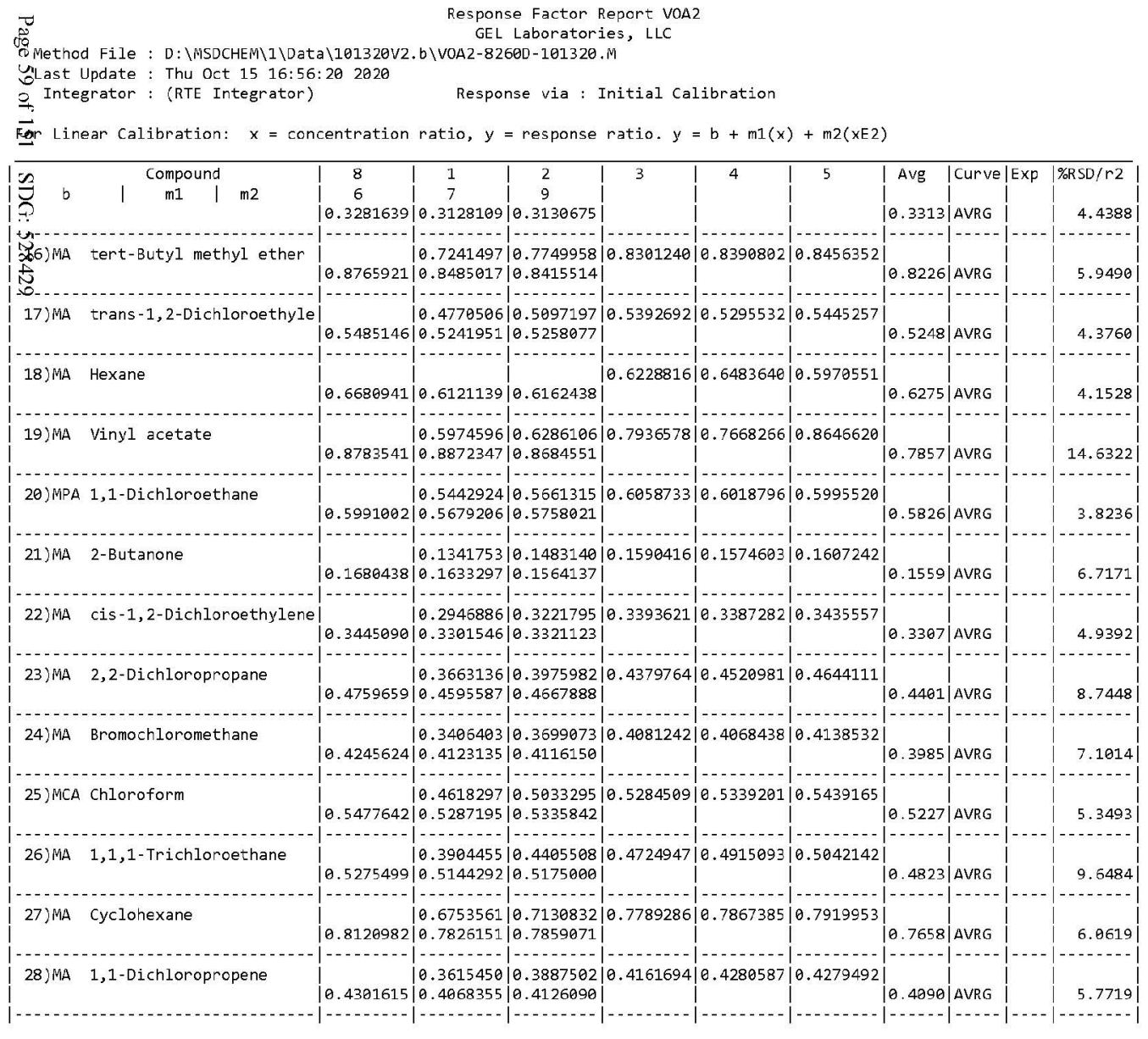

VOA2-8269D-101320. M Thu Oct 15 16:59:51 2820

Page: 2 


\begin{tabular}{|c|c|c|c|c|c|c|c|c|c|c|}
\hline 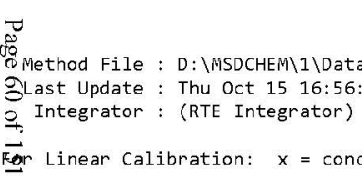 & $\begin{array}{l}\text { a)101320V2. } \\
: 202020 \\
\text { centration }\end{array}$ & $\begin{array}{r}\text { Respons } \\
\text { GEL } \\
. b \backslash \text { VOA2-826 } \\
\text { Respon } \\
\text { ratio, } y=\end{array}$ & $\begin{array}{l}\text { se Factor R } \\
\text { Laboratori } \\
600-101320 . \\
\text { nse via : I }\end{array}$ & $\begin{array}{l}\text { Repart VOA } \\
\text { ies, LLC } \\
\text { M } \\
\text { Initial Cal }\end{array}$ & $=b+m 1(x)$ & $+m 2(x E 2$ & & & & \\
\hline Compound & 8 & 1 & 2 & 3 & 4 & 5 & Avg & |Curve & & |\%RSD/r2 \\
\hline $\begin{array}{lllll} & b & \mid & m 1 & \mathrm{~m} 2\end{array}$ & 6 & 7 & 9 & & & & & & & \\
\hline . & & $|0.3244079|$ & $|0.3538966|$ & $|0.4076415|$ & $|0.4194573|$ & 0.4385529 & & & & \\
\hline & $|0.4531734|$ & $\mid 0.4381848$ & $|0.4430488|$ & & & & $\mid 0.4098$ & |AVRG & & 11.3465 \\
\hline (3))SA 1,2-Dichloroethane-d4 & $\mid$ & $|0.1431990|$ & $|0.1440745|$ & $|0.1477747|$ & $|e .1487567|$ & 0.1494503 & & & & - - n \\
\hline & $|0.1512627|$ & $|0.1478160|$ & $|0.1476225|$ & & & & $|0.1475|$ & AVRG & & 1.8114 \\
\hline 31)MA 1,2-Dichloroethane & $|-\cdots+\cdots-|$ & $|-1 .-1 .-10|$ & ||$-0.4257105 \mid$ & $|0.4511988|$ & $|-10.4440408|$ & 0.4409658 & & $\mid-\ldots$ & & $\cdots$ \\
\hline & 0.4445715 & $|0.4192629|$ & $|0.4249093|$ & & & & $|0.4326|$ & AVRG & & 3.3448 \\
\hline 32) MA Benzene & & $\left|\begin{array}{l}|c| \\
\mid 1.1091041\end{array}\right|$ & $|-1.1 .1 .1|$ & 1.2071751 & $\mid-2001304$ & 1.1817148 & & & & \\
\hline SL TIA DETILETIE & $|1.1758724|$ & $|1.1032271|$ & $|1.1233475|$ & & & & $\mid 1.1607$ & AVRG & & 3.6156 \\
\hline (3) & $\mid-\ldots+\ldots$ & $|-1-2 .-1|$ & $|-1-2-1|$ & $|-1-2 .-1|$ & - & $-1.2 .-1$ & $\mid-\ldots$ & $-\cdots$ & $1-$ & $|-\ldots+n|$ \\
\hline 33) MA Cyclohexene & $|0.6604659|$ & $|0.5615845|$ & \begin{tabular}{|l|}
$|0.5992764|$ \\
$|0.6328497|$
\end{tabular} & $\mid 0.6486071$ & $|0.6562321|$ & 0.6547365 & $\mid 0.6296$ & SAVRG & & 5.4545 \\
\hline & $|-\ldots \ldots|$ & $|-\ldots \ldots|$ & $|-\ldots-\ldots|$ & & & & & & & \\
\hline 34) MA n-Butyl alcohol & 7682 & | 15772 & $37167 \mid$ & 109700 & 227502 & 472300 & & $1 / x$ & & \\
\hline$-0.0081|\quad 0.0117| \quad 0.00$ & $1271375 \mid$ & 2511586 & 1884140 & & & & & LINR & $\#$ & 0.9980 \\
\hline 35)MA Trichloroethylene & $\mid$ & $|0.2836582|$ & $\mid$\begin{tabular}{|c|}
$\mid$ \\
$|0.3954667|$ \\
$|0.3939062|$
\end{tabular} & $\mid 0.3121412$ & $|0.3046775|$ & 0.3038318 & $|0.3033|$ & AVRG & & 2.9348 \\
\hline 36)MA 2-Pentanone & $|0.3000709|$ & $|0.2890405|$ & $|0.2624626|$ & $\mid$ & $|0.2800003|$ & 0.2744335 & $|0.2863|$ & AVRG & & 4.1971 \\
\hline 37)MCA 1,2-Dichloropropane & & $\mid 0.3179535$ & $\mid 0.3356388$ & $|0.3457604|$ & $|0.3397691|$ & 0.3389242 & & & & \\
\hline & $|0.3417608|$ & $|0.3254094|$ & $|0.3299417|$ & & & & $|0.3344|$ & AVRG & & 2.7808 \\
\hline 38) MA Plethylcyclahexane & $|0.5993044|$ & $|0.5481458|$ & $|0.5899603|$ & 0.6097728 & $|0.5993011|$ & 0.5995903 & $\mid 0.5854$ & $A V R G$ & & 3.6689 \\
\hline & & & & & & & & & & \\
\hline 39) MA Dibromomethane & $|0.1744722|$ & $|0.1500898|$ & $|0.1612068|$ & $\mid 0.1667138$ & $|e .1684179|$ & $\theta .1687941$ & $|0.1659|$ & AVRG & & 4.4283 \\
\hline & $|-\ldots+\ldots|$ & $|-\ldots \ldots|$ & $|-\ldots+\cdots|$ & & & & & & $|---|$ & $|-\ldots \ldots|$ \\
\hline 40) MA Bromodichloromethane & $|0.4060277|$ & $|0.2786006|$ & $\begin{array}{l}|0.3141508| \\
|0.3993759|\end{array}$ & $\mid 0.3445867$ & $|0.3613956|$ & 0.3784322 & $|0.3604|$ & AVRG & & 12.6765 \\
\hline 41)MA 2-Chlorothyluinylether & $\mid \cdots-\ldots$ & $|-\ldots-1 .-1|$ & 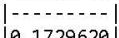 & $|-1-1-1|$ & $|-1-1-1|$ & | & - & $\ldots$ & $|-\cdots|$ & $\ldots$ \\
\hline 41) MA 2-Chloroethylvinyl etner & |0.1912389| - n & $|0.1659562|$ & $|0.1811978|$ & 10.2526310 & $10.193 / 4321$ & 10.194593 & $|0.1922|$ & AVRRG & & 13.7538 \\
\hline 42)MA cis-1,3-Dichloropropylen & & $|0.3169901|$ & $|0.3751973|$ & $|0.4152797|$ & $\mid$\begin{tabular}{|c|}
$\mid$ \\
$\mid$
\end{tabular} & 0.4539441 & & & $\mid--$ & \\
\hline & $|0.4833766|$ & $|0.4664968|$ & $|0.4697178|$ & & & & $|0.4269|$ & AVRG & & 13.2108 \\
\hline
\end{tabular}




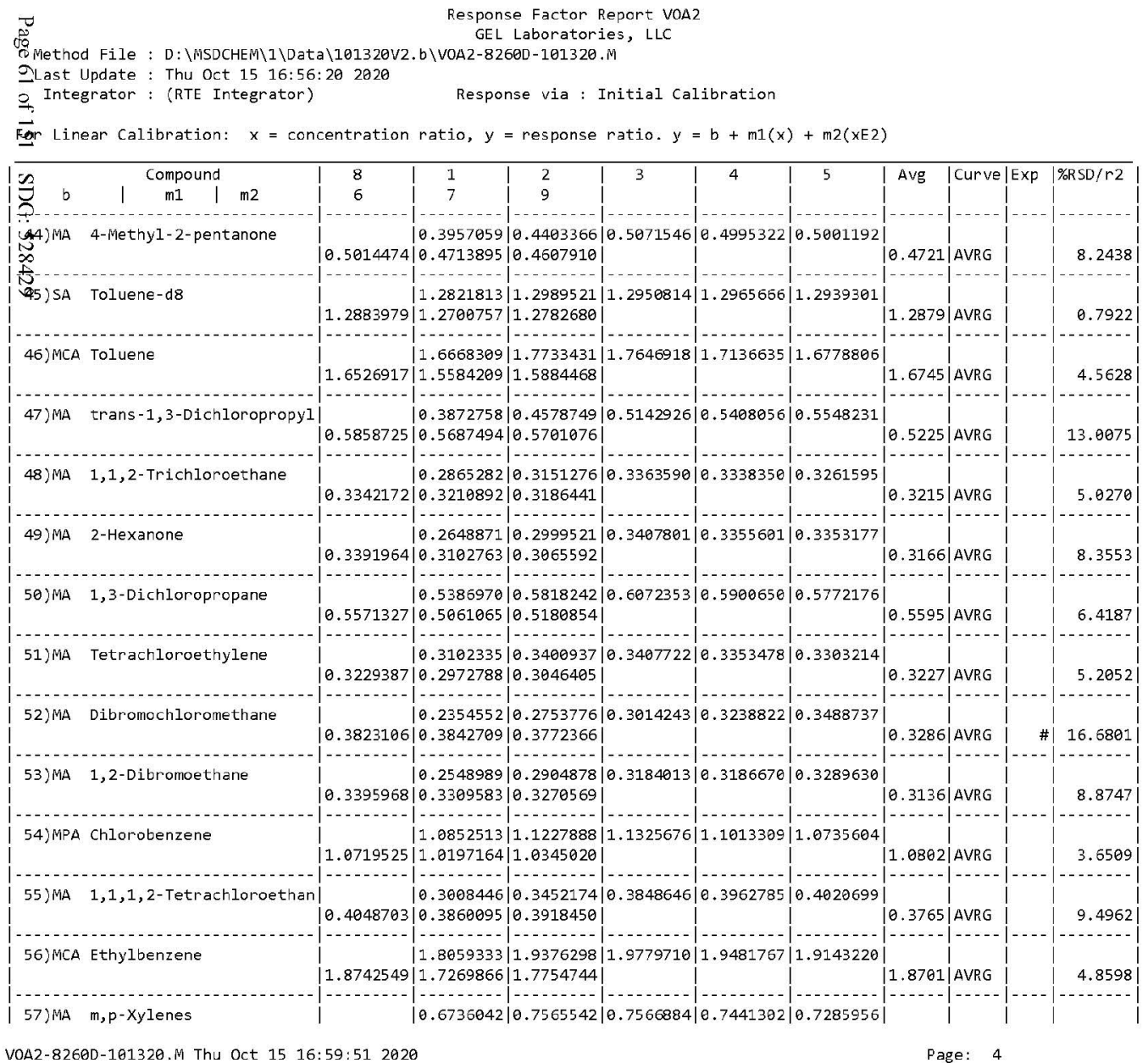




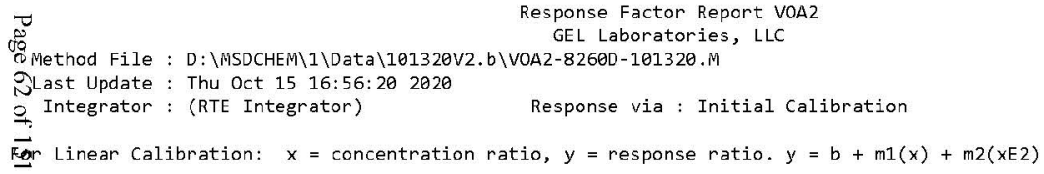




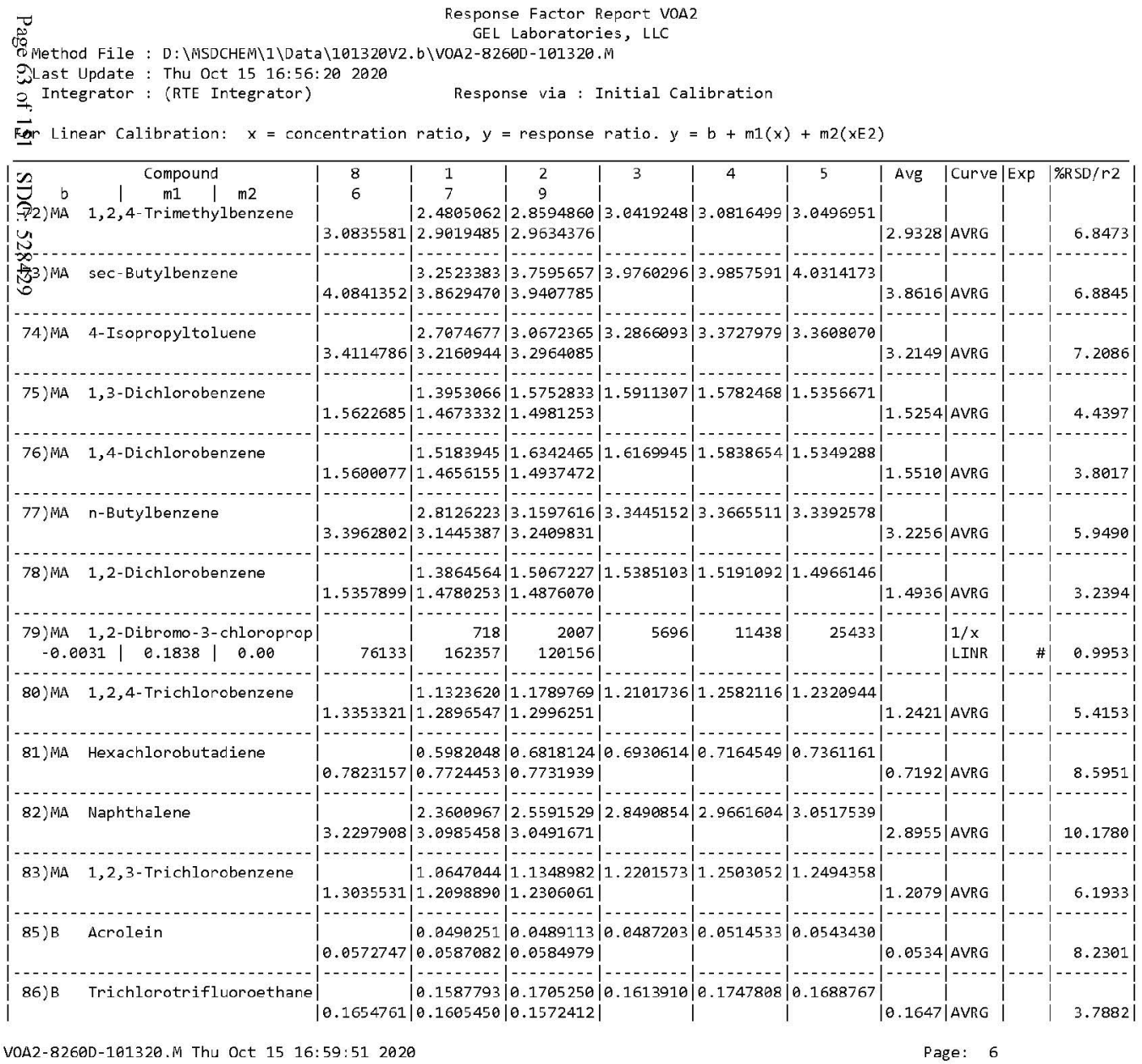




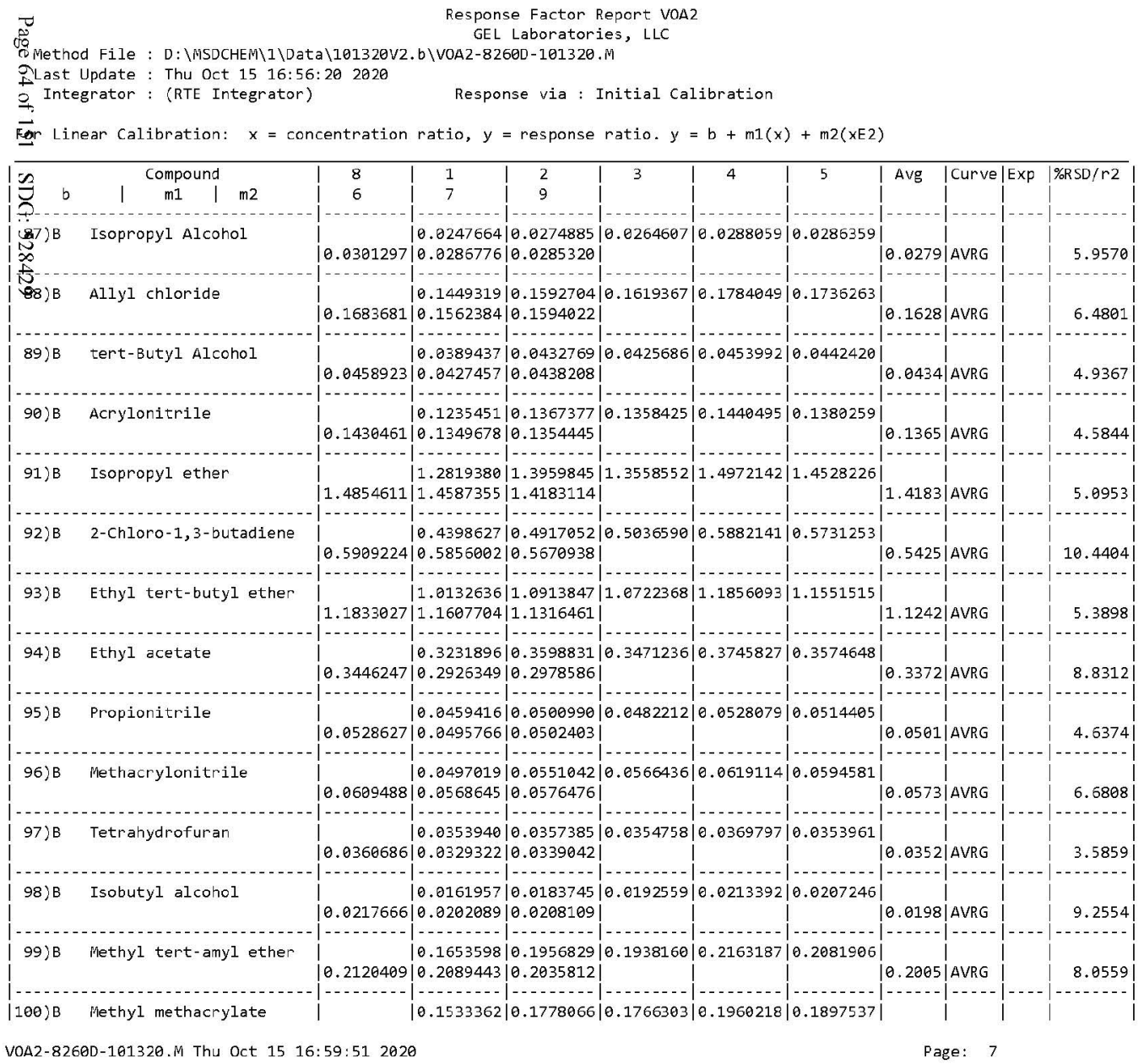




\begin{tabular}{|c|c|c|c|c|c|c|c|c|c|c|}
\hline 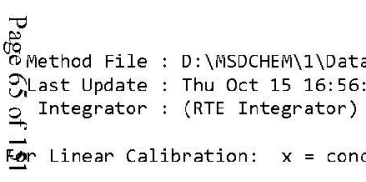 & $\begin{array}{l}\text { a)101320V2. } \\
: 202020 \\
\text { centration }\end{array}$ & $\begin{array}{r}\text { Respons } \\
\text { GEL } \\
\text { b\VOA2-826 } \\
\text { Respor } \\
\text { ratio, } y=\end{array}$ & $\begin{array}{l}\text { se Factor } \\
\text { Laborator } \\
600-101320 \\
\text { nse via : }\end{array}$ & $\begin{array}{l}\text { Repart VOAt } \\
\text { ies, LLC } \\
\text { M Mitial Cal }\end{array}$ & $=b+m 1(x)$ & $+m 2(x E 2)$ & & & & \\
\hline Compound & 8 & 1 & 2 & 3 & 4 & 5 & Avg & |Curve & & |\%RSD/r2 \\
\hline $\begin{array}{llllll}Ð & b & \mathrm{l} & \mathrm{m} 1 & \mathrm{~m} 2\end{array}$ & $\left|\begin{array}{c}6 \\
\mid 0.1898313\end{array}\right|$ & $\mid \begin{array}{c}7 \\
\mid 0.1743592\end{array}$ & $\begin{array}{c}9 \\
0.1803115\end{array}$ & & & & |0.1798| & & & 7.3052 \\
\hline $\begin{array}{l}1>B \quad 1,4-D i o x a n e \\
t\end{array}$ & $|0.0027234|$ & $\left|\begin{array}{|c|c|}\mid 0.0026059 \\
\mid 0.0025657\end{array}\right|$ & $\begin{array}{l}\mid 0.0028103 \\
\mid 0.0025947\end{array}$ & $|0.0026973|$ & $|0.0027999|$ & $|0.0027603|$ & 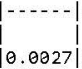 & AVVRG & & $\mid \cdots$ \\
\hline . & $|-\ldots \ldots|$ & |-...... & |..... & & & $|\cdots \ldots-\ldots|$ & $\mid \cdots-1$ & -... & & $|\ldots \ldots|$ \\
\hline $\begin{array}{l}\text { 102)B 2-Nitropropane } \\
-0.8067|0.0943| 0.80\end{array}$ & 502902 & $\begin{array}{r}5349 \\
967909\end{array}$ & $\begin{array}{r}12800 \\
582334\end{array}$ & 36061 & 89631 & $184906 \mid$ & & $\begin{array}{l}\mid 1 / x \\
\mid \operatorname{LINR}\end{array}$ & $\#$ & 0.9984 \\
\hline Ethyl methacrylate & $|0.4964863|$ & $|0.3951950|$ & 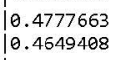 & $\mid 0.4849851$ & $|0.5405193|$ & $|0.5104186|$ & $|0.4767|$ & |AVRG & & 9.2374 \\
\hline 106)B 1-Chlorohexane & $|0.9563684|$ & $\left|\begin{array}{|c|}\mid 0.8174573 \\
\mid 0.9352085\end{array}\right|$ & $\begin{array}{l}0.8831658 \\
0.9118375\end{array}$ & $\mid 0.8738855$ & $|0.9905382|$ & $|0.9436135|$ & $|0.914 \theta|$ & |AVRG & & 5.9732 \\
\hline 107)B cis-1,4-Dichloro-2-buten & 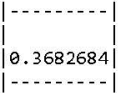 & $\left|\begin{array}{|l|}\mid-2556135 \\
\mid 0.3488974\end{array}\right|$ & $\mid \begin{array}{l}0.2936197 \\
0.3474118\end{array}$ & $|0.3102720|$ & |e.3549964| & $|0.3504023|$ & | & AVRG & & 11.7259 \\
\hline Cyclohexanone & $|0.0239876|$ & $\left|\begin{array}{l}0.0185095 \\
0.0233354\end{array}\right|$ & $\mid \begin{array}{l}0.0193860 \\
0.0237219\end{array}$ & 0.0203642 & $\mid 0.0221419$ & $\mid 0.0239996$ & 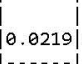 & AVRG & & 10.1040 \\
\hline 109)B trans-1,4-Dichloro-2-but & $|0.2990489|$ & $|0.2321073|$ & \begin{tabular}{|l|}
0.2723814 \\
0.2819923
\end{tabular} & $\mid 0.2757616$ & $\mid 0.3070408$ & $|0.2899607|$ & & & & 8.0664 \\
\hline 110)B Pentachloroethane & $|0.5483511|$ & $|0.4697920|$ & $\mid 0.4713664$ & $|0.5009918|$ & $|-0.5629288|$ & $|0.5421045|$ & $|0.5077|$ & AVVRG & & 9.6768 \\
\hline 111)B Benzyl chloride & $|1.4229659|$ & $\left|\begin{array}{l}0.9720164 \\
\mid 1.3021874\end{array}\right|$ & $\begin{array}{l}1.1794445 \\
1.3243194\end{array}$ & $|1.2818045|$ & 1.4539889 & $\mid 1.3953017$ & $|1.2915|$ & AVRG & & 12.0797 \\
\hline & & & & & & & & & & \\
\hline bis (2-Chloroisopropyl)et & $|0.1081278|$ & $\left|\begin{array}{l}0.0895699 \\
0.1006501\end{array}\right|$ & $\begin{array}{l}0.0998845 \\
0.1929267\end{array}$ & $\mid 0.1002305$ & |e.1075399| & $|0.1043964|$ & $|0.1017|$ & |AVRG & & 5.7340 \\
\hline
\end{tabular}

(\#) = Out of Range (\$) = Individual RF Out of Range

AVRG $=$ Average, $\operatorname{LINR}=$ Linear Regression, $1 / x=$ the inverse of concentration, $1 / x^{\wedge} 2=$ the inverse square of concentration 
Continuing Calibration Summary

Instrument ID: VOA2.I

Data File: 101420V2.bl2J302.D

Lab Sample ID W2VM201014-01

Quant Type ISTD
Client SDG: $\quad 528429$

Injection Date: $\quad$ 14-OCT-20 18:09

Init. Cal. Date(s): 13-OCT-20 21:31 - 14-OCT-20 00:5

Method: $\quad$ 101320V2.b\VOA2-8260D-101320.M

Method Update: $\quad$ 15-OCT-20 16:56

\begin{tabular}{|c|c|c|c|c|c|c|c|c|c|}
\hline Compound & $\begin{array}{c}\text { AVERF / } \\
\text { Amount }\end{array}$ & $\begin{array}{c}\mathrm{RF} \\
\mathrm{CCV}\end{array}$ & $\begin{array}{c}\text { Nominal } \\
\mathrm{CCV}\end{array}$ & Min RF & $\begin{array}{c}\mathbf{R F} \\
\mathbf{Q}\end{array}$ & $\begin{array}{c}\text { \%D / } \\
\text { \%Drift }\end{array}$ & Max & $\begin{array}{c}\text { Drift } \\
Q\end{array}$ & $\begin{array}{l}\text { Curve } \\
\text { Type }\end{array}$ \\
\hline S 1,2-Dichloroethane-d4 & 0.1475 & 0.14984 & & .01 & & 1.58644 & 30 & & Averaged \\
\hline SToluene-d8 & 1.2879 & 1.26558 & & .01 & & -1.73305 & 30 & & Averaged \\
\hline SBromofluorobenzene & 0.9253 & 0.92779 & & .01 & & 0.2691 & 30 & & Averaged \\
\hline Chloromethane & 0.5397 & 0.54472 & & .1 & & 0.93015 & 30 & & Averaged \\
\hline Vinyl chloride & 0.4152 & 0.39637 & & .01 & & -4.53516 & 30 & & Averaged \\
\hline 1,1-Dichloroethylene & 0.5541 & 0.56801 & & .01 & & 2.51038 & 30 & & Averaged \\
\hline tert-Butyl methyl ether & 0.8226 & 0.85268 & & .01 & & 3.6567 & 30 & & Averaged \\
\hline 1,1-Dichloroethane & 0.5826 & 0.60269 & & .1 & & 3.44834 & 30 & & Averaged \\
\hline Chloroform & 0.5227 & 0.54046 & & .01 & & 3.39774 & 30 & & Averaged \\
\hline 1,2-Dichloroethane & 0.4326 & 0.41794 & & .01 & & -3.38881 & 30 & & Averaged \\
\hline Benzene & 1.1607 & 1.12799 & & .01 & & -2.81813 & 30 & & Averaged \\
\hline 1,2-Dichloropropane & 0.3344 & 0.329 & & .01 & & -1.61483 & 30 & & Averaged \\
\hline Toluene & 1.6745 & 1.62271 & & .01 & & -3.09286 & 30 & & Averaged \\
\hline 1,2-Dibromoethane & 0.3136 & 0.32977 & & .01 & & 5.15625 & 30 & & Averaged \\
\hline Chlorobenzene & 1.0802 & 1.04098 & & .3 & & -3.63081 & 30 & & Averaged \\
\hline Ethylbenzene & 1.8701 & 1.82445 & & .01 & & -2.44105 & 30 & & Averaged \\
\hline m,p-Xylenes & 0.7089 & 0.68946 & & .01 & & -2.74228 & 30 & & Averaged \\
\hline o-Xylene & 0.7062 & 0.67834 & & .01 & & -3.94506 & 30 & & Averaged \\
\hline Bromoform & 50 & 49.26 & 50 & & & -1.48 & 30 & & Linear \\
\hline 1,1,2,2-Tetrachloroethane & 0.7824 & 0.77114 & & .3 & & -1.43916 & 30 & & Averaged \\
\hline
\end{tabular}

Page 66 of $151 \quad$ SDG: 528429 
Instrument ID: VOA2.I

Data File: $\quad 112720$ V2.b\2P502.D

Lab Sample ID W2VM201127-01

Quant Type ISTD
Client SDG: $\quad 528429$

Injection Date: $\quad$ 27-NOV-20 17:29

Init. Cal. Date(s): $\quad$ 13-OCT-20 21:31 - 14-OCT-20 00:5

Method: $\quad$ 101320V2.b\VOA2-8260D-101320.M

Method Update: $\quad$ 15-OCT-20 16:56

\begin{tabular}{|c|c|c|c|c|c|c|c|c|c|}
\hline Compound & $\begin{array}{c}\text { AVERF / } \\
\text { Amount }\end{array}$ & $\begin{array}{c}\text { RF } \\
\mathrm{CCV}\end{array}$ & $\begin{array}{c}\text { Nominal } \\
\mathrm{CCV}\end{array}$ & Min RF & $\begin{array}{c}\mathbf{R F} \\
\mathbf{Q}\end{array}$ & $\begin{array}{l}\text { \%D / } \\
\% \text { Drift }\end{array}$ & Max & $\begin{array}{c}\text { Drift } \\
\text { Q }\end{array}$ & $\begin{array}{l}\text { Curve } \\
\text { Type }\end{array}$ \\
\hline $\mathrm{S} 1,2$-Dichloroethane-d4 & 0.1475 & 0.14604 & & .01 & & -0.98983 & 20 & & Averaged \\
\hline SToluene-d8 & 1.2879 & 1.22546 & & .01 & & -4.8482 & 20 & & Averaged \\
\hline SBromofluorobenzene & 0.9253 & 0.89661 & & .01 & & -3.10062 & 20 & & Averaged \\
\hline Chloromethane & 0.5397 & 0.50988 & & .1 & & -5.52529 & 20 & & Averaged \\
\hline Vinyl chloride & 0.4152 & 0.38351 & & .01 & & -7.63247 & 20 & & Averaged \\
\hline 1,1-Dichloroethylene & 0.5541 & 0.54554 & & .01 & & -1.54485 & 20 & & Averaged \\
\hline tert-Butyl methyl ether & 0.8226 & 0.83625 & & .01 & & 1.65937 & 20 & & Averaged \\
\hline 1,1-Dichloroethane & 0.5826 & 0.59774 & & .1 & & 2.5987 & 20 & & Averaged \\
\hline Chloroform & 0.5227 & 0.531 & & .01 & & 1.58791 & 20 & & Averaged \\
\hline 1,2-Dichloroethane & 0.4326 & 0.40446 & & .01 & & -6.50485 & 20 & & Averaged \\
\hline Benzene & 1.1607 & 1.09669 & & .01 & & -5.51478 & 20 & & Averaged \\
\hline 1,2-Dichloropropane & 0.3344 & 0.32429 & & .01 & & -3.02333 & 20 & & Averaged \\
\hline Toluene & 1.6745 & 1.53885 & & .01 & & -8.10093 & 20 & & Averaged \\
\hline 1,2-Dibromoethane & 0.3136 & 0.30843 & & .01 & & -1.6486 & 20 & & Averaged \\
\hline Chlorobenzene & 1.0802 & 0.99191 & & .3 & & -8.17349 & 20 & & Averaged \\
\hline Ethylbenzene & 1.8701 & 1.73884 & & .01 & & -7.01888 & 20 & & Averaged \\
\hline m,p-Xylenes & 0.7089 & 0.65922 & & .01 & & -7.00804 & 20 & & Averaged \\
\hline o-Xylene & 0.7062 & 0.65258 & & .01 & & -7.59275 & 20 & & Averaged \\
\hline Bromoform & 50 & 44.72 & 50 & & & -10.56 & 20 & & Linear \\
\hline 1,1,2,2-Tetrachloroethane & 0.7824 & 0.73071 & & .3 & & -6.6066 & 20 & & Averaged \\
\hline
\end{tabular}

Page 67 of $151 \quad$ SDG: 528429 
Continuing Calibration Summary

Instrument ID: VOA2.I

Data File: $\quad 113020$ V2.b\2Q106.D

Lab Sample ID W2VM201130-05

Quant Type ISTD
Client SDG: $\quad 528429$

Injection Date: $\quad 30-N O V-2020: 54$

Init. Cal. Date(s): $\quad$ 13-OCT-20 21:31 - 14-OCT-20 00:5

Method: $\quad$ 101320V2.b\VOA2-8260D-101320.M

Method Update: $\quad$ 15-OCT-20 16:56

\begin{tabular}{|c|c|c|c|c|c|c|c|c|c|}
\hline Compound & $\begin{array}{c}\text { AVERF / } \\
\text { Amount }\end{array}$ & $\begin{array}{c}\mathrm{RF} \\
\mathrm{CCV}\end{array}$ & $\begin{array}{c}\text { Nominal } \\
\mathrm{CCV}\end{array}$ & Min RF & $\begin{array}{c}\text { RF } \\
\text { Q }\end{array}$ & $\begin{array}{l}\text { \%D / } \\
\text { \%Drift }\end{array}$ & Max & $\begin{array}{c}\text { Drift } \\
\text { Q }\end{array}$ & $\begin{array}{l}\text { Curve } \\
\text { Type }\end{array}$ \\
\hline S1,2-Dichloroethane-d4 & 0.1475 & 0.14435 & & .01 & & -2.13559 & 20 & & Averaged \\
\hline SToluene-d8 & 1.2879 & 1.28711 & & .01 & & -0.06134 & 20 & & Averaged \\
\hline SBromofluorobenzene & 0.9253 & 0.88753 & & .01 & & -4.08192 & 20 & & Averaged \\
\hline Chloromethane & 0.5397 & 0.55971 & & .1 & & 3.70762 & 20 & & Averaged \\
\hline Vinyl chloride & 0.4152 & 0.4354 & & .01 & & 4.86513 & 20 & & Averaged \\
\hline 1,1-Dichloroethylene & 0.5541 & 0.45163 & & .01 & & -18.49305 & 20 & & Averaged \\
\hline tert-Butyl methyl ether & 0.8226 & 0.77705 & & .01 & & -5.53732 & 20 & & Averaged \\
\hline 1,1-Dichloroethane & 0.5826 & 0.54706 & & .1 & & -6.10024 & 20 & & Averaged \\
\hline Chloroform & 0.5227 & 0.49729 & & .01 & & -4.8613 & 20 & & Averaged \\
\hline 1,2-Dichloroethane & 0.4326 & 0.36673 & & .01 & & -15.22654 & 20 & & Averaged \\
\hline Benzene & 1.1607 & 1.03574 & & .01 & & -10.76592 & 20 & & Averaged \\
\hline 1,2-Dichloropropane & 0.3344 & 0.30452 & & .01 & & -8.93541 & 20 & & Averaged \\
\hline Toluene & 1.6745 & 1.56349 & & .01 & & -6.62944 & 20 & & Averaged \\
\hline 1,2-Dibromoethane & 0.3136 & 0.30822 & & .01 & & -1.71556 & 20 & & Averaged \\
\hline Chlorobenzene & 1.0802 & 1.01823 & & .3 & & -5.7369 & 20 & & Averaged \\
\hline Ethylbenzene & 1.8701 & 1.77459 & & .01 & & -5.10721 & 20 & & Averaged \\
\hline m,p-Xylenes & 0.7089 & 0.67804 & & .01 & & -4.35322 & 20 & & Averaged \\
\hline o-Xylene & 0.7062 & 0.67591 & & .01 & & -4.28915 & 20 & & Averaged \\
\hline Bromoform & 50 & 46.59 & 50 & & & -6.82 & 20 & & Linear \\
\hline 1,1,2,2-Tetrachloroethane & 0.7824 & 0.73083 & & .3 & & -6.59126 & 20 & & Averaged \\
\hline
\end{tabular}

Page 68 of $151 \quad$ SDG: 528429 
Continuing Calibration Summary

Instrument ID: VOA3.I

Data File: $\quad 112520 \mathrm{~V} 3 \backslash 3 \mathrm{X} 312$.D

Lab Sample ID W3VM201125-10

Quant Type ISTD
Client SDG: $\quad 528429$

Injection Date: $\quad$ 25-NOV-20 21:50

Init. Cal. Date(s): $\quad$ 25-NOV-20 17:22 - 25-NOV-20 20:5

Method: $\quad$ 112520V3\VOA3-8260D-112520.M

Method Update: $\quad$ 27-NOV-20 17:58

\begin{tabular}{|c|c|c|c|c|c|c|c|c|c|}
\hline Compound & $\begin{array}{c}\text { AVERF / } \\
\text { Amount }\end{array}$ & $\begin{array}{c}\text { RF } \\
\mathrm{CCV}\end{array}$ & $\begin{array}{c}\text { Nominal } \\
\mathrm{CCV}\end{array}$ & Min RF & $\begin{array}{c}\mathbf{R F} \\
\mathbf{Q}\end{array}$ & $\begin{array}{c}\text { \%D / } \\
\text { \%Drift }\end{array}$ & Max & $\begin{array}{c}\text { Drift } \\
\text { Q }\end{array}$ & $\begin{array}{l}\text { Curve } \\
\text { Type }\end{array}$ \\
\hline S 1,2-Dichloroethane-d4 & 0.2242 & 0.22394 & & .01 & & -0.11597 & 30 & & Averaged \\
\hline SToluene-d8 & 2.4963 & 2.50263 & & .01 & & 0.25358 & 30 & & Averaged \\
\hline SBromofluorobenzene & 0.9808 & 0.97756 & & .01 & & -0.33034 & 30 & & Averaged \\
\hline Chloromethane & 0.4219 & 0.36933 & & .1 & & -12.4603 & 30 & & Averaged \\
\hline Vinyl chloride & 0.3449 & 0.30671 & & .01 & & -11.07277 & 30 & & Averaged \\
\hline tert-Butyl methyl ether & 0.9055 & 1.01052 & & .01 & & 11.59801 & 30 & & Averaged \\
\hline 1,1-Dichloroethylene & 0.4114 & 0.46533 & & .01 & & 13.1089 & 30 & & Averaged \\
\hline 1,1-Dichloroethane & 0.557 & 0.62054 & & .1 & & 11.40754 & 30 & & Averaged \\
\hline Chloroform & 0.5433 & 0.58581 & & .01 & & 7.82441 & 30 & & Averaged \\
\hline 1,2-Dichloroethane & 0.5154 & 0.5129 & & .01 & & -0.48506 & 30 & & Averaged \\
\hline Benzene & 1.1574 & 1.2395 & & .01 & & 7.09349 & 30 & & Averaged \\
\hline 1,2-Dichloropropane & 0.369 & 0.39643 & & .01 & & 7.4336 & 30 & & Averaged \\
\hline Toluene & 2.4827 & 2.57974 & & .01 & & 3.90865 & 30 & & Averaged \\
\hline 1,2-Dibromoethane & 0.5438 & 0.60622 & & .01 & & 11.47848 & 30 & & Averaged \\
\hline Chlorobenzene & 1.6274 & 1.65826 & & .3 & & 1.89628 & 30 & & Averaged \\
\hline Ethylbenzene & 2.8458 & 2.90847 & & .01 & & 2.20219 & 30 & & Averaged \\
\hline m,p-Xylenes & 1.0472 & 1.0817 & & .01 & & 3.2945 & 30 & & Averaged \\
\hline o-Xylene & 1.0429 & 1.0679 & & .01 & & 2.39716 & 30 & & Averaged \\
\hline Bromoform & 50 & 52.83 & 50 & & & 5.66 & 30 & & Linear \\
\hline 1,1,2,2-Tetrachloroethane & 0.7502 & 0.81077 & & .3 & & 8.07385 & 30 & & Averaged \\
\hline
\end{tabular}

Page 69 of 151 SDG: 528429 
Continuing Calibration Summary

Instrument ID: VOA3.I

Data File: $\quad 112720$ V3 $\backslash 3 \times 503 . D$

Lab Sample ID W3VM201127-02

Quant Type ISTD
Client SDG: $\quad 528429$

Injection Date: $\quad$ 27-NOV-20 18:45

Init. Cal. Date(s): $\quad$ 25-NOV-20 17:22 - 25-NOV-20 20:5

Method: $\quad$ 112520V3\VOA3-8260D-112520.M

Method Update: $\quad$ 27-NOV-20 17:58

\begin{tabular}{|c|c|c|c|c|c|c|c|c|c|}
\hline Compound & $\begin{array}{c}\text { AVERF / } \\
\text { Amount }\end{array}$ & $\begin{array}{c}\text { RF } \\
\mathrm{CCV}\end{array}$ & $\begin{array}{c}\text { Nominal } \\
\mathrm{CCV}\end{array}$ & Min RF & $\begin{array}{c}\mathbf{R F} \\
\mathbf{Q}\end{array}$ & $\begin{array}{l}\text { \%D / } \\
\% \text { Drift }\end{array}$ & Max & $\begin{array}{c}\text { Drift } \\
\text { Q }\end{array}$ & $\begin{array}{l}\text { Curve } \\
\text { Type }\end{array}$ \\
\hline $\mathrm{S} 1,2$-Dichloroethane-d4 & 0.2242 & 0.229 & & .01 & & 2.14095 & 20 & & Averaged \\
\hline SToluene-d8 & 2.4963 & 2.50949 & & .01 & & 0.52838 & 20 & & Averaged \\
\hline SBromofluorobenzene & 0.9808 & 0.97402 & & .01 & & -0.69127 & 20 & & Averaged \\
\hline Chloromethane & 0.4219 & 0.36583 & & .1 & & -13.28988 & 20 & & Averaged \\
\hline Vinyl chloride & 0.3449 & 0.31256 & & .01 & & -9.37663 & 20 & & Averaged \\
\hline tert-Butyl methyl ether & 0.9055 & 0.89021 & & .01 & & -1.68857 & 20 & & Averaged \\
\hline 1,1-Dichloroethylene & 0.4114 & 0.4353 & & .01 & & 5.80943 & 20 & & Averaged \\
\hline 1,1-Dichloroethane & 0.557 & 0.58152 & & .1 & & 4.40215 & 20 & & Averaged \\
\hline Chloroform & 0.5433 & 0.54619 & & .01 & & 0.53193 & 20 & & Averaged \\
\hline 1,2-Dichloroethane & 0.5154 & 0.45947 & & .01 & & -10.85177 & 20 & & Averaged \\
\hline Benzene & 1.1574 & 1.14086 & & .01 & & -1.42907 & 20 & & Averaged \\
\hline 1,2-Dichloropropane & 0.369 & 0.35821 & & .01 & & -2.92412 & 20 & & Averaged \\
\hline Toluene & 2.4827 & 2.35156 & & .01 & & -5.28215 & 20 & & Averaged \\
\hline 1,2-Dibromoethane & 0.5438 & 0.52774 & & .01 & & -2.95329 & 20 & & Averaged \\
\hline Chlorobenzene & 1.6274 & 1.50718 & & .3 & & -7.38724 & 20 & & Averaged \\
\hline Ethylbenzene & 2.8458 & 2.7021 & & .01 & & -5.04955 & 20 & & Averaged \\
\hline m,p-Xylenes & 1.0472 & 1.00679 & & .01 & & -3.85886 & 20 & & Averaged \\
\hline o-Xylene & 1.0429 & 0.98804 & & .01 & & -5.26033 & 20 & & Averaged \\
\hline Bromoform & 50 & 46.99 & 50 & & & -6.02 & 20 & & Linear \\
\hline 1,1,2,2-Tetrachloroethane & 0.7502 & 0.69194 & & .3 & & -7.76593 & 20 & & Averaged \\
\hline
\end{tabular}

Page 70 of $151 \quad$ SDG: 528429 


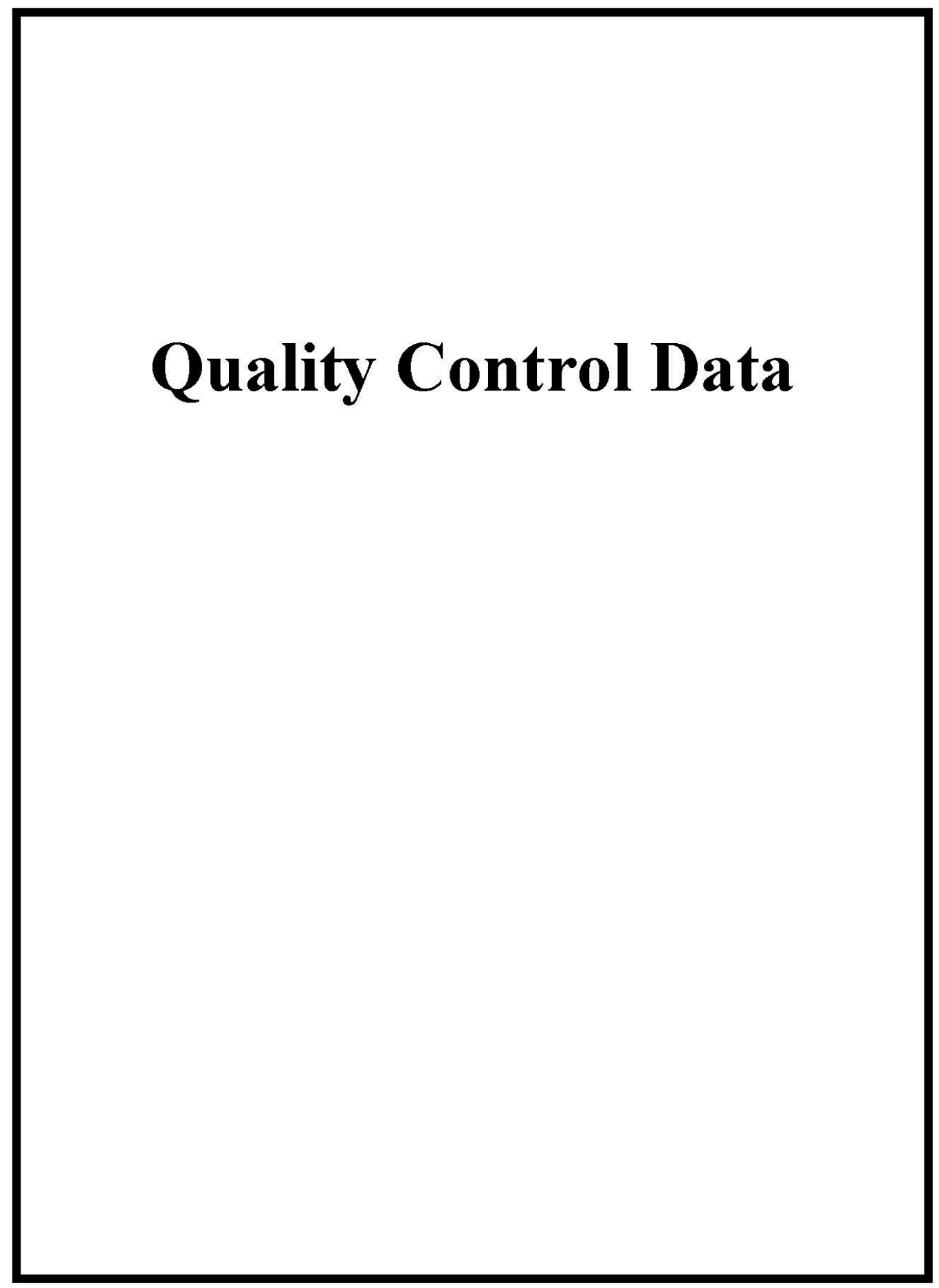

Page 71 of 151 SDG: 528429 


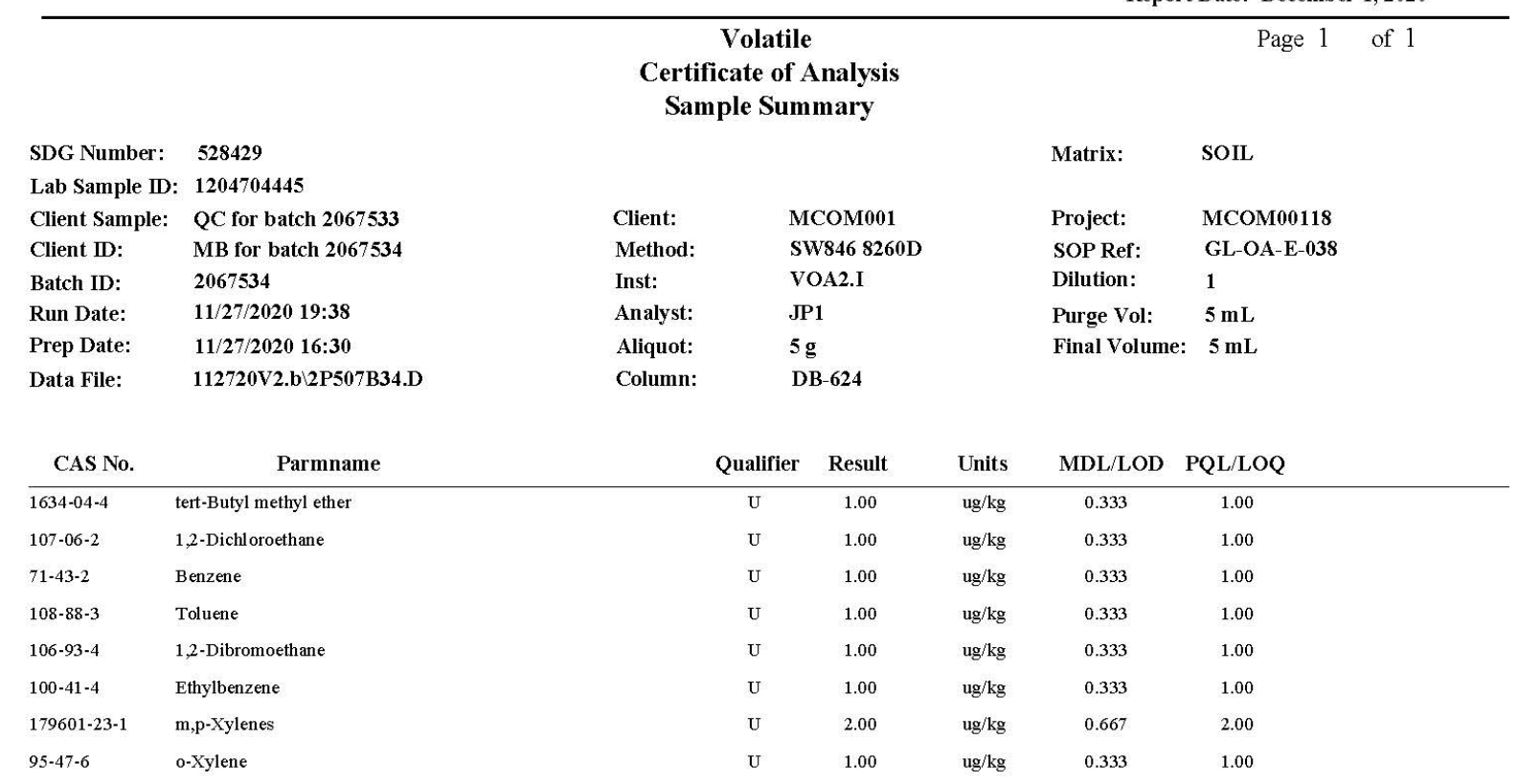

Page 72 of 151 SDG: 528429 


\begin{tabular}{|c|c|c|c|c|c|c|c|}
\hline \multicolumn{8}{|c|}{$\begin{array}{c}\text { Volatile } \\
\text { Certificate of Analysis } \\
\text { Sample Summary }\end{array}$} \\
\hline \multirow{2}{*}{\multicolumn{8}{|c|}{$\begin{array}{ll}\text { SDG Number: } & 528429 \\
\text { Lab Sample ID: } & \mathbf{1 2 0 4 7 0 4 4 4 6}\end{array}$}} \\
\hline & & & & & & & \\
\hline \multirow{6}{*}{$\begin{array}{l}\text { Client Sample: } \\
\text { Client ID: } \\
\text { Batch ID: } \\
\text { Run Date: } \\
\text { Prep Date: } \\
\text { Data File: }\end{array}$} & QC for batch 2067533 & Client: & \multicolumn{3}{|c|}{ MCOM001 } & Project: & MCOM00118 \\
\hline & MB for batch 2067534 & Method: & \multicolumn{3}{|c|}{ SW846 8260D } & SOP Ref: & GL-OA-E-038 \\
\hline & 2067534 & Inst: & \multicolumn{3}{|c|}{ VOA2.I } & Dilution: & 1 \\
\hline & $11 / 30 / 202022: 38$ & Analyst: & \multicolumn{3}{|c|}{ JP1 } & Purge Vol: & $5 \mathrm{~mL}$ \\
\hline & $11 / 30 / 2020$ 18:30 & Aliquot: & \multicolumn{3}{|c|}{$5 \mathrm{~g}$} & Final Volume: & $5 \mathrm{~mL}$ \\
\hline & $113020 \mathrm{~V} 2 . \mathrm{b} \backslash 2 \mathrm{Q} 110 \mathrm{~B} 34 . \mathrm{D}$ & Column: & \multicolumn{3}{|c|}{ DB-624 } & & \\
\hline CAS No. & Parmname & & Qualifier & Result & Units & MDL/LOD & PQL/LOQ \\
\hline $1634-04-4$ & tert-Butyl methyl ether & & $\mathrm{U}$ & 1.00 & $\mathrm{ug} / \mathrm{kg}$ & 0.333 & 1.00 \\
\hline $107-06-2$ & 1,2-Dichloroethane & & $\mathrm{U}$ & 1.00 & $\mathrm{ug} / \mathrm{kg}$ & 0.333 & 1.00 \\
\hline $71-43-2$ & Benzene & & $\mathrm{U}$ & 1.00 & $\mathrm{ug} / \mathrm{kg}$ & 0.333 & 1.00 \\
\hline 108-88-3 & Toluene & & $\mathrm{U}$ & 1.00 & $\mathrm{ug} / \mathrm{kg}$ & 0.333 & 1.00 \\
\hline $106-93-4$ & 1,2-Dibromoethane & & $\mathrm{U}$ & 1.00 & $\mathrm{ug} / \mathrm{kg}$ & 0.333 & 1.00 \\
\hline $100-41-4$ & Ethylbenzene & & U & 1.00 & $\mathrm{ug} / \mathrm{kg}$ & 0.333 & 1.00 \\
\hline 179601-23-1 & m,p-Xylenes & & $\mathrm{U}$ & 2.00 & $\mathrm{ug} / \mathrm{kg}$ & 0.667 & 2.00 \\
\hline $95-47-6$ & o-Xylene & & $\mathrm{U}$ & 1.00 & $\mathrm{ug} / \mathrm{kg}$ & 0.333 & 1.00 \\
\hline
\end{tabular}

Page 73 of 151 SDG: 528429 


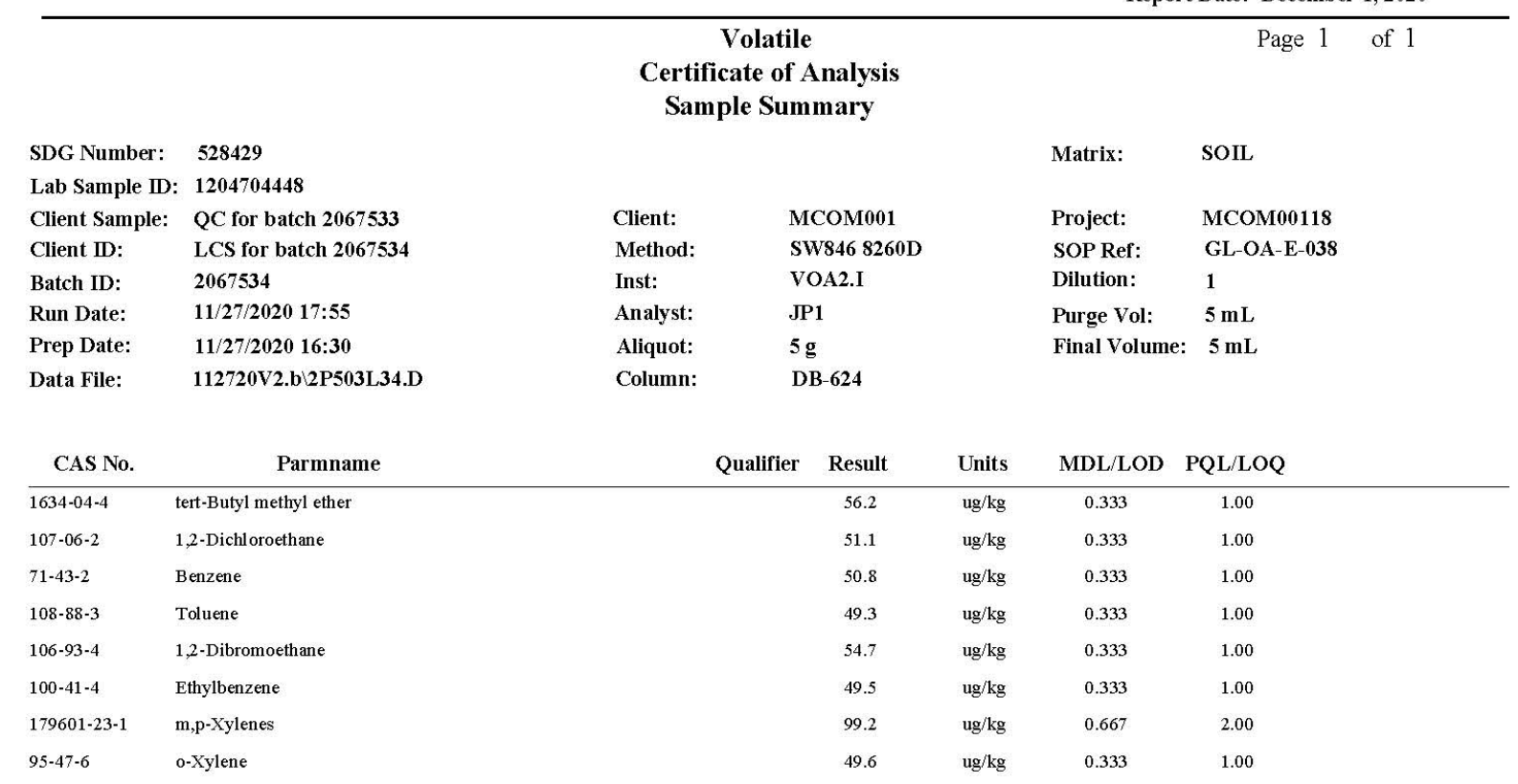




\begin{tabular}{|c|c|c|c|c|c|c|c|}
\hline \multicolumn{8}{|c|}{$\begin{array}{c}\text { Volatile } \\
\text { Certificate of Analysis } \\
\text { Sample Summary }\end{array}$} \\
\hline \multirow{2}{*}{\multicolumn{8}{|c|}{$\begin{array}{ll}\text { SDG Number: } & 528429 \\
\text { Lab Sample ID: } & 1204704449\end{array}$}} \\
\hline & & & & & & & \\
\hline Client Sample: & QC for batch 2067533 & Client: & \multicolumn{3}{|c|}{ MCOM001 } & Project: & MCOM00118 \\
\hline Client ID: & LCS for batch 2067534 & Method: & \multicolumn{2}{|c|}{ SW846 8260D } & & SOP Ref: & GL-OA-E-038 \\
\hline Batch ID: & 2067534 & Inst: & \multicolumn{2}{|c|}{ VOA2.I } & & Dilution: & 1 \\
\hline Run Date: & $11 / 30 / 202021: 20$ & Analyst: & \multicolumn{2}{|c|}{ JP1 } & & \multirow{2}{*}{$\begin{array}{l}\text { Purge Vol: } \\
\text { Final Volume: }\end{array}$} & $5 \mathrm{~mL}$ \\
\hline Prep Date: & $11 / 30 / 202018: 30$ & Aliquot: & \multicolumn{2}{|c|}{$5 \mathrm{~g}$} & & & $5 \mathrm{~mL}$ \\
\hline Data File: & $113020 \mathrm{~V} 2 . \mathrm{b} \backslash 2 \mathrm{Q} 107 \mathrm{~L} 34 . \mathrm{D}$ & Column: & \multicolumn{3}{|c|}{ DB-624 } & & \\
\hline CAS No. & Parmname & & & Result & Units & $\mathrm{MDL} / \mathrm{LOD}$ & PQL/LOQ \\
\hline $1634-04-4$ & tert-Butyl methyl ether & & & 47.6 & $\mathrm{ug} / \mathrm{kg}$ & 0.333 & 1.00 \\
\hline $107-06-2$ & 1,2-Dichloroethane & & & 41.8 & $\mathrm{ug} / \mathrm{kg}$ & 0.333 & 1.00 \\
\hline $71-43-2$ & Benzene & & & 42.7 & $\mathrm{ug} / \mathrm{kg}$ & 0.333 & 1.00 \\
\hline 108-88-3 & Toluene & & & 44.9 & $\mathrm{ug} / \mathrm{kg}$ & 0.333 & 1.00 \\
\hline $106-93-4$ & 1,2-Dibromoethane & & & 49.6 & $\mathrm{ug} / \mathrm{kg}$ & 0.333 & 1.00 \\
\hline $100-41-4$ & Ethylbenzene & & & 45.3 & $\mathrm{ug} / \mathrm{kg}$ & 0.333 & 1.00 \\
\hline 179601-23-1 & m,p-Xylenes & & & 91.4 & $\mathrm{ug} / \mathrm{kg}$ & 0.667 & 2.00 \\
\hline $95-47-6$ & o-Xylene & & & 45.7 & $\mathrm{ug} / \mathrm{kg}$ & 0.333 & 1.00 \\
\hline
\end{tabular}

Page 75 of 151 SDG: 528429 


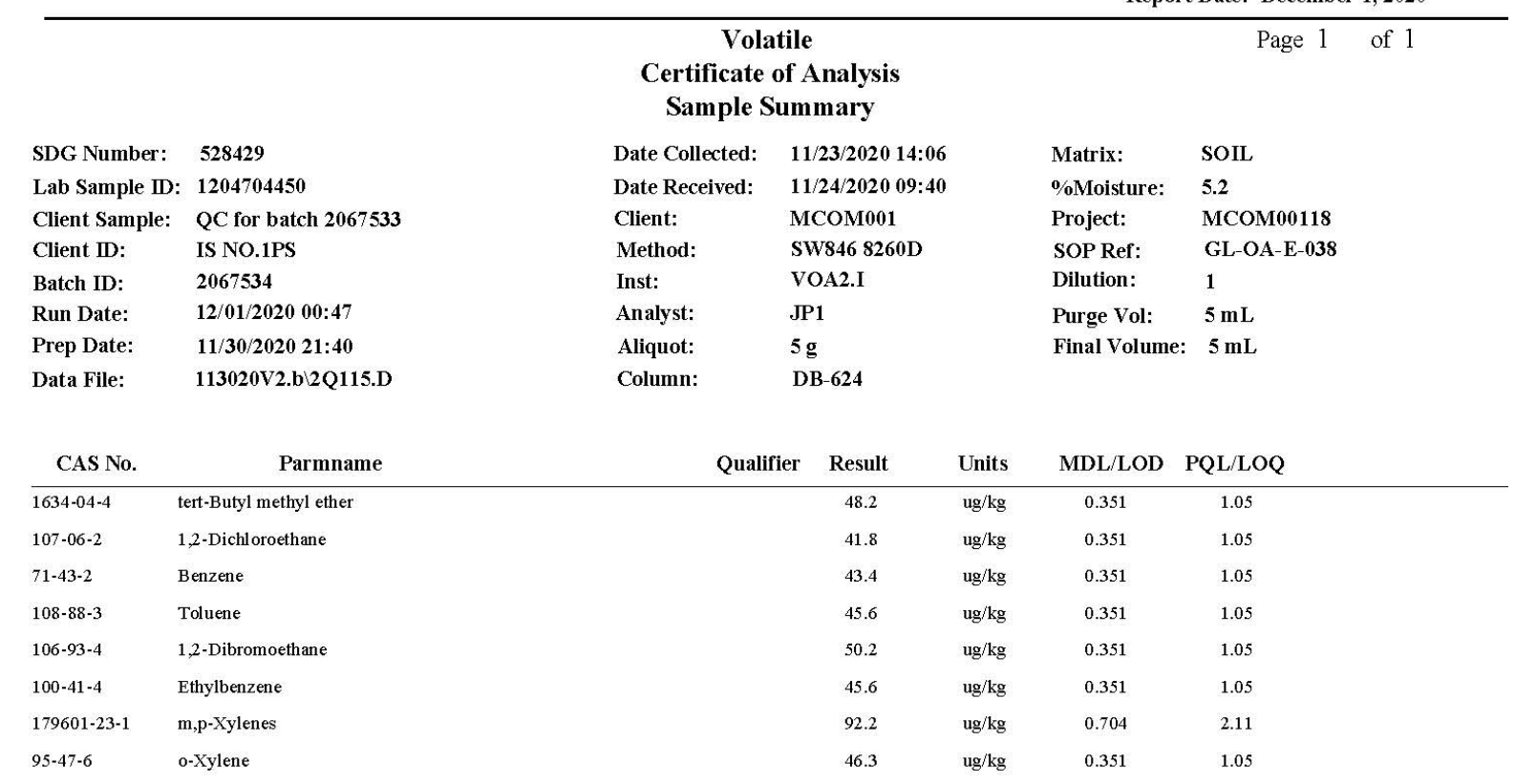




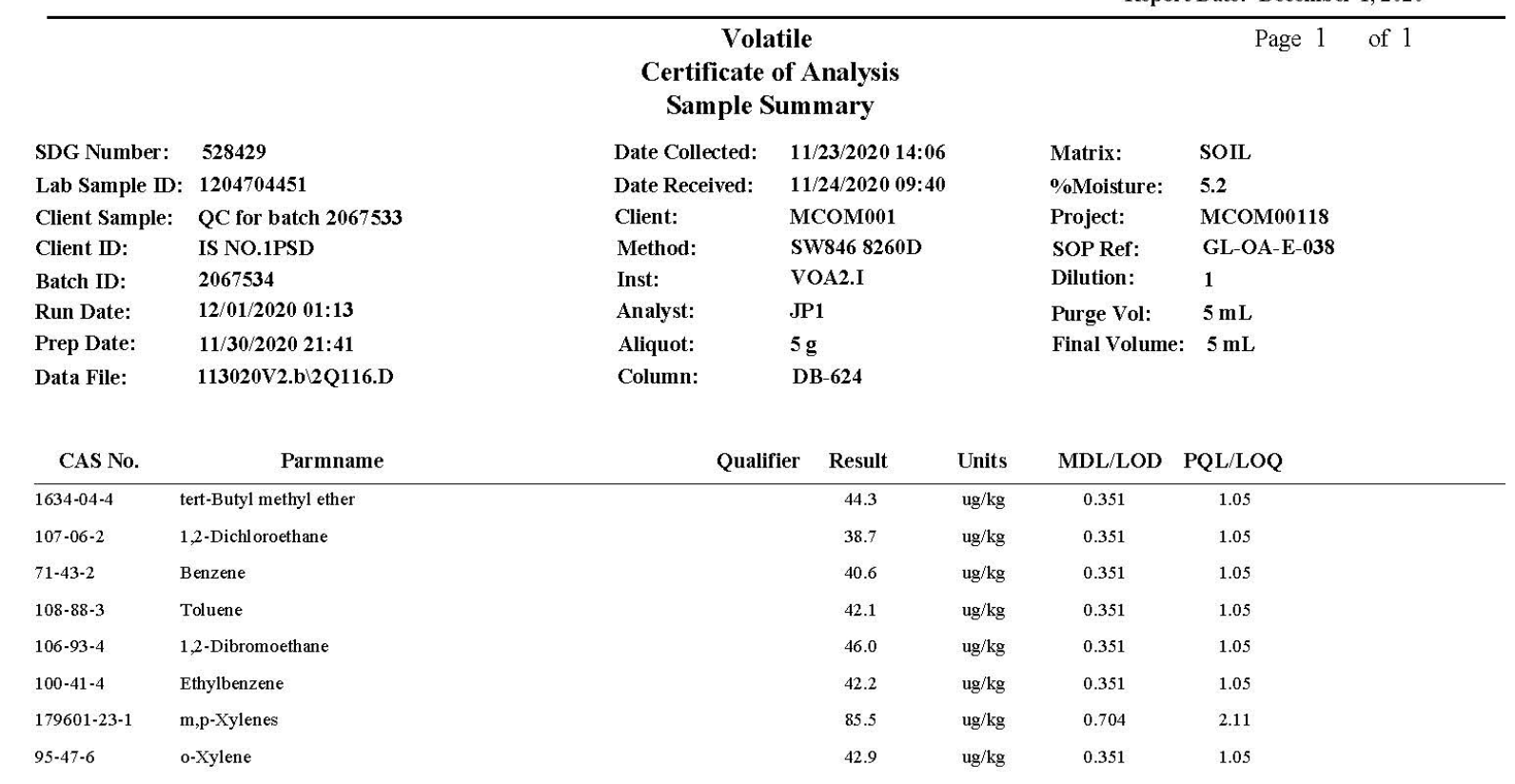




\begin{tabular}{|c|c|c|c|c|c|c|c|}
\hline \multicolumn{8}{|c|}{$\begin{array}{c}\text { Volatile } \\
\text { Certificate of Analysis } \\
\text { Sample Summary }\end{array}$} \\
\hline \multirow{2}{*}{\multicolumn{8}{|c|}{$\begin{array}{ll}\text { SDG Number: } & 528429 \\
\text { Lab Sample ID: } & 1204704452\end{array}$}} \\
\hline & & & & & & & \\
\hline \multirow{6}{*}{$\begin{array}{l}\text { Client Sample: } \\
\text { Client ID: } \\
\text { Batch ID: } \\
\text { Run Date: } \\
\text { Prep Date: } \\
\text { Data File: }\end{array}$} & QC for batch 2067535 & Client: & \multicolumn{3}{|c|}{ MCOM001 } & Project: & МСОМ00118 \\
\hline & MB for batch 2067535 & Method: & \multicolumn{3}{|c|}{ SW846 8260D } & SOP Ref: & GL-OA-E-038 \\
\hline & 2067535 & Inst: & \multicolumn{3}{|c|}{ VOA3.I } & Dilution: & 1 \\
\hline & $11 / 27 / 202020: 05$ & Analyst: & \multicolumn{3}{|c|}{ JP1 } & Purge Vol: & $5 \mathrm{~mL}$ \\
\hline & $11 / 27 / 202020: 05$ & & & & & & \\
\hline & $112720 \mathrm{~V} 3 \backslash 3 \mathrm{X} 506 \mathrm{~B} 35 . \mathrm{D}$ & Column: & \multicolumn{3}{|c|}{ DB-624 } & & \\
\hline CAS No. & Parmname & & Qualifier & Result & Units & MDL/LOD & PQL/LOQ \\
\hline $1634-04-4$ & tert-Butyl methyl ether & & $\mathrm{U}$ & 1.00 & $\mathrm{ug} / \mathrm{L}$ & 0.333 & 1.00 \\
\hline $107-06-2$ & 1,2-Dichloroethane & & U & 1.00 & $\mathrm{ug} / \mathrm{L}$ & 0.333 & 1.00 \\
\hline $71-43-2$ & Benzene & & $\mathrm{U}$ & 1.00 & $\mathrm{ug} / \mathrm{L}$ & 0.333 & 1.00 \\
\hline $108-88-3$ & Toluene & & $\mathrm{U}$ & 1.00 & $\mathrm{ug} / \mathrm{L}$ & 0.333 & 1.00 \\
\hline $106-93-4$ & 1,2-Dibromoethane & & $\mathrm{U}$ & 1.00 & $\mathrm{ug} / \mathrm{L}$ & 0.333 & 1.00 \\
\hline $100-41-4$ & Ethylbenzene & & $\mathrm{U}$ & 1.00 & $\mathrm{ug} / \mathrm{L}$ & 0.333 & 1.00 \\
\hline $179601-23-1$ & $\mathrm{~m}, \mathrm{p}$-Xylenes & & U & 2.00 & $\mathrm{ug} / \mathrm{L}$ & 0.667 & 2.00 \\
\hline $95-47-6$ & o-Xylene & & $\mathrm{U}$ & 1.00 & $\mathrm{ug} / \mathrm{L}$ & 0.333 & 1.00 \\
\hline
\end{tabular}

Page 78 of 151 SDG: 528429 


\begin{tabular}{|c|c|c|c|c|c|c|c|}
\hline \multicolumn{8}{|c|}{$\begin{array}{c}\text { Volatile } \\
\text { Certificate of Analysis } \\
\text { Sample Summary }\end{array}$} \\
\hline \multirow{2}{*}{\multicolumn{8}{|c|}{$\begin{array}{ll}\text { SDG Number: } & 528429 \\
\text { Lab Sample ID: } & 1204704454\end{array}$}} \\
\hline & & & & & & & \\
\hline \multirow{5}{*}{$\begin{array}{l}\text { Client Sample: } \\
\text { Client ID: } \\
\text { Batch ID: } \\
\text { Run Date: } \\
\text { Prep Date: }\end{array}$} & QC for batch 2067535 & Client: & \multicolumn{3}{|c|}{ MCOM001 } & Project: & MCOM00118 \\
\hline & LCS for batch 2067535 & Method: & \multicolumn{3}{|c|}{ SW846 8260D } & SOP Ref: & GL-OA-E-038 \\
\hline & 2067535 & Inst: & \multicolumn{3}{|c|}{ VOA3.I } & Dilution: & 1 \\
\hline & $11 / 27 / 202018: 45$ & Analyst: & \multicolumn{3}{|c|}{ JP1 } & Purge Vol: & $5 \mathrm{~mL}$ \\
\hline & $11 / 27 / 202018: 45$ & & & & & & \\
\hline Data File: & $112720 \mathrm{~V} 3 \backslash 3 \times 503 \mathrm{~L} 35 . \mathrm{D}$ & Column: & \multicolumn{3}{|c|}{ DB-624 } & & \\
\hline CAS No. & Parmname & & Qualifier & Result & Units & $\mathrm{MDL} / \mathrm{LOD}$ & PQL/LOQ \\
\hline $1634-04-4$ & tert-Butyl methyl ether & & & 49.2 & $\mathrm{ug} / \mathrm{L}$ & 0.333 & 1.00 \\
\hline $107-06-2$ & 1,2-Dichloroethane & & & 44.6 & $\mathrm{ug} / \mathrm{L}$ & 0.333 & 1.00 \\
\hline $71-43-2$ & Benzene & & & 49.3 & $\mathrm{ug} / \mathrm{L}$ & 0.333 & 1.00 \\
\hline 108-88-3 & Toluene & & & 47.4 & $\mathrm{ug} / \mathrm{L}$ & 0.333 & 1.00 \\
\hline $106-93-4$ & 1,2-Dibromoethane & & & 48.5 & $\mathrm{ug} / \mathrm{L}$ & 0.333 & 1.00 \\
\hline $100-41-4$ & Ethylbenzene & & & 47.5 & $\mathrm{ug} / \mathrm{L}$ & 0.333 & 1.00 \\
\hline 179601-23-1 & $\mathrm{m}, \mathrm{p}$-Xylenes & & & 96.1 & $\mathrm{ug} / \mathrm{L}$ & 0.667 & 2.00 \\
\hline $95-47-6$ & o-Xylene & & & 47.4 & $\mathrm{ug} / \mathrm{L}$ & 0.333 & 1.00 \\
\hline
\end{tabular}

Page 79 of 151 SDG: 528429 


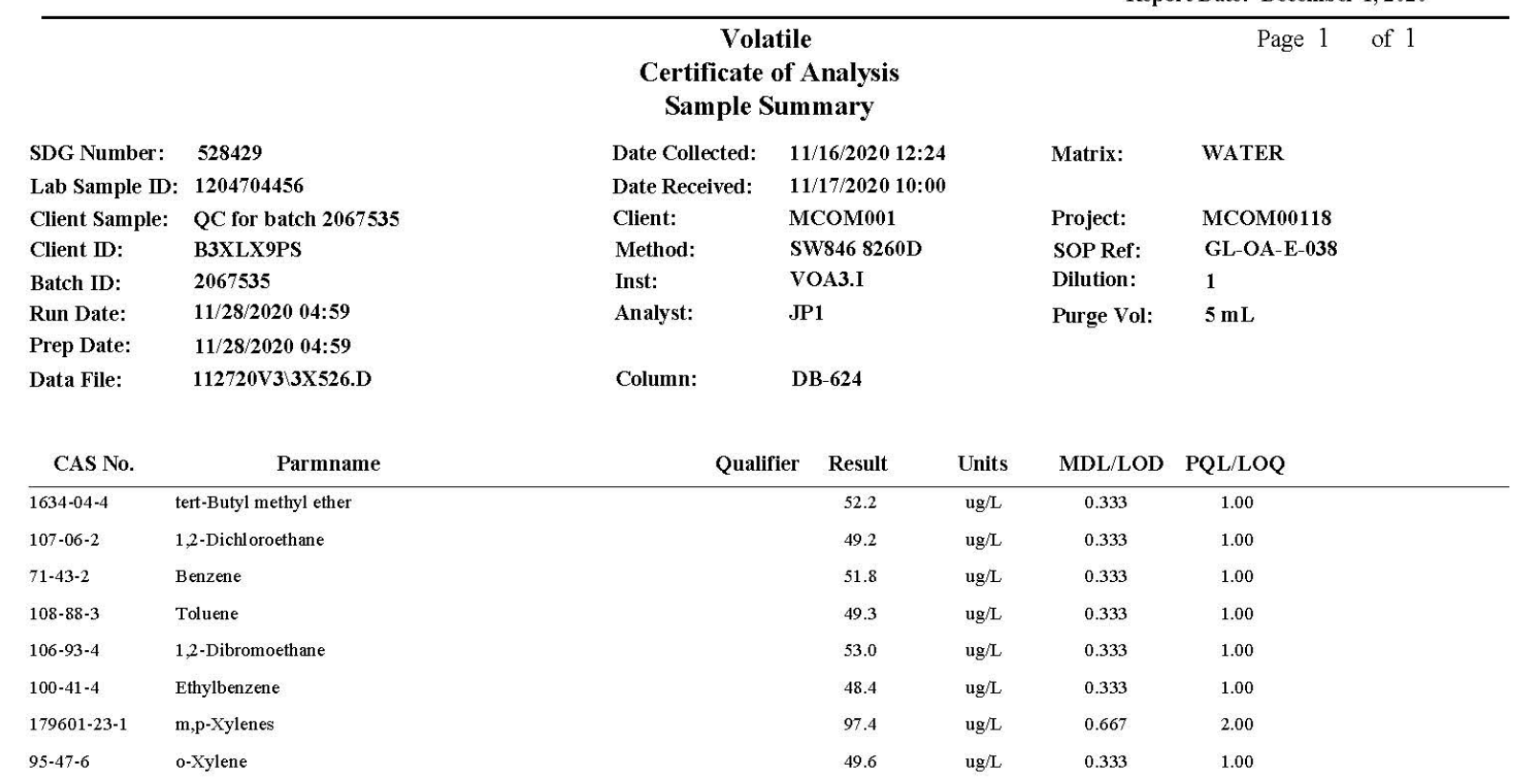

Page 80 of 151 SDG: 528429 


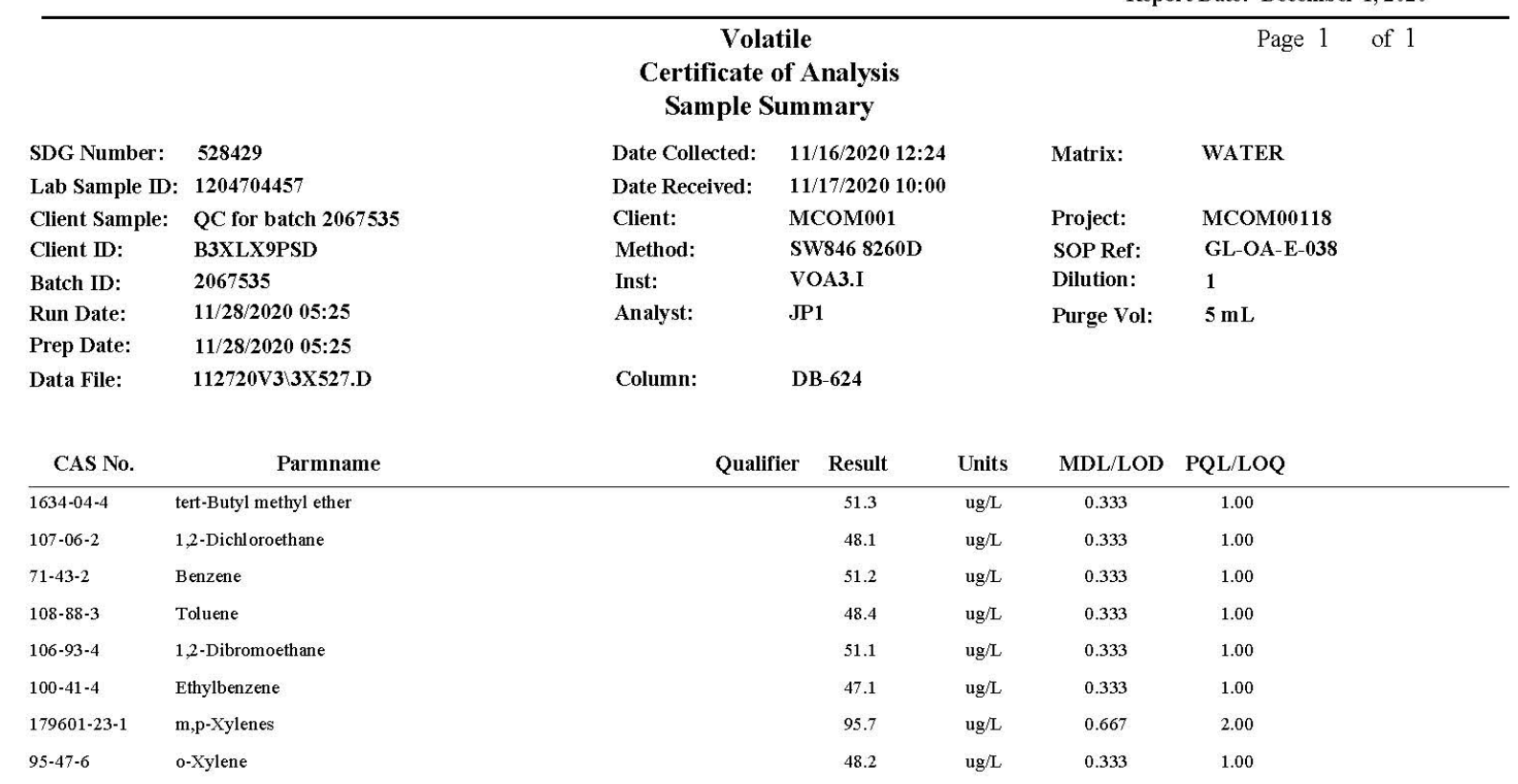

Page 81 of 151 SDG: 528429 


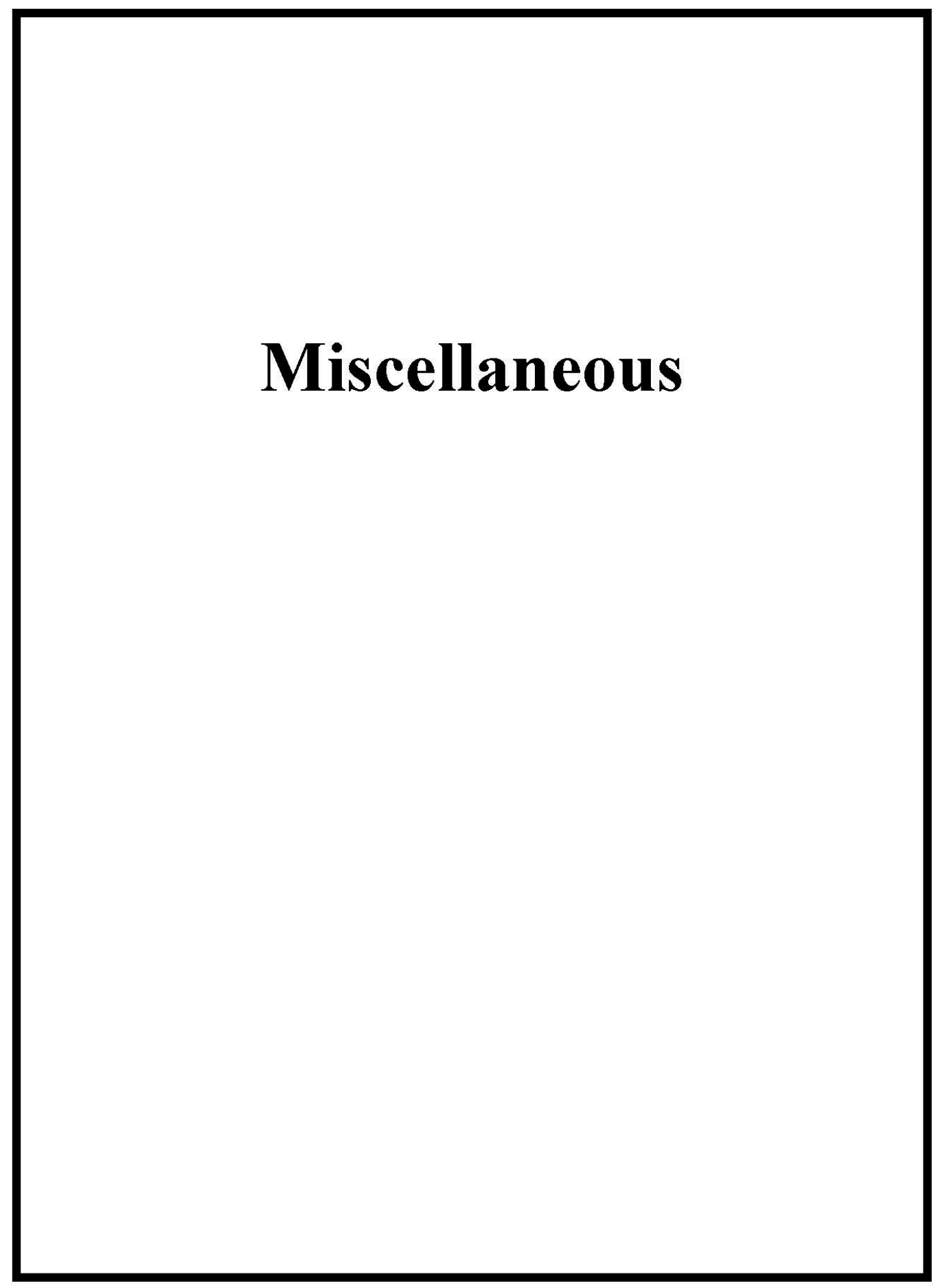

Page 82 of 151 SDG: 528429 
Prep Logbook

Closed-System Purge-and-Trap Collection and Extraction: Volatile Organics in Soil and Waste Samples

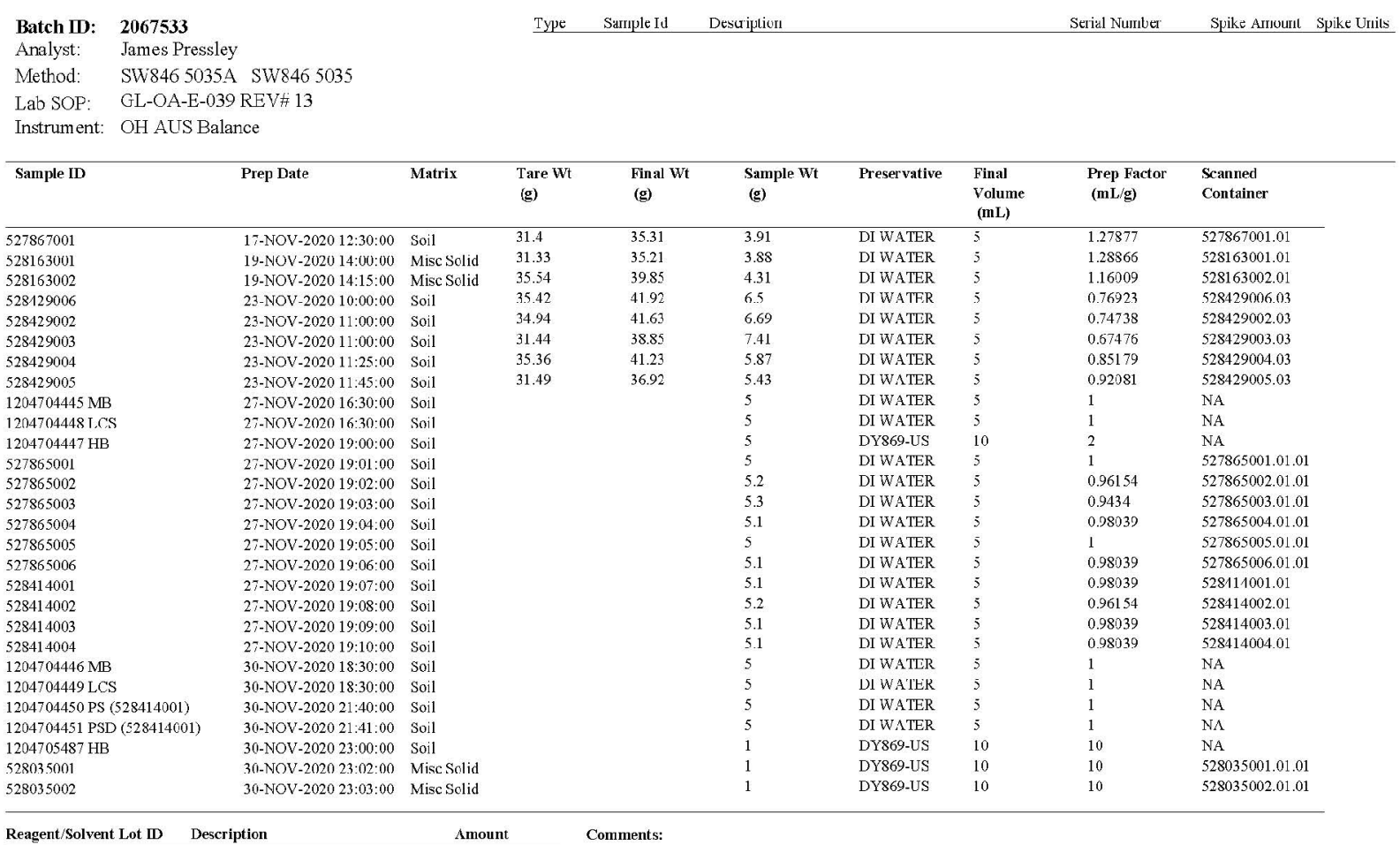

Analytical Logbook version 1 11-04-2002

GEL Laboratories LLC

Page 83 of 151 SDG: 528429 


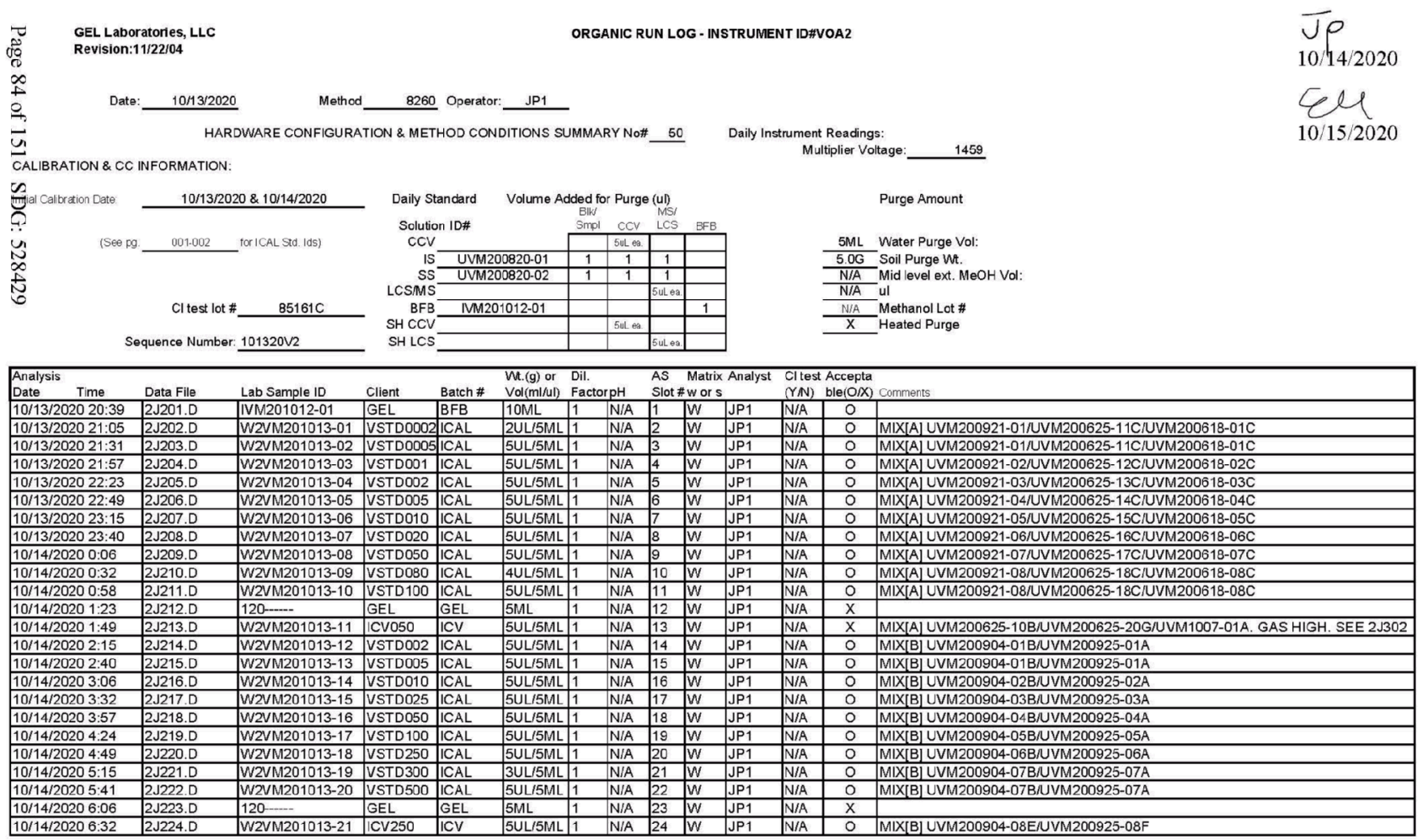




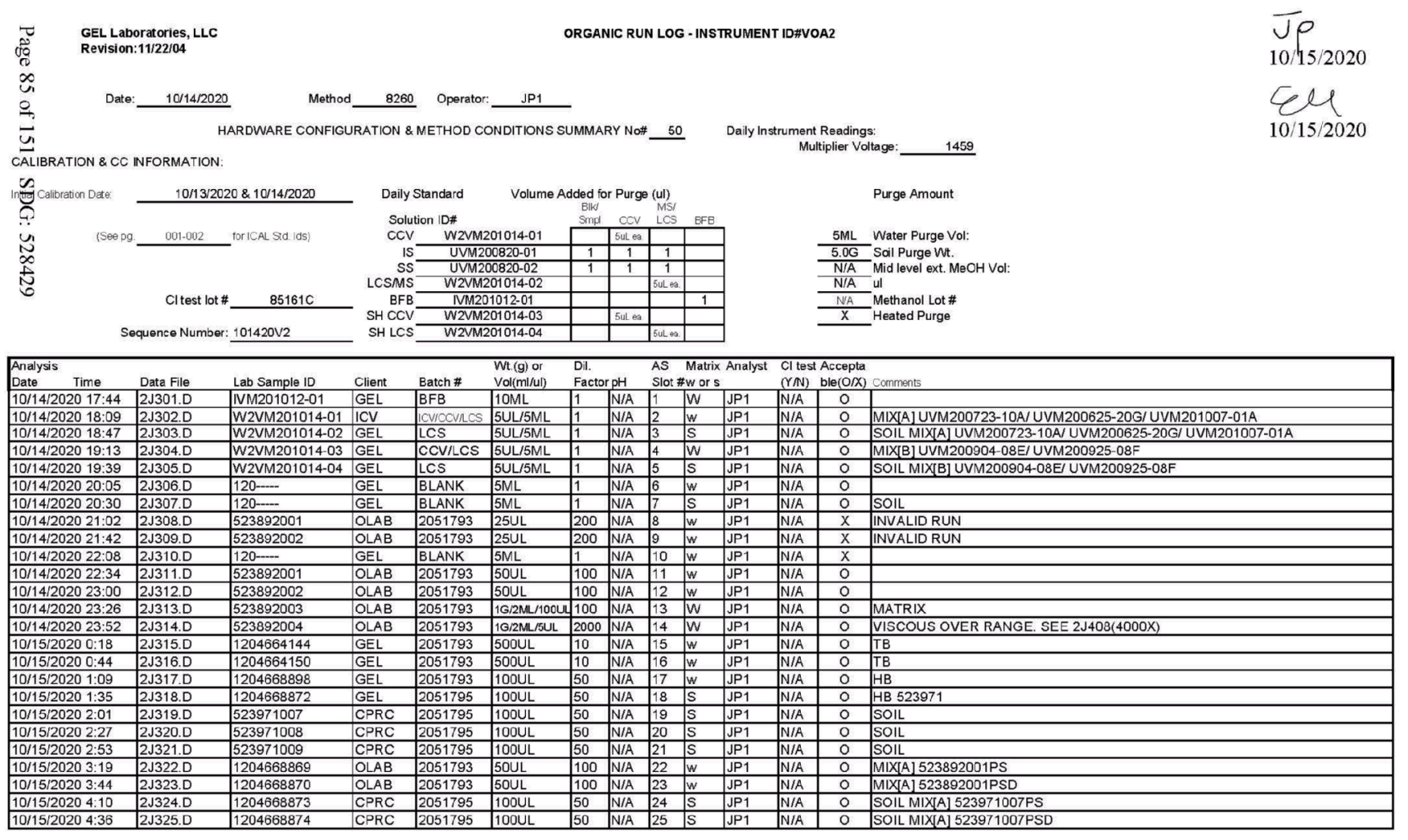




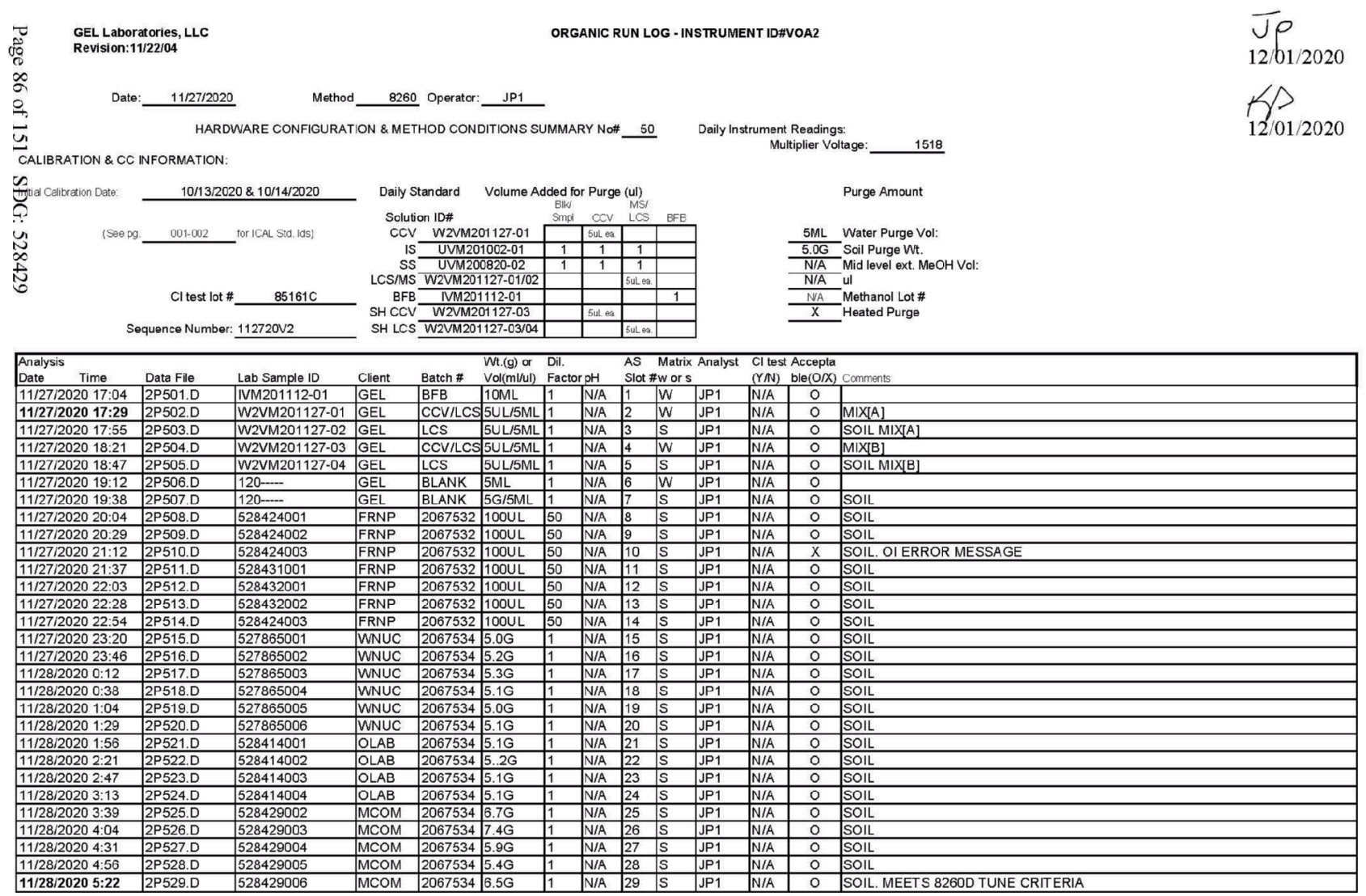




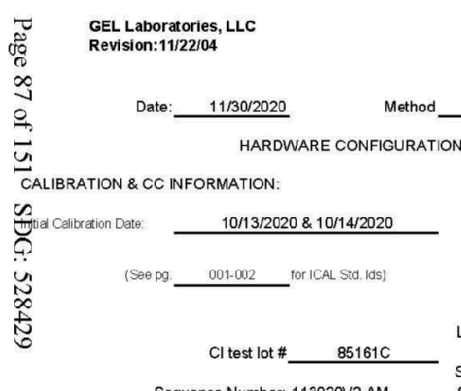
\begin{tabular}{l|l|l|l|l|l|}
\hline SH CCV & W2VM201130-07 & & 5ul ea & & \\
\hline SH LCS & W2VM201130-07 & & & 5uL La & \\
\hline
\end{tabular}

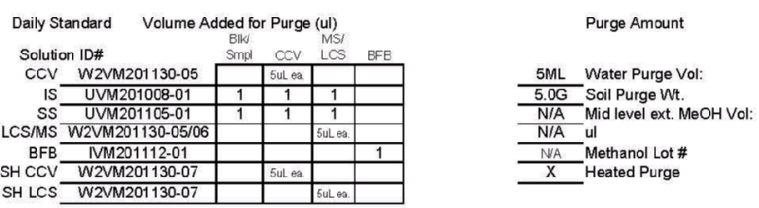

\begin{tabular}{|c|c|c|c|c|c|c|c|c|c|c|c|c|c|}
\hline $\begin{array}{|ll|}\text { Analysis } & \\
\text { Date } & \text { Time } \\
\end{array}$ & Data File & Lab Sample ID & Client & Eatch \# & $\begin{array}{l}\text { Wt.(g) or } \\
\text { Vol(mi/ul) }\end{array}$ & $\begin{array}{l}\text { Dil. } \\
\text { Facto }\end{array}$ & & $\begin{array}{l}\text { AS } \\
\text { Slot \# }\end{array}$ & $\begin{array}{l}\text { Mat } \\
\text { \#w or }\end{array}$ & Analyst & $\begin{array}{l}\text { Cl tes } \\
(Y N)\end{array}$ & $\begin{array}{l}\text { Accepta } \\
\text { Dle(O/X) }\end{array}$ & Comments \\
\hline \begin{tabular}{|lll}
$11 / 30 / 2020$ & $18: 44$
\end{tabular} & 2Q101.D & IVM201112-01 & GEL & BFB & $10 \mathrm{ML}$ & 1 & N/A & 1 & W & JP1 & N N/A & 0 & \\
\hline $\begin{array}{lll}11 / 30 / 2020 & 19: 10 \\
\end{array}$ & 2Q102.D & W2VM201130-01 & GEL & $\mathrm{CCV}$ & $5 U L / 5 M L$ & 1 & N/A & 2 & w & JP1 & N/A & $x$ & MIX[A]DUSE \\
\hline $\begin{array}{lll}11 / 30 / 2020 & 19: 36 \\
\end{array}$ & $20103 . D$ & W2VM201130-02 & GEL & LCS & $5 U L / 5 M L$ & 1 & N/A & 3 & s & JP1 & $N / A$ & $x$ & SOIL MIX[A] DUSE \\
\hline $11 / 30 / 202020: 01$ & $2 Q 104 . D$ & W2VM201130-03 & GEL & $\mathrm{CCV}$ & 5UL/5ML & 1 & N/A & 4 & W & JP1 & $N / A$ & $x$ & MIX[A]DUSE \\
\hline $11 / 30 / 202020: 28$ & 2Q105.D & W2VM201130-04 & GEL & $\begin{array}{ll}\text { LCS } \\
\end{array}$ & 5ULI5ML & 1 & N/A & $\frac{7}{5}$ & s & $\mathrm{JP} 1$ & NIA & $\frac{n}{x}$ & SOIL MIX[A] DUSE \\
\hline $11 / 30 / 202020: 54$ & 2Q106.D & W2VM201130-05 & GEL & CCVILCS & $5 \mathrm{CL} / 5 \mathrm{ML}$ & 1 & N/A & 6 & w & JP1 & N/A & 0 & MIXIA]UVM200820-12E/UVM200821-10F/UVM201007-01D \\
\hline $11 / 30 / 202021: 20$ & $2 Q 107 . \mathrm{D}$ & W2VM201130-06 & GEL & LCS & $5 U L / 5 M L$ & 1 & N/A & 7 & s & JP1 & N/A & 0 & SOIL MIXIA] UVM200820-12E/UVM200821-10F/UVM201007-01D \\
\hline $11 / 30 / 202021: 46$ & 2Q108.D & W2VM201130-07 & GEL & CCV/LCS & $5 U L / 5 M L$ & 1 & N/A & 8 & $\mathrm{w}$ & JP1 & N/A & 0 & MIXIB] UVM 201029-08C/UVM201029-16B \\
\hline $11 / 30 / 202022: 12$ & 2Q109.D & $120-0$ & GEL & BLANK & $5 \mathrm{ML}$ & 1 & N/A & 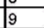 & w & JP1 & NIA & o & \\
\hline $11 / 30 / 202022: 38$ & 2Q110.D & $120-$ & GEL & BLANK & $5 \mathrm{ML}$ & 1 & N/A & 10 & s & JP1 & $\mathrm{N} / \mathrm{A}$ & 0 & SOIL \\
\hline $11 / 30 / 202023: 04$ & $2 Q 111 . \mathrm{D}$ & 1204704006 & FRNP & 2067338 & $5 \mathrm{ML}$ & 1 & $\mathrm{PH}<2$ & 11 & w & JP1 & N/A & 0 & MIX[A] $527641002 P S$ \\
\hline 11/30/2020 23:30 & 2Q112. D & 1204704007 & FRNP & 2067338 & $5 \mathrm{ML}$ & 1 & $\mathrm{PH}<2$ & 12 & w & JP1 & N/A & $\mathrm{O}$ & MIX[A] 527641002PSD \\
\hline 11/30/2020 23:56 & $2 Q 113 . D$ & 1204704443 & FRNP & 2067532 & $100 \mathrm{LL}$ & 50 & N/A & 13 & s & JP1 & $\mathrm{N} / \mathrm{A}$ & 0 & SOIL MIX[A] 528424001PS \\
\hline $12 / 1 / 20200: 21$ & $2 Q 114 . D$ & 1204704444 & FRNP & 2067532 & $100 \mathrm{UL}$ & 50 & N/A & 14 & s & JP1 & $\mathrm{N} / \mathrm{A}$ & 0 & SOIL MIX[A] $528424001 \mathrm{PSD}$ \\
\hline $12 / 1 / 20200: 47$ & 2Q115.D & 1204704450 & OLAB & 2067534 & $5.0 \mathrm{G}$ & 1 & N/A & 15 & s & JP1 & $N / A$ & 0 & SOIL MIX[A] 528414001PS \\
\hline $12 / 1 / 20201: 13$ & 2Q116.D & 1204704451 & $O L A B$ & 2067534 & $5.0 \mathrm{G}$ & 1 & N/A & 16 & s & JP1 & NSA & $\mathrm{O}$ & SOIL MIXIA] 528414001PSD \\
\hline $12 / 1 / 20201: 38$ & $20117 . \mathrm{D}$ & $120+\ldots$ & GEL & N/A & N/A & 1 & N/A & 17 & w & JP1 & NI/A & $x$ & INVALID RUN OVERRANGE 2-BUTANONE/2.PENTANONE/4-METHYL-2.PENTANONE \\
\hline $12 / 1 / 20202: 04$ & 2Q118.D & 120 & GEL & BLANK & $5 \mathrm{ML}$ & 1 & N/A & 18 & w & JP1 & $\mathrm{N} / \mathrm{A}$ & $\mathrm{x}$ & \\
\hline $12 / 1 / 20202: 30$ & 2Q119.D & 1204704440 & GEL & 2067532 & $100 \mathrm{UL}$ & 50 & N/A & 19 & s & JP1 & N/A & $x$ & SOIL HB 11-27-20 2-BUTANONE 8.26 \\
\hline $12 / 1 / 20202: 56$ & 2Q120.D & 1204705490 & GEL & 2068007 & $100 \mathrm{UL}$ & 50 & N/A & 20 & s & JP1 & N/A & $\mathrm{x}$ & SOIL HB 11-30-20 2-BUTANONE 5.65 \\
\hline $12 / 1 / 20203: 22$ & $2 Q 121 . D$ & 527867001 & $3 \mathrm{VIN}$ & 2067534 & 3.96 & 1 & N/A & $\frac{20}{21}$ & $\frac{1}{s}$ & JP1 & N/A & $\hat{x}$ & SOIL \\
\hline $12 / 1 / 20203: 48$ & $20122 . \mathrm{D}$ & 527839001 & CARE & 2068007 & $100 \mathrm{UL}$ & 50 & N/A & 22 & s & JP1 & $\mathrm{N} / \mathrm{A}$ & $\hat{x}$ & SOIL \\
\hline $12 / 1 / 20204: 14$ & 2Q123.D & 527840001 & CARE & 2068007 & $100 \mathrm{UL}$ & 50 & N/A & 23 & s & JP1 & N/A & $\frac{x}{x}$ & SOIL \\
\hline $12 / 1 / 20204: 40$ & $2 Q 124 . D$ & 527840002 & CARE & 2068007 & $100 \mathrm{UL}$ & 50 & N/A & 24 & s & JP1 & $N / A$ & $x$ & SOIL \\
\hline $12 / 1 / 20205: 05$ & $\frac{2 Q 125 . D}{2 Q 125 . D}$ & $\frac{528035001}{2}$ & BOEN & $\frac{20607534}{2073}$ & $100 \mathrm{UL}$ & 50 & N/A & $\frac{24}{25}$ & $\frac{2}{2}$ & JP1 & N/A $/ A$ & $\hat{x}$ & SOIL \\
\hline $12 / 1 / 20205: 31$ & $2 Q 126 . D$ & 528035002 & BOEN & $\frac{2067534}{20674}$ & $100 \mathrm{UL}$ & 50 & N/A & $\frac{26}{26}$ & s & JP1 & N/A & $\hat{x}$ & SOIL \\
\hline $12 / 1 / 20205: 58$ & 2Q127.D & 528163001 & NRTH & 2067534 & $3.9 \mathrm{G}$ & 1 & N/A & 27 & s & JP1 & $N / A$ & $x$ & SOIL \\
\hline $12 / 1 / 20206: 24$ & $2 Q 128 . D$ & 528163002 & NRTH & 2067534 & $4.3 \mathrm{G}$ & 1 & N/A & 28 & s & JP1 & $\mathrm{N} / \mathrm{A}$ & $x$ & SOIL \\
\hline
\end{tabular}




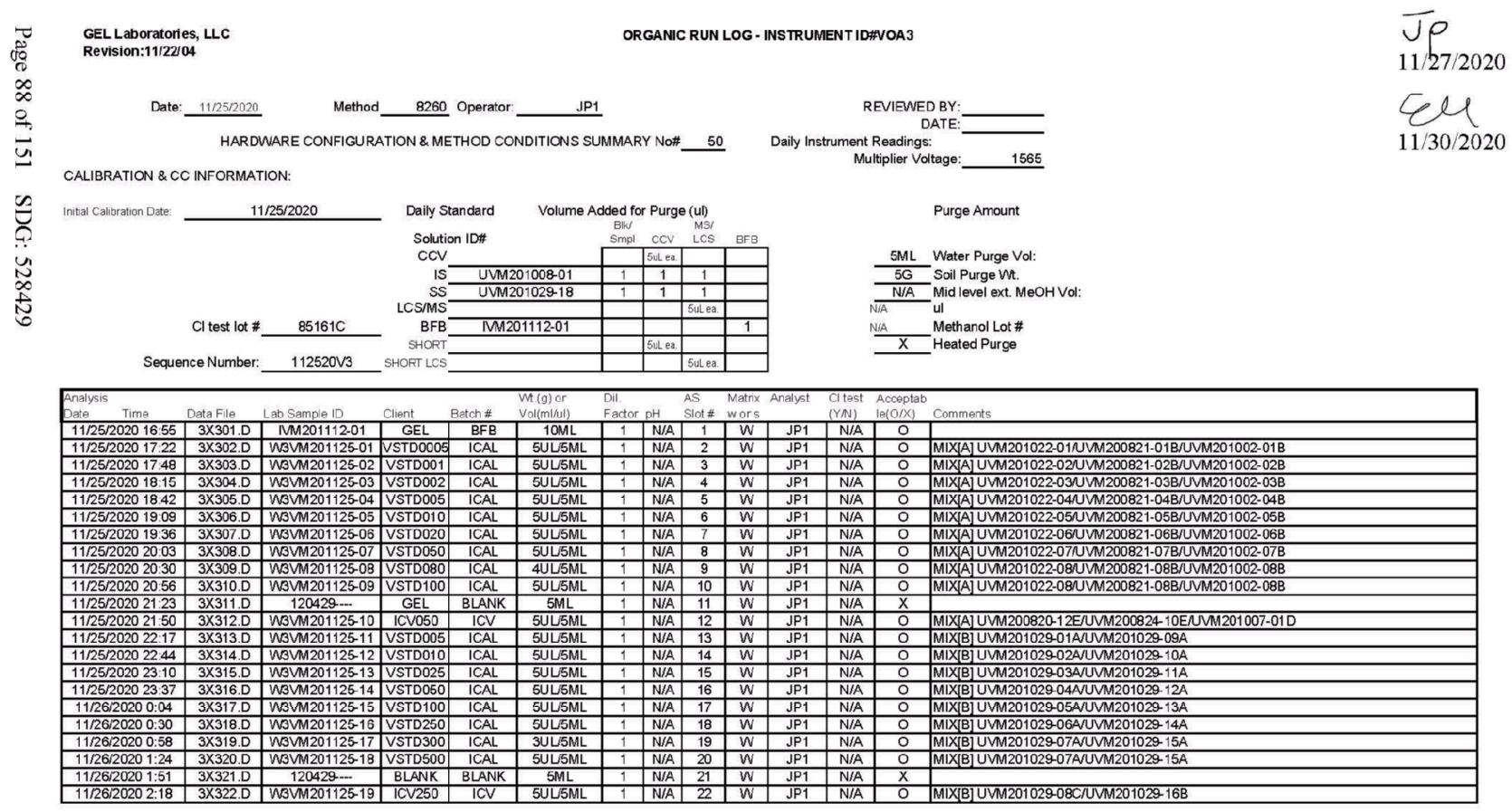




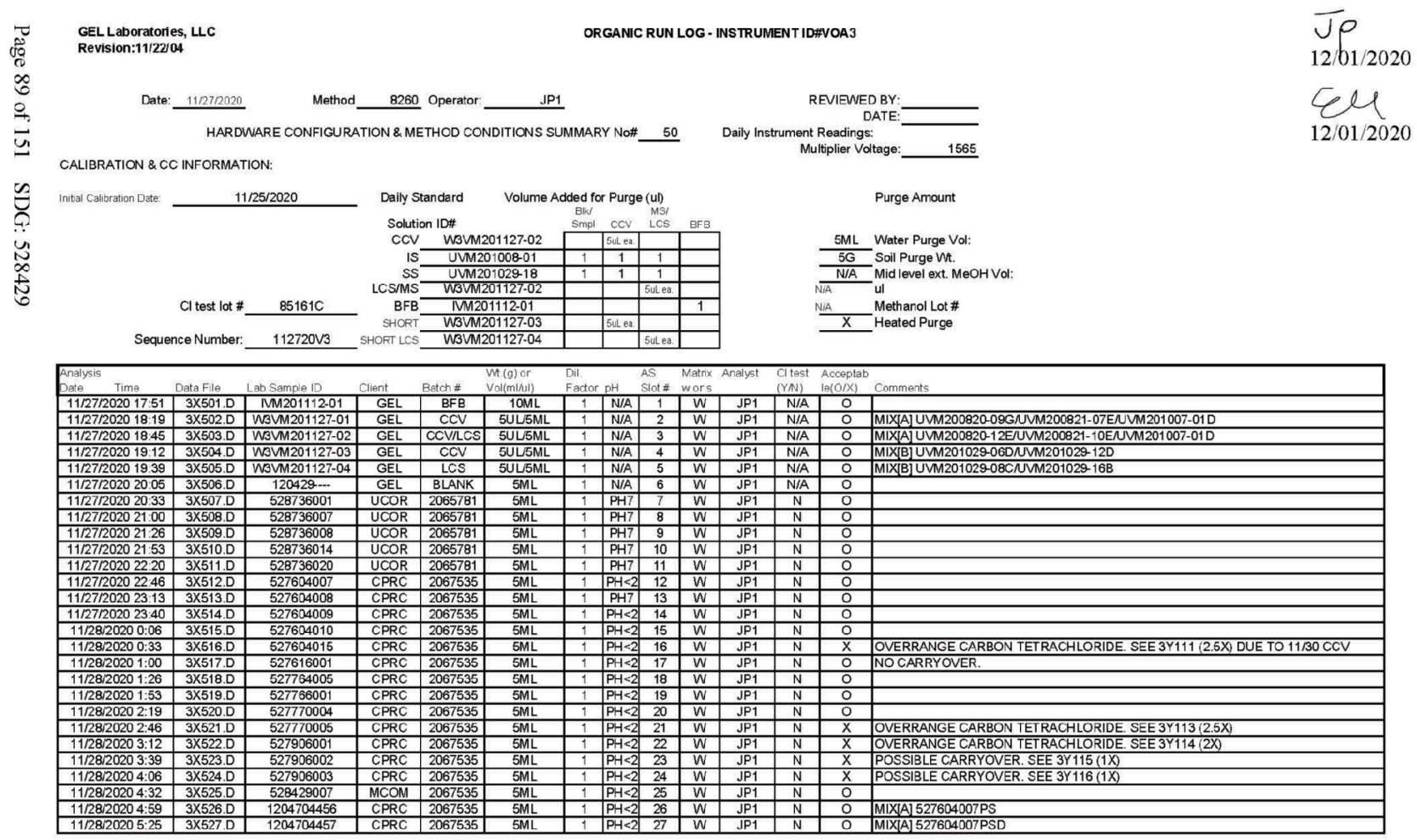




\section{Semi-Volatile Analysis}

Page 90 of 151 SDG: 528429 


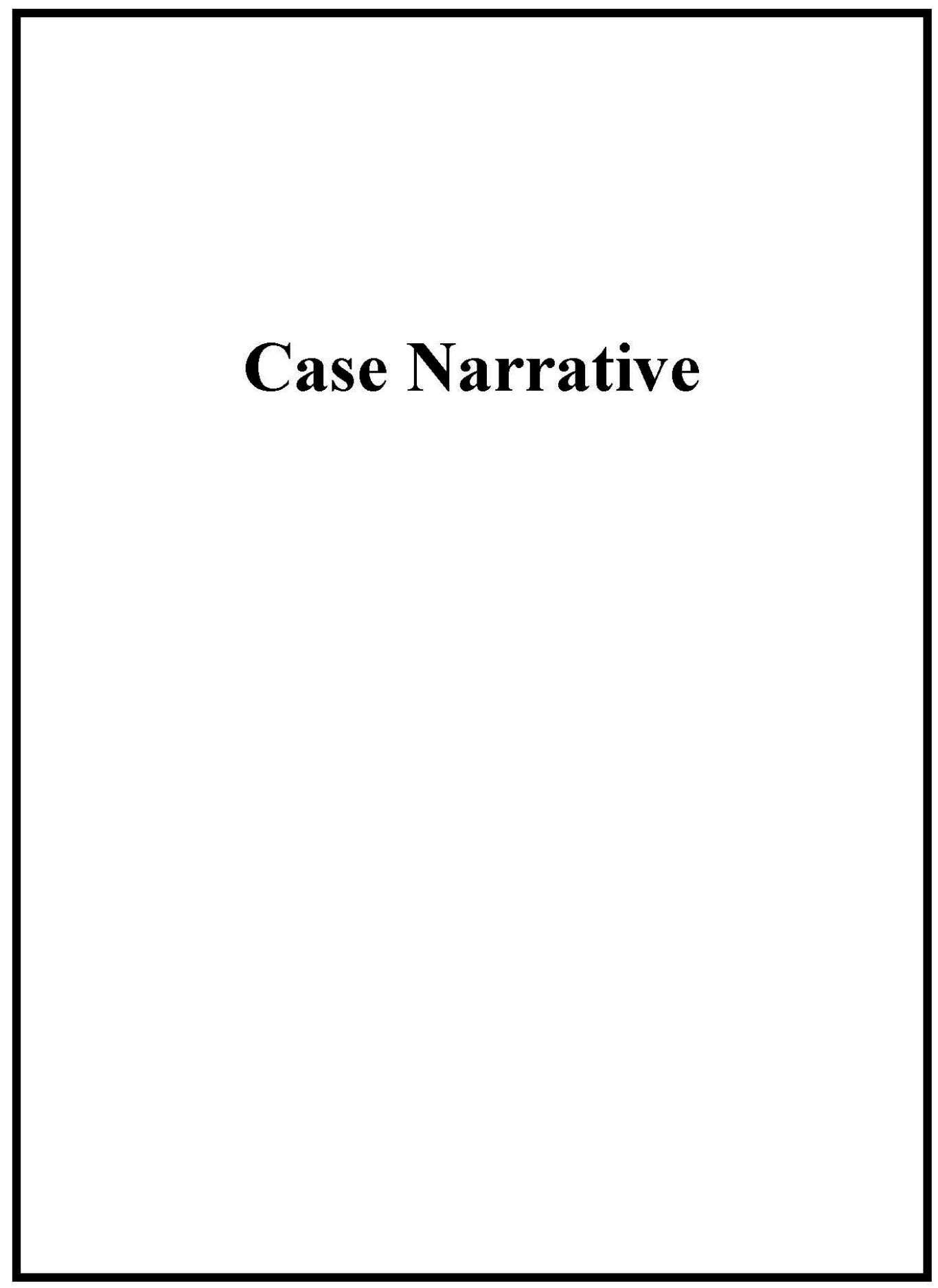

Page 91 of 151 SDG: 528429 
GC/MS Semivolatile

Technical Case Narrative

Marcom LLC

SDG \#: $\mathbf{5 2 8 4 2 9}$

Product: Analysis of Semivolatile Organic Compounds by Gas Chromatography/Mass Spectrometry Analytical Method: SW846 3541/8270D SIM PAH

Analytical Procedure: GL-OA-E-009 REV\# 45

Analytical Batch: 2067376

Preparation Method: SW846 3541

Preparation Procedure: GL-OA-E-066 REV\# 9

Preparation Batch: 2067375

The following samples were analyzed using the above methods and analytical procedure(s).

\begin{tabular}{|c|c|}
\hline GEL Sample ID\# & Client Sample Identification \\
\hline 528429002 & TANN20006 \\
\hline 528429003 & TANN20007 \\
\hline 528429004 & TANN20008 \\
\hline 528429005 & TANN20009 \\
\hline 528429006 & TANN20010 \\
\hline 1204704080 & Method Blank (MB) \\
\hline 1204704081 & Laboratory Control Sample (LCS) \\
\hline 1204704082 & 527597001(NonSDG) Matrix Spike (MS) \\
\hline 1204704083 & 527597001(NonSDG) Matrix Spike Duplicate (MSD) \\
\hline
\end{tabular}

The samples in this SDG were analyzed on a "dry weight" basis.

\section{Data Summary:}

All sample data provided in this report met the acceptance criteria specified in the analytical methods and procedures for initial calibration, continuing calibration, instrument controls and process controls where applicable, with the following exceptions.

\section{Quality Control (QC) Information}

\section{Spike Recovery Statement}

The MS (See Below) did not meet spike recovery acceptance criteria. The MS, along with the parent and MSD, were analyzed at a dilution. There were multiple target anlytes detected above the reporting limits in the un-spike parent sample that caused a biased calculated result in the MS. The data results have been reported.

\begin{tabular}{|l|l|l|}
\hline \multicolumn{1}{|c|}{ Sample } & \multicolumn{1}{c|}{ Analyte } & \multicolumn{1}{c|}{ Value } \\
\hline 1204704082 (Non SDG 527597001MS) & Benzo(a)pyrene & $16 *(24 \%-129 \%)$ \\
\hline & Benzo(b)fluoranthene & $0^{*}(22 \%-130 \%)$ \\
\hline & Chrysene & $0 *(31 \%-119 \%)$ \\
\hline & Fluoranthene & $0 *(21 \%-122 \%)$ \\
\hline & Naphthalene & $15 *(29 \%-122 \%)$ \\
\hline & Pyrene & $0 *(19 \%-139 \%)$ \\
\hline
\end{tabular}

Page 92 of 151 SDG: 528429 
MS/MSD Relative Percent Difference (RPD) Statement

The RPD values between the MS and MSD, (See Below) were not within the acceptance limits. The MS, along with the parent and MSD, were analyzed at a dilution. The RPD failures were attributed to the biased calculated results in the MS and MSD that resulted from multiple detected presences of target analytes above the reporting limits in the un-spike parent sample. The data results have been reported.

\begin{tabular}{|l|l|l|}
\hline \multicolumn{1}{|c|}{ Sample } & \multicolumn{1}{|c|}{ Analyte } & \multicolumn{1}{c|}{ Value } \\
\hline 1204704082MS and 1204704083MSD (Non SDG 527597001) & Acenaphthene & $81 *(0 \%-30 \%)$ \\
\hline & Anthracene & $76 *(0 \%-30 \%)$ \\
\hline & Benzo(a)pyrene & $69 *(0 \%-30 \%)$ \\
\hline & Benzo(b)fluoranthene & $70 *(0 \%-30 \%)$ \\
\hline & Benzo(k)fluoranthene & $73 *(0 \%-30 \%)$ \\
\hline & Chrysene & $70 *(0 \%-30 \%)$ \\
\hline & Fluoranthene & $66 *(0 \%-30 \%)$ \\
\hline & Fluorene & $79 *(0 \%-30 \%)$ \\
\hline & Naphthalene & $86 *(0 \%-30 \%)$ \\
\hline & Pyrene & $65 *(0 \%-30 \%)$ \\
\hline
\end{tabular}

Internal Standard (ISTD) Acceptance

The internal standard response for 1,4-Dichlorobenzene-d4 was outside of the acceptance criteria for sample 528429006 (TANN20010). Since 1,4-Dichlorobenzene-d4 was not used to quantitate the requested target analytes or surrogates for this batch, the data were not adversely impacted by the failure. The results are reported.

\section{Technical Information}

\section{Sample Dilutions}

Samples 528429002 (TANN20006), 528429003 (TANN20007), 528429004 (TANN20008), 528429005

(TANN20009) and 528429006 (TANN20010) were diluted due to the presence of non-target analytes. The data from the dilutions are reported.

\section{Miscellaneous Information}

\section{Additional Comments}

The additional comments field is used to address special issues associated with each analysis, clarify $\mathrm{method} /$ contractual issues pertaining to the analysis, and to list any report documents generated as a result of sample analysis or review. The following additional comments were required:

Due to this SDG requesting two separate method criteria, 8270D SIM PAH with 3541 Prep in Solid and 8270C SIM PAH in Liquid, the batches being analyzed on the same instrument, certain forms cannot be generated for both methods due to software limitations. All raw data associated with samples 528429002 (TANN20006), 528429003 (TANN20007), 528429004 (TANN20008), 528429005 (TANN20009) and 528429006 (TANN20010) has been provided.

Product: Analysis of Semivolatile Organic Compounds by Gas Chromatography/Mass Spectrometry Analytical Method: SW $8463510 \mathrm{C} / 8270 \mathrm{C}$ SIM PAH Analytical Procedure: GL-OA-E-009 REV\# 45

Page 93 of 151 SDG: 528429 
Analytical Batch: 2067384

Preparation Method: SW846 3510C

Preparation Procedure: GL-OA-E-013 REV\# 34

Preparation Batch: 2067383

The following samples were analyzed using the above methods and analytical procedure(s)

GEL Sample ID\#

528429001

1204704097

1204704098

1204704099

\section{Client Sample Identification} FIELD BLANK

Method Blank (MB)

Laboratory Control Sample (LCS)

Laboratory Control Sample Duplicate (LCSD)

The samples in this SDG were analyzed on an "as received" basis.

Data Summary:

All sample data provided in this report met the acceptance criteria specified in the analytical methods and procedures for initial calibration, continuing calibration, instrument controls and process controls where applicable, with the following exceptions.

\section{Quality Control (QC) Information}

Laboratory Control Sample Duplicate (LCSD)

An LCSD was used in place of matrix QC due to limited sample volume.

Laboratory Control Sample (LCS) Recovery

The LCS spike recoveries were not within the acceptance limits. The associated LCSD passed recoveries. It appears that the low spike recoveries were isolated to the LCS only and were the result of a poor extraction.

\begin{tabular}{|c|l|l|}
\hline \multicolumn{1}{|c|}{ Sample } & \multicolumn{1}{|c|}{ Analyte } & \multicolumn{1}{c|}{ Value } \\
\hline 1204704098 (LCS) & Acenaphthene & $46^{*}(62 \%-98 \%)$ \\
\hline & Anthracene & $46 *(60 \%-105 \%)$ \\
\hline & Benzo(a)anthracene & $43 *(60 \%-104 \%)$ \\
\hline & Benzo(a)pyrene & $46 *(61 \%-106 \%)$ \\
\hline & Benzo(b)fluoranthene & $45^{*}(60 \%-107 \%)$ \\
\hline & Benzo(k)fluoranthene & $42 *(59 \%-109 \%)$ \\
\hline & Chrysene & $48 *(62 \%-105 \%)$ \\
\hline & Fluoranthene & $48 *(56 \%-107 \%)$ \\
\hline & Fluorene & $49 *(58 \%-104 \%)$ \\
\hline & Naphthalene & $39 *(64 \%-93 \%)$ \\
\hline & Pyrene & $50 *(55 \%-112 \%)$ \\
\hline & &
\end{tabular}

LCS/LCSD Relative Percent Difference (RPD) Statement

The RPD values between the LCS and LCSD (See Below) were not within the acceptance limits due to the large difference between the individual recoveries in each LCS and LCSD analyte pair. The failures may be attributed to an error in the extraction process.

Page 94 of 151 SDG: 528429 


\begin{tabular}{|l|l|l|}
\hline \multicolumn{1}{|c|}{ Sample } & \multicolumn{1}{|c|}{ Analyte } & \multicolumn{1}{c|}{ Value } \\
\hline $\begin{array}{l}1204704098(\text { LCS }) \text { and } 1204704099 \\
\text { (LCSD) }\end{array}$ & Acenaphthene & $\begin{array}{l}\text { RPD 47* } \\
(0 \%-20 \%)\end{array}$ \\
\hline & Anthracene & $\begin{array}{l}\text { RPD 50* } \\
(0 \%-22 \%)\end{array}$ \\
\hline & Benzo(a)anthracene & $\begin{array}{l}\text { RPD 47* } \\
(0 \%-20 \%)\end{array}$ \\
\hline & $\begin{array}{l}\text { Benzo(a)pyrene, Benzo(b)fluoranthene, } \\
\text { Benzo(k)fluoranthene }\end{array}$ & $\begin{array}{l}\text { RPD 48* } \\
(0 \%-20 \%)\end{array}$ \\
\hline & Chrysene & $\begin{array}{l}\text { RPD 47* } \\
(0 \%-20 \%)\end{array}$ \\
\hline & Fluoranthene & $\begin{array}{l}\text { RPD 51* } \\
(0 \%-20 \%)\end{array}$ \\
\hline & Fluorene & $\begin{array}{l}\text { RPD 48* } \\
(0 \%-20 \%)\end{array}$ \\
\hline & Naphthalene & $\begin{array}{l}\text { RPD 50* } \\
(0 \%-20 \%)\end{array}$ \\
\hline & Pyrene & $\begin{array}{l}\text { RPD 38* } \\
(0 \%-20 \%)\end{array}$ \\
\hline
\end{tabular}

\section{Technical Information}

Sample Re-extraction/Re-analysis

Sample 1204704097 (MB) was re-analyzed for ISTD failure.

\section{Miscellaneous Information}

\section{Additional Comments}

The additional comments field is used to address special issues associated with each analysis, clarify $\mathrm{method} / \mathrm{contractual}$ issues pertaining to the analysis, and to list any report documents generated as a result of sample analysis or review. The following additional comments were required:

Due to this SDG requesting two separate method criteria, 8270D SIM PAH with 3541 Prep in Solid and 8270C SIM PAH in Liquid, the batches being analyzed on the same instrument, certain forms cannot be generated for both methods due to software limitations. All raw data associated with sample 528429001 (FIELD BLANK) has been provided.

\section{Certification Statement}

Where the analytical method has been performed under NELAP certification, the analysis has met all of the requirements of the NELAC standard unless otherwise noted in the analytical case narrative. 


\author{
GEL LABORATORIES LLC \\ 2040 Savage Road Charleston SC 29407 - (843) 556-8171 - wuw.gel.com \\ Qualifier Definition Report \\ for \\ MCOM001 Marcom LLC \\ Client SDG: 528429 GEL Work Order: 528429
}

\title{
The Qualifiers in this report are defined as follows:
}

* A quality control analyte recovery is outside of specified acceptance criteria

** Analyte is a sunogate compound

J Vahe is estimated

U Analyte was analyzed for, but not detected above the MDL, MDA, MDC or LOD.

DL Indicates that sample is dihuted.

RA Indicates that sample is re-analyzed without re-extraction.

$\mathrm{RE}$ Indicates thats ample is re-extracted.

\section{Review/Vatidation}

GEL requires all analytical data to be verified by a qualified data reviewer. In addition, all CLP-like deliverab les receive a trird level review of the fractional data package.

The following data validator verified the infomation presented in this data report:

Signature: Bubane Banley

Date: 01 DE 2020
Name: Barbara Bailey

Titles Data Validator 


\section{Sample Data Summary}

Page 97 of 151 SDG: 528429 


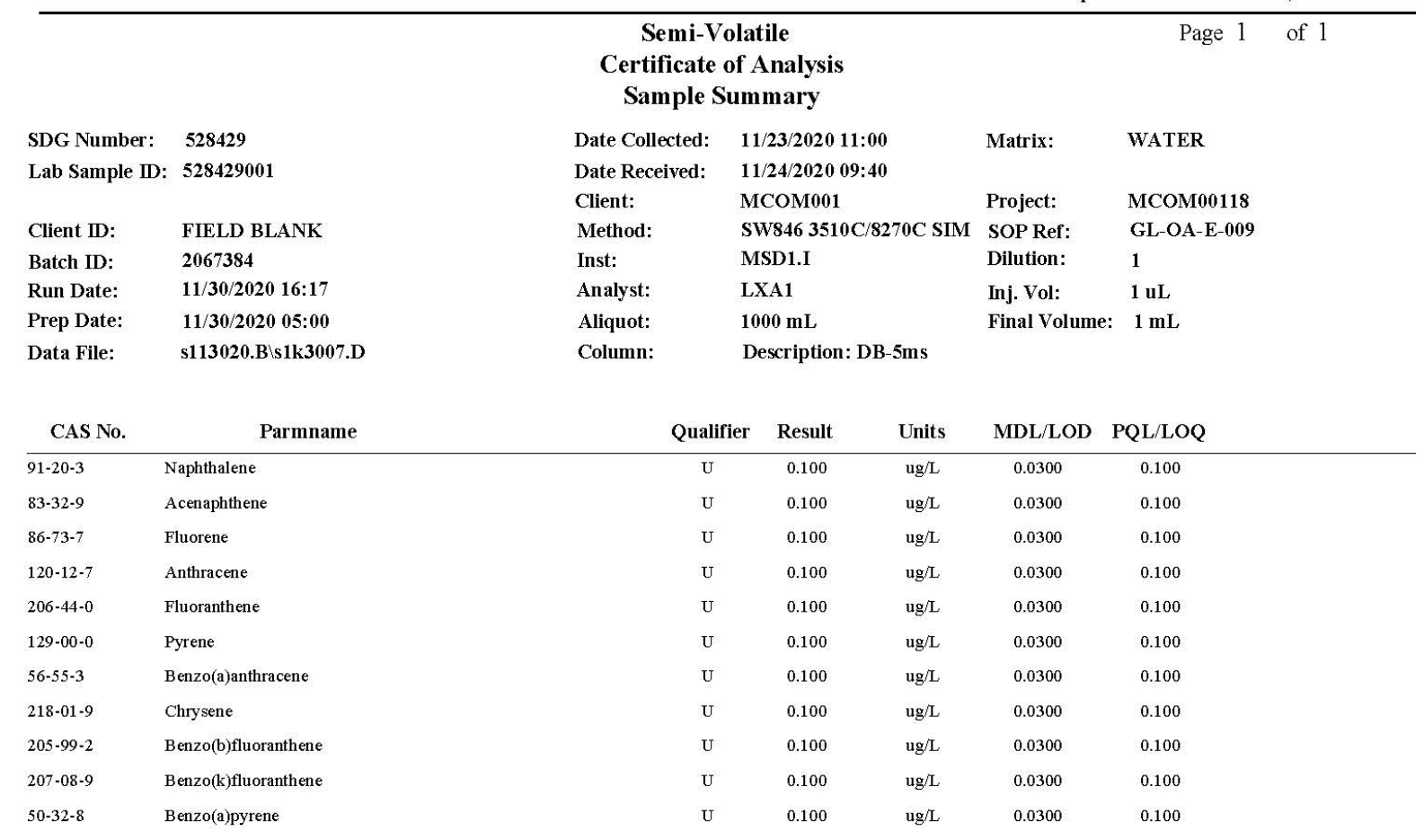

Page 98 of 151 SDG: 528429 


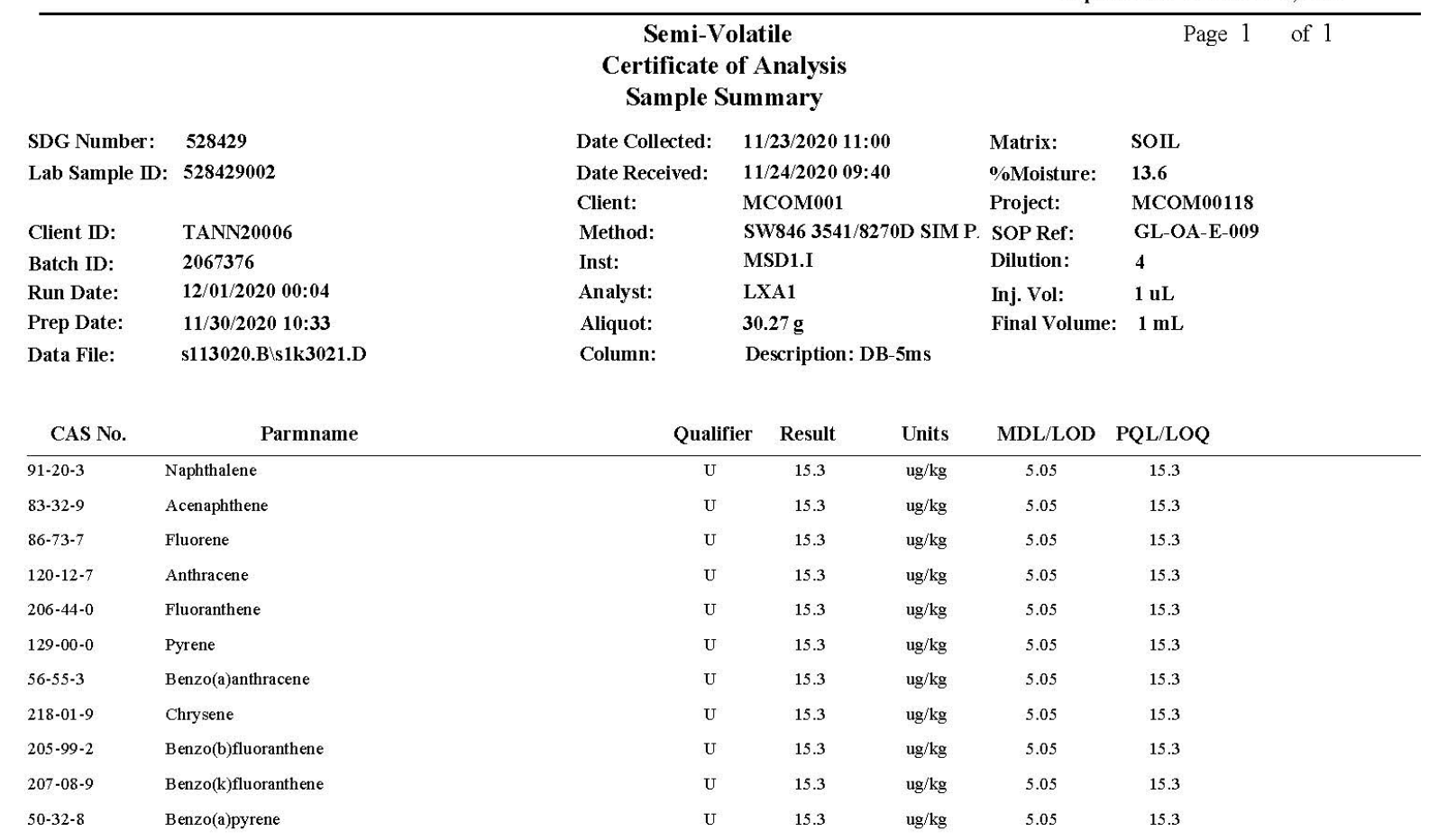




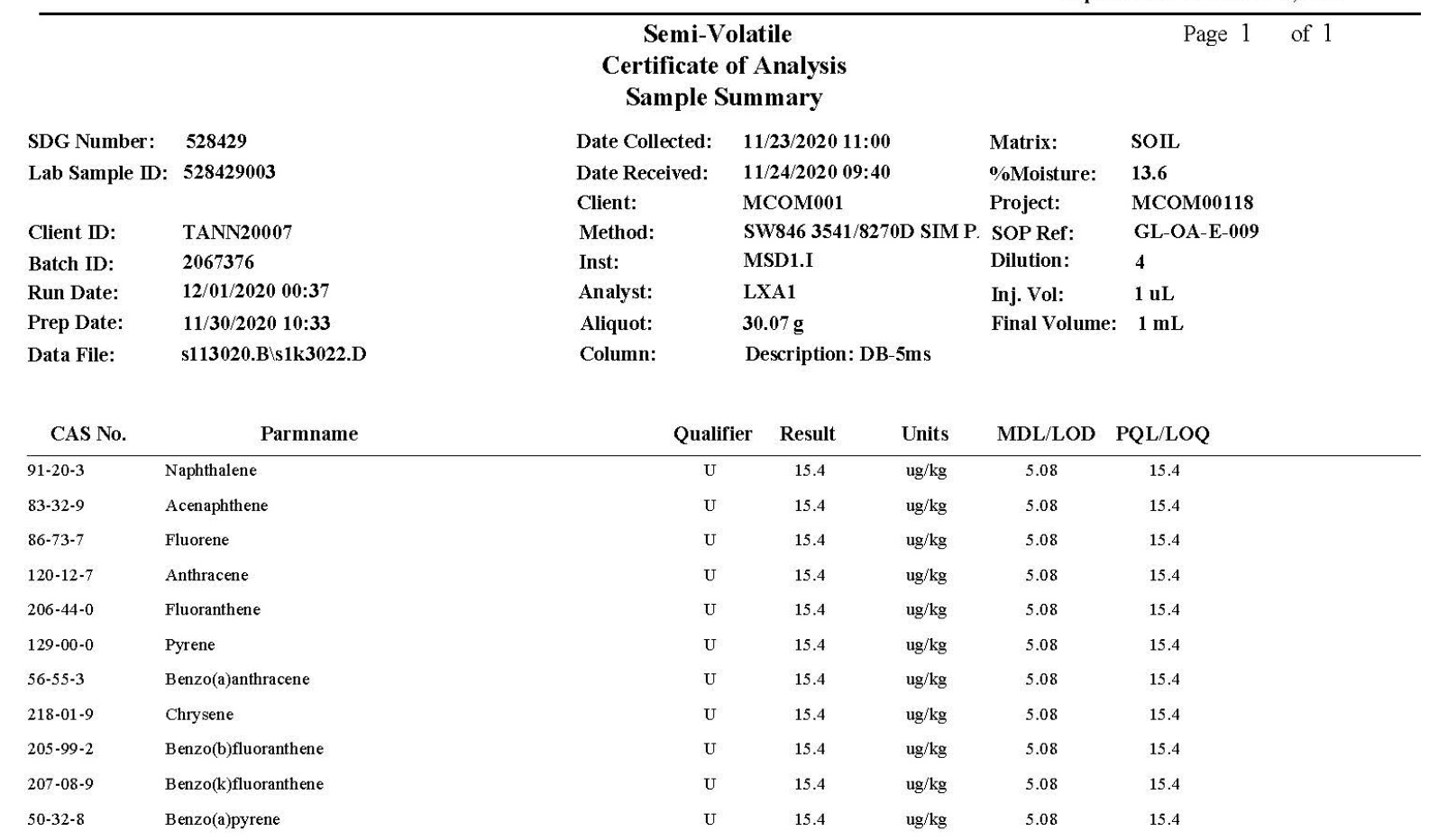

Page 100 of 151 SDG: 528429 


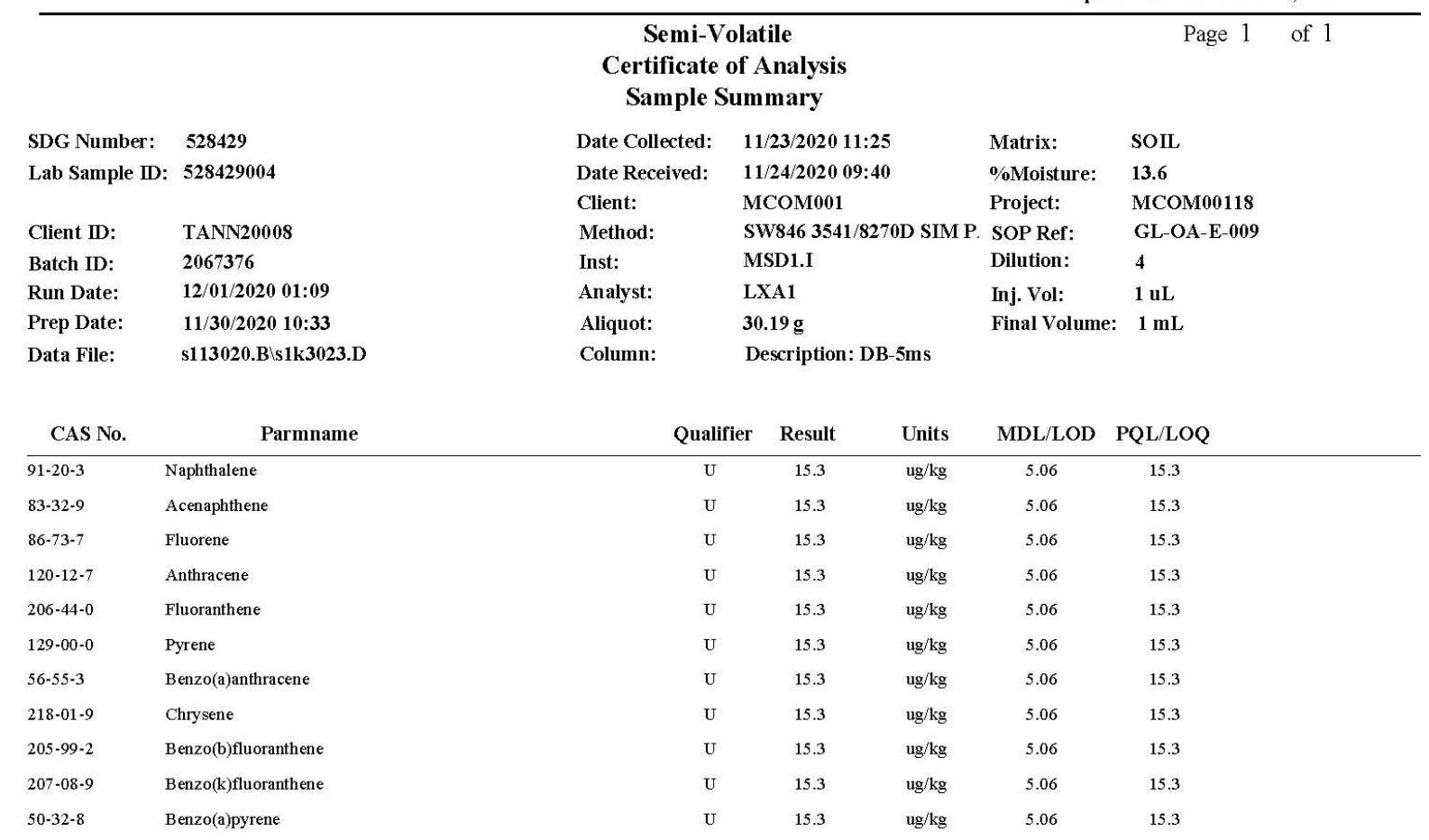

Page 101 of 151 SDG: 528429 


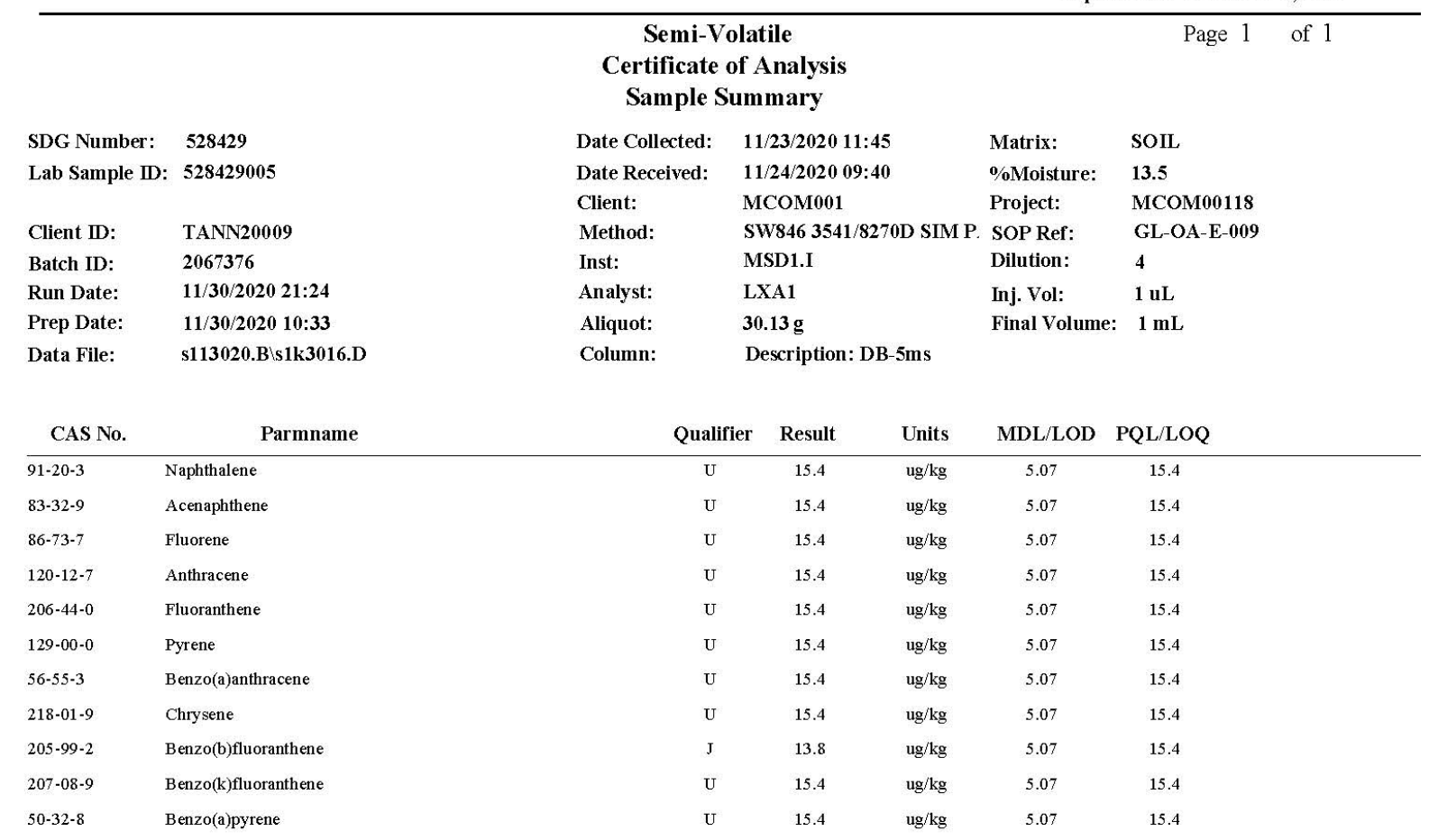

Page 102 of 151 SDG: 528429 


\begin{tabular}{|c|c|c|c|c|c|c|c|}
\hline \multirow{4}{*}{$\begin{array}{l}\text { SDG Number: } \\
\text { Lab Sample ID: }\end{array}$} & \multirow{4}{*}{$\begin{array}{l}\mathbf{5 2 8 4 2 9} \\
: \mathbf{5 2 8 4 2 9 0 0 6}\end{array}$} & \multicolumn{3}{|c|}{$\begin{array}{c}\text { Semi-Volatile } \\
\text { Certificate of Analysis } \\
\text { Sample Summary }\end{array}$} & \multirow{2}{*}{\multicolumn{3}{|c|}{ Page 1 of 1}} \\
\hline & & \multirow{3}{*}{$\begin{array}{l}\text { Date Collected: } \\
\text { Date Received: } \\
\text { Client: }\end{array}$} & \multicolumn{2}{|c|}{$11 / 23 / 202010: 00$} & & & \\
\hline & & & \multicolumn{2}{|c|}{ 11/24/2020 09:40 } & \%Moisture: & 17.5 & \\
\hline & & & \multicolumn{2}{|c|}{ MCOM001 } & Project: & MCOM00118 & \\
\hline Client ID: & TANN20010 & Method: & \multicolumn{2}{|c|}{ SW846 3541/8270D SIM P. } & SOP Ref: & GL-OA-E-009 & \\
\hline Batch ID: & 2067376 & Inst: & \multicolumn{2}{|c|}{ MSD1.I } & Dilution: & 4 & \\
\hline Run Date: & $12 / 01 / 202013: 04$ & Analyst: & \multicolumn{2}{|l|}{ LXA1 } & Inj. Vol: & $1 \mathrm{uL}$ & \\
\hline Prep Date: & $11 / 30 / 202010: 33$ & Aliquot: & \multicolumn{2}{|c|}{$30.33 \mathrm{~g}$} & \multicolumn{3}{|c|}{ Final Volume: $1 \mathrm{~mL}$} \\
\hline Data File: & s120120.B $\backslash s 1 L 0107 . D$ & Column: & \multicolumn{2}{|c|}{ Description: DB-5ms } & & & \\
\hline CAS No. & Parmname & Quali & Result & Units & $\mathrm{MDL} / \mathrm{LOD}$ & PQL/LOQ & \\
\hline $91-20-3$ & Naphthalene & $\mathrm{U}$ & 16.0 & $\mathrm{ug} / \mathrm{kg}$ & 5.27 & 16.0 & \\
\hline $83-32-9$ & Acenaphthene & $\mathrm{U}$ & 16.0 & $\mathrm{ug} / \mathrm{kg}$ & 5.27 & 16.0 & \\
\hline $86-73-7$ & Fluorene & $\mathrm{U}$ & 16.0 & $\mathrm{ug} / \mathrm{kg}$ & 5.27 & 16.0 & \\
\hline $120-12-7$ & Anthracene & $\mathrm{U}$ & 16.0 & $\mathrm{ug} / \mathrm{kg}$ & 5.27 & 16.0 & \\
\hline $206-44-0$ & Fluoranthene & $\mathrm{J}$ & 7.99 & $\mathrm{ug} / \mathrm{kg}$ & 5.27 & 16.0 & \\
\hline $129-00-0$ & Pyrene & & 32.0 & $\mathrm{ug} / \mathrm{kg}$ & 5.27 & 16.0 & \\
\hline $56-55-3$ & Benzo(a)anthracene & $\mathrm{U}$ & 16.0 & $\mathrm{ug} / \mathrm{kg}$ & 5.27 & 16.0 & \\
\hline 218-01-9 & Chrysene & $\mathrm{U}$ & 16.0 & $\mathrm{ug} / \mathrm{kg}$ & 5.27 & 16.0 & \\
\hline $205-99-2$ & Benzo(b)fluoranthene & $\mathrm{U}$ & 16.0 & $\mathrm{ug} / \mathrm{kg}$ & 5.27 & 16.0 & \\
\hline $207-08-9$ & Benzo(k)fluoranthene & $\mathrm{U}$ & 16.0 & $\mathrm{ug} / \mathrm{kg}$ & 5.27 & 16.0 & \\
\hline $50-32-8$ & Benzo(a)pyrene & U & 16.0 & $\mathrm{ug} / \mathrm{kg}$ & 5.27 & 16.0 & \\
\hline
\end{tabular}

Page 103 of 151 SDG: 528429 


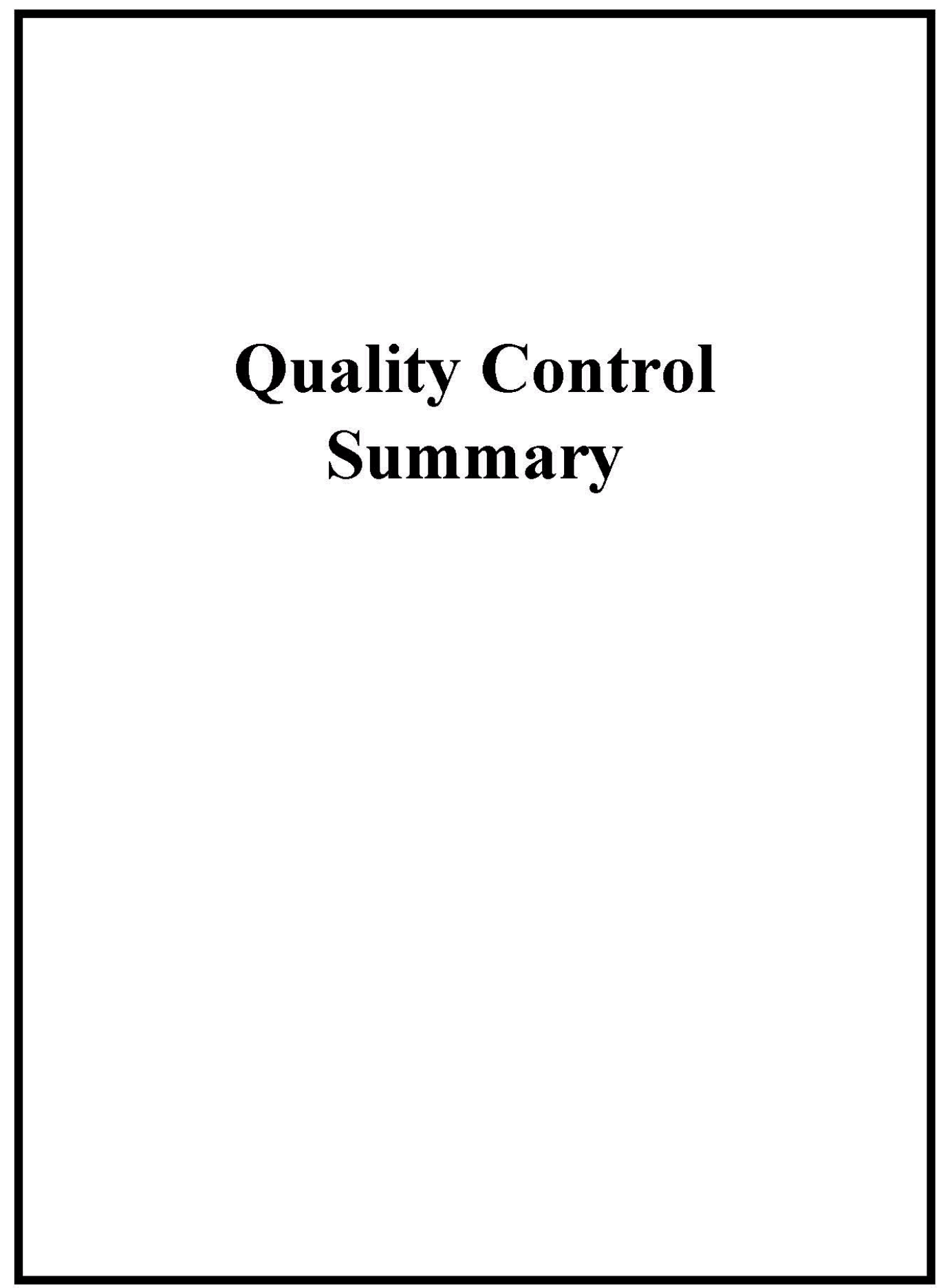

Page 104 of 151 SDG: 528429 


\section{Semi-Volatile \\ Surrogate Recovery Report}

Page 1

of 2

SDG Number: 528429

Matrix Type: LIQUID

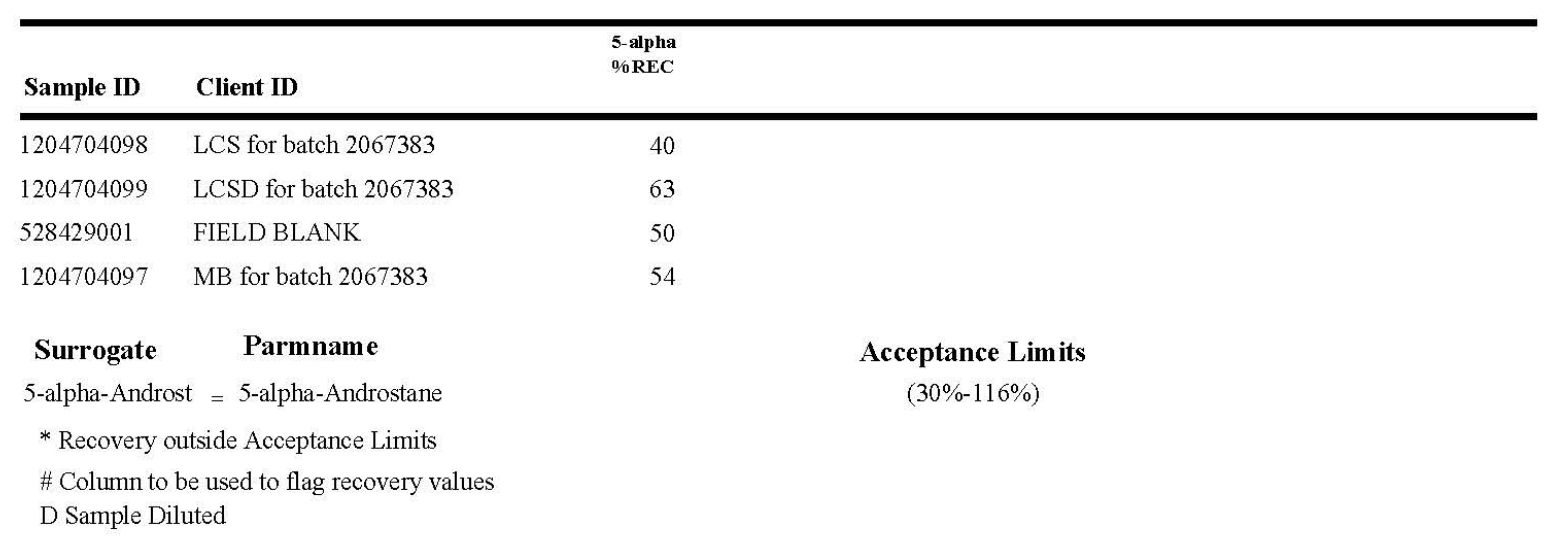

Page 105 of 151 SDG: 528429 


\section{Semi-Volatile \\ Surrogate Recovery Report}

Page 2

SDG Number: $\mathbf{5 2 8 4 2 9}$

Matrix Type: SOLID

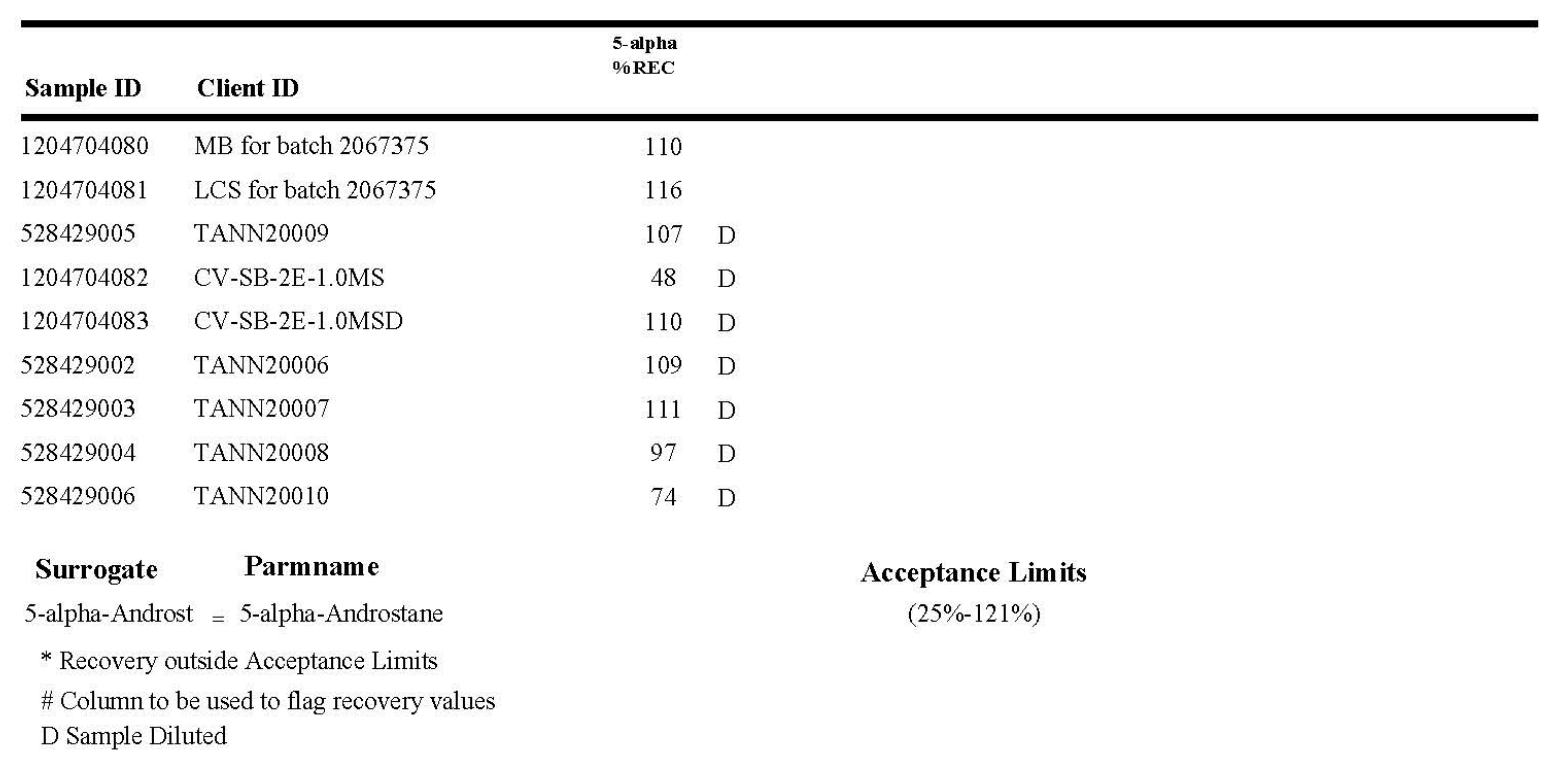

Page 106 of 151 SDG: 528429 


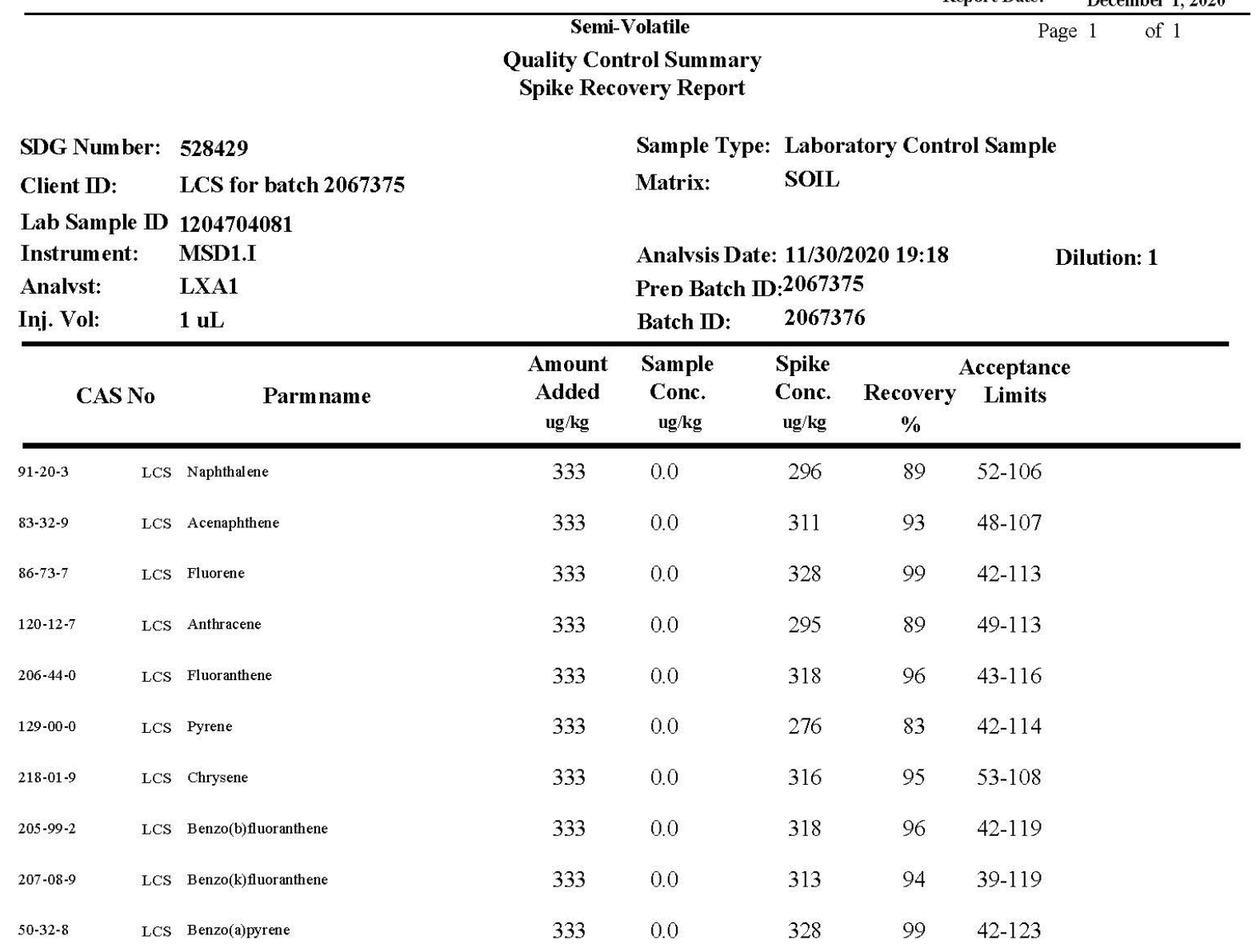




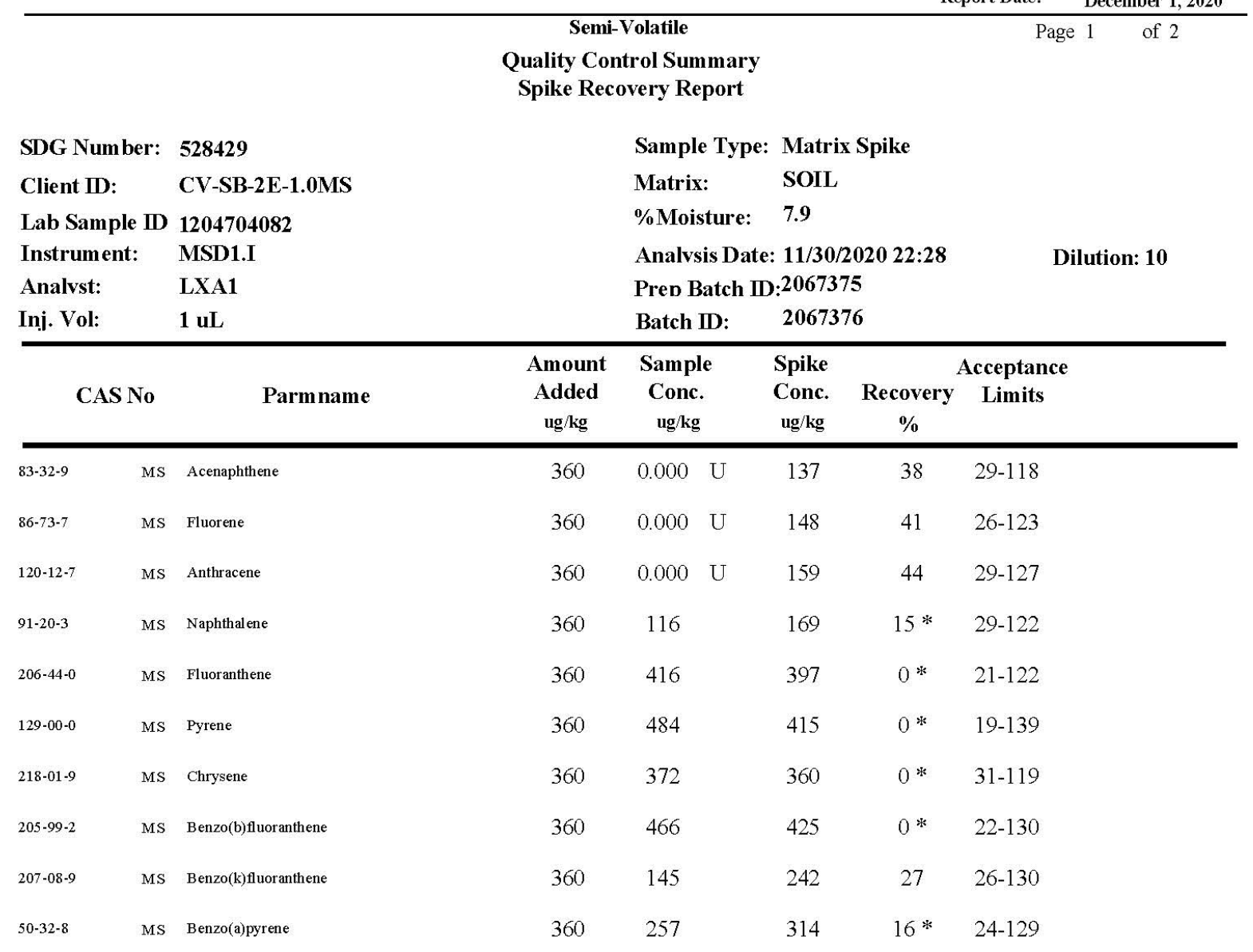




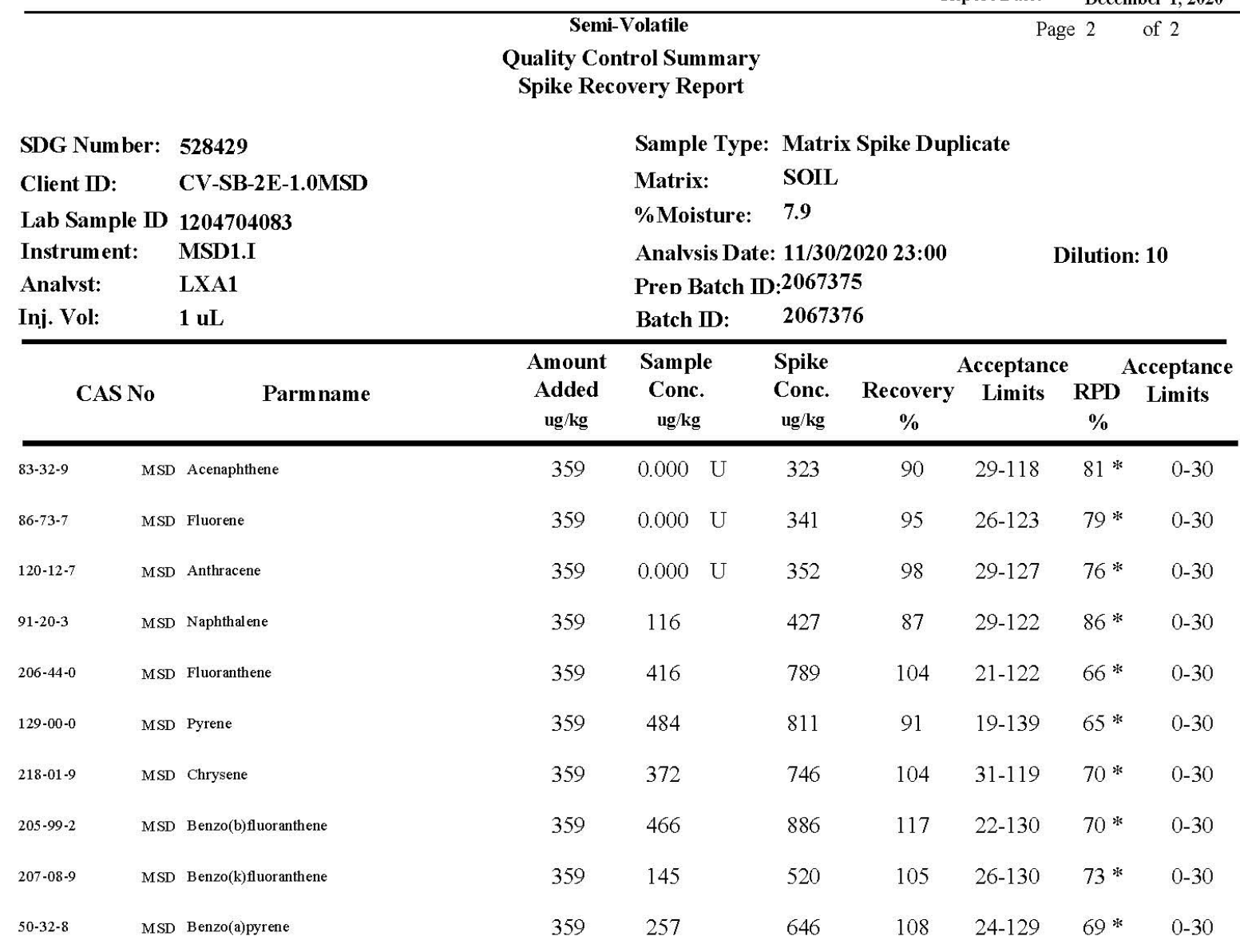




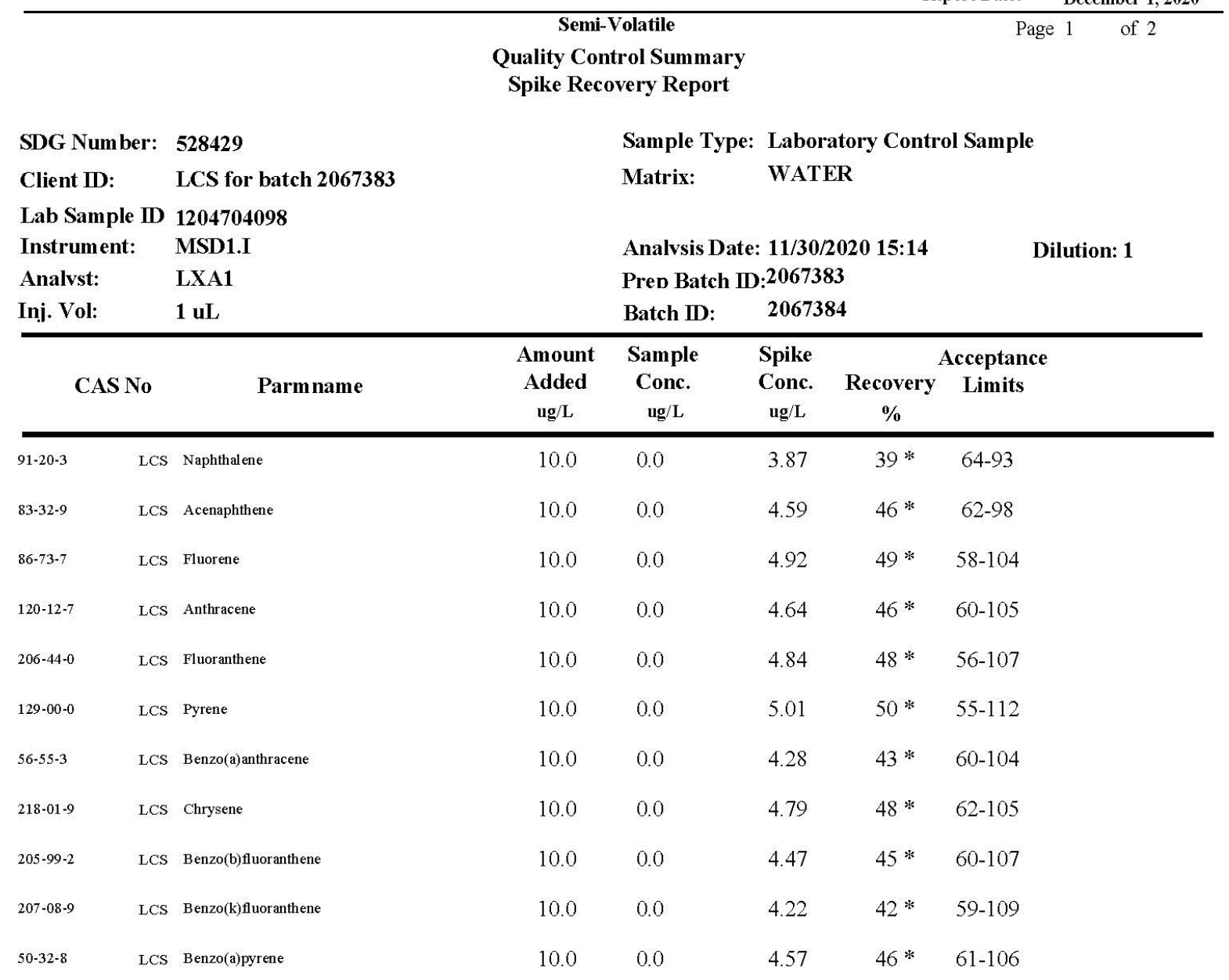




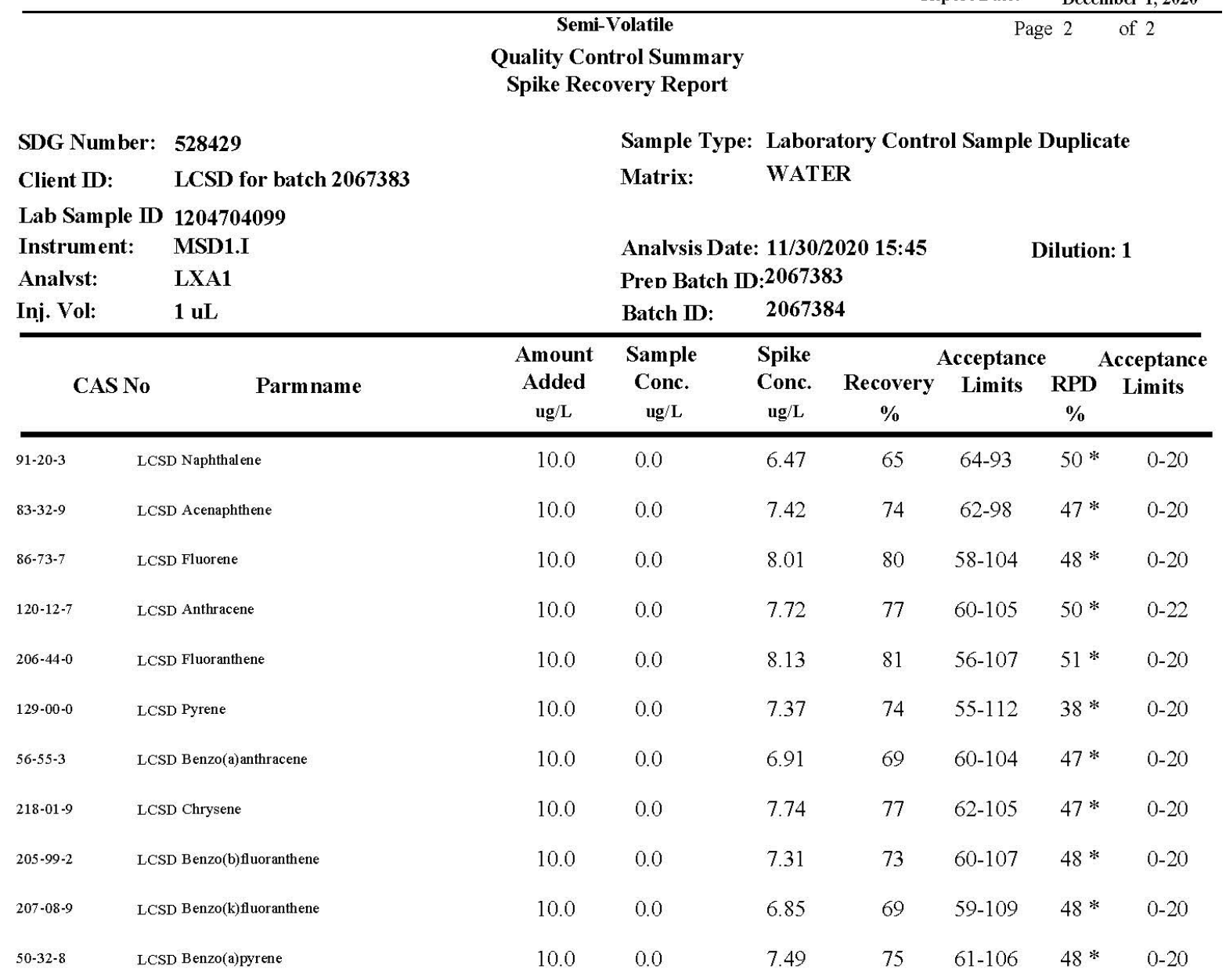


Method Blank Summary

$\begin{array}{ll}\text { SDG Number: } & 528429 \\ \text { Client ID: } & \text { MB for batch } 2067375 \\ \text { Lab Sample ID: } & 1204704080 \\ \text { Column: } & \text { Description: DB-5ms }\end{array}$

This method blank applies to the following samples and quality control samples:

$\begin{array}{ll}\text { Client: } & \text { MCOM001 } \\ \text { Instrument ID: } & \text { MSD1.I } \\ \text { Prep Date: } & \text { 11/30/2020 10:33 }\end{array}$

Prep Date:

Client Sample ID
01 LCS for batch 2067375
02 TANN20009
03 CV-SB-2E-1.0MS
04 CV-SB-2E-1.0MSD
05 TANN20006
06 TANN20007
07 TANN20008
08 TANN20010

Matrix: SOIL

Data File: $\quad$ s113020.B $\backslash \mathrm{s} 1 \mathrm{k} 3011 . \mathrm{D}$

Analyzed: $11 / 30 / 20$ 18:46
Page 1 of 1

\begin{tabular}{|c|c|}
\hline Lab Sample ID & File ID \\
\hline 1204704081 & $\mathrm{~s} 113020 . \mathrm{B} \backslash \mathrm{s} 1 \mathrm{k} 3012 . \mathrm{D}$ \\
\hline 528429005 & $\mathrm{~s} 113020 . \mathrm{B} \backslash \mathrm{s} 1 \mathrm{k} 3016 . \mathrm{D}$ \\
\hline 1204704082 & $\mathrm{~s} 113020 . \mathrm{B} \backslash \mathrm{s} 1 \mathrm{k} 3018 . \mathrm{D}$ \\
\hline 1204704083 & $\mathrm{~s} 113020 . \mathrm{B} \backslash \mathrm{s} 1 \mathrm{k} 3019 . \mathrm{D}$ \\
\hline 528429002 & $\mathrm{~s} 113020 . \mathrm{B} \backslash \mathrm{s} 1 \mathrm{k} 3021 . \mathrm{D}$ \\
\hline 528429003 & $\mathrm{~s} 113020 . \mathrm{B} \backslash \mathrm{s} 1 \mathrm{k} 3022 . \mathrm{D}$ \\
\hline 528429004 & $\mathrm{~s} 113020 . \mathrm{B} \backslash \mathrm{s} 1 \mathrm{k} 3023 . \mathrm{D}$ \\
\hline 528429006 & s120120.B $\backslash \mathrm{s} 1 \mathrm{~L} 0107 . \mathrm{D}$ \\
\hline
\end{tabular}

$\begin{array}{cc}\begin{array}{c}\text { Date Analyzed } \\ 11 / 30 / 20\end{array} & \begin{array}{c}\text { Time Analyzed } \\ 11 / 30 / 20\end{array} \\ 11 / 30 / 20 & 2124 \\ 11 / 30 / 20 & 2228 \\ 12 / 01 / 20 & 2300 \\ 12 / 01 / 20 & 0004 \\ 12 / 01 / 20 & 0037 \\ 12 / 01 / 20 & 0109 \\ \end{array}$

Page 112 of 151 SDG: 528429 
Method Blank Summary

$\begin{array}{ll}\text { SDG Number: } & 528429 \\ \text { Client ID: } & \text { MB for batch } 2067383 \\ \text { Lab Sample ID: } & 1204704097 \\ \text { Column: } & \text { Description: DB-5ms }\end{array}$

This method blank applies to the following samples and quality control samples:

\begin{abstract}
Client Sample ID
01 LCS for batch 2067383

02 LCSD for batch 2067383

03 FIELD BLANK
\end{abstract}

$\begin{array}{ll}\text { Client: } & \text { MCOM001 } \\ \text { Instrument ID: } & \text { MSD1.I } \\ \text { Prep Date: } & \mathbf{1 1 / 3 0 / 2 0 2 0 ~ 0 5 : 0 0}\end{array}$

Prep Date:

$\begin{array}{rc}\text { Lab Sample ID } & \text { File ID } \\ 1204704098 & \text { s113020.B } \backslash \text { s1k3005.D } \\ 1204704099 & \text { s113020.B } \backslash \text { s } 1 k 3006 . D \\ 528429001 & \text { s113020.B } \backslash s 1 \mathrm{k} 3007 . D\end{array}$

Matrix:

Data File:

Analyzed: $\quad 11 / 30 / 2017: 17$
Page 1 of 1

$\begin{array}{cc}\text { Date Analyzed } & \text { Time Analyzed } \\ 11 / 30 / 20 & 1514 \\ 11 / 30 / 20 & 1545 \\ 11 / 30 / 20 & 1617\end{array}$

Page 113 of 151 SDG: 528429 


\section{Instrument Performance Check}

DFTPP

Lab Name GEL Laboratories LLC

Instrument ID: MSD1.I

Column Description: Description: DB-5ms
Client SDG: 528429

Injection Date/Time: 17-NOV-20 12:07

\begin{tabular}{|c|c|c|}
\hline m/e & Ion Abundance Criteria & \% Relative Abundance \\
\hline 51 & $10-80 \%$ of mass 198 & 43 \\
\hline 68 & Less than $2 \%$ of mass 69 & 1.8 \\
\hline 69 & Mass 69 Relative Abundance & 44.6 \\
\hline 70 & Less than $2 \%$ of mass 69 & 0.4 \\
\hline 127 & $10-80 \%$ of mass 198 & 51.7 \\
\hline 197 & Less than $2 \%$ of mass 198 & 100 \\
\hline 198 & Base Peak, $100 \%$ Relative Abundance & 7.1 \\
\hline 199 & $5-9 \%$ of mass 198 & 29.5 \\
\hline 275 & $10-60 \%$ of mass 198 & 3.7 \\
\hline 365 & Greater than $1 \%$ of mass 198 & 15.1 \\
\hline 441 & Less than $24 \%$ of mass 442 & 86.5 \\
\hline 442 & Greater than $50 \%$ of mass 198 & 19.6 \\
\hline 443 & $15-24 \%$ of mass 442 & \\
\hline
\end{tabular}

THIS CHECK APPLIES TO THE FOLLOWING SAMPLES, MS, MSD, LCS, LCSD,BLANKS AND STANDARDS

\begin{tabular}{|c|c|c|c|}
\hline \begin{tabular}{|c|} 
Client \\
Sample ID \\
\end{tabular} & $\begin{array}{c}\text { Lab } \\
\text { Sample ID } \\
\end{array}$ & \begin{tabular}{|c|} 
Lab \\
File ID \\
\end{tabular} & \begin{tabular}{|c|} 
Time \\
Analyzed \\
\end{tabular} \\
\hline ICALMIX[A] & WBN200805-81 & s111720.B\s1k1702.D & 17-NOV-20 12:32 \\
\hline ICALMIX[A] & WBN200805-82 & s111720.B\s1k1703.D & 17-NOV-20 13:03 \\
\hline ICALMIX[A] & WBN200805-83 & s111720.B\s1k1704.D & 17-NOV-20 13:35 \\
\hline ICALMIX[A] & WBN200805-84 & s111720.B\s1k1705.D & 17-NOV-20 14:06 \\
\hline ICALMIX[A] & WBN200805-85 & s111720.B\s1k1706.D & 17-NOV-20 14:38 \\
\hline ICALMIX[A] & WBN200805-86.1 & s111720.B\s1k1707.D & 17-NOV-20 15:09 \\
\hline ICALMIX[A] & WBN200805-87 & s111720.Bls1k1708.D & 17-NOV-20 15:41 \\
\hline ICALMIX[A] & WBN200805-88 & s111720.B\s1k1709.D & 17-NOV-20 16:13 \\
\hline ICVMIX[A]01 & WBN200625-89 & s111720.B \s1k1710.D & 17-NOV-20 16:45 \\
\hline
\end{tabular}

Page 114 of 151 SDG: 528429 


\section{Instrument Performance Check}

DFTPP

Lab Name GEL Laboratories LLC

Instrument ID: MSD1.I

Column Description: Description: DB-5ms
Client SDG: 528429

Injection Date/Time: 30-NOV-20 13:18

Lab File ID s113020.B \s1k3001.D

\begin{tabular}{|c|c|c|}
\hline m/e & Ion Abundance Criteria & \% Relative Abundance \\
\hline 51 & $30-60 \%$ of mass 198 & 42.8 \\
\hline 68 & Less than $2 \%$ of mass 69 & 1.3 \\
\hline 69 & Mass 69 Relative Abundance & 44.2 \\
\hline 70 & Less than $2 \%$ of mass 69 & 0 \\
\hline 127 & $40-60 \%$ of mass 198 & 50.6 \\
\hline 197 & $0-1 \%$ of mass 198 & 0 \\
\hline 198 & Base Peak, $100 \%$ Relative Abundance & 6.7 \\
\hline 199 & $5-9 \%$ of mass 198 & 29.2 \\
\hline 275 & $10-30 \%$ of mass 198 & 3.5 \\
\hline 365 & Greater than $1 \%$ of mass 198 & 72.6 \\
\hline 441 & Present, but less than mass 443 & 87.4 \\
\hline 442 & Greater than $40 \%$ of mass 198 & 19.6 \\
\hline 443 & $17-23 \%$ of mass 442 & \\
\hline
\end{tabular}

THIS CHECK APPLIES TO THE FOLLOWING SAMPLES, MS, MSD, LCS, LCSD,BLANKS AND STANDARDS

\begin{tabular}{|c|c|c|c|}
\hline $\begin{array}{c}\text { Client } \\
\text { Sample ID }\end{array}$ & $\begin{array}{c}\text { Lab } \\
\text { Sample ID }\end{array}$ & $\begin{array}{c}\text { Lab } \\
\text { File ID }\end{array}$ & $\begin{array}{c}\text { Time } \\
\text { Analyzed }\end{array}$ \\
\hline CCV01 & WBN201120-86.4 & $\mathrm{s} 113020 . \mathrm{B} \backslash \mathrm{s} 1 \mathrm{k} 3002 . \mathrm{D}$ & 30-NOV-20 13:36 \\
\hline BLK01LCS & 1204704098 & s113020.B \s1k3005.D & 30-NOV-20 15:14 \\
\hline BLK01LCSD & 1204704099 & $\mathrm{~s} 113020 . \mathrm{B} \backslash \mathrm{s} 1 \mathrm{k} 3006 . \mathrm{D}$ & 30-NOV-20 15:45 \\
\hline FIELD BLANK & 528429001 & s113020.B \s1k3007.D & 30-NOV-20 16:17 \\
\hline BLK01 & 1204704097 & s113020.B \s1k3008.D & 30-NOV-20 17:17 \\
\hline
\end{tabular}

Page 115 of 151 SDG: 528429 


\section{Instrument Performance Check}

DFTPP

Lab Name GEL Laboratories LLC

Instrument ID: MSD1.I

Column Description: Description: DB-5ms
Client SDG: 528429

Injection Date/Time:30-NOV-20 17:47

\begin{tabular}{|c|c|c|}
\hline $\mathbf{m} / \mathbf{e}$ & Ion Abundance Criteria & \% Relative Abundance \\
\hline 51 & $10-80 \%$ of mass 198 & 37.4 \\
\hline 68 & Less than $2 \%$ of mass 69 & 0.9 \\
\hline 69 & Mass 69 Relative Abundance & 41 \\
\hline 70 & Less than $2 \%$ of mass 69 & 0.3 \\
\hline 127 & $10-80 \%$ of mass 198 & 49.1 \\
\hline 197 & Less than $2 \%$ of mass 198 & 0 \\
\hline 198 & Base Peak, $100 \%$ Relative Abundance & 90.9 \\
\hline 199 & $5-9 \%$ of mass 198 & 7.1 \\
\hline 275 & $10-60 \%$ of mass 198 & 40.8 \\
\hline 365 & Greater than $1 \%$ of mass 198 & 15.6 \\
\hline 441 & Less than $24 \%$ of mass 442 & 100 \\
\hline 442 & Greater than $50 \%$ of mass 198 & 19.1 \\
\hline 443 & $15-24 \%$ of mass 442 & \\
\hline
\end{tabular}

THIS CHECK APPLIES TO THE FOLLOWING SAMPLES, MS, MSD, LCS, LCSD,BLANKS AND STANDARDS

\begin{tabular}{|c|c|c|c|}
\hline $\begin{array}{c}\text { Client } \\
\text { Sample ID }\end{array}$ & $\begin{array}{c}\text { Lab } \\
\text { Sample ID }\end{array}$ & $\begin{array}{c}\text { Lab } \\
\text { File ID }\end{array}$ & $\begin{array}{c}\text { Time } \\
\text { Analyzed }\end{array}$ \\
\hline CCV02 & WBN201120-86.4 & s113020.B\s1k3010.D & 30-NOV-20 18:06 \\
\hline BLK02 & 1204704080 & s113020.B \s1k3011.D & 30-NOV-20 18:46 \\
\hline BLK02LCS & 1204704081 & $\mathrm{~s} 113020 . \mathrm{B} \backslash \mathrm{s} 1 \mathrm{k} 3012 . \mathrm{D}$ & 30-NOV-20 19:18 \\
\hline TANN20009 & 528429005 & s113020.B \s1k3016.D & 30-NOV-20 21:24 \\
\hline CV-SB-2E-1.0MS & 1204704082 & s113020.B \s1k3018.D & $30-N O V-2022: 28$ \\
\hline CV-SB-2E-1.0MSD & 1204704083 & s113020.B \s1k3019.D & 30-NOV-20 23:00 \\
\hline TANN20006 & 528429002 & s113020.B \s1k3021.D & 01-DEC-20 00:04 \\
\hline TANN20007 & 528429003 & s113020.B \s1k3022.D & 01-DEC-20 00:37 \\
\hline TANN20008 & 528429004 & s113020.Bls1k3023.D & 01-DEC-20 01:09 \\
\hline
\end{tabular}

Page 116 of 151 SDG: 528429 


\section{Instrument Performance Check}

DFTPP

Lab Name GEL Laboratories LLC

Instrument ID: MSD1.I

Column Description: Description: DB-5ms
Client SDG: 528429

Injection Date/Time: 01-DEC-20 12:10

\begin{tabular}{|c|c|c|}
\hline m/e & Ion Abundance Criteria & \% Relative Abundance \\
\hline 51 & $10-80 \%$ of mass 198 & 40.6 \\
\hline 68 & Less than $2 \%$ of mass 69 & 1.7 \\
\hline 69 & Mass 69 Relative Abundance & 41.3 \\
\hline 70 & Less than $2 \%$ of mass 69 & 0.3 \\
\hline 127 & $10-80 \%$ of mass 198 & 50.2 \\
\hline 197 & Less than $2 \%$ of mass 198 & 0 \\
\hline 198 & Base Peak, $100 \%$ Relative Abundance & 100 \\
\hline 199 & $5-9 \%$ of mass 198 & 6.7 \\
\hline 275 & $10-60 \%$ of mass 198 & 3.4 \\
\hline 365 & Greater than $1 \%$ of mass 198 & 14.2 \\
\hline 441 & Less than $24 \%$ of mass 442 & 95 \\
\hline 442 & Greater than $50 \%$ of mass 198 & 19.3 \\
\hline 443 & $15-24 \%$ of mass 442 & \\
\hline
\end{tabular}

THIS CHECK APPLIES TO THE FOLLOWING SAMPLES, MS, MSD, LCS, LCSD,BLANKS AND STANDARDS

\begin{tabular}{|c|c|c|c|}
\hline $\begin{array}{c}\text { Client } \\
\text { Sample ID }\end{array}$ & $\begin{array}{c}\text { Lab } \\
\text { Sample ID }\end{array}$ & $\begin{array}{c}\text { Lab } \\
\text { File ID }\end{array}$ & $\begin{array}{c}\text { Time } \\
\text { Analyzed }\end{array}$ \\
\hline CCV03 & WBN201120-82.1 & s120120.B\s1L0106.D & $01-D E C-2012: 32$ \\
\hline TANN20010 & 528429006 & s120120.B\s1L0107.D & 01-DEC-20 13:04 \\
\hline
\end{tabular}

Page 117 of $151 \quad$ SDG: 528429 


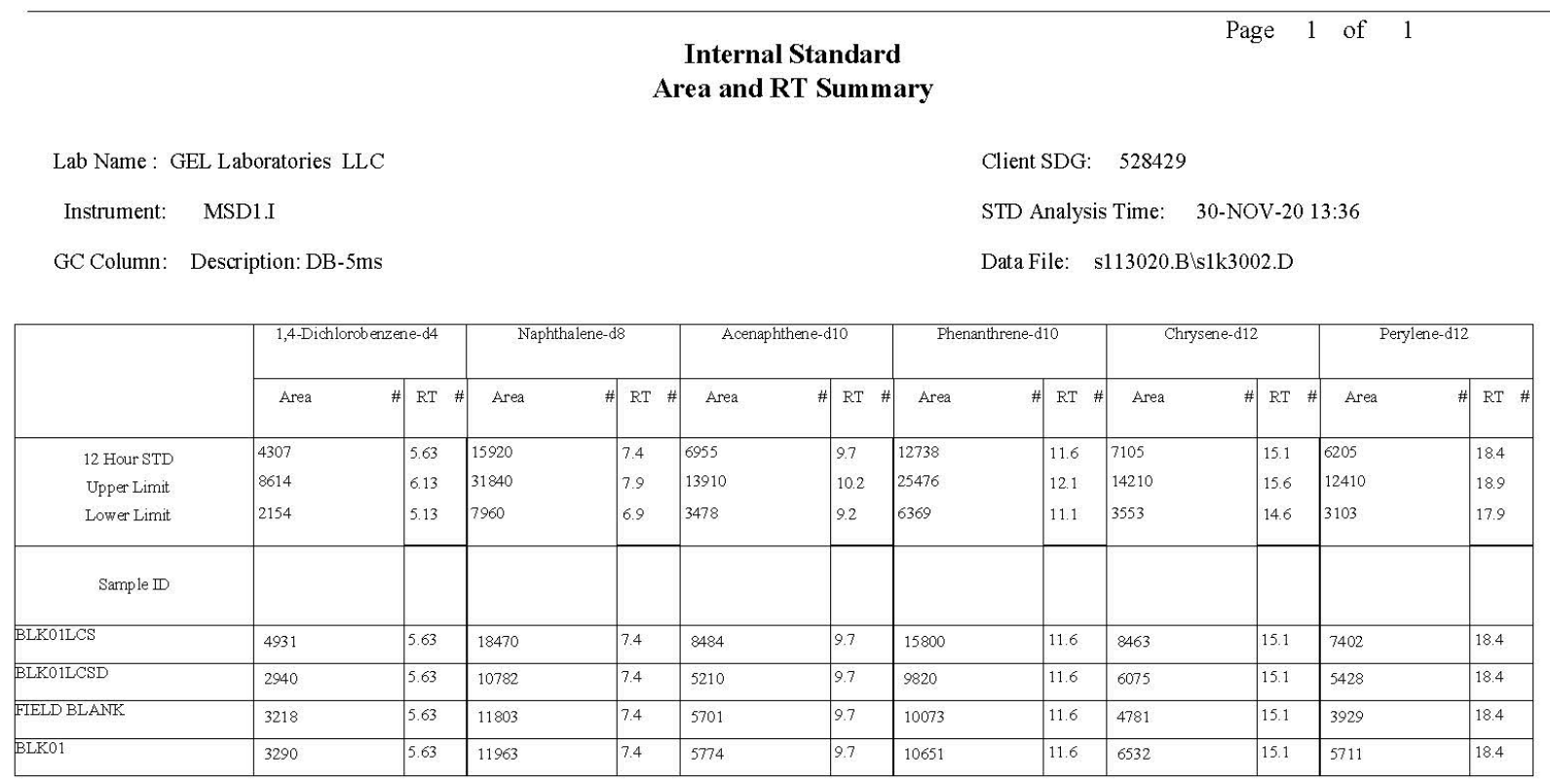

Area Upper Limit $=+100 \%$ of internal standard area Area Lower Limit $=-50 \%$ of internal standard area

RT Upper Limit $=+0.50$ minutes of internal standard RT RT Lower Limit $=-0.50$ minutes of internal standard RT

\# Column used to flag values outside QC limits with an asterisk

* Value outside of QC Limits

Page 118 of 151 SDG: 528429 


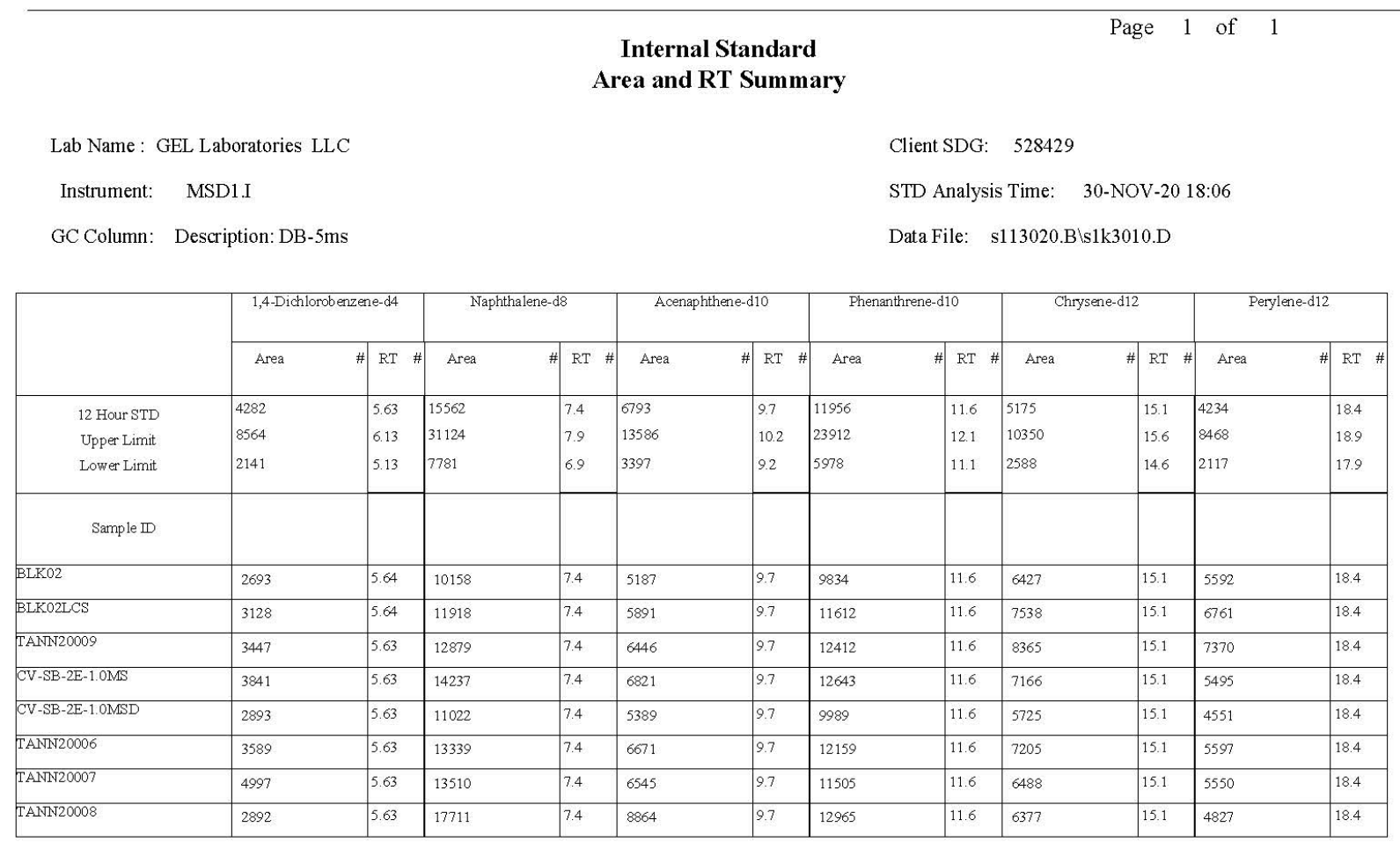

Area Upper Limit $=+100 \%$ of internal standard area

Area Lower Limit $=-50 \%$ of internal standard area

RT Upper Limit $=+0.50$ minutes of internal standard RT

RT Lower Limit $=-0.50$ minutes of internal standard RT

\# Column used to flag values outside QC limits with an asterisk

* Value outside of QC Limits

Page 119 of 151 SDG: 528429 


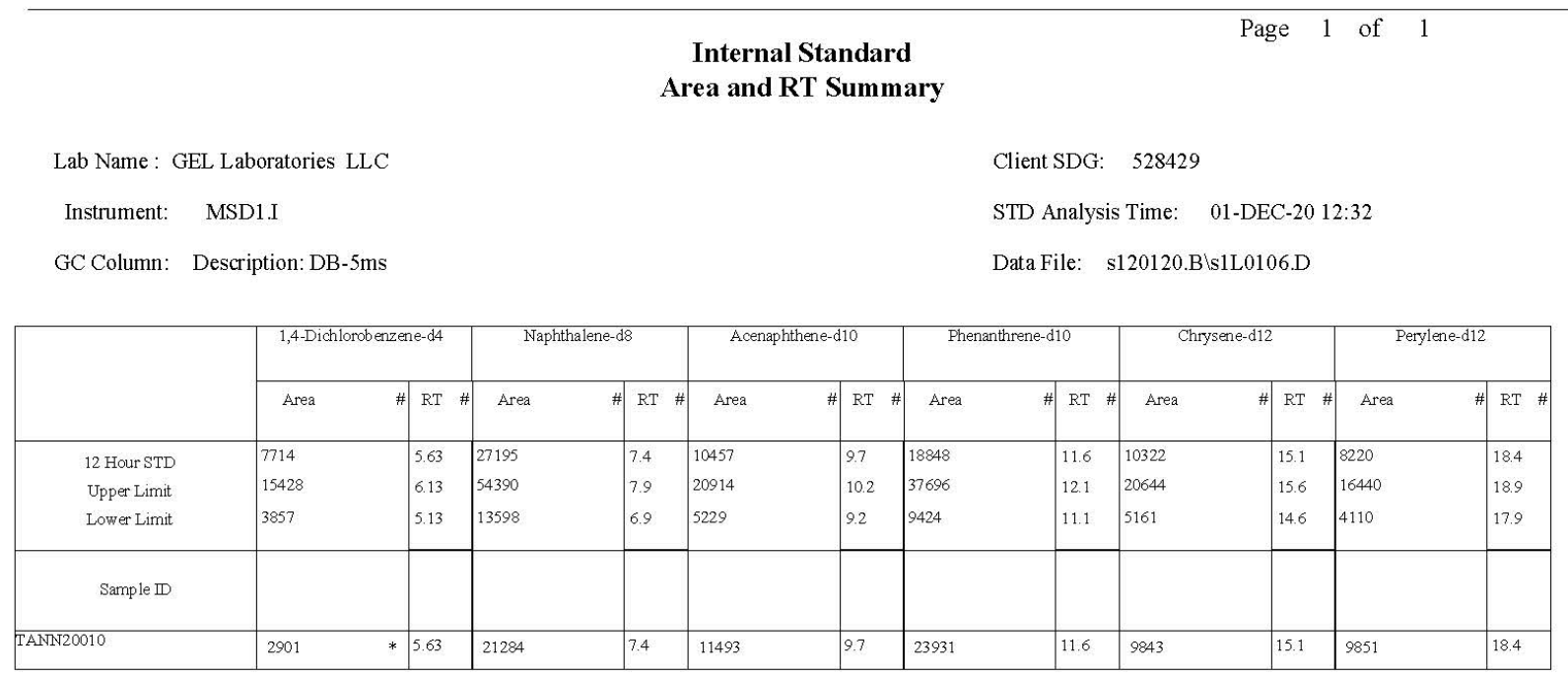

Area Upper Limit $=+100 \%$ of internal standard area

Area Lower Limit $=-50 \%$ of internal standard area

RT Upper Limit $=+0.50$ minutes of internal standard RT

RT Lower Limit $=-0.50$ minutes of internal standard RT

\# Column used to flag values outside $\mathrm{QC}$ limits with an asterisk

* Value outside of QC Limits

Page 120 of 151 SDG: 528429 


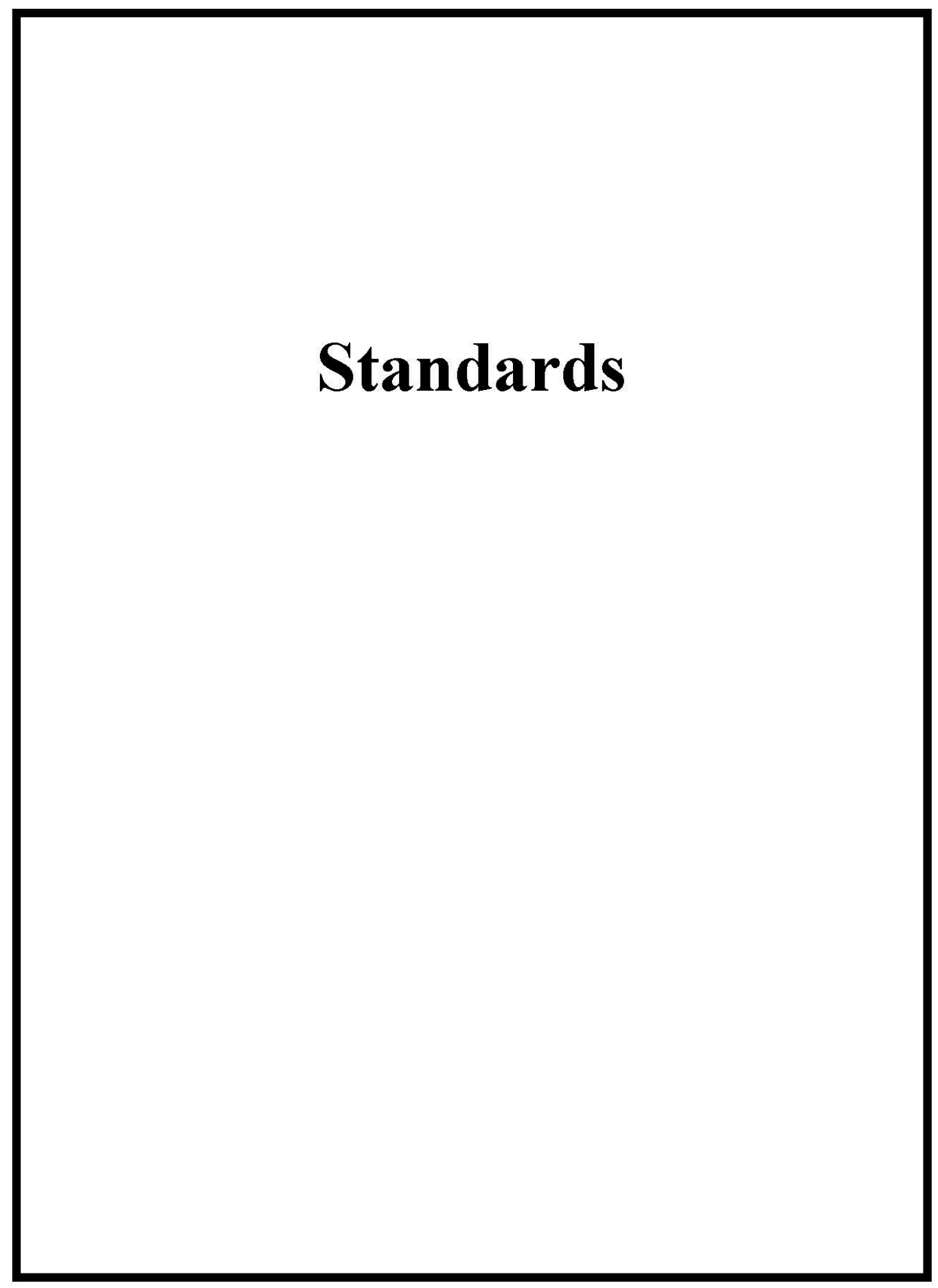

Page 121 of 151 SDG: 528429 


\begin{tabular}{|c|c|c|c|c|c|c|c|c|c|c|}
\hline SW846 8270/EPA 625 & & & & & & & & & & \\
\hline Calibration Standard Concentration Levels* & & & & & & & & & & \\
\hline MEGA MIX & Level 1 & Level 2 & Level3 & Level 4\# & Level 5 & Level 6 & Level 7 & Level 8 & Level 9 & Level 10 \\
\hline 1,4-Dichlorobenzene-d4 (INTERNAL STANDARE & & & & & & & & & & \\
\hline Naphthalene-d8 (INTERNAL STANDARD) & & & & & & & & & & \\
\hline Acenaphthene-d10 (INTERNAL STANDARD) & & & & & & & & & & \\
\hline Phenanthrene-d10 (NTERNAL STANDARD) & & & & & & & & & & \\
\hline Chrysene-d12 (INTERNAL ST ANDARD) & & & & & & & & & & \\
\hline Perylene-d12 (NTERNAL STANDARD) & & & & & & & & & & \\
\hline 2-Fluorophenol (SURROGATE) & & 10 & 20 & 40 & 50 & 80 & 100 & 120 & 30 & 60 \\
\hline Phenol-d5 (SURROGATE) & & 10 & 20 & 40 & 50 & 80 & 100 & 120 & 30 & 60 \\
\hline 2-Chlorophenol-d4 (CLP SURROGATE) & & 10 & 20 & 40 & 50 & 80 & 100 & 120 & 30 & 60 \\
\hline 1,2-Dichlorobenzene-d4 (CLP SURROGATE) & & 10 & 20 & 40 & 50 & 80 & 100 & 120 & 30 & 60 \\
\hline Nitrobenzene-d5 (SURROGATE) & & 10 & 20 & 40 & 50 & 80 & 100 & 120 & 30 & 60 \\
\hline 2-Fluorobiphenyl (SURROGATE) & & 10 & 20 & 40 & 50 & 80 & 100 & 120 & 30 & 60 \\
\hline 2,4,6-Tribromophenol (SURROGATE) & & 10 & 20 & 40 & 50 & 80 & 100 & 120 & 30 & 60 \\
\hline p-Terphenyl-d14 (SURROGATE) & & 10 & 20 & 40 & 50 & 80 & 100 & 120 & 30 & 60 \\
\hline N-Nitrosodimethylamine & $1^{\star *}$ & 10 & 20 & 40 & 50 & 80 & 100 & 120 & 30 & 60 \\
\hline Pyridine & & 10 & 20 & 40 & 50 & 80 & 100 & 120 & 30 & 60 \\
\hline Aniline & & 10 & 20 & 40 & 50 & 80 & 100 & 120 & 30 & 60 \\
\hline Phenol & & 10 & 20 & 40 & 50 & 80 & 100 & 120 & 30 & 60 \\
\hline bis(2-Chloroethyl)ether & & 10 & 20 & 40 & 50 & 80 & 100 & 120 & 30 & 60 \\
\hline 2-Chlorophenol & & 10 & 20 & 40 & 50 & 80 & 100 & 120 & 30 & 60 \\
\hline n-Decane & & 10 & 20 & 40 & 50 & 80 & 100 & 120 & 30 & 60 \\
\hline 1,3-Dichlorobenzene & & 10 & 20 & 40 & 50 & 80 & 100 & 120 & 30 & 60 \\
\hline 1,4-Dichlorobenzene & & 10 & 20 & 40 & 50 & 80 & 100 & 120 & 30 & 60 \\
\hline Benzyl Alcohol & & 10 & 20 & 40 & 50 & 80 & 100 & 120 & 30 & 60 \\
\hline 1,2-Dichlorobenzene & & 10 & 20 & 40 & 50 & 80 & 100 & 120 & 30 & 60 \\
\hline bis(2-Chloro-1-methylethyl)ether & & 10 & 20 & 40 & 50 & 80 & 100 & 120 & 30 & 60 \\
\hline o-Cresol (2-Methylphenol) & & 10 & 20 & 40 & 50 & 80 & 100 & 120 & 30 & 60 \\
\hline N-Nitrosodipropylamine & & 10 & 20 & 40 & 50 & 80 & 100 & 120 & 30 & 60 \\
\hline m,p-Cresols (3-Methylphenol \& 4-Methylphenol) & & 10 & 20 & 40 & 50 & 80 & 100 & 120 & 30 & 60 \\
\hline Hexachloroethane & & 10 & 20 & 40 & 50 & 80 & 100 & 120 & 30 & 60 \\
\hline Nitrobenzene & & 10 & 20 & 40 & 50 & 80 & 100 & 120 & 30 & 60 \\
\hline Isophorone & & 10 & 20 & 40 & 50 & 80 & 100 & 120 & 30 & 60 \\
\hline 2-Nitrophenol & & 10 & 20 & 40 & 50 & 80 & 100 & 120 & 30 & 60 \\
\hline 2,4-Dimethylphenol & & 10 & 20 & 40 & 50 & 80 & 100 & 120 & 30 & 60 \\
\hline bis(2-Chloroethoxy)methane & & 10 & 20 & 40 & 50 & 80 & 100 & 120 & 30 & 60 \\
\hline 2,4-Dichlorophenol & & 10 & 20 & 40 & 50 & 80 & 100 & 120 & 30 & 60 \\
\hline Benzoic Acid & & & 20 & 40 & 50 & 80 & 100 & 120 & 30 & 60 \\
\hline 1,2,4-Trichlorobenzene & & 10 & 20 & 40 & 50 & 80 & 100 & 120 & 30 & 60 \\
\hline Naphthalene & 1 & 10 & 20 & 40 & 50 & 80 & 100 & 120 & 30 & 60 \\
\hline alpha-Terpineol & & 10 & 20 & 40 & 50 & 80 & 100 & 120 & 30 & 60 \\
\hline 4-Chloroaniline & & 10 & 20 & 40 & 50 & 80 & 100 & 120 & 30 & 60 \\
\hline
\end{tabular}

Page 122 of 151 SDG: 528429 


\begin{tabular}{|c|c|c|c|c|c|c|c|c|c|c|}
\hline SW846 8270/EPA 625 & & & & & & & & & & \\
\hline Calibration Standard Concentration Levels* & & & & & & & & & & \\
\hline MEGA MIX & Level 1 & Level 2 & Level 3 & Level 4\# & Level 5 & Level 6 & Level 7 & Level 8 & Level 9 & Level 10 \\
\hline Hexachlorobutadiene & & 10 & 20 & 40 & 50 & 80 & 100 & 120 & 30 & 60 \\
\hline 4-Chloro-3-methylphenol & & 10 & 20 & 40 & 50 & 80 & 100 & 120 & 30 & 60 \\
\hline 2-Methylnaphthalene & 1 & 10 & 20 & 40 & 50 & 80 & 100 & 120 & 30 & 60 \\
\hline 1-Methylnaphthalene & $\overline{1}$ & 10 & 20 & 40 & 50 & 80 & 100 & 120 & 30 & 60 \\
\hline Hexachlorocyclopentadiene & & 10 & 20 & 40 & 50 & 80 & 100 & 120 & 30 & 60 \\
\hline 2,3-Dichloroaniline & & 10 & 20 & 40 & 50 & 80 & 100 & 120 & 30 & 60 \\
\hline 2,4,6-Trichlorophenol & & 10 & 20 & 40 & 50 & 80 & 100 & 120 & 30 & 60 \\
\hline 2,4,5-Trichlorophenol & & 10 & 20 & 40 & 50 & 80 & 100 & 120 & 30 & 60 \\
\hline 2-Chloronaphthalene & 1 & 10 & 20 & 40 & 50 & 80 & 100 & 120 & 30 & 60 \\
\hline o-Nitroaniline & & 10 & 20 & 40 & 50 & 80 & 100 & 120 & 30 & 60 \\
\hline m-Nitroaniline & & 10 & 20 & 40 & 50 & 80 & 100 & 120 & 30 & 60 \\
\hline Dimethylphthalate & $1^{\star \star}$ & 10 & 20 & 40 & 50 & 80 & 100 & 120 & 30 & 60 \\
\hline 2,6-Dinitrotoluene & & 10 & 20 & 40 & 50 & 80 & 100 & 120 & 30 & 60 \\
\hline Acenaphthylene & 1 & 10 & 20 & 40 & 50 & 80 & 100 & 120 & 30 & 60 \\
\hline Acenaphthene & 1 & 10 & 20 & 40 & 50 & 80 & 100 & 120 & 30 & 60 \\
\hline 2,4-Dinitrophenol & & & 20 & 40 & 50 & 80 & 100 & 120 & 30 & 60 \\
\hline Dibenzofuran & & 10 & 20 & 40 & 50 & 80 & 100 & 120 & 30 & 60 \\
\hline 2,4-Dinitrotoluene & & 10 & 20 & 40 & 50 & 80 & 100 & 120 & 30 & 60 \\
\hline Diethylphthalate & $1^{\star \star}$ & 10 & 20 & 40 & 50 & 80 & 100 & 120 & 30 & 60 \\
\hline 4-Nitrophenol & & 10 & 20 & 40 & 50 & 80 & 100 & 120 & 30 & 60 \\
\hline Fluorene & 1 & 10 & 20 & 40 & 50 & 80 & 100 & 120 & 30 & 60 \\
\hline 4-Chlorophenyl phenyl ether & & 10 & 20 & 40 & 50 & 80 & 100 & 120 & 30 & 60 \\
\hline 2-Methyl-4,6-dinitrophenol & & 10 & 20 & 40 & 50 & 80 & 100 & 120 & 30 & 60 \\
\hline p-Nitroaniline & & 10 & 20 & 40 & 50 & 80 & 100 & 120 & 30 & 60 \\
\hline Diphenylamine & & 10 & 20 & 40 & 50 & 80 & 100 & 120 & 30 & 60 \\
\hline 1,2-Diphenylhydrazine & & 10 & 20 & 40 & 50 & 80 & 100 & 120 & 30 & 60 \\
\hline 4-Bromophenyl phenyether & & 10 & 20 & 40 & 50 & 80 & 100 & 120 & 30 & 60 \\
\hline Hexachlorobenzene & & 10 & 20 & 40 & 50 & 80 & 100 & 120 & 30 & 60 \\
\hline Pentachlorophenol & & 10 & 20 & 40 & 50 & 80 & 100 & 120 & 30 & 60 \\
\hline n-Octadecane & & 10 & 20 & 40 & 50 & 80 & 100 & 120 & 30 & 60 \\
\hline Phenanthrene & 1 & 10 & 20 & 40 & 50 & 80 & 100 & 120 & 30 & 60 \\
\hline Anthracene & 1 & 10 & 20 & 40 & 50 & 80 & 100 & 120 & 30 & 60 \\
\hline Di-n-butylphthalate & $1^{\star \star}$ & 10 & 20 & 40 & 50 & 80 & 100 & 120 & 30 & 60 \\
\hline Fluoranthene & 1 & 10 & 20 & 40 & 50 & 80 & 100 & 120 & 30 & 60 \\
\hline Pyrene & 1 & 10 & 20 & 40 & 50 & 80 & 100 & 120 & 30 & 60 \\
\hline Butylbenzylphthalate & $1^{\star \star}$ & 10 & 20 & 40 & 50 & 80 & 100 & 120 & 30 & 60 \\
\hline Benzo(a)anthracene & 1 & 10 & 20 & 40 & 50 & 80 & 100 & 120 & 30 & 60 \\
\hline Chrysene & 1 & 10 & 20 & 40 & 50 & 80 & 100 & 120 & 30 & 60 \\
\hline bis (2-Ethylhexyl) phthalate & 1 & 10 & 20 & 40 & 50 & 80 & 100 & 120 & 30 & 60 \\
\hline Di-n-octylphthalate & $1^{\star \star}$ & 10 & 20 & 40 & 50 & 80 & 100 & 120 & 30 & 60 \\
\hline
\end{tabular}

Page 123 of 151 SDG: 528429 


\begin{tabular}{|c|c|c|c|c|c|c|c|c|c|c|}
\hline \multirow{2}{*}{\multicolumn{11}{|c|}{$\begin{array}{l}\text { SW846 8270/EPA } 625 \\
\text { Calibration Standard Concentration Levels* }\end{array}$}} \\
\hline & & & & & & & & & & \\
\hline MEGA MIX & Level 1 & Level 2 & Level 3 & Level 4\# & Level 5 & Level 6 & Level 7 & Level 8 & Level 9 & Level 10 \\
\hline Benzo(b)fluoranthene & 1 & 10 & 20 & 40 & 50 & 80 & 100 & 120 & 30 & 60 \\
\hline Benzo(k)fluoranthene & 1 & 10 & 20 & 40 & 50 & 80 & 100 & 120 & 30 & 60 \\
\hline Benzo(a)pyrene & 1 & 10 & 20 & 40 & 50 & 80 & 100 & 120 & 30 & 60 \\
\hline Indeno-(1,2,3-cd)pyrene & 1 & 10 & 20 & 40 & 50 & 80 & 100 & 120 & 30 & 60 \\
\hline Dibenzo(a,h)anthracene & 1 & 10 & 20 & 40 & 50 & 80 & 100 & 120 & 30 & 60 \\
\hline Benzo(ghi)perylene & 1 & 10 & 20 & 40 & 50 & 80 & 100 & 120 & 30 & 60 \\
\hline m-Dinitrobenzene & & 10 & 20 & 40 & 50 & 80 & 100 & 120 & 30 & 60 \\
\hline 2,3,4,6-Tetrachlorophenol & & 10 & 20 & 40 & 50 & 80 & 100 & 120 & 30 & 60 \\
\hline Dinoseb & & 10 & 20 & 40 & 50 & 80 & 100 & 120 & 30 & 60 \\
\hline Carbazole & 1 & 10 & 20 & 40 & 50 & 80 & 100 & 120 & 30 & 60 \\
\hline p-Benzoquinone & & 10 & 20 & 40 & 50 & 80 & 100 & 120 & 30 & 60 \\
\hline Methoxychlor & & 10 & 20 & 40 & 50 & 80 & 100 & 120 & 30 & 60 \\
\hline p-Toluidine & & 10 & 20 & 40 & 50 & 80 & 100 & 120 & 30 & 60 \\
\hline m-Toluidine & & 10 & 20 & 40 & 50 & 80 & 10 & 120 & 30 & 60 \\
\hline 1,4-Dinitrobenzene & & 10 & 20 & 40 & 50 & 80 & 100 & 120 & 30 & 60 \\
\hline 2-Ethoxyethanol & & 10 & 20 & 40 & 50 & 80 & 100 & 120 & 30 & 60 \\
\hline Phthalic anhydride & & 10 & 20 & 40 & 50 & 80 & 100 & 120 & 30 & 60 \\
\hline Methylenebis(2-chloroaniline) & & 10 & 20 & 40 & 50 & 80 & 100 & 120 & 30 & 60 \\
\hline Dibenzo(a,e)pyrene & & 10 & 20 & 40 & 50 & 80 & 100 & 120 & 30 & 60 \\
\hline
\end{tabular}

\begin{tabular}{|c|c|c|c|c|c|c|c|c|c|c|}
\hline SW846 8270/EPA 625 & & & & & & & & & & \\
\hline Calibration Standard Concentration Levels* & & & & & & & & & & \\
\hline $\mathrm{AP} \mathrm{MIX}$ & Level 1 & Level 2 & Level 3 & Level 4\# & Level 5 & Level 6 & Level 7 & Level 8 & Level 9 & Level 10 \\
\hline Benzaldehyde & & 10 & 20 & 40 & 50 & 80 & 100 & 120 & 30 & 60 \\
\hline Acetophenone & & 10 & 20 & 40 & 50 & 80 & 100 & 120 & 30 & 60 \\
\hline Caprolactam & & 10 & 20 & 40 & 50 & 80 & 100 & 120 & 30 & 60 \\
\hline 1,1'-Biphenyl & & 10 & 20 & 40 & 50 & 80 & 100 & 120 & 30 & 60 \\
\hline Atrazine & & 10 & 20 & 40 & 50 & 80 & 100 & 120 & 30 & 60 \\
\hline Benzidine & & 10 & 20 & 40 & 50 & 80 & 100 & 120 & 30 & 60 \\
\hline 3,3'-Dichlorobenzidene & & 10 & 20 & 40 & 50 & 80 & 100 & 120 & 30 & 60 \\
\hline 1,4-Dioxane & & 10 & 20 & 40 & 50 & 80 & 100 & 120 & 30 & 60 \\
\hline Methyl methacrylate & & 10 & 20 & 40 & 50 & 80 & 100 & 120 & 30 & 60 \\
\hline Ethyl methacrylate & & 10 & 20 & 40 & 50 & 80 & 100 & 120 & 30 & 60 \\
\hline 2-Picoline & & 10 & 20 & 40 & 50 & 80 & 100 & 120 & 30 & 60 \\
\hline N-Nitrosomethylethylamine & & 10 & 20 & 40 & 50 & 80 & 100 & 120 & 30 & 60 \\
\hline 2-Butoxyethanol & & 10 & 20 & 40 & 50 & 80 & 100 & 120 & 30 & 60 \\
\hline Methyl methanesulfonate & & 10 & 20 & 40 & 50 & 80 & 100 & 120 & 30 & 60 \\
\hline N-Nitrosodiethylamine & & 10 & 20 & 40 & 50 & 80 & 100 & 120 & 30 & 60 \\
\hline Ethyl methanesulfonate & & 10 & 20 & 40 & 50 & 80 & 100 & 120 & 30 & 60 \\
\hline Pentachloroethane & & 10 & 20 & 40 & 50 & 80 & 100 & 120 & 30 & 60 \\
\hline N-Nitrosopyrrolidine & & 10 & 20 & 40 & 50 & 80 & 100 & 120 & 30 & 60 \\
\hline N-Nitrosomorpholine & & 10 & 20 & 40 & 50 & 80 & 100 & 120 & 30 & 60 \\
\hline o-Toluidine & & 10 & 20 & 40 & 50 & 80 & 100 & 120 & 30 & 60 \\
\hline N-Nitrosopiperidine & & 10 & 20 & 40 & 50 & 80 & 100 & 120 & 30 & 60 \\
\hline a, a-Dimethylphenethylamine & & 10 & 20 & 40 & 50 & 80 & 100 & 120 & 30 & 60 \\
\hline 2,6-Dichlorophenol & & 10 & 20 & 40 & 50 & 80 & 100 & 120 & 30 & 60 \\
\hline
\end{tabular}

Page 124 of 151 SDG: 528429 


\begin{tabular}{|c|c|c|c|c|c|c|c|c|c|c|}
\hline SW846 8270/EPA 625 & & & & & & & & & & \\
\hline Calibration Standard Concentration Levels* & & & & & & & & & & \\
\hline $\mathrm{AP} \mathrm{MIX}$ & Level 1 & Level 2 & Level 3 & Level 4\# & Level 5 & Level 6 & Level 7 & Level 8 & Level 9 & Level 10 \\
\hline Hexachloropropene & & 10 & 20 & 40 & 50 & 80 & 100 & 120 & 30 & 60 \\
\hline N-Nitrosodi-n-butylamine & & 10 & 20 & 40 & 50 & 80 & 100 & 120 & 30 & 60 \\
\hline Safrole & & 10 & 20 & 40 & 50 & 80 & 100 & 120 & 30 & 60 \\
\hline 1,2,4,5-Tetrachlorobenzene & & 10 & 20 & 40 & 50 & 80 & 100 & 120 & 30 & 60 \\
\hline Isosafrole & & 10 & 20 & 40 & 50 & 80 & 100 & 120 & 30 & 60 \\
\hline 1,4-Naphthoquinone & & 10 & 20 & 40 & 50 & 80 & 100 & 120 & 30 & 60 \\
\hline Pentachlorobenzene & & 10 & 20 & 40 & 50 & 80 & 100 & 120 & 30 & 60 \\
\hline 1-Naphthylamine & & 10 & 20 & 40 & 50 & 80 & 100 & 120 & 30 & 60 \\
\hline 2-Naphthylamine & & 10 & 20 & 40 & 50 & 80 & 100 & 120 & 30 & 60 \\
\hline 5-Nitro-o-toluidine & & 10 & 20 & 40 & 50 & 80 & 100 & 120 & 30 & 60 \\
\hline 1,3,5-Trinitrobenzene & & 10 & 20 & 40 & 50 & 80 & 100 & 120 & 30 & 60 \\
\hline Phenacetin & & 10 & 20 & 40 & 50 & 80 & 100 & 120 & 30 & 60 \\
\hline Diallate & & 10 & 20 & 40 & 50 & 80 & 100 & 120 & 30 & 60 \\
\hline cis-Diallate & & 1.5 & 3 & 6 & 7.5 & 12 & 15 & 18 & 4.5 & 9 \\
\hline trans-Diallate & & 8.5 & 17 & 34 & 42 & 68 & 85 & 102 & 25.5 & 51 \\
\hline 4-Aminobiphenyl & & 10 & 20 & 40 & 50 & 80 & 100 & 120 & 30 & 60 \\
\hline Pentachloronitrobenzene & & 10 & 20 & 40 & 50 & 80 & 100 & 120 & 30 & 60 \\
\hline Pronamide & & 10 & 20 & 40 & 50 & 80 & 100 & 120 & 30 & 60 \\
\hline 4-Nitroquinoline-1-oxide & & 10 & 20 & 40 & 50 & 80 & 100 & 120 & 30 & 60 \\
\hline Methapyrilene & & 10 & 20 & 40 & 50 & 80 & 100 & 120 & 30 & 60 \\
\hline Isodrin & & 10 & 20 & 40 & 50 & 80 & 100 & 120 & 30 & 60 \\
\hline Aramite & & 10 & 20 & 40 & 50 & 80 & 100 & 120 & 30 & 60 \\
\hline Kepone & & 10 & 20 & 40 & 50 & 80 & 100 & 120 & 30 & 60 \\
\hline p-(Dimethylamino)azobenzene & & 10 & 20 & 40 & 50 & 80 & 100 & 120 & 30 & 60 \\
\hline Chlorobenzilate & & 10 & 20 & 40 & 50 & 80 & 100 & 120 & 30 & 60 \\
\hline 3,3'-Dimethylbenzidine & & 10 & 20 & 40 & 50 & 80 & 100 & 120 & 30 & 60 \\
\hline 2-Acetylaminofluorene & & 10 & 20 & 40 & 50 & 80 & 100 & 120 & 30 & 60 \\
\hline 7,12-Dimethylbenz(a)anthracene & & 10 & 20 & 40 & 50 & 80 & 100 & 120 & 30 & 60 \\
\hline 3-Methylcholanthrene & & 10 & 20 & 40 & 50 & 80 & 100 & 120 & 30 & 60 \\
\hline
\end{tabular}

\begin{tabular}{|c|c|c|c|c|c|c|c|c|c|c|}
\hline SW846 8270/EPA 625 & & & & & & & & & & \\
\hline Calibration Standard Concentration Levels ${ }^{*}$ & & & & & & & & & & \\
\hline & Level 1 & Level 2 & Level 3 & Level 4f & Level 5 & Level 6 & Level 7 & Level 8 & Level 9 & Level 10 \\
\hline Hexachlorophene & & 500 & 1000 & 1250 & 1500 & 1750 & 2000 & & & \\
\hline p-Phenylenediamine & & 500 & 1000 & 1250 & 1500 & 1750 & 2000 & & & \\
\hline
\end{tabular}

Page 125 of 151 SDG: 528429 


\begin{tabular}{|c|c|c|c|c|c|c|c|c|c|c|}
\hline \multirow{2}{*}{$\begin{array}{l}\text { SW846 8270/EPA } 625 \\
\text { Calibration Standard Concentration Levels* }\end{array}$} & & & & & & & & & & \\
\hline & & & & & & & & & & \\
\hline PEST MIX & Level 1 & Level 2 & Level3 & Level 4\# & Level 5 & Level 6 & Level 7 & Level 8 & Level 9 & Level 10 \\
\hline bis(Chloromethyl)ether & & 10 & 20 & 40 & 50 & 80 & 100 & 120 & 30 & 60 \\
\hline Tributylphosphate & & 10 & 20 & 40 & 50 & 80 & 100 & 120 & 30 & 60 \\
\hline Triethylphosphorothioate & & 10 & 20 & 40 & 50 & 80 & 100 & 120 & 30 & 60 \\
\hline Thionazin & & 10 & 20 & 40 & 50 & 80 & 100 & 120 & 30 & 60 \\
\hline Sulfotepp & & 10 & 20 & 40 & 50 & 80 & 100 & 120 & 30 & 60 \\
\hline Phorate & & 10 & 20 & 40 & 50 & 80 & 100 & 120 & 30 & 60 \\
\hline Dimethoate & & 10 & 20 & 40 & 50 & 80 & 100 & 120 & 30 & 60 \\
\hline Disulfoton & & 10 & 20 & 40 & 50 & 80 & 100 & 120 & 30 & 60 \\
\hline Methyl parathion & & 10 & 20 & 40 & 50 & 80 & 100 & 120 & 30 & 60 \\
\hline Famphur & & 10 & 20 & 40 & 50 & 80 & 100 & 120 & 30 & 60 \\
\hline Parathion & & 10 & 20 & 40 & 50 & 80 & 100 & 120 & 30 & 60 \\
\hline
\end{tabular}

\begin{tabular}{|c|c|c|c|c|c|c|c|c|c|c|}
\hline \multirow{2}{*}{$\begin{array}{l}\text { SW846 8270/EPA } 625 \\
\text { Calibration Standard Concentration Levels* }\end{array}$} & \multirow[b]{3}{*}{ Level 1} & \multirow[b]{3}{*}{ Level 2} & \multirow[b]{3}{*}{ Level 3} & \multirow[b]{3}{*}{ Level 4\# } & \multirow[b]{3}{*}{ Level 5} & \multirow[b]{3}{*}{ Level 6} & \multirow[b]{3}{*}{ Level 7} & \multirow[b]{3}{*}{ Level 8} & \multirow[b]{3}{*}{ Level 9} & \multirow[b]{3}{*}{ Level 10} \\
\hline & & & & & & & & & & \\
\hline NEVADA MIX & & & & & & & & & & \\
\hline bis(Chloromethyl)ether & & 10 & 20 & 40 & 50 & 80 & 100 & 120 & 30 & 60 \\
\hline 4-Chlorothiophenol & & 10 & 20 & 40 & 50 & 80 & 100 & 120 & 30 & 60 \\
\hline 4-Chlorothioanisole & & 10 & 20 & 40 & 50 & 80 & 100 & 120 & 30 & 60 \\
\hline Phthalic acid & & 10 & 20 & 40 & 50 & 80 & 100 & 120 & 30 & 60 \\
\hline Hydroxymethyl phthalimide & & 10 & 20 & 40 & 50 & 80 & 100 & 120 & 30 & 60 \\
\hline Diphenyl sulfide & & 10 & 20 & 40 & 50 & 80 & 100 & 120 & 30 & 60 \\
\hline Diphenyl disulfide & & 10 & 20 & 40 & 50 & 80 & 100 & 120 & 30 & 60 \\
\hline Phenyl sulfone & & 10 & 20 & 40 & 50 & 80 & 100 & 120 & 30 & 60 \\
\hline Octachlorostyrene & & 10 & 20 & 40 & 50 & 80 & 100 & 120 & 30 & 60 \\
\hline Thiophenol & & 10 & 20 & 40 & 50 & 80 & 100 & 120 & 30 & 60 \\
\hline 2,2'-Dichlorobenzil & & 10 & 20 & 40 & 50 & 80 & 100 & 120 & 30 & 60 \\
\hline bis(p-Chlorophenyl)disulfide & & 10 & 20 & 40 & 50 & 80 & 100 & 120 & 30 & 60 \\
\hline bis $(p-C h l o r o p h e n y l)$ sulfone & & 10 & 20 & 40 & 50 & 80 & 100 & 120 & 30 & 60 \\
\hline
\end{tabular}

All values are $\mathrm{mg} / \mathrm{L}$ without the prep factor.

\# Indicates the calibration verification concentration level used

* Usual calibration levels using SCAN methodology

** This analyte included in this level at special client request.

\begin{tabular}{|c|c|c|c|c|c|c|c|c|}
\hline \multirow{2}{*}{\multicolumn{9}{|c|}{$\begin{array}{l}\text { EPA } 522 \\
\text { Calibration Standard Concentration Levels\# }\end{array}$}} \\
\hline & & & & & & & & \\
\hline & Level 1 & Level 2 & Level 3 & Level 4 & Level 5 & $\mathrm{ICV}$ & $\mathrm{CCV}$ & \\
\hline \multicolumn{9}{|c|}{ Tetrahydrofuran-d8 (INTERNAL STANDARD) } \\
\hline 1,4-Dioxane-d8 (SURROGATE) & 50 & 100 & 200 & 400 & 500 & 200 & See Method & \\
\hline 1,4-Dioxane & 50 & 100 & 200 & 400 & 500 & 200 & See Method & \\
\hline
\end{tabular}

All values are $u g / L$ without the prep factor.

\# Usual calibration levels using SIM methodology

Page 126 of 151 SDG: 528429 


\begin{tabular}{|c|c|c|c|c|c|c|c|c|c|c|}
\hline \multirow{2}{*}{\multicolumn{11}{|c|}{$\begin{array}{l}\text { SW846 8270SIM } \\
\text { Calibration Standard Concentration Levels* }\end{array}$}} \\
\hline & & & & & & & & & & \\
\hline MEGASIM analytes $(A)$ & Level 1 & Level 2 & Level3 & Level 4 & Level 5 & -evel 6f & Level 7 & Level 8 & Level 9 & Level 10 \\
\hline \multicolumn{11}{|c|}{ 1,4-Dichlorobenzene-d4 (INTERNAL STANDARD) } \\
\hline \multicolumn{11}{|c|}{ Naphthalene-d8 (INTERNAL STANDARD) } \\
\hline \multicolumn{11}{|c|}{ Acenaphthene-d10 (INTERNAL STANDARD) } \\
\hline \multicolumn{11}{|c|}{ Phenanthrene-d10 (INTERNAL STANDARD) } \\
\hline \multicolumn{11}{|c|}{ Chrysene-d12 (INTERNAL STANDARD) } \\
\hline \multicolumn{11}{|c|}{ Perylene-d12 (INTERNAL STANDARD) } \\
\hline 5-alpha-Androstane (SURROGATE) & $\$ 0.1$ & 0.2 & 0.5 & 1 & 2 & 5 & 10 & 20 & & \\
\hline \$N-Methyl-N-nitrosomethylamine & & 0.2 & 0.5 & 1 & 2 & 5 & 10 & 20 & & \\
\hline \$bis(2-Chloroethyl)ether & 0.1 & 0.2 & 0.5 & 1 & 2 & 5 & 10 & 20 & & \\
\hline \$N-Nitrosodipropylamine & 0.1 & 0.2 & 0.5 & 1 & 2 & 5 & 10 & 20 & & \\
\hline Naphthalene & $\$ 0.1$ & 0.2 & 0.5 & 1 & 2 & 5 & 10 & 20 & & \\
\hline 2-Methylnaphthalene & $\$ 0.1$ & 0.2 & 0.5 & 1 & 2 & 5 & 10 & 20 & & \\
\hline 1-Methylnaphthalene & $\$ 0.1$ & 0.2 & 0.5 & 1 & 2 & 5 & 10 & 20 & & \\
\hline 2-Chloronaphthalene & $\$ 0.1$ & 0.2 & 0.5 & 1 & 2 & 5 & 10 & 20 & & \\
\hline Acenaphthylene & $\$ 0.1$ & 0.2 & 0.5 & 1 & 2 & 5 & 10 & 20 & & \\
\hline Acenaphthene & $\$ 0.1$ & 0.2 & 0.5 & 1 & 2 & 5 & 10 & 20 & & \\
\hline Fluorene & $\$ 0.1$ & 0.2 & 0.5 & 1 & 2 & 5 & 10 & 20 & & \\
\hline Phenanthrene & $\$ 0.1$ & 0.2 & 0.5 & 1 & 2 & 5 & 10 & 20 & & \\
\hline Anthracene & $\$ 0.1$ & 0.2 & 0.5 & 1 & 2 & 5 & 10 & 20 & & \\
\hline Fluoranthene & $\$ 0.1$ & 0.2 & 0.5 & 1 & 2 & 5 & 10 & 20 & & \\
\hline Pyrene & $\$ 0.1$ & 0.2 & 0.5 & 1 & 2 & 5 & 10 & 20 & & \\
\hline Benzo(a)anthracene & $\$ 0.1$ & 0.2 & 0.5 & 1 & 2 & 5 & 10 & 20 & & \\
\hline Chrysene & $\$ 0.1$ & 0.2 & 0.5 & 1 & 2 & 5 & 10 & 20 & & \\
\hline Benzo(b)fluoranthene & $\$ 0.1$ & 0.2 & 0.5 & 1 & 2 & 5 & 10 & 20 & & \\
\hline Benzo(k)fluoranthene & $\$ 0.1$ & 0.2 & 0.5 & 1 & 2 & 5 & 10 & 20 & & \\
\hline Benzo(a)pyrene & $\$ 0.1$ & 0.2 & 0.5 & 1 & 2 & 5 & 10 & 20 & & \\
\hline Indeno-(1,2,3-cd)pyrene & $\$ 0.1$ & 0.2 & 0.5 & 1 & 2 & 5 & 10 & 20 & & \\
\hline Dibenzo(a,h)anthracene & $\$ 0.1$ & 0.2 & 0.5 & 1 & 2 & 5 & 10 & 20 & & \\
\hline Benzo(ghi)perylene & $\$ 0.1$ & 0.2 & 0.5 & 1 & 2 & 5 & 10 & 20 & & \\
\hline \multicolumn{11}{|c|}{ \$ By special request - Not for regulatory purposes } \\
\hline \multicolumn{11}{|c|}{ SW846 8270SIM } \\
\hline \multicolumn{11}{|c|}{ Calibration Standard Concentration Levels ${ }^{\star}$} \\
\hline APSIM analytes $(A)$ & Level 1 & Level 2 & Level3 & Level 4 & Level 5 & -evel 6f & Level 7 & Level 8 & Level 9 & Level 10 \\
\hline \$N-Nitrosodimethylamine & 0.1 & 0.2 & 0.5 & 1 & 2 & 5 & 10 & 20 & & \\
\hline \$N-Nitrosopyrrolidine & 0.1 & 0.2 & 0.5 & 1 & 2 & 5 & 10 & 20 & & \\
\hline \$N-Nitrosodi-n-butylamine & 0.1 & 0.2 & 0.5 & 1 & 2 & 5 & 10 & 20 & & \\
\hline \$Benzidine & & & 2.5 & 5 & 10 & 25 & 50 & 100 & & \\
\hline$\$ 3,3^{\prime}$-Dichlorobenzidine & 0.1 & 0.2 & 0.5 & 1 & 2 & 5 & 10 & 20 & & \\
\hline
\end{tabular}

$\$$ By special request - Not for regulatory purposes

All values are $\mathrm{mg} / \mathrm{L}$ without prep factor.

\# indicates the calibraton verification concentration level used.

* Usual calibration levels using SIM methodology

(10/16/Full list)

Page 127 of 151 SDG: 528429 
Calibration History Report MSD1

GEL Laboratories, LLC

Method File : D: MSDCHEM \1\Data\S113020.B\MSD1_SIMPAHPLUS_8270C_8270D_111720.m

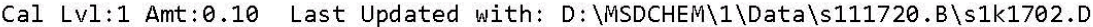

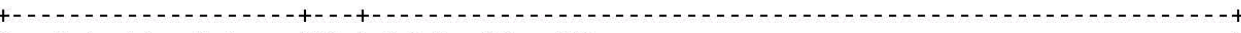

| Injection Date |Mix| Calibration File |

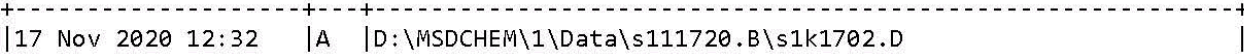

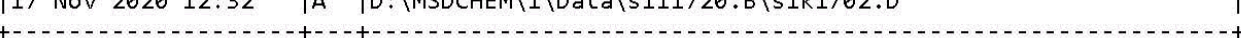

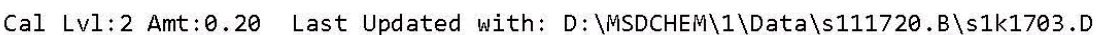

+-.-_-

| Injection Date $\mid$ Mix| Calibration File |

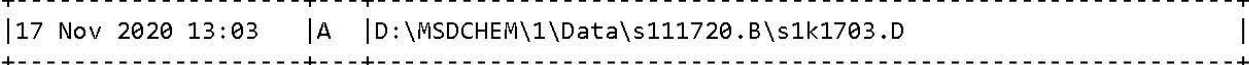

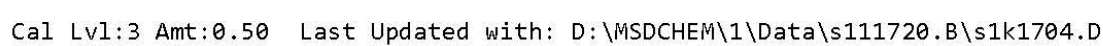

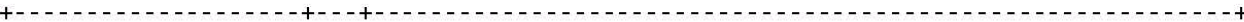

| Injection Date |Mix| Calibration File |

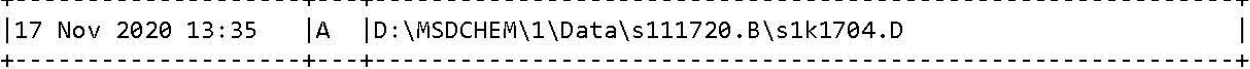

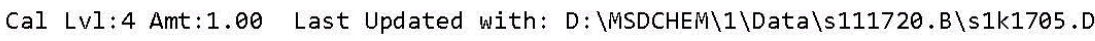

+

Injection Date $\mid$ Mix| Calibration File

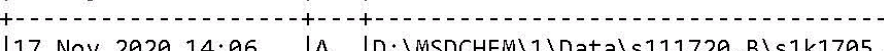

117

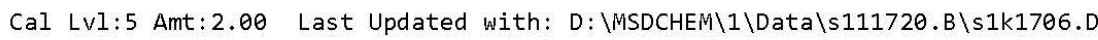

+-10

| Injection Date $\mid$ Mix| Calibration File

|17 Nov 2020 14:38

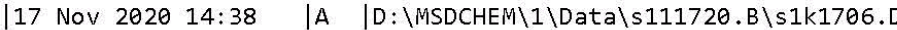

+-_._-

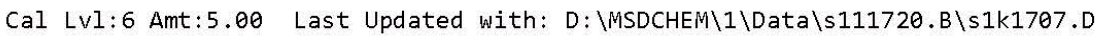

+

| Injection Date $\mid$ Mix| Calibration File |

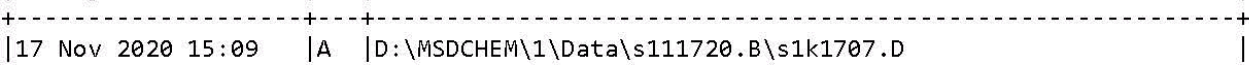

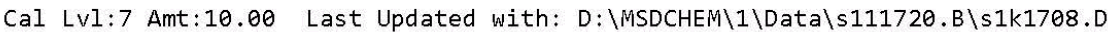

| Injection Date |Mix| Calibration File

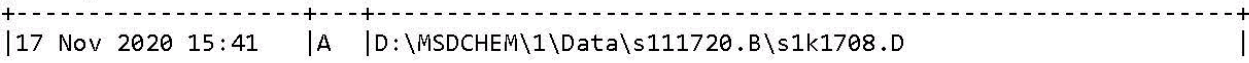

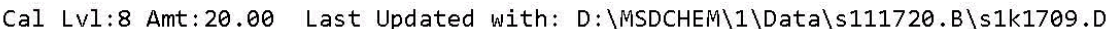

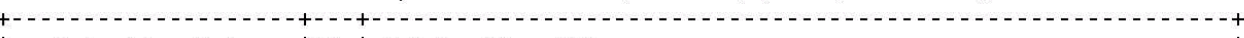

| Injection Date $\mid$ Mix| Calibration File |

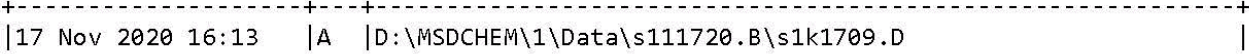

MSD1_SIMPAH...70D_111720.m Mon Nov $3018: 35: 432020$

MSD1_SIMPAH...70D_111720.m Mon Nov 30 18:35:41 2020

Page 128 of 151 SDG: 528429 
Calibration History Report MSD1

GEL Laboratories, LLC

Method File : D: MSDCHEM \1\Data \S120120.B\MSD1_SIMPAHPLUS_8270C_8270D_111720.m

Last Update : Tue Nov 17 18:19:42 2020

Integrator : (RTE Integrator)

Response via : Initial Calibration

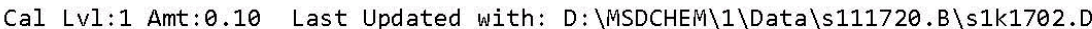

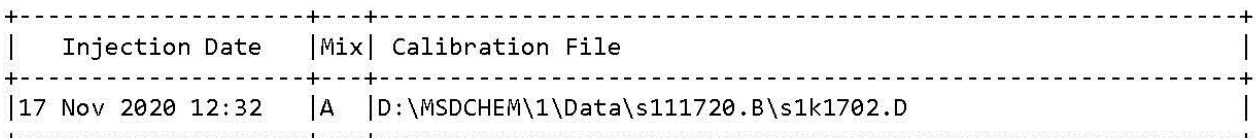

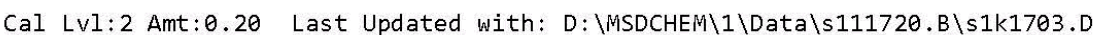

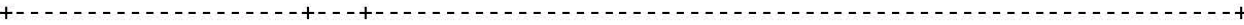
| Injection Date $\mid$ Mix| Calibration File |

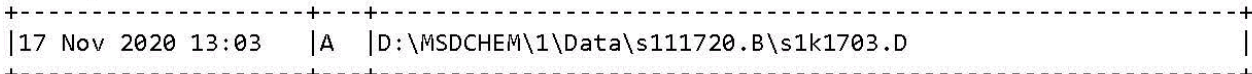

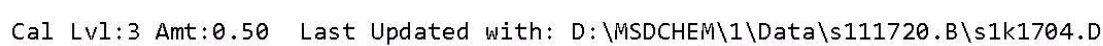

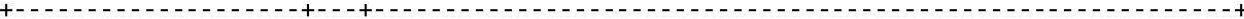
| Injection Date $\mid$ Mix| Calibration File |

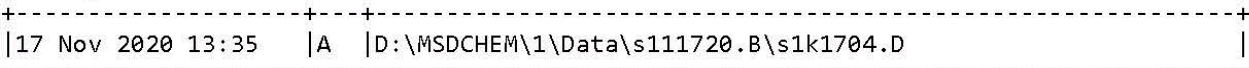
|17

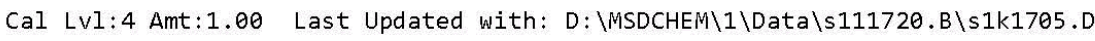
+ I Injection Date $\mid$ Mix| Calibration File

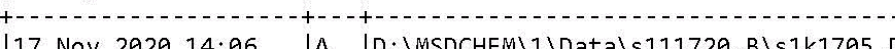

+-17

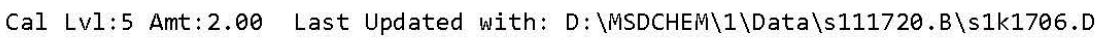
+ | Injection Date $\mid$ Mix| Calibration File |17 nov 2020 14:38

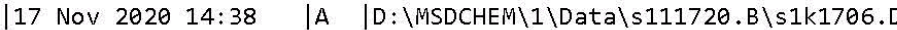

+-.

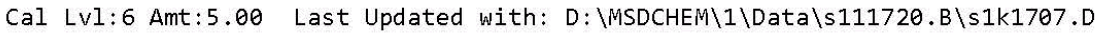
(| Injection Date $\mid$ Mix| Calibration File

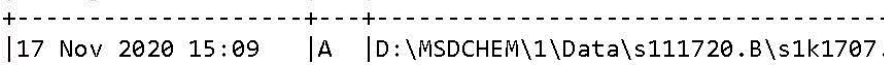

(1)

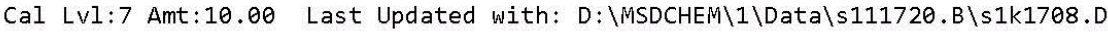
Injection Date |Mix| Calibration File

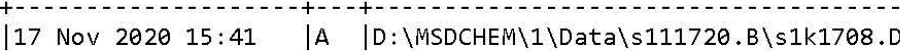

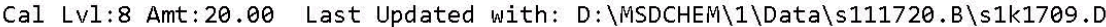

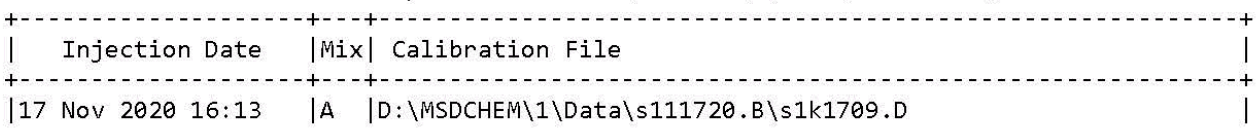

MSD1_SIMPAH...70D_111720.m Tue Dec 01 13:00:46 2020

MSD1_SIMPAH...70D_111720.m Tue Dec 01 13:00:44 2020

Page 129 of 151 SDG: 528429 


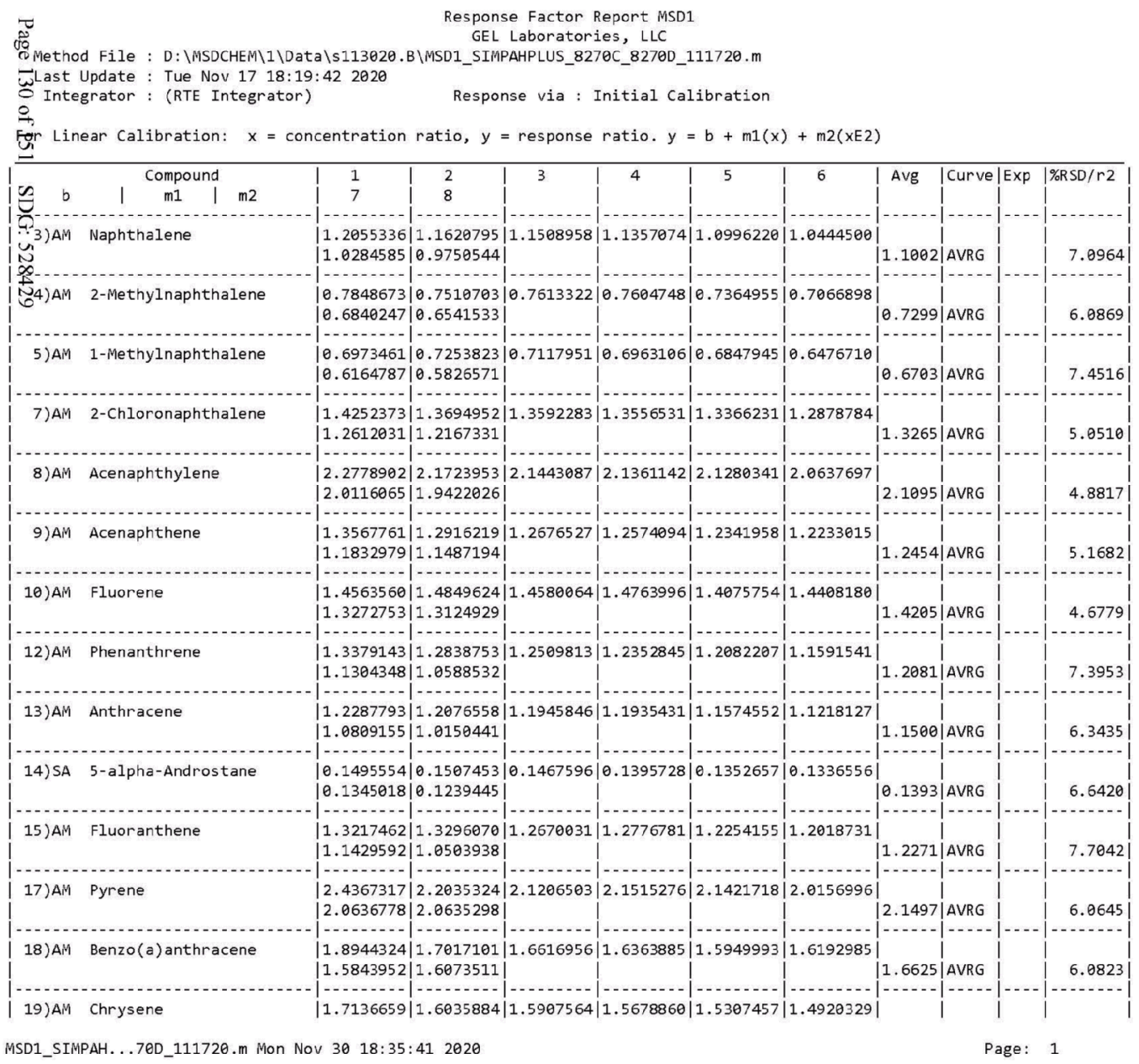




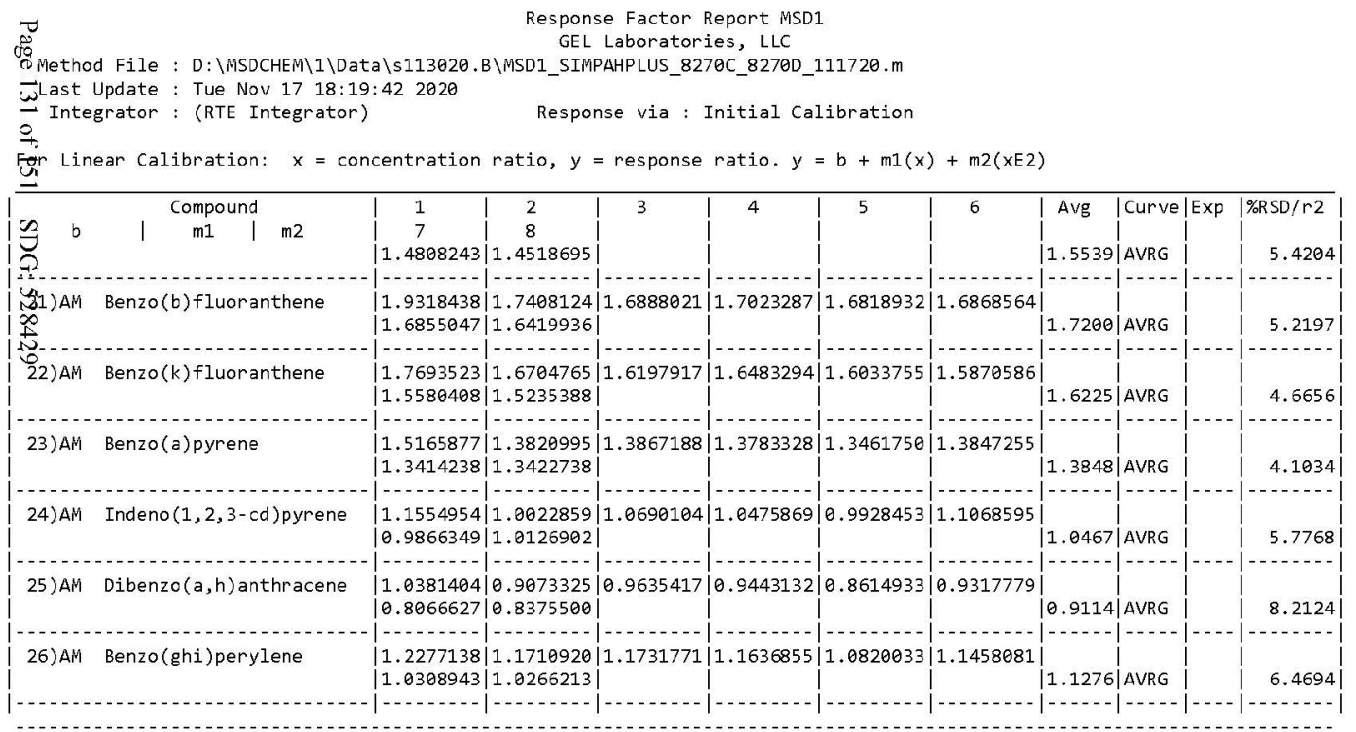

(\#) = Out of Range (\$) = Individual RF Out of Range

AVRG $=$ Average, $\operatorname{LINR}=$ Linear Regression, $1 / x=$ the inverse of concentration, $1 / x^{\wedge} 2=$ the inverse square of concentration 


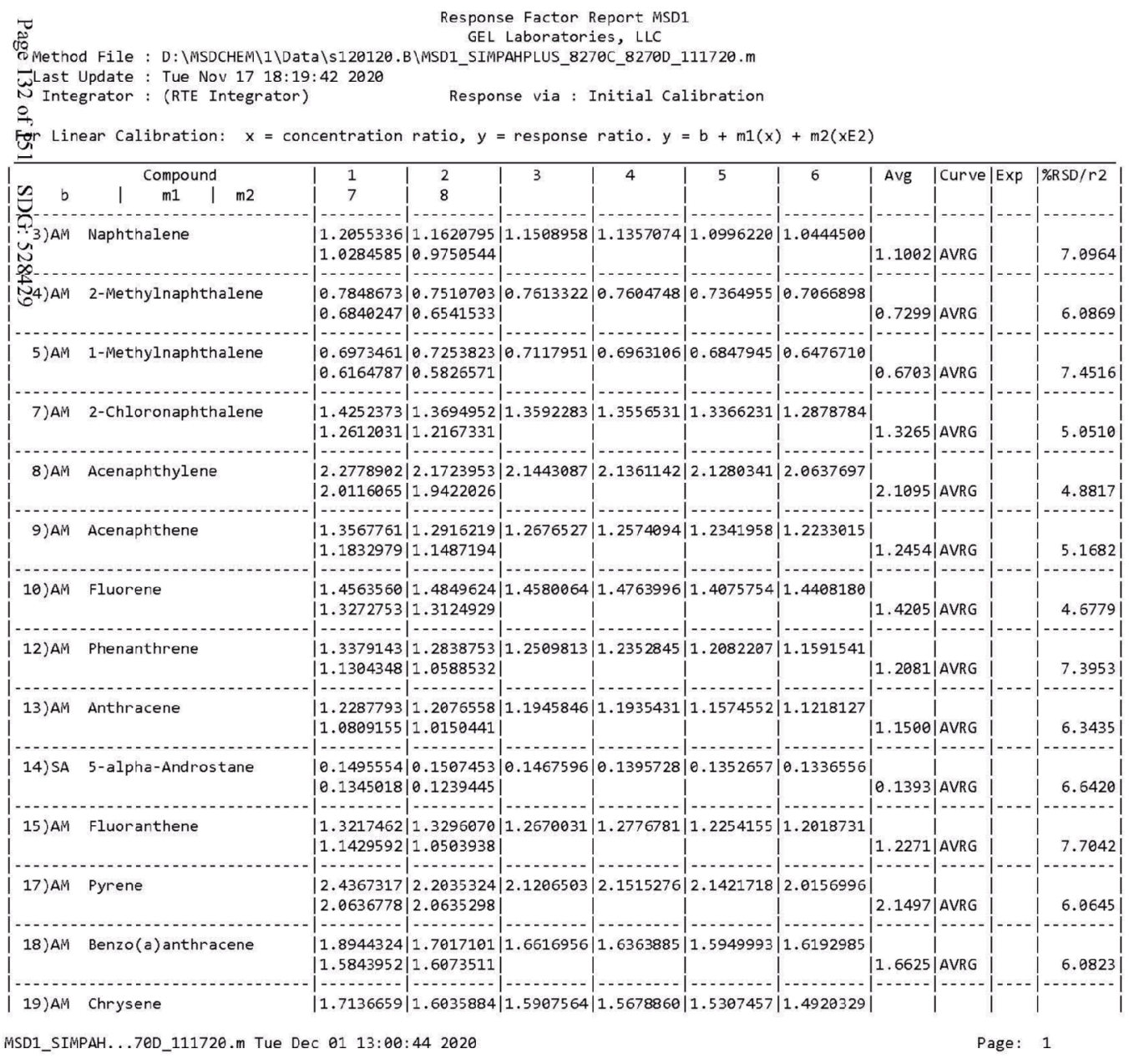




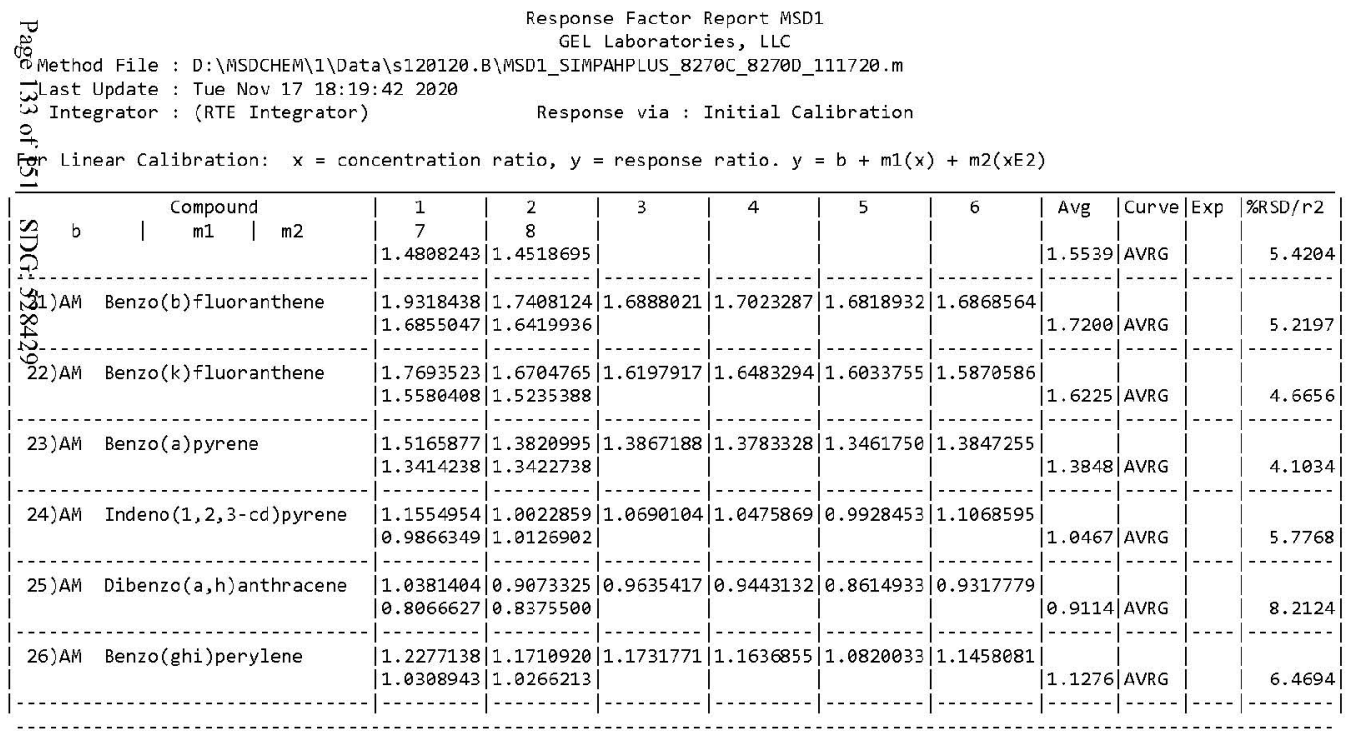

(\#) = Out of Range $(\$)$ = Individual RF Out of Range

AVRG $=$ Average, $\operatorname{LINR}=$ Linear Regression, $1 / x=$ the inverse of concentration, $1 / x^{\wedge} 2=$ the inverse square of concentration 
Continuing Calibration Summary

Page 1 of 1

Instrument ID: MSD1.I

Client SDG: $\quad 528429$

Data File: $\quad$ s111720.B\s1k1710.D

Injection Date: $\quad$ 17-NOV-20 16:45

Init. Cal. Date(s) : 17-NOV-20 12:32 - 17-NOV-20 16:1

Lab Sample ID WBN200625-89

Method: s111720.BLMSD1_SIMPAHPLUS_8270C_8270D_

Quant Type ISTD

Method Update: $\quad$ 17-NOV-20 18:19

\begin{tabular}{|l|r|r|r|r|r|r|r|r|r|}
\hline Compound & $\begin{array}{c}\text { AVERF / } \\
\text { Amount }\end{array}$ & $\begin{array}{c}\text { RF } \\
\text { CCV }\end{array}$ & $\begin{array}{c}\text { Nominal } \\
\text { CCV }\end{array}$ & Min RF & $\begin{array}{c}\text { RF } \\
\text { Q }\end{array}$ & $\begin{array}{c}\text { \%D / } \\
\text { \%Drift }\end{array}$ & $\begin{array}{c}\text { Max } \\
\text { S }\end{array}$ & $\begin{array}{c}\text { Drift } \\
\text { Qurve } \\
\text { Type }\end{array}$ \\
\hline 5-alpha-Androstane & 0.1393 & 0.14424 & & .01 & & 3.5463 & 60 & & Averaged \\
\hline Naphthalene & 1.1002 & 1.01829 & & .7 & & -7.44501 & 60 & & Averaged \\
\hline Acenaphthene & 1.2454 & 1.23515 & & .9 & & -0.82303 & 20 & & Averaged CCC \\
\hline Fluorene & 1.4205 & 1.42743 & .9 & & 0.48786 & 60 & & Averaged \\
\hline Anthracene & 1.15 & 1.0658 & .7 & & -7.32174 & 60 & & Averaged \\
\hline Fluoranthene & 1.2271 & 1.07129 & .6 & & -12.69742 & 20 & & Averaged CCC \\
\hline Pyrene & 2.1497 & 2.0032 & .6 & & -6.8149 & 60 & & Averaged \\
\hline Benzo(a)anthracene & 1.6625 & 1.33342 & .8 & & -19.79429 & 60 & & Averaged \\
\hline Chrysene & 1.5539 & 1.28901 & .7 & -17.04679 & 60 & & Averaged \\
\hline Benzo(b)fluoranthene & 1.72 & 1.59267 & .7 & & -7.40291 & 60 & & Averaged \\
\hline Benzo(k)fluoranthene & 1.6225 & 1.50646 & .7 & & -7.15193 & 60 & & Averaged \\
\hline Benzo(a)pyrene & 1.3848 & 1.33403 & .7 & & -3.66623 & 20 & & Averaged CCC \\
\hline
\end{tabular}

Page 134 of $151 \quad$ SDG: 528429 
Continuing Calibration Summary

Page 1 of 1

Instrument ID: MSD1.I

Client SDG: $\quad 528429$

Data File: $\quad$ s113020.B \s1k3002.D

Injection Date: $\quad$ 30-NOV-20 13:36

Init. Cal. Date(s): $\quad$ 17-NOV-20 12:32 - 17-NOV-20 16:1

Lab Sample ID WBN201120-86.4

Method: s113020.BIMSD1_SIMPAHPLUS_8270C_8270D

Quant Type ISTD

Method Update: $\quad$ 17-NOV-20 18:19

\begin{tabular}{|l|r|r|r|r|r|r|r|r|r|}
\hline Compound & $\begin{array}{c}\text { AVERF / } \\
\text { Amount }\end{array}$ & $\begin{array}{c}\text { RF } \\
\text { CCV }\end{array}$ & $\begin{array}{c}\text { Nominal } \\
\text { CCV }\end{array}$ & Min RF & $\begin{array}{c}\text { RF } \\
\text { Q }\end{array}$ & $\begin{array}{c}\text { \%D / } \\
\text { \%Drift }\end{array}$ & $\begin{array}{c}\text { Max } \\
\text { S }\end{array}$ & $\begin{array}{c}\text { Drift } \\
\text { Qurve } \\
\text { Type }\end{array}$ \\
\hline 5-alpha-Androstane & 0.1393 & 0.14012 & & .01 & & 0.58866 & 60 & & Averaged \\
\hline Naphthalene & 1.1002 & 1.0606 & & .7 & & -3.59935 & 60 & & Averaged \\
\hline Acenaphthene & 1.2454 & 1.29507 & .9 & & 3.98828 & 20 & & Averaged CCC \\
\hline Fluorene & 1.4205 & 1.50671 & & .9 & & 6.06899 & 60 & & Averaged \\
\hline Anthracene & 1.15 & 1.1041 & & .7 & & -3.9913 & 60 & & Averaged \\
\hline Fluoranthene & 1.2271 & 1.17394 & .6 & & -4.33217 & 20 & & Averaged CCC \\
\hline Pyrene & 2.1497 & 2.0541 & .6 & & -4.44713 & 60 & & Averaged \\
\hline Benzo(a)anthracene & 1.6625 & 1.59088 & .8 & & -4.30797 & 60 & & Averaged \\
\hline Chrysene & 1.5539 & 1.48099 & .7 & & -4.69207 & 60 & & Averaged \\
\hline Benzo(b)fluoranthene & 1.72 & 1.63352 & .7 & & -5.02791 & 60 & & Averaged \\
\hline Benzo(k)fluoranthene & 1.6225 & 1.5367 & .7 & & -5.28814 & 60 & & Averaged \\
\hline Benzo(a)pyrene & 1.3848 & 1.36483 & .7 & & -1.44209 & 20 & & Averaged CCC \\
\hline
\end{tabular}

Page 135 of $151 \quad$ SDG: 528429 
Continuing Calibration Summary

Page 1 of 1

Instrument ID: MSD1.I

Client SDG: $\quad 528429$

Data File: $\quad$ s113020.B \s1k3010.D

Injection Date: $\quad 30-N O V-20$ 18:06

Init. Cal. Date(s) $\quad$ 17-NOV-20 12:32 - 17-NOV-20 16:1

Lab Sample ID WBN201120-86.4

Method: s113020.BIMSD1_SIMPAHPLUS_8270C_8270D

Quant Type ISTD

Method Update: $\quad$ 17-NOV-20 18:19

\begin{tabular}{|l|r|r|r|r|r|r|r|r|r|}
\hline Compound & $\begin{array}{c}\text { AVERF / } \\
\text { Amount }\end{array}$ & $\begin{array}{c}\text { RF } \\
\text { CCV }\end{array}$ & $\begin{array}{c}\text { Nominal } \\
\text { CCV }\end{array}$ & Min RF & $\begin{array}{c}\text { RF } \\
\text { Q }\end{array}$ & $\begin{array}{c}\text { \%D / } \\
\text { \%Drift }\end{array}$ & $\begin{array}{c}\text { Max } \\
\text { S }\end{array}$ & $\begin{array}{c}\text { Drift } \\
\text { Qurve } \\
\text { Type }\end{array}$ \\
\hline 5-alpha-Androstane & 0.1393 & 0.14466 & & .01 & & 3.84781 & 60 & & Averaged \\
\hline Naphthalene & 1.1002 & 1.06321 & & .7 & & -3.36212 & 60 & & Averaged \\
\hline Acenaphthene & 1.2454 & 1.28603 & & .9 & & 3.26241 & 20 & & Averaged CCC \\
\hline Fluorene & 1.4205 & 1.48164 & .9 & & 4.30412 & 60 & & Averaged \\
\hline Anthracene & 1.15 & 1.09441 & .7 & & -4.83391 & 60 & & Averaged \\
\hline Fluoranthene & 1.2271 & 1.08397 & .6 & & -11.66409 & 20 & & Averaged CCC \\
\hline Pyrene & 2.1497 & 2.3949 & .6 & & 11.40624 & 60 & & Averaged \\
\hline Benzo(a)anthracene & 1.6625 & 1.58671 & .8 & & -4.5588 & 60 & & Averaged \\
\hline Chrysene & 1.5539 & 1.48622 & .7 & & -4.35549 & 60 & & Averaged \\
\hline Benzo(b)fluoranthene & 1.72 & 1.64724 & .7 & & -4.23023 & 60 & & Averaged \\
\hline Benzo(k)fluoranthene & 1.6225 & 1.54558 & .7 & & -4.74083 & 60 & & Averaged \\
\hline Benzo(a)pyrene & 1.3848 & 1.33566 & .7 & & -3.54853 & 20 & & Averaged CCC \\
\hline
\end{tabular}

Page 136 of $151 \quad$ SDG: 528429 
Continuing Calibration Summary

Page 1 of 1

Instrument ID: MSD1.I

Client SDG: $\quad 528429$

Data File: $\quad$ s120120.Bis1L0106.D

Injection Date: $\quad$ 01-DEC-20 12:32

Init. Cal. Date(s) : 17-NOV-20 12:32 - 17-NOV-20 16:1

Lab Sample ID WBN201120-82.1

Method: s120120.BLMSD1_SIMPAHPLUS_8270C_8270D_

Quant Type ISTD

Method Update: $\quad$ 17-NOV-20 18:19

\begin{tabular}{|l|r|r|r|r|r|r|r|r|r|}
\hline Compound & $\begin{array}{c}\text { AVERF / } \\
\text { Amount }\end{array}$ & $\begin{array}{c}\text { RF } \\
\text { CCV }\end{array}$ & $\begin{array}{c}\text { Nominal } \\
\text { CCV }\end{array}$ & Min RF & $\begin{array}{c}\text { RF } \\
\text { Q }\end{array}$ & $\begin{array}{c}\text { \%D / } \\
\text { \%Drift }\end{array}$ & $\begin{array}{c}\text { Max } \\
\text { S }\end{array}$ & $\begin{array}{c}\text { Drift } \\
\text { Q }\end{array}$ & $\begin{array}{c}\text { Type } \\
\text { Sype }\end{array}$ \\
\hline 5-alpha-Androstane & 0.1393 & 0.12602 & & .01 & & -9.53338 & 60 & & Averaged \\
\hline Naphthalene & 1.1002 & 1.05778 & & .7 & & -3.85566 & 60 & & Averaged \\
\hline Acenaphthene & 1.2454 & 1.29666 & .9 & & 4.11595 & 20 & & Averaged CCC \\
\hline Fluorene & 1.4205 & 1.50582 & .9 & & 6.00634 & 60 & & Averaged \\
\hline Anthracene & 1.15 & 1.1014 & .7 & -4.22609 & 60 & & Averaged \\
\hline Fluoranthene & 1.2271 & 1.16248 & .6 & & -5.26607 & 20 & & Averaged CCC \\
\hline Pyrene & 2.1497 & 2.20864 & .6 & & 2.74178 & 60 & & Averaged \\
\hline Benzo(a)anthracene & 1.6625 & 1.64247 & .8 & & -1.20481 & 60 & & Averaged \\
\hline Chrysene & 1.5539 & 1.58341 & .7 & & 1.89909 & 60 & & Averaged \\
\hline Benzo(b)fluoranthene & 1.72 & 1.38112 & .7 & & -19.70233 & 60 & & Averaged \\
\hline Benzo(k)fluoranthene & 1.6225 & 1.32487 & .7 & & -18.34391 & 60 & & Averaged \\
\hline Benzo(a)pyrene & 1.3848 & 1.16759 & .7 & & -15.6853 & 20 & & Averaged CCC
\end{tabular}

Page 137 of $151 \quad$ SDG: 528429 


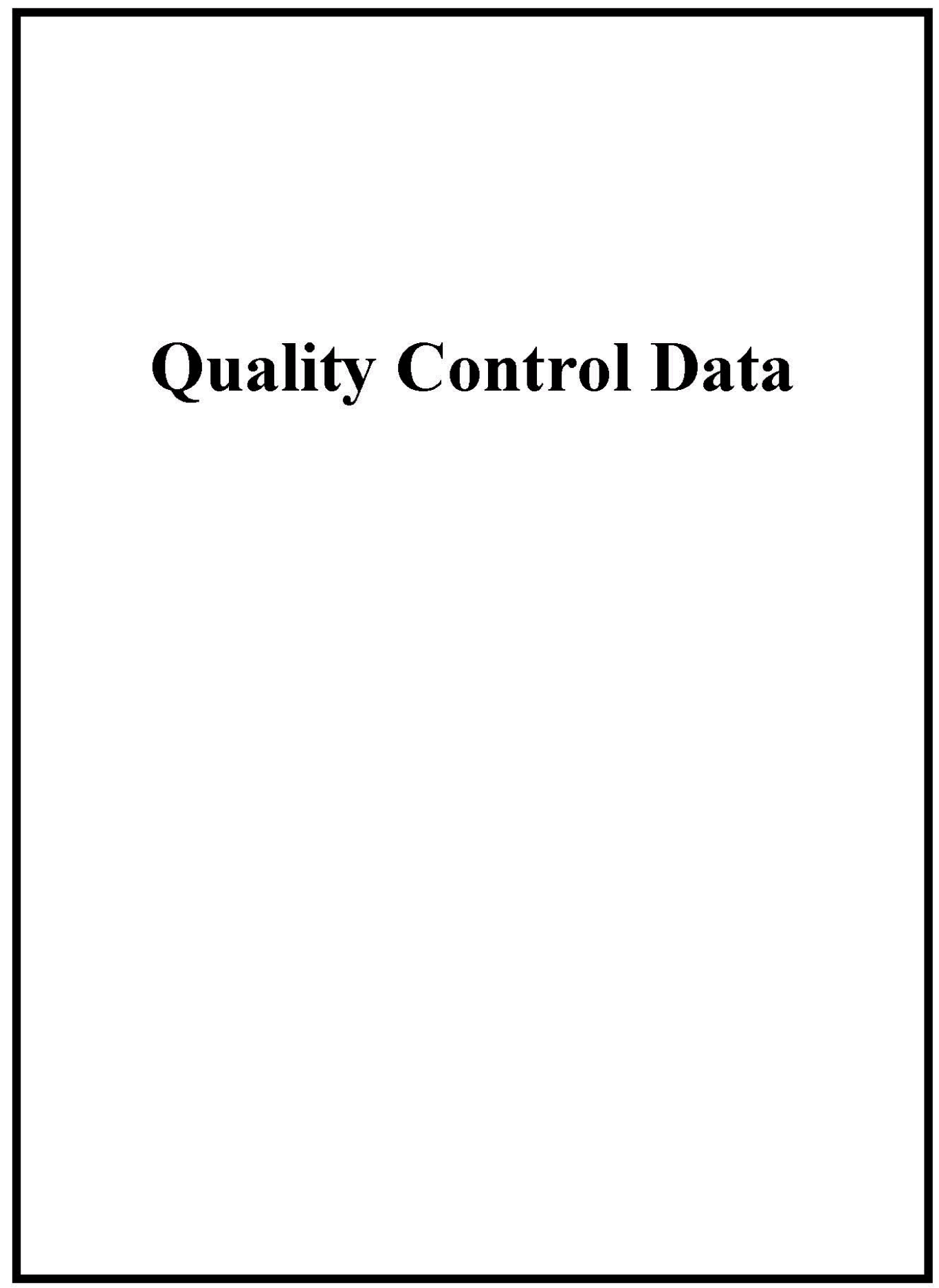

Page 138 of 151 SDG: 528429 


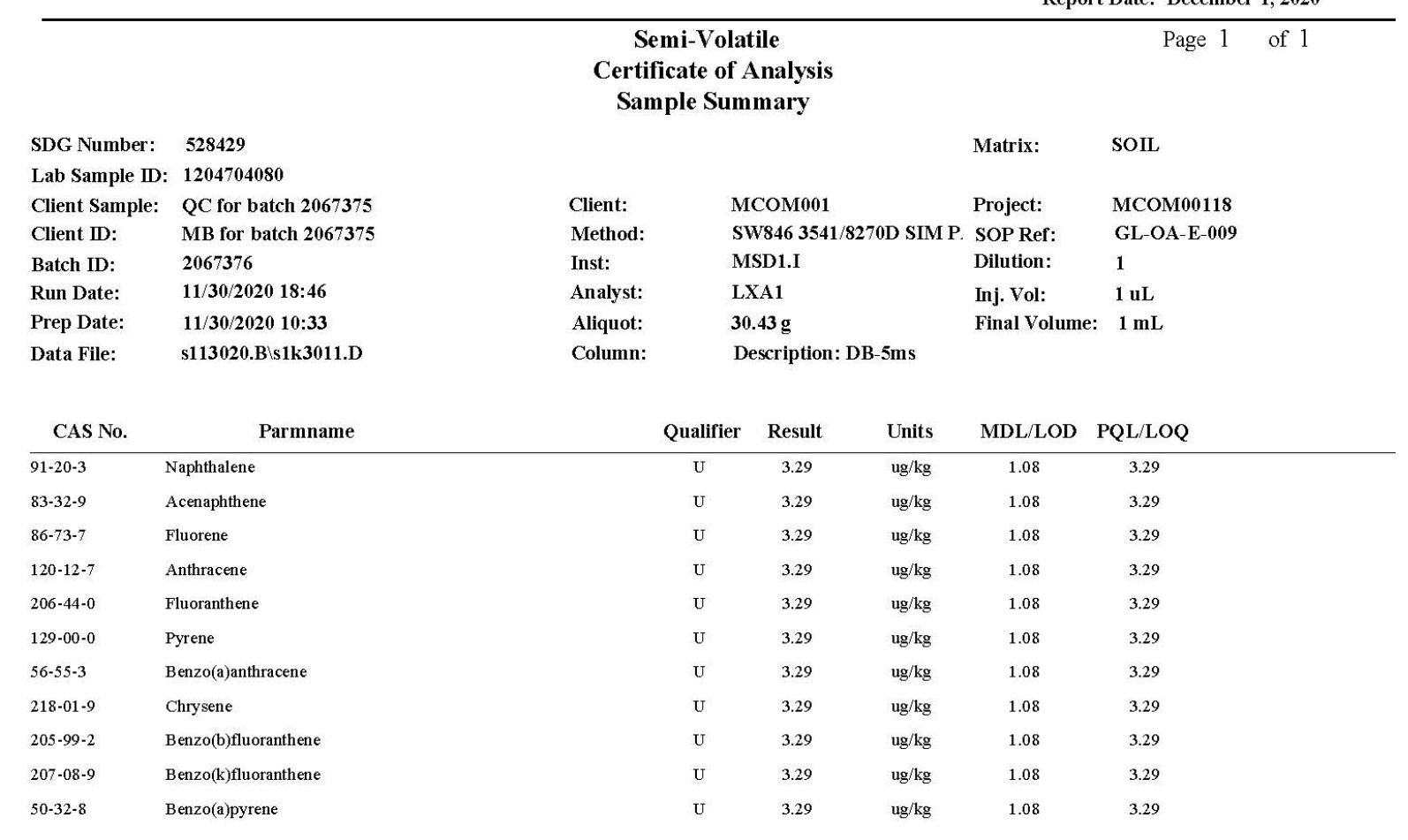

Page 139 of 151 SDG: 528429 


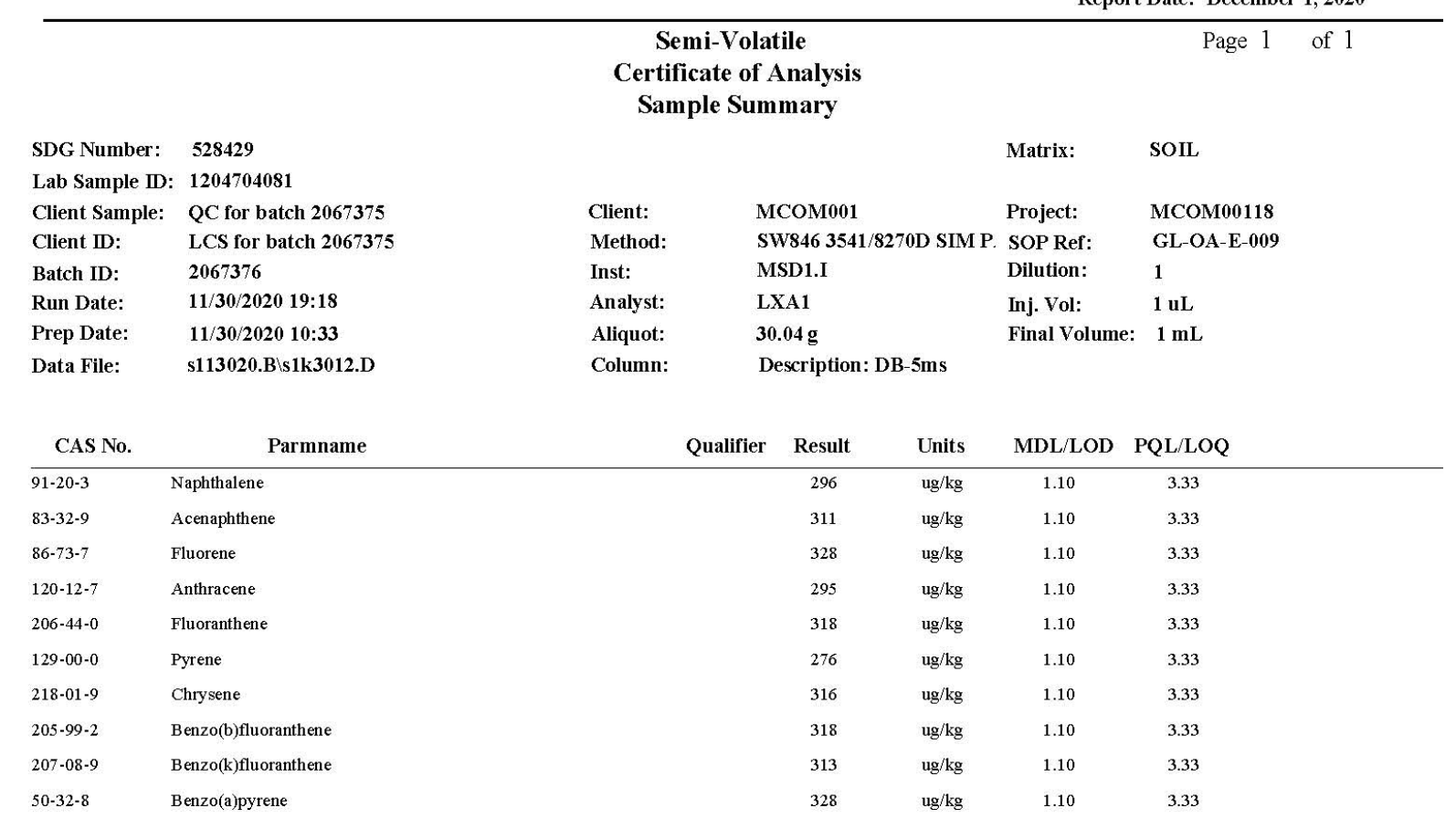

Page 140 of 151 SDG: 528429 


\begin{tabular}{|c|c|c|c|c|c|c|c|}
\hline \multirow[b]{2}{*}{ SDG Number: } & \multirow[b]{2}{*}{528429} & \multicolumn{4}{|c|}{$\begin{array}{c}\text { Semi-Volatile } \\
\text { Certificate of Analysis } \\
\text { Sample Summary }\end{array}$} & \multirow{2}{*}{\multicolumn{2}{|c|}{ Page 1 of 1}} \\
\hline & & Date Collected: & \multicolumn{3}{|c|}{$11 / 16 / 202012: 50$} & & \\
\hline Lab Sample ID: & 1204704082 & Date Received: & \multicolumn{3}{|c|}{$11 / 17 / 202007: 20$} & \%Moisture: & 7.9 \\
\hline Client Sample: & QC for batch 2067375 & Client: & \multicolumn{2}{|c|}{ MCOM001 } & & Project: & MCOM00118 \\
\hline Client ID: & CV-SB-2E-1.0MS & Method: & \multicolumn{3}{|c|}{ SW846 3541/8270D SIM P. } & SOP Ref: & GL-OA-E-009 \\
\hline Batch ID: & 2067376 & Inst: & \multicolumn{3}{|c|}{ MSD1.I } & Dilution: & 10 \\
\hline Run Date: & $11 / 30 / 202022: 28$ & Analyst: & \multicolumn{3}{|c|}{ LXA1 } & Inj. Vol: & $1 \mathrm{uL}$ \\
\hline Prep Date: & $11 / 30 / 202010: 33$ & Aliquot: & \multicolumn{3}{|c|}{$30.12 \mathrm{~g}$} & \multicolumn{2}{|c|}{ Final Volume: $1 \mathrm{~mL}$} \\
\hline Data File: & s113020.B \s1k3018.D & Column: & \multicolumn{3}{|c|}{ Description: DB-5ms } & & \\
\hline CAS No. & Parmname & Qual & & Result & Units & $\mathrm{MDL} / \mathrm{LOD}$ & PQL/LOQ \\
\hline $91-20-3$ & Naphthalene & & & 169 & $\mathrm{ug} / \mathrm{kg}$ & 11.9 & 36.0 \\
\hline $83-32-9$ & Acenaphthene & & & 137 & $\mathrm{ug} / \mathrm{kg}$ & 11.9 & 36.0 \\
\hline 86-73-7 & Fluorene & & & 148 & $\mathrm{ug} / \mathrm{kg}$ & 11.9 & 36.0 \\
\hline $120-12-7$ & Anthracene & & & 159 & $\mathrm{ug} / \mathrm{kg}$ & 11.9 & 36.0 \\
\hline $206-44-0$ & Fluoranthene & & & 397 & $\mathrm{ug} / \mathrm{kg}$ & 11.9 & 36.0 \\
\hline $129-00-0$ & Pyrene & & & 415 & $\mathrm{ug} / \mathrm{kg}$ & 11.9 & 36.0 \\
\hline 218-01-9 & Chrysene & & & 360 & $\mathrm{ug} / \mathrm{kg}$ & 11.9 & 36.0 \\
\hline $205-99-2$ & Benzo(b)fluoranthene & & & 425 & $\mathrm{ug} / \mathrm{kg}$ & 11.9 & 36.0 \\
\hline $207-08-9$ & Benzo(k)fluoranthene & & & 242 & $\mathrm{ug} / \mathrm{kg}$ & 11.9 & 36.0 \\
\hline $50-32-8$ & Benzo(a)pyrene & & & 314 & $\mathrm{ug} / \mathrm{kg}$ & 11.9 & 36.0 \\
\hline
\end{tabular}

Page 141 of 151 SDG: 528429 


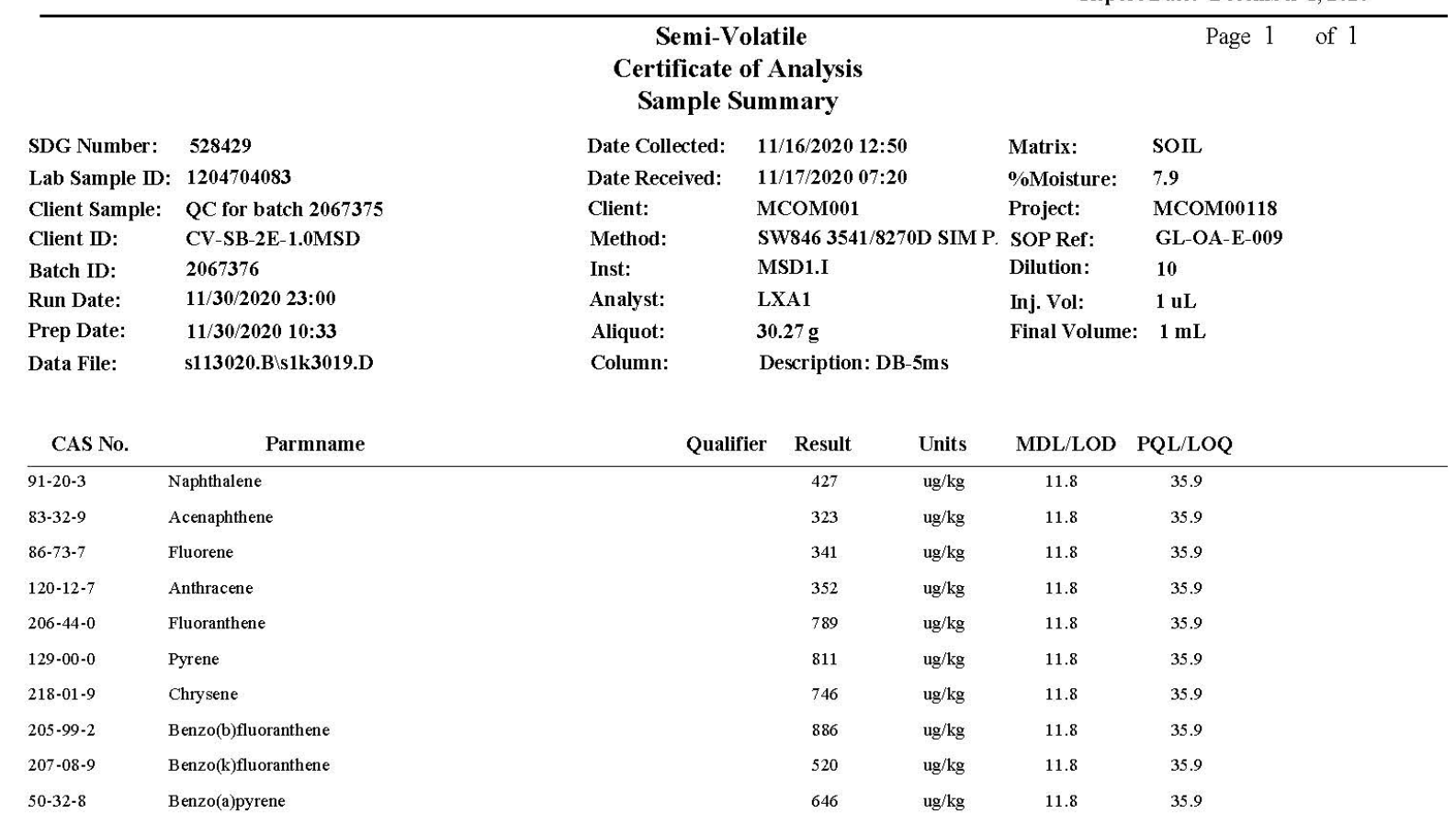

Page 142 of 151 SDG: 528429 


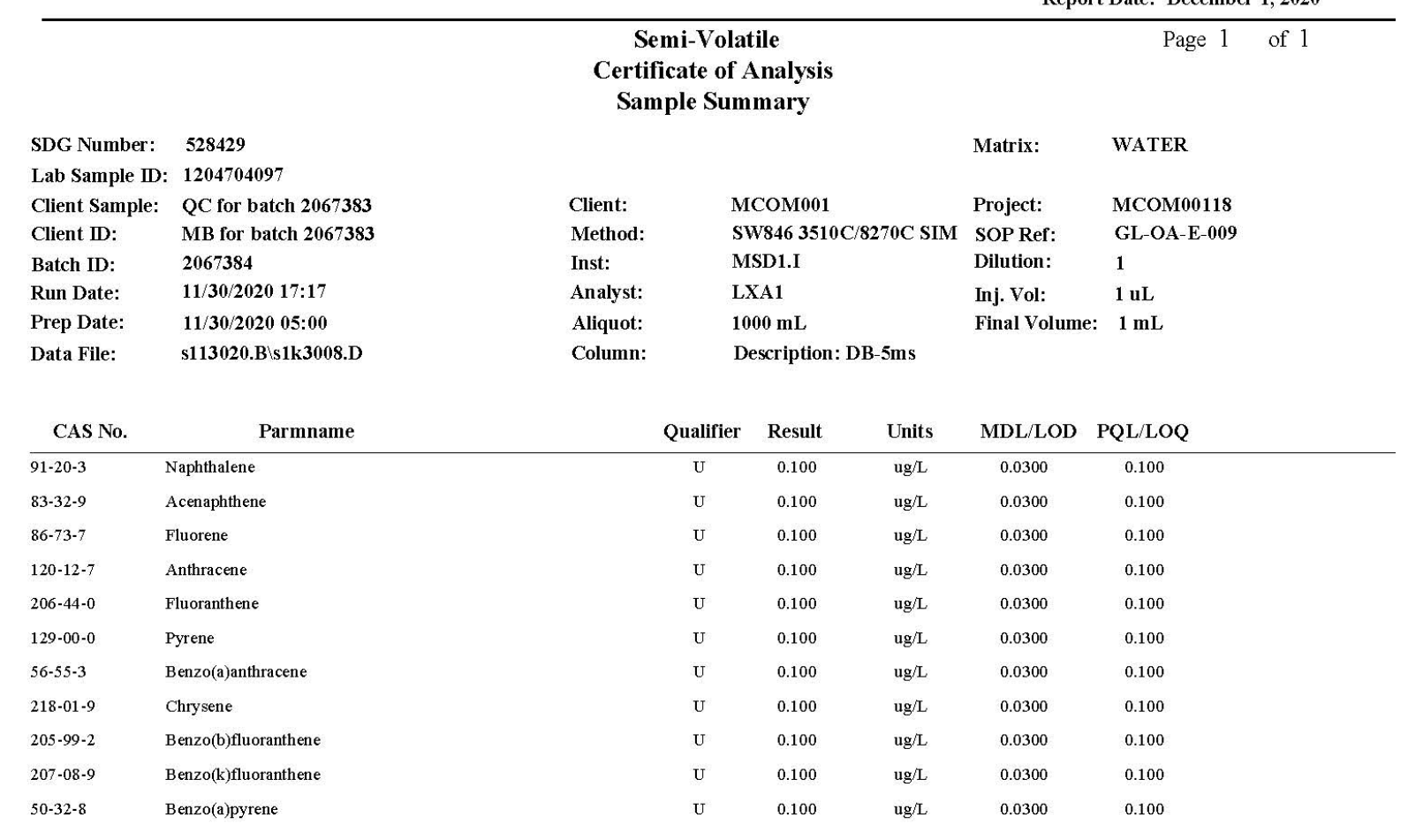

Page 143 of 151 SDG: 528429 


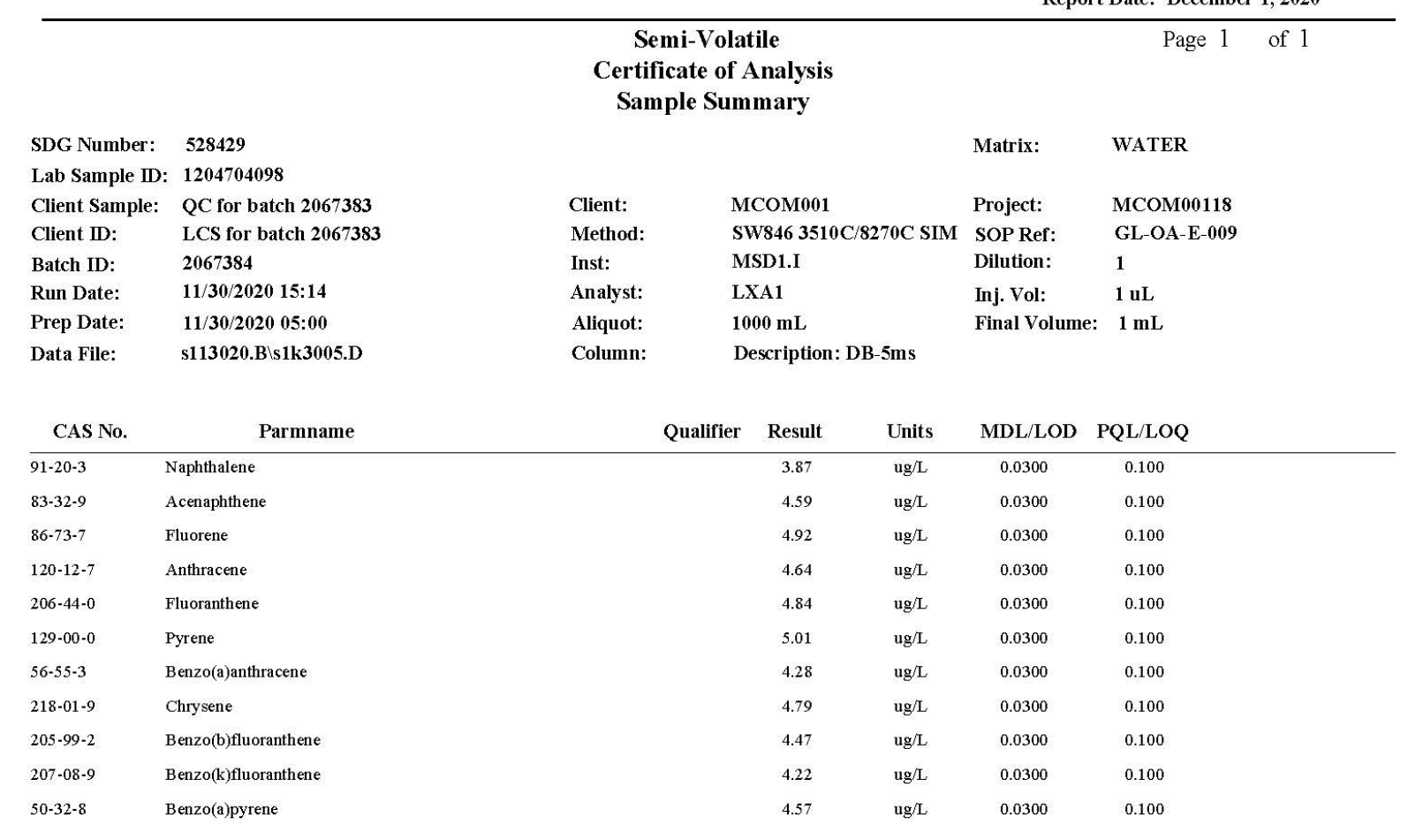

Page 144 of 151 SDG: 528429 


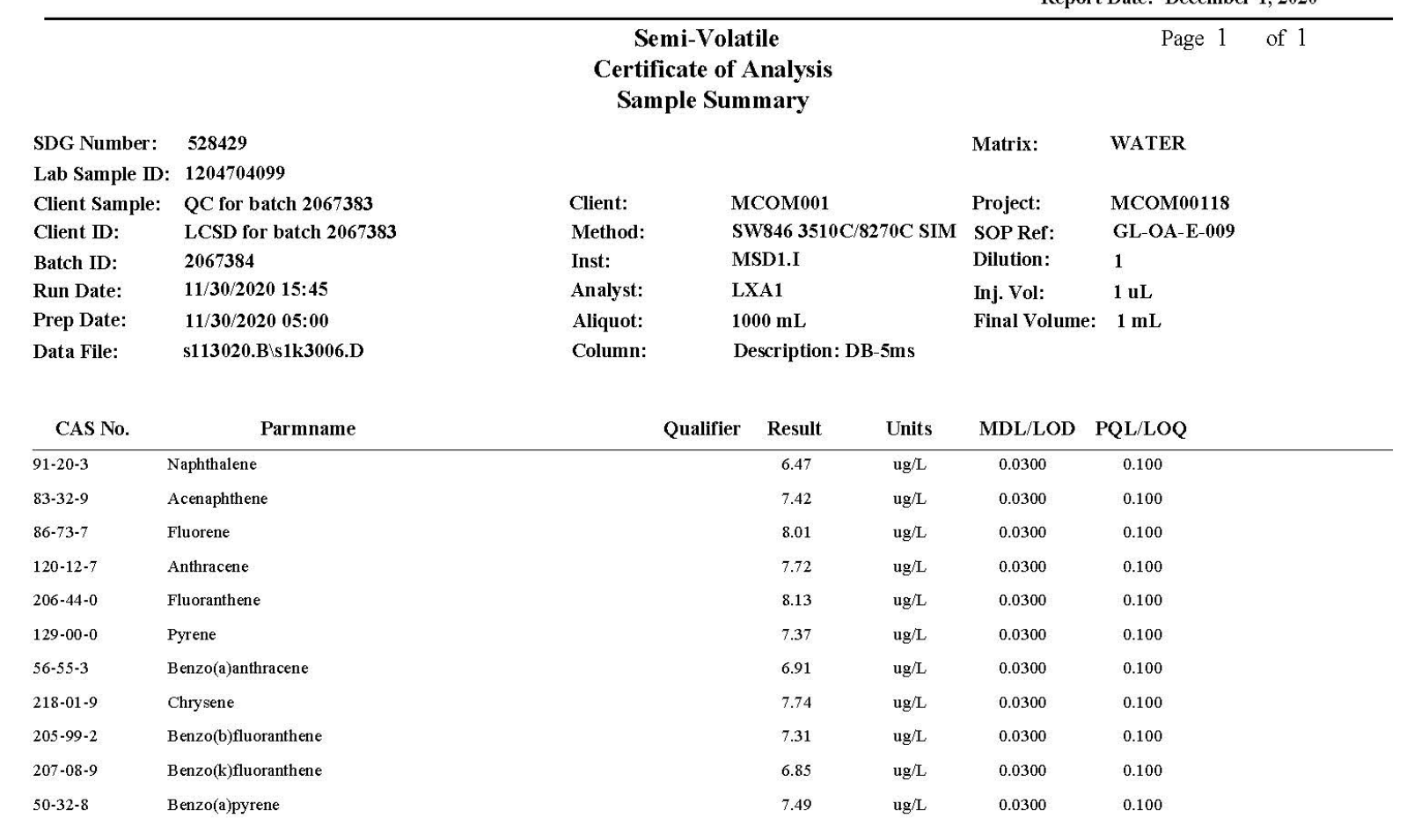

Page 145 of 151 SDG: 528429 


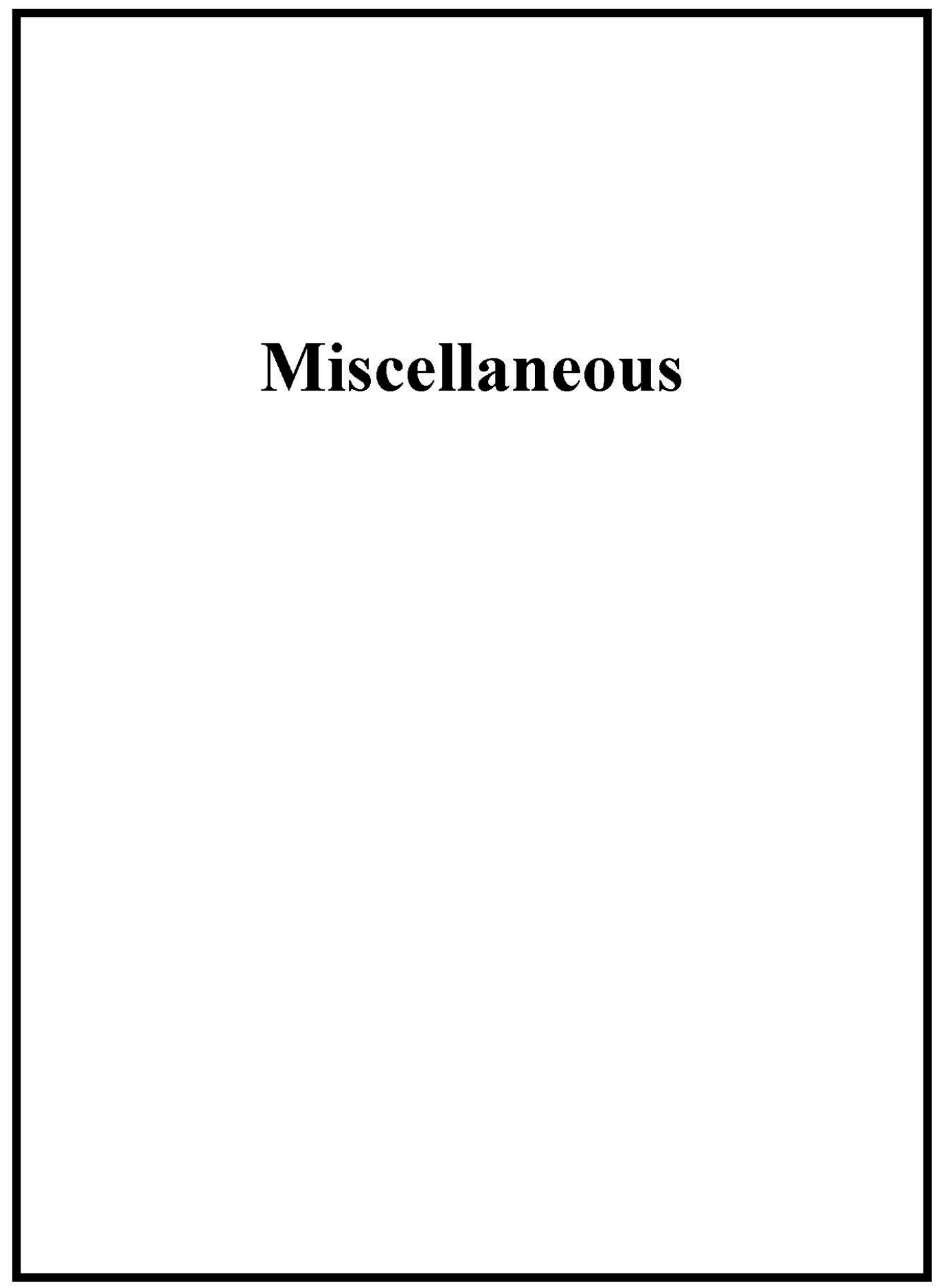

Page 146 of 151 SDG: 528429 
Prep Logbook

Automated Soxhlet Extraction

\begin{tabular}{|c|c|c|c|c|c|c|c|c|}
\hline \multicolumn{2}{|c|}{$\begin{array}{l}\text { Batch W: } \\
\text { Analyst: } \\
\text { Method: }\end{array}$} & $\begin{array}{l}375 \\
\text { cy Grant } \\
463541\end{array}$ & ed by: & & & & & $\begin{array}{l}\text { Lab SOP: GL-OA-E-066 REV\# } 9 \\
\text { Instrument: Semi-Volatiles Manual }\end{array}$ \\
\hline \multicolumn{2}{|c|}{ Sample ID } & Prep Date & $\begin{array}{l}\text { Aliquot } \\
\text { (g) }\end{array}$ & $\begin{array}{l}\text { Prepped } \\
\text { Aliquot } \\
\text { (mI) }\end{array}$ & $\begin{array}{l}\text { Prepped } \\
\text { Factor } \\
(\mathbf{m I} / \mathrm{g})\end{array}$ & & & \\
\hline \multicolumn{2}{|c|}{$1204704080 \mathrm{MB}$} & 30-NOV-2020 10:33:00 & 30.43 & 1 & 0.03286 & & & \\
\hline \multicolumn{2}{|c|}{$1204704081 \mathrm{LCS}$} & 30-NOV-2020 10:33:00 & 30.04 & 1 & 0.03329 & & & \\
\hline \multicolumn{2}{|c|}{527597001} & 30-NOV-2020 10:33:00 & 30.04 & 1 & 0.03329 & & & \\
\hline \multirow{3}{*}{\multicolumn{2}{|c|}{$\begin{array}{l}1204704082 \mathrm{MS} \\
(527597001) \\
1204704083 \mathrm{MSD} \\
(527597001) \\
527597002\end{array}$}} & 30-NOV-2020 10:33:00 & 30.12 & 1 & 0.0332 & & & \\
\hline & & 30-NOV-2020 10:33:00 & 30.27 & 1 & 0.03304 & & & \\
\hline & & 30-NOV-2020 10:33:00 & 30.25 & 1 & 0.03306 & & & \\
\hline \multicolumn{2}{|c|}{527597003} & 30-NOV-2020 10:33:00 & 30.18 & 1 & 0.03313 & & & \\
\hline \multicolumn{2}{|c|}{527597004} & 30-NOV-2020 10:33:00 & 30.12 & 1 & 0.03287 & & & \\
\hline \multicolumn{2}{|c|}{527597005} & 30-NOV-2020 10:33:00 & 30.17 & 1 & 0.03315 & & & \\
\hline \multicolumn{2}{|c|}{527597006} & 30-NOV-2020 10:33:00 & 30.1 & 1 & 0.03322 & & & \\
\hline \multicolumn{2}{|c|}{527597010} & 30-NOV-2020 10:33:00 & 30.39 & 1 & 0.03291 & & & \\
\hline \multicolumn{2}{|c|}{527597013} & 30-NOV-2020 10:33:00 & 30.8 & 1 & 0.03247 & & & \\
\hline \multicolumn{2}{|c|}{527597011} & 30-NOV-2020 10:33:00 & 30.15 & 1 & 0.03281 & & & \\
\hline \multicolumn{2}{|c|}{527597015} & 30-NOV-2020 10:33:00 & 30.52 & 1 & 0.03277 & & & \\
\hline \multicolumn{2}{|c|}{527597016} & 30-NOV-2020 10:33:00 & 30.35 & 1 & 0.03295 & & & \\
\hline \multicolumn{2}{|c|}{528429002} & 30-NOV-2020 10:33:00 & 30.27 & 1 & 0.03304 & & & \\
\hline \multicolumn{2}{|c|}{528429003} & 30-NOV-2020 10:33:00 & 30.07 & 1 & 0.03326 & & & \\
\hline \multicolumn{2}{|c|}{528429004} & 30-NOV-2020 10:33:00 & 30.19 & 1 & 0.03312 & & & \\
\hline \multicolumn{2}{|c|}{528429005} & 30-NOV-2020 10:33:00 & 30.13 & 1 & 0.03319 & & & \\
\hline \multicolumn{2}{|c|}{528429006} & 30-NOV-2020 10:33:00 & 30.33 & 1 & 0.03297 & & & \\
\hline Type & Sample Id & Description & & & Serial Number & Spike Amt & Units & Comments: \\
\hline I.cs & 1204704081 & PAH STM T.CS 10 mg.T. & & & WF200918-20 & 1 & $\mathrm{mI}$ & \multirow{2}{*}{ Soxtherm Lnit:: 7A, 8A, 9A, 10A } \\
\hline MS & 1204704082 & PAH SIM LCS $10 \mathrm{mgLL}$ & & & WE200918-20 & 1 & $\mathrm{~mL}$ & \\
\hline MSD & 1204704083 & PAH SDM LCS $10 \mathrm{mgI}$ & & & WE200918-20 & 1 & $\mathrm{~mL}$ & Start Time:: 1051 \\
\hline SURR & All & BNASIMSURR & & & WE201015-77 & 1 & $\mathrm{~mL}$ & End Time:: 1153 \\
\hline REGNI & All & Sand pure 40-100 mesh & & & $3116121 \cdot \mathrm{A}$ & 30 & $\mathrm{~g}$ & Verified by $\mathrm{CB}$ \\
\hline REGNT & All & Methylene Chloride & & & 3138096 & 60 & $\mathrm{~mL}$ & \\
\hline REGNT & All & Acctone & & & $3140994-\mathrm{B} 4$ & 60 & $\mathrm{~mL}$ & \\
\hline
\end{tabular}


Prep Logbook

Extraction of Semivolatile and Nonvolatile Organic Compounds from Groundwater, Wastewater, and Other Aqueous Samples

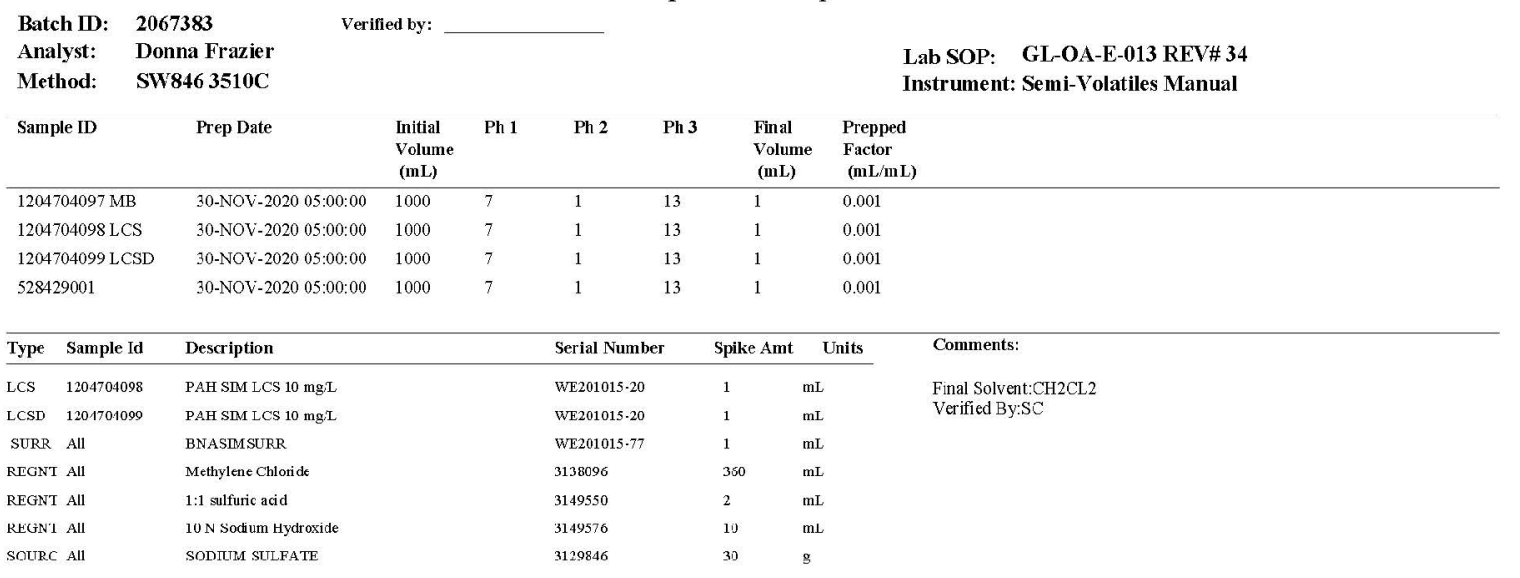




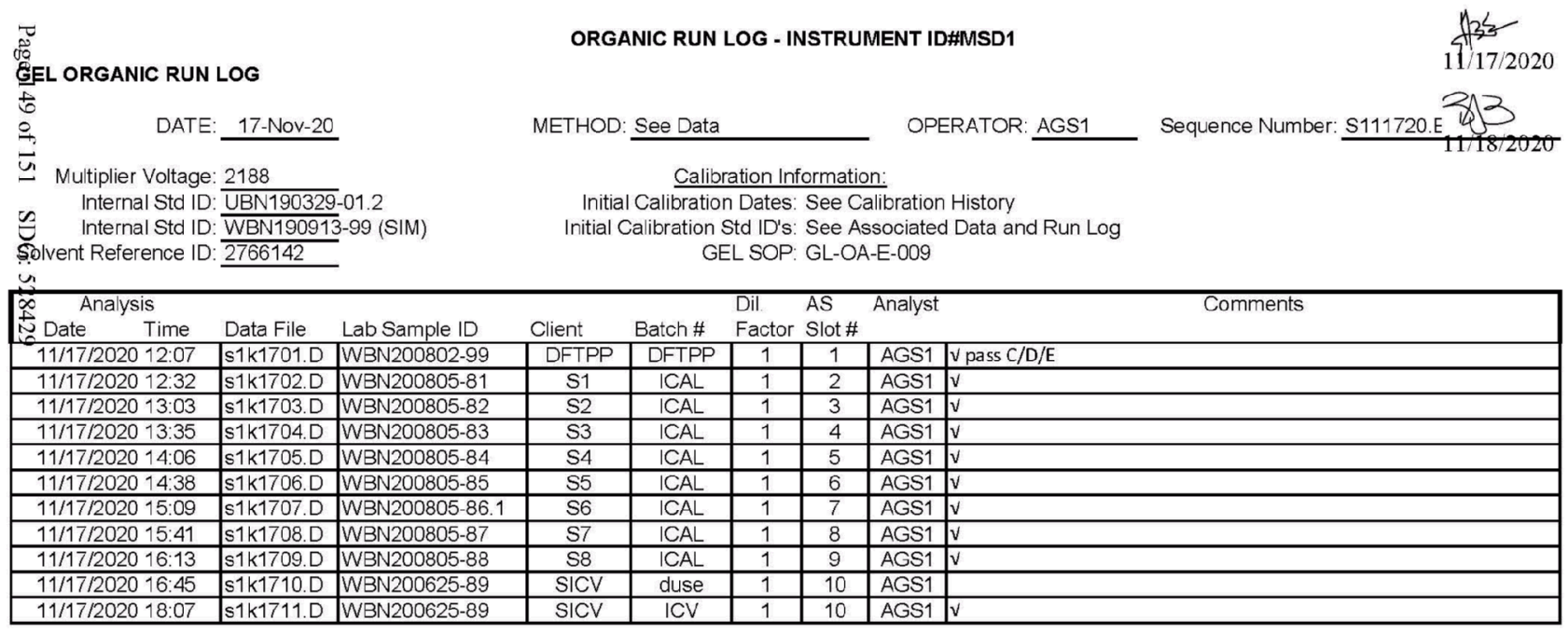




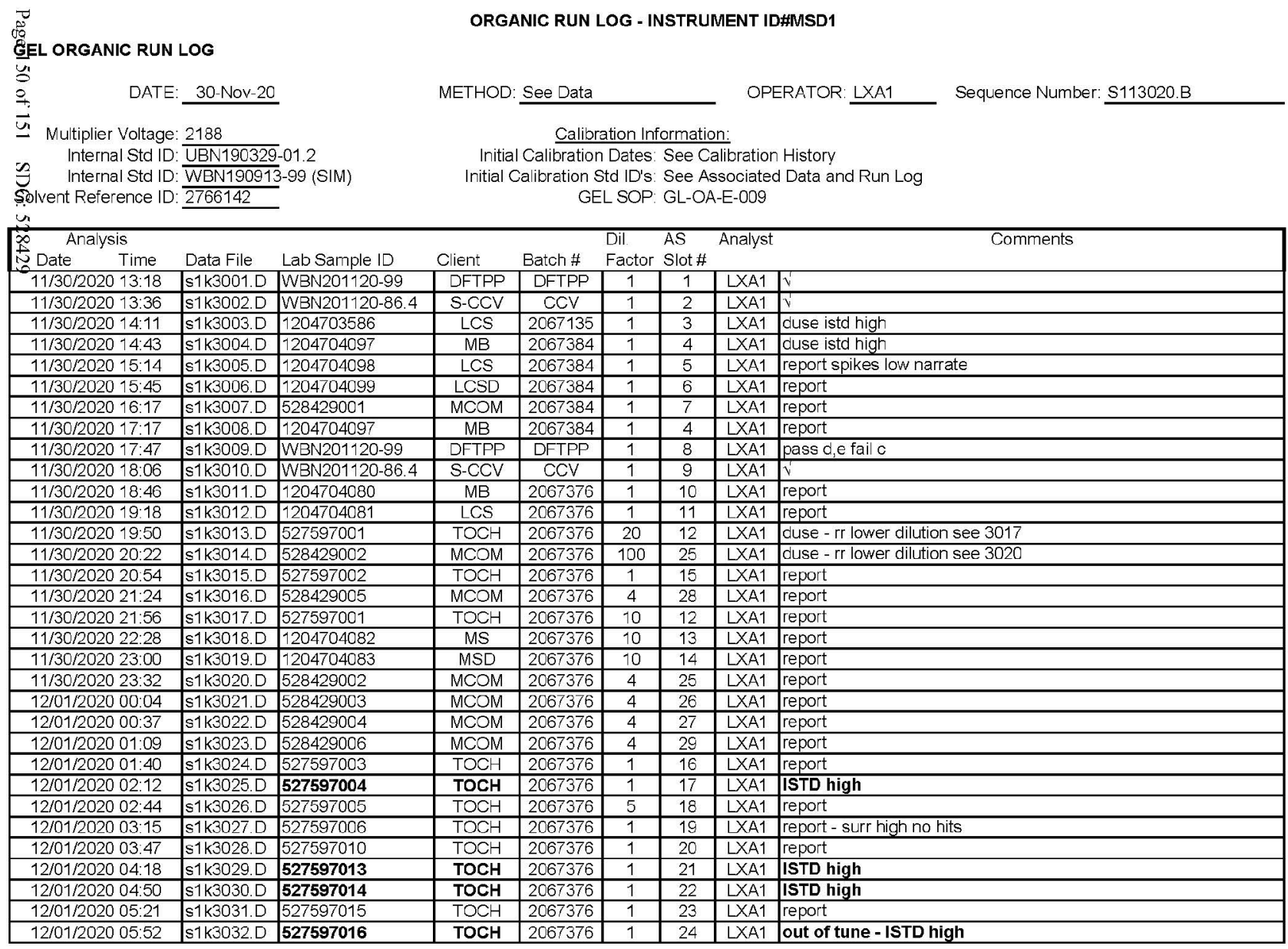




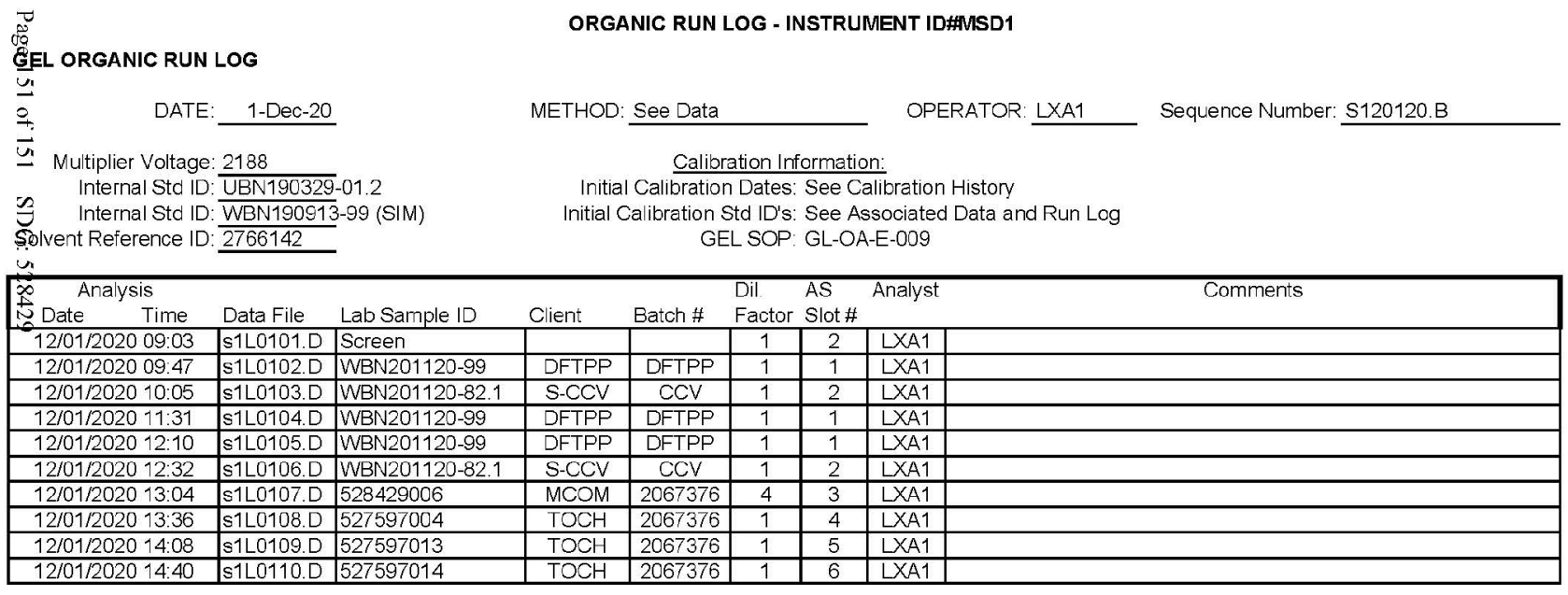




\section{Appendix F \\ Idaho Risk Evaluation Manual for Petroleum \\ Releases}

\section{Idaho \\ Risk Evaluation Manual for Petroleum Releases}

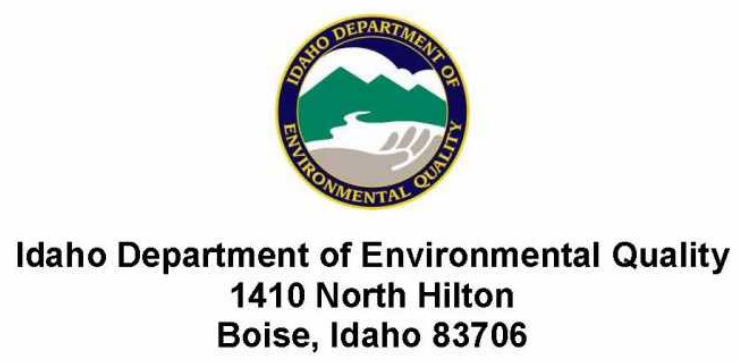

August 2012 
Table 2 lists the screening levels for unrestricted use. For comparison, Table 2 provides the riskbased concentrations in soil and groundwater for all the pathways and ROE listed above. The screening level values incorporated in the Rule are indicated in bold.

Because of the methods and assumptions used in the development of the screening levels and the current limitations of laboratory analytical methods, the calculated screening levels may be lower than the practical quantitation limit reported by a laboratory for selected chemicals. In these situations, site-specific review by DEQ will be required based on the criteria provided in Section 500 of the Rule and Appendix K.

Table 2. Screening Level Concentrations for Soil, Groundwater, and Soil Vapor

\begin{tabular}{|c|c|c|c|c|c|c|c|}
\hline \multirow[b]{3}{*}{ CHEMICAL } & \multicolumn{3}{|c|}{$\begin{array}{c}\text { SOIL } \\
(\mathrm{mg} / \mathrm{kg})\end{array}$} & \multicolumn{2}{|c|}{$\begin{array}{l}\text { GROUNDWATER } \\
\text { (mg/L) }\end{array}$} & \multicolumn{2}{|c|}{$\begin{array}{c}\text { DEEP SOIL VAPOR } \\
\text { (ug/m3) } \\
\text { (>3-5 feet bgs) }\end{array}$} \\
\hline & & & & & & \multirow{2}{*}{$\begin{array}{c}\text { Unrestricted } \\
\text { Use } \\
\text { Vapor } \\
\text { Intrusion } \\
\end{array}$} & \multirow{2}{*}{$\begin{array}{c}\begin{array}{c}\text { Commercial/ } \\
\text { Industrial }\end{array} \\
\text { Vapor } \\
\text { Intrusion }\end{array}$} \\
\hline & $\begin{array}{c}\text { Vapor } \\
\text { Intrusion }\end{array}$ & $\begin{array}{c}\text { Direct } \\
\text { Contact }\end{array}$ & $\begin{array}{c}\text { Groundwater } \\
\text { Protection }\end{array}$ & $\begin{array}{l}\text { Vapor } \\
\text { Intrusion }\end{array}$ & Ingestion & & \\
\hline Benzene & 0.08 & 8.3 & $\begin{array}{r}0.025 \\
\end{array}$ & 0.044 & 0.005 & 31 & 160 \\
\hline Toluene & 1300 & 7930 & 6.6 & 340 & 1 & 520000 & 2200000 \\
\hline Ethylbenzene & 0.25 & 39 & 7.4 & 0.05 & 0.700 & 97 & 490 \\
\hline Xylenes & 27 & 6170 & 91 & 8.7 & 10 & 10000 & 44000 \\
\hline Naphthalene & 0.12 & 44 & 9.2 & 0.07 & 0.73 & 7 & 36 \\
\hline MTBE & 2.4 & 340 & 0.08 & 6.8 & 0.04 & 940 & 4700 \\
\hline 1,2-Dichloroethane & 0.02 & 3.7 & 0.013 & 0.03 & 0.005 & 9 & 47 \\
\hline Ethylene Dibromide & 0.001 & 0.27 & 0.00014 & 0.004 & 0.00005 & 0.4 & 2 \\
\hline Acenaphthene & NA & 4470 & 200 & NA & 2.2 & NA & NA \\
\hline Anthracene & NA & 22300 & 3200 & NA & 11 & NA & NA \\
\hline Benz(a)anthracene & NA & 0.19 & 0.09 & NA & 0.00003 & NA & NA \\
\hline Benzo(a)pyrene & NA & 0.02 & 2.1 & NA & 0.0002 & NA & NA \\
\hline Benzo(b)fluoranthene & NA & 0.19 & 0.31 & NA & 0.00003 & NA & NA \\
\hline Benzo(k)fluoranthene & NA & 1.9 & 3.1 & NA & 0.0003 & NA & NA \\
\hline Chrysene & NA & 19 & 9.5 & NA & 0.003 & NA & NA \\
\hline Fluoranthene & NA & 2970 & 1400 & NA & 1.5 & NA & NA \\
\hline Fluorene & NA & 2970 & 240 & NA & 1.5 & NA & NA \\
\hline Pyrene & NA & 2230 & 1000 & NA & 1.1 & NA & NA \\
\hline
\end{tabular}

Values in bold are current screening level values specified in the Rule. Screening level values for deep soil vapor are equivalent to EPA Regional Screening Levels (EPA, 2012) for residential and industrial ambient air divided by an attenuation factor of 0.01 . NA: not applicable because the chemical does not meet EPA volatility criteria or does not have a Regional Screening Level for ambient air. 